University of Rhode Island

DigitalCommons@URI

Open Access Master's Theses

2002

\title{
ASSESSMENT OF THE FUTURE OFFICE NEEDS OF THE INTERNATIONAL COMMUNITY
}

Lisa K. Ohmann

University of Rhode Island

Follow this and additional works at: https://digitalcommons.uri.edu/theses

\section{Recommended Citation}

Ohmann, Lisa K., "ASSESSMENT OF THE FUTURE OFFICE NEEDS OF THE INTERNATIONAL COMMUNITY" (2002). Open Access Master's Theses. Paper 415.

https://digitalcommons.uri.edu/theses/415

This Thesis is brought to you for free and open access by DigitalCommons@URI. It has been accepted for inclusion in Open Access Master's Theses by an authorized administrator of DigitalCommons@URI. For more information, please contact digitalcommons-group@uri.edu. 


\title{
ASSESSMENT OF THE FUTURE OFFICE NEEDS OF \\ THE INTERNATIONAL COMMUNITY
}

\author{
BY \\ LISA K. OHMANN \\ A RESEARCH PROJECT SUBMITTED IN \\ PARTIAL FULFILLMENT OF THE REQUIREMENTS \\ FOR THE DEGREE OF MASTER OF \\ COMMUNITY PLANNING
}

UNIVERSITY OF RHODE ISLAND

2002 


\title{
MASTER OF COMMUNITY PLANNING
}

\section{RESEARCH PROJECT}

OF

\author{
LISA K. OHMANN
}

Approved:

Major Professor

Acknowledged:

Director

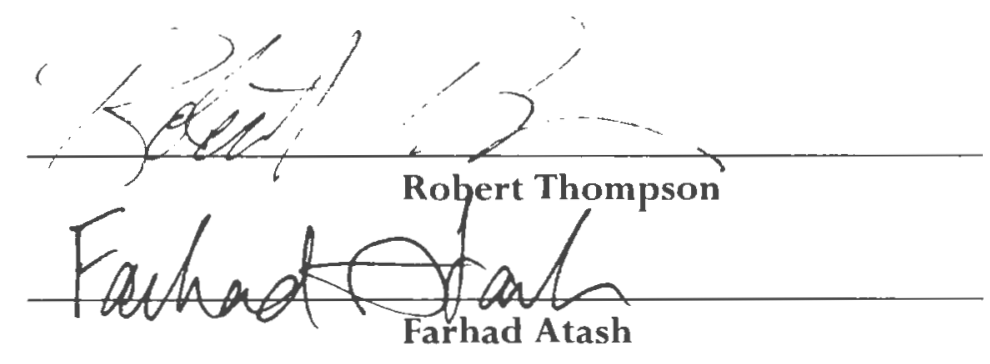




\section{FOREWARD}

\section{Client:}

There are 59 Community Boards in New York City, each one representing a specific local district (or community) within one of the five boroughs of Manhattan. Each Board is comprised of up to 50 volunteer members, who serve as a local review board for proposed projects within their respective district and make recommendations on a wide range of land use, zoning, budget, and local planning issues. In addition, a Community Board monitors traffic and transportation issues, capital projects in parks, the concerns of seniors and youth, economic development, and public safety. Essentially, a Community Board serves as a liaison between residents within the area, City, State and federal elected officials, community groups, and other City agencies on numerous issues.

Manhattan Community Board \#6 (CB6) represents the East Side of Midtown Manhattan. It's borders are roughly from East $14^{\text {th }}$ Street (southern border) to East $59^{\text {th }}$ Street (northern border) and from Lexington Avenue (western border) to the East River (eastern border). It also includes a small area from East $34^{\text {th }}$ street (southern border) to East $40^{\text {th }}$ street (northern border) and from Madison Avenue (western border) to the East River(eastern border).

Since the establishment of the United Nations Headquarter's seat in the early 1950's, Manhattan CB6 has been concerned with increasing demands of commercial office space needs by UN-related uses, including permanent missions to the UN, nongovernmental organizations, UN specialized agencies, UN programmes and funds, as well the UN Secretariat. This long-range planning study of the spatial needs of the UN System and its permanent missions, as well as consular corps in New York City is being conducted in response to the apparent increasing demand for cormmercial office space associated with the international community along the east side of Midtown Manhattan.

\section{Purpose:}

The purpose of the study is to: (a) identify the past and present spatial trends and forecast longterm future office space needs of the international community; (b) quantify the ability of the Turtle Bay, Kips Bay, and Murray Hill neighborhoods, as well as the rest of Manhattan CB6 to accommodate the international community's current and projected future office space demand; and (c) help develop recommendations and a long-term plan to continue to meet the needs of the international community in New York City. Furthermore, the study aimed to provide CB6 with a better understanding of the UN and the international community, and their effects on the area represented by CB6. 


\title{
ASSESSMENT OF THE FUTURE OFFICE SPACE NEEDS OF THE INTERNATIONAL COMMUNITY
}

\author{
Table of Contents
}

Page Number

EXECUTIVE SUMMARY

$S-1$

TASK 1: INTRODUCTION AND OVERVIEW OF THE UN SYSTEM, PERMANENT MISSIONS, AND CONSULAR USES

I. Background

II. United Nations Organization Structure

A. Six Main Organs of the United Nations

B. The UIN Programs and Funds

C. The UN Specialized Agencies

III. History of the United Nations Headquarters in New York

A. Site Selection and Ker Design Features

B. The Present Buildings of the UN Headquarters

C. Unitcd Nations System's Space Utilization

IV. Employment in the Linited Nations

A. Current Management Trends Affecting Employment

V. Non-governmental Organizations 
VII. Intcrnational Treaty Obligations

TASK 2: $\quad$ ASSESSMENT OF LAND USE, ZONING, AND NEIGHBORHOOD CHARACTER IN THE STUDY AREA

I. Introduction $2-1$

II. Background-Historic Land Uss $\quad \underline{2}-1$

III. Existing Conditions 22

A. Mcthodology

B. Land Use

C. Zoning

D. Neighborhood Character

E. Transportation

IV. Land Use Forecasts- A Look Ahead $\quad 2-13$

Task 3 ASSESSMENT OF COMMERCIAL REAL ESTATE CONDITIONS IN MANHATTAN COMMUNITY BOARD 6

I. Introduction $3-1$

II. Background-Commercial Office Space in Manhattan 3-1

III. Historic Review of Midtown Manhattan's Commercial Office Market 33

A. The Midtown Office Market in the 1980's

B. The Midtown Oflice Market in the 1990's

IV. An Overview of Existing 2001 Commercial Office Real Estate Conditions in New York City

A. The Manhattan Office Market

V. Commercial Office Market Conditions in Community Board 6

A. The Plaza Submarket

B. The Grand Central/Midtown East Submarket

C. The LIN Plaza Submarket

D. The Murray Hill Submarket

E. The Gramercy Park Submarket

V1. Pattern of Comnercial ()ffice Space Utilization Typical of the International 
Community in New York City

A. The United Nations, Specialized Agencies, and Programmes and Funds

B. Permanent Missions

C. Foreign Consulates

D. Civil Socicty. Non-governmental Organizations (NGO's)

VII. Snapshot of Commercial Space Arailability

A. Potential Sites for New Construction

B. Building Rental/ Acquisition Opportunities

TASK 4 ASSESSMENT OF THE FUTURE OFFICE SPACE NEEDS OF THE UN SYSTEM, PERMANENT MISSIONS, AND CONSULAR CORPS

I. Introduction

A. The United Nations Secretariat Staff

B. The United Nations Specialized Agencies and Programmes and Funds in NYC

C. The United Nations Patterns of Space Utilization

II. The United Nations Emplorment Trends and Space Utilization

A. Member States Represcntation in New York City 1977-2000

B. Employment within Permanent Missions

C. Permanent Missions Patterns of Space Utilization

III. Permanent Mission Employment Trends and Space Utilization

A. Consular Representation in New York City-1980-2000

B. Employment within Forcign Consulates

C. Forcign Consulates Patterns of Space Utilizatiom

IV. Forcign Consulate Fmployment Trends and Space Utilization $\quad 4-20$

V. Conclusions and Recommendations $\quad+3$ I

\section{APPENDIX A}

Inventory of Arailable Office Space in Manhattan Office Markets as of December 2001

\section{APPENDIX B}

Inventory of Arailable Office Space in Manhattan Community Board 6

\section{APPENDIX C}

Summary of Commercial Office Space Rented by the UIN System in New York City 


\section{APPENDIX D}

Available Office Space in the Vicinity of the United Nations

\section{ASSESSMENT OF THE FUTURE OFFICE SPACE NEEDS OF THE UN SYSTEM, PERMANENT MISSIONS, AND CONSULAR CORPS}

\section{List of Tables}

Page Number

11 Membership of the UN $\quad 19$

1-2 The United Nations Srstem Emplornent Statistics $1-10$

2-1 General Population Characteristics of Community Board 6 as Compared to New York City and the Borough of Manhattan 는

2-2 Housing Characteristics of Community Board 6

2-3 Land Use Percentages in Community Board 6 25

2-4 Zoning Designations in the Study. Area 2-5*

2-5 Public Transit Facilities within Community Board $6 \quad$ 2-12*

2-6 Recent Derelopment Proposals in Community Board $6 \quad 2-15$

3.1 The Midtown Office Market in the 1980's 3.3

3.2 The Midtown Office Market in the Larly 1990's 35

3-3 Inventory of Arailable Commercial Office Space in Manlattan P'rior to 9/11 3-8

$3+$ Inventorr of Arailable Office Space in the Manhattan Office Markets Prior to $9 / 11$

3-5 Real Estate Markets in Community Board 62001 Conditions 3.13

3-6 Inventory of Available Office Space in the Plaza Submarket 3-1t 
3-7 Inventory of Available Office Space in the Grand Central Submarket $3-16$

3-8 Inventory of Available Office Space in the UN Plaza Submarket 317

3-9 Inventory of Available Office Space in the Murray Hill Submarket $3-18$

3-10 Inventory of Available Office Space in the Gramerey Park Submarket $\quad 320$

3-11 Existing Buildings on the UN Headquarters Campus $\quad 323$

3-12 Office Space Leased by the UN Sistem in Midtown 3-24

313 Administratice Oflices of UN Programmes and Funds in Midtown 325

3-14 Permanent Missions Referenced by Manhattan Community Board 3-26

3-15 Permanent Missions in Community Board 6- Referenced by Neighborhood 3-26

316 Permancnt Missions Referenced by Manhattan Office Markets $\quad 327$

3-17 Permanent Missions that Could be in the Market for Commercial Office Space in the Next Five Years $\quad 3.28$

3-18 Permanent Observer Missions Referenced by Manhattan Community Board 329

3-19 Forcign Consulates Referenced by Manhattan Community Board 3-30

3-20) Forcign Consulates in Community Board 6-Referenced by Neighborhood 3-30

3-21 Forcign Consulates Referenced by Manhattan Office Markets 3.31

322 Foreign Consulates that Could be in the Market for Commercial Office Space

3-23 Potential Sites for New Office Construction $3-35$

3-24 A Highlighted Sample of Arailable Office Space in the Vicinity of the United

4-1 Peacekeping Operations of the UIN 1948-2000

4-2 Member Grow th in the LInited Nations 1977-2000 +-10

43 Forecast of Member Growth in New York City +12 
4-4 Permanent Missions' Employment Grow th in New York City

45 Permanent Missions to the UN Referenced by Manhattan Community Board 1980-2001

4-6 Permanent Missions to the UN in Community Board 6 Referenced by Neighborhood-1980-2001

4-7 Percentage of Permanent Mission Space Owned or Leased by a UN Member State 4-17

4-8 Permanent Missions to the UN Referenced by Manhattan Office Markets 1980-2001

4-9 Projected Square Fect of New Mission Space in Manhattan

410 Permanent Mission Office Space Refereneed by Community Board in 2010 and 2020

4-11 Growth in Forcign Consulates in Manhattan-1977-2001 4-21

+12 Consular Uses that Left New York City During the 1980's +21

4-13 Forecast of Consular Growth in New York City 4 4-23

4-14 Forcign Consulatc's Emplovment Growth in Manhattan $\quad$ +-24

415 Forcign Consulates Referenced by Manhattan Community Board 19802001

4-16 Foreign Consulates in Community Board 6-Referenced by Neighborhood

4-17 Percentage of Foreign Consulates Ow ned or Leased by a Forcign Government $\quad$ 4-27

4-18 Forcign Consulates Referenced by Manhattan Office Markets $199802001 \quad+28$

4-19 Project Square Feet of New Consular Office Space in Manhattan 4-29

4-20 Forcign Consulate Space Referenced by Community Board in 2010 and 2020

4.21 Existing Conditions and Projected Conmercial Office Space Needs of the International Community in Manhattan in 2010 and 2020

4-22 Existing Conditions and Projected Commercial Office Space Needs of the Intcrnational Community in Manhattan in 2010 and $2020 \quad+33$

4.23 Available Office Space in Community Board $6 \quad 433$ 
* Table comes after page listed.

\section{List of Figures}

Following Page

S-1 Study Area Map $\quad S-1$

11 The United Nations Sistem Organizational Chart $\quad 12$

1-2 United Nations Headquarters Campus 16

1-3 View of the Secretariat, Conference, Gencral Asscmbls, and UINITAR Buildings $\quad 17$

$\begin{array}{lll}1-4 & \text { UN Secretariat Building } & 17\end{array}$

1-5 View of the Secretariat, Conference, 1)ag Hammarskjold Library, South Annex and the General Assembly Buildings $1-7$

1-6 View of the Dag Hammarskjold Library, Secretariat, and General Assembly Buildings

17 View of the General Assembly Hall $\quad 1.7$

1-8 View of the Trustceship Council Chambers 1.8

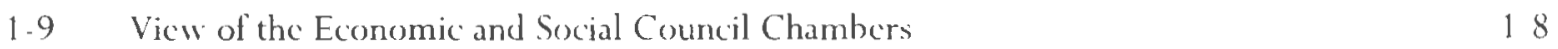

110 United Nations Decelopment District $\quad 1-9$

1-11 View of One and Two LIN Plaza

2-1 Study Arca 21

2-2 Map of All the Neighborhoods and Residential Development in Community District 6

2-3 Study Arca Map (Primary and General Study Areas) 2-3 
2-4 Primary Study Arca Land Use Map for $1980 \quad 2-4$

2-5 Primary Study Arca Land Usc Map for $1990 \quad 2-4$

2.6 Primary Study Arca Land Use Map for $2000 \quad 24$

2-7 Zoning Districts within the Primary and General Study Areas 2-5

2-8 Special Midtown District and Grand Central Subdistrict $\quad 2-7$

2-9 New York City Transit Local Bus Routes within Community Board Six $\quad 2-13$

3-1 Map of the Major Commercial Office Markets in Manhattan 39

3-2 Map of the Commercial Office Submarkets in Manhattan 3-9

33 Map of the Commercial Office Submarkets in Community Board 6

$3+$ Study Area of the Urbitran Associates' 1998 Commercial Space Availability

3-5 Zoning Districts within the Immediate Vicinity of the UN Headquarters Campus $\quad 33+$

36 Potential Development Sites within the Imnediate Vicinity of the UIN Headquarters Campus $\quad 334$

3-7 Former ConEdison Sites $\quad 3.36$

4-1 Completed and Ongoing Peacekecping Missions $\quad+3$

4-2 Ongoing Pcacekccping Missions $\quad$ +-3

4-3 UN Secretariat Stafling Levels at IIN Headquarters $\quad$ + +*

* Actual Page Number 


\section{OVERVIEW}

The United Nations Headquarters campus, occupying approximately 18 -acres above the Franklin D. Roosevelt Drive on the east side of Midtown Manhattan, is a major economic, social, and physical presence in the City of New York, particularly within the surrounding communities of Turtle Bay, Murray Hill, and Kips Bay (see Figure S-1). Five of the United Nations' (UN) main bodies, including the UN Secretariat, are headquartered in New York City, and several of the UN's specialized agencies, and programmes and funds, such as the United Nations Development Program (UNDP) and the United Nations International Children's Emergency Fund (UNICEF), maintain headquarter offices in New York City. Almost all of the UN's member states and observer entities also maintain offices in New York City. In addition, numerous non-governmental organizations (NGO's) affiliated with the UN are located within the New York City Metropolitan Area. As New York City is a world city and a significant part of the global economy, numerous foreign states have also established consular offices in Manhattan.

The presence of the UN System extends from the UN Headquarters campus, located roughly at the termini of East $44^{\text {th }}$ and East $49^{\text {th }}$ streets, to many of the residential and commercial streets of eastern Midtown between East $34^{\text {th }}$ and East $53^{\text {rd }}$ streets which are home to almost all of the UN's specialized agencies, UN programmes and funds, the majority of permanent missions to the UN, several NGO's, as well as many foreign consular uses. A substantial portion of the total floor area occupied by the UN and its associated uses and permanent missions, as well as consular offices, are concentrated in Manhattan Community Board 6 (CB6), and are therefore a strong influence on the neighborhood characteristics and real estate conditions in the area.

As long as the UN Headquarters remains at its current New York City location, the actions of the UN and its missions (in terms of space planning needs) will continue to be a defining characteristic of the surrounding community. This long-range planning study of the spatial needs of the UN System and its permanent missions, as well as consular corps in New York City is being conducted in response to the apparent increasing demand for commercial office space associated with the international community. The purpose of the study is to: (a) identify the past and present spatial trends and forecast long-term future office space needs of the international community; (b) quantify the ability of the Turtle Bay, Kips Bay, and Murray Hill neighborhoods, as well as the rest of Manhattan CB6 to accommodate the international community's current and projected future office space demand; and (c) help develop recommendations and a long-term plan to continue to meet the needs of the international community in New York City. 
Project Area Map

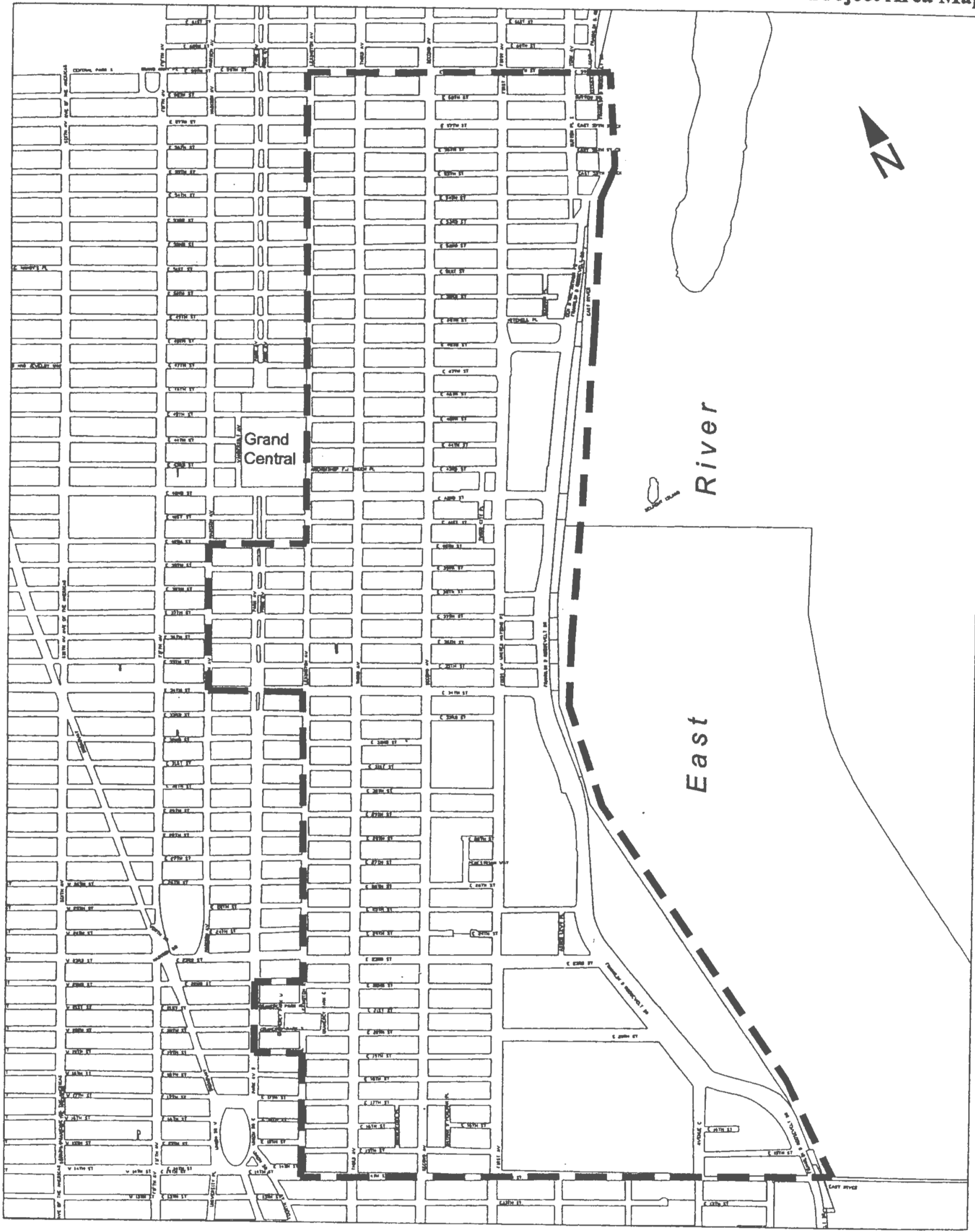




\section{TASK I: INTRODUCTION AND OVERVIEW OF THE UNITED NATIONS SYSTEM, PERMANENT MISSIONS, AND CONSULAR USES}

The United Nations (UN) officially came into existence in October 1945, when the United Nations Charter was ratified by 51 nations from around the world. These countries committed to preserving peace through international cooperation and collective security. Today, with a current total membership of 189 countries, nearly every nation in the world belongs to the UN.

The UN Headquarters seat is located along the eastern edge of Midtown Manhattan, on the banks of the East River. It is bound by East $48^{\text {th }}$ Street to the north, the East River to the east, East $42^{\text {ad }}$ Street to the south, and UN Plaza (First Avenue) to the west. As the site is a relatively small property, the UN Headquarters seat is a park-like campus stretching from First Avenue to the East River's edge with one tall building accommodating the UN's tremendous office space demand. Currently, there are six buildings that stand within the UN Headquarter campus including the Secretariat building, the General Assembly building, the Conference building, the Dag Hammarskjold library, the North Lawn building, and the South Annex.

The UN is a sophisticated network of organizations that perform a range of duties that affect global relations and provide an invaluable forum through which nations can resolve differences and implement shared objectives. The entire UN System consists of three major components including, (1) the UN, (2) UN programmes and funds, and (3) UN's specialized agencies. The principal organs of the UN System are the six main bodies that comprise the UN. Five of these main bodies, including the General Assembly, the Security Council, the Economic and Social Council, the Trusteeship Council, and the Secretariat, are headquartered in New York City and make up the core of the New York City international community. The UN's specialized agencies and UN programmes and funds are a diverse group of international organizations that have focused missions and interests in a vast range of areas. They work with the General Assembly and the Economic and Social Council to promote and implement the shared goals and policies of the UN System. Several of the UN's most renowned specialized agencies, and programmes and funds are headquartered in New York City.

Permanent missions and consular uses are separate entities from the UN System. Although part of the New York City international community, they represent and serve the interests of foreign nations within the United States. Missions are the UN member states' business offices (or embassies) to the UN, while consular uses serve as the official representation of foreign states within New York City. Currently, New York City serves as host to 187 permanent missions (186 in Manhattan) and 99 consular uses. Almost all of the permanent missions and many of the consular uses are concentrated along the east side of Midtown in CB6.

Non-governmental organizations (NGO's) are nonprofit, diverse voluntary citizens' groups that serve as grassroots advocates for the UN System. They are task-oriented and driven organizations with a common interest, that bring attention to citizens' issues, monitor policy, and encourage political participation at the community level. Currently, the New York City Metropolitan Area serves as host to more than a thousand NGO's. However, less than 200 NGO's have commercial office facilities in Manhattan. 


\section{TASK II: ASSESSMENT OF LAND USE, ZONING, AND NEIGHBORHOOD CHARACTER IN}

THE STUDY AREA

Manhattan Community Board 6 (CB6) is a densely populated, mixed-use area that serves as the home to numerous office, commercial, institutional, and residential uses. Covering more than 875 -acres, CB6 lines most of the eastern edge of Midtown from East $59^{\text {b }}$ Street to East $14^{\text {th }}$ Street, from Lexington Avenue to the East River, as well as a small area between East $40^{\text {bh }}$ and East $34^{\text {th }}$ streets from Madison Avenue to the East River and a small are between East $22^{\text {ad }}$ and East $19^{\text {th }}$ streets from Park Avenue South to the East River. Overall, this area of Midtown is generally less developed than the commercial core of Midtown, and is largely defined by its distinct residential neighborhoods and large institutional uses. Within this area there is a range of neighborhoods and districts, each with its own unique character, including the residential neighborhoods of Turtle Bay, the Sutton Area Community (SAC), Murray Hill, Tudor City, Rose Hill, Kips Bay, Gramercy Park, Stuyvesant Square, Stuyvesant Town, and the Peter Cooper Village, and the commercial corridors of Lexington and Third avenues, and East $42^{\text {nd }}$ and East $34^{\text {th }}$ streets.

Generally, commercial, retail, hotel and office uses, and moderate to high-density commercial (C1-9, C2-8, C5-2, and C6-6) zoning districts are concentrated inland towards the center of Manhattan, and line the Lexington and Third Avenue and East $42^{\text {nd }}$ Street corridors. Residential uses and moderate to high-density residential (R-7, R-8, and R-10) zoning districts are located closer to the East River between First and Second avenues lining cross-town streets. Institutional and public facility uses, including the UN System, permanent missions, and consular uses, however, are scattered throughout much of CB6. Very few industrial areas and vacant parcels are located within CB6. The largest remaining industrial sites (the former Con Edison sites), situated along the East River between East $35^{\mathrm{b}}$ and East $41^{\mathrm{s}}$ streets, are expected to be developed into office/residential uses in the near future pursuant to a zoning change.

CB6 also contains the Special United Nations Development District. Located directly west of the UN Headquarters campus, the United Nations Development District was created to preserve and promote the City of New York as a center for international organizations and as an office headquarters, as well as a cosmopolitan residential community. Through encouraging the development of suitable office, meeting, and conference facilities, hotel accommodations, and housing for the UN System, permanent missions, and related NGO's in the immediate vicinity of the UN Headquarters campus, this special overlay district is designed to promote the coordinated redevelopment of the area adjacent to the UN Headquarters campus, and assure the retention of the UN Headquarters in New York City.

As there is very minimal vacant commercial space and no current plans for zoning changes in CB6, the commercial space demands of local companies and institutions are extremely limited in CB6 without major site redevelopment. Currently, CB6 is experiencing some major development opportunities. Among them, is the redevelopment of the Con Edison facilities. This prime river-front property is 9.2-acres, and is the largest tract of "undeveloped" land remaining in Midtown Manhattan. FMS East River Associates, LLC has signed a contract to purchase these properties and intends to develop the area into a mixed-use facility with retail, office, and residential uses. No detailed development plans or proposals, however, have been presented for this site at this time.

In addition, the UN Secretariat is evaluating options for renovating and upgrading its headquarters campus, and is currently in its schematic planning stage. It is anticipated that the UN Secretariat will require approximately $800,000 \mathrm{gsf}$ of office swing space during its proposed renovations to temporarily accommodate its staff while renovations are underway. 


\section{TASK III: ASSESSMENT OF COMMERCIAL REAL ESTATE CONDITIONS IN COMMUNITY BOARD 6}

CB6 is comprised of five office submarkets. The Midtown North office submarkets of Plaza, Grand Central, and UN Plaza, and the Midtown South office submarkets of Gramercy Park and Murray Hill are all entirely or partially included within CB6. In total, $\mathrm{CB} 6$ has a total office inventory of approximately 67 million square feet (about 17 percent of Manhattan's total office market). Approximately 8.2 percent (5.5 million square feet) of this office space was available prior to September 11, 2001. Most of CB6's office facilities are located within the northeastern portion of $\mathrm{CB} 6$ in the office submarkets of Plaza and Grand Central (approximately 82 percent) and more than half (approximately 58 percent) of CB6's available office facilities are concentrated in the Grand Central office submarket.

One of CB6's major commercial office tenants is the international community. Since the establishment of the UN Headquarters in New York City, the UN System has greatly expanded its membership, programs, and services. The UN Headquarters campus can no longer accommodate all of the UN Secretariat's various departments and all of the UN's specialized agencies and UN programmes and funds. To meet these increasing functions of the UN System, the UN presence in New York City has gone through periods of office expansion. However, the UN System has been able to minimize its demand for commercially (privately) leased office space in New York City through the assistance of the United Nations Development Corporation (UNDC), a state public benefit corporation, which was created to respond to the increasing needs and accommodations of the UN, its affiliated uses, and its member states. UNDC is mandated to formulate development plans for the coordinated development of the United Nations Development District and to provide advice and services with respect to real estate needs and development to the UN and its related uses in New York State. Since its establishment in 1968, UNDC has developed and operated approximately 1.8 million square feet of space in the vicinity of the UN Headquarters campus to be used by the UN and related entities.

As of August 2001, the entire UN System leased approximately 1.4 million square feet of Manhattan office space in CB6. Almost half of this leased space is occupied by the UN Secretariat, while the remainder serves the UN's specialized agencies and UN programmes and funds. More than 58 percent (approximately $819,000 \mathrm{sf}$ ) of this leased space is owned by UNDC and less than 42 percent (approximately 582,000 sf) is privately owned (commercially leased).

The UN's membership has also greatly expanded over the years and most member states (187 of 191) have leased, bought, or developed commercial office space in Manhattan to accommodate perrnanent mission space. Although permanent missions possess the flexibility to locate anywhere within the City, the vast majority of permanent missions are concentrated near or adjacent to the UN Headquarters campus along the eastern side of Midtown in CB6. Approximately 83 percent (154) of permanent missions are currently located in CB6 and occupy approximately 1.61 million square feet of office space. Less than 3 percent (approx. 63,000 sf) of permanent mission office space in Manhattan is owned by UNDC.

As the UN System has grown and expanded its efforts, the UN's related NGO's have also diversified and expanded. Currently, there are approximately 200 NGO's in Manhattan. However, as affordable office space is severely limited in Midtown, less than 28 percent (55) of NGO's are located in CB6. Most of the NGO's that are located in CB6 occupy small, leased office facilities.

In addition, New York City also hosts the largest foreign consular community in the world. One-hundred foreign consular uses are located in the New York Metropolitan Area, 99 of which are in Manhattan. As consular 
uses are not directly affiliated within the UN, consular offices are slightly more dispersed throughout the City and are generally located farther away from UN Headquarters than the majority of permanent missions. However, many consular uses are located within the same office buildings or within the same general area as their respective country's mission to the UN. Approximately 63 percent (63) of foreign consular uses are currently located in CB6 and occupy approximately 690,000 sf of office space. The majority (86 percent) of consular office space in Manhattan is commercially leased.

As Midtown is one of the most densely developed urban neighborhoods and one of the most competitive office markets in the country, CB6 possesses very few potential development sites and a limited amount of available office facilities. Only seven major potential development sites and approximately 2.1 million square feet of available commercial office space are located in the immediate vicinity of the UN Headquarters campus. Most of the identified potential development sites are relatively small (less than 6,000 sf) and are not located adjacent to other sites that could be developed. In total, if all the identified sites were developed, 1.11 million square feet of commercial office space could be developed as-of-right under current zoning regulations. The three largest and most suitable potential development sites identified were the four former Con Edison properties. Office development on a portion of these four sites could potentially accommodate a significant amount of conference and meeting facilities for the UN Secretariat, new permanent mission space, and new consular space, NGO offices, and/or other UN-related uses.

\section{TASK IV: INTERNATIONAL COMMUNITY'S SPACE NEEDS ASSESSMENT FOR 2010 \& 2020- COMMERCIAL OFFICE SPACE}

Given the UN's zero-growth policy, the entire UN System within New York City is not expected to grow significantly by 2020. As most of the UN's specialized agencies and UN funds and programmes are anticipated to maintain existing staff levels in New York City, the UN System (including the UN Secretariat) is expected to continue to occupy approximately 1.4 million square feet of leased office space in Manhattan CB6. More than 58 percent (approximately 819,000 gsf) of this leased office space would continue to be owned by UNDC and approximately $582,000 \mathrm{gsf}$ (about 42 percent) would be commercially leased. However, the UN Secretariat is expected to lease, purchase, and/or construct approximately 800,000 gsf of office swing space in the near future to accommodate all of the UN Secretariat's staff during the UN Headquarter's proposed capital refurbishment of the Secretariat building.

Assuming that the utilization trends of permanent missions during the last twenty years will continue through the next two decades, the vast majority of the existing and projected UN member states are expected to occupy mission facilities in close proximity to the UN in CB6. If existing trends continue UN membership can be expected to increase by approximately 3-8 percent ( 5 to 10 missions) by 2010 , and approximately 6-16 percent (11 to 31 missions) by 2020 . The maximum amount of office space occupied by permanent missions in Manhattan is expected to be approximately 2.14 million square feet in 2010, and approximately 2.29 million square feet in 2020 an increase of about 130,000 sf and 280,000 sf, respectively, compared to current conditions. CB6 is expected to experience a 7 to 20 percent increase in the total number of UN member states maintaining mission offices in their community board. Approximately 2.1 to 2.3 million gross square feet of office space in CB6 is expected to be occupied by approximately 165 to 185 permanent missions in 2020.

Assuming that the utilization trends of foreign consular uses during the last twenty years will continue through the next two decades, the vast majority of the existing and projected foreign consulates are expected to occupy commercial office facilities within Midtown. As more than 48 percent of permanent missions do not have 
consular representation in New York City, the New York City consular community has the potential to expand significantly by 2020 . If existing trends continue, the Manhattan consulate community can be expected to grow by approximately 10 percent ( 10 consulates) by 2010, and approximately 20 percent ( 20 consulates) by 2020 . The maximum amount of office space occupied by foreign consular uses in Manhattan is expected to be approximately 1.33 million square feet in 2010 , and approximately 1.52 million square feet in 2020 an increase of about 182,000 sf and 367,000 sf, respectively, compared to current conditions. CB6 is expected to experience a 41 percent increase ( 26 consulates) in the total number of consular uses maintaining commercial offices in their community board. Approximately 1.52 million gross square feet of commercial office space in CB6 is expected to be occupied by approximately 89 ( 74 percent of) foreign consulates in 2020 .

Permanent missions, consular uses, the UN Secretariat and the remainder of the UN System are expected to occupy approximately 4.7 to 4.8 million square feet of commercial office space in Manhattan by 2010 and approximately 5.0 to 5.2 million square feet by 2020 , versus 3.7 million square feet of commercial office space occupied by the international community today. If current utilization trends continue, the majority of the projected office space for the international community is expected to be accommodated by office facilities in CB6 and CB8. In addition, some of the existing consular uses in CB5 are anticipated to relocate to CB6 or CB8. The maximum amount of commercial office space occupied by the UN System, permanent missions, and/or foreign consular uses in CB6 is expected to be approximately 4.01 million square feet in 2010, and approximately 1.13 million square feet in 2020.

\section{Conclusions}

Currently the international community occupies approximately 4.2 percent (approximately 2,882,000 sf) of the entire CB6 commercial real estate market. If the international community continues to maintain its existing growth rate and exhibits similar utilization trends to the 1980's and 1990's, the international community can be expected to occupy approximately 5.9 percent of the commercial real estate market in CB6 by 2010 and approximately 6.4 percent of the market in 2020 . As the international community is only expected to grow by approximately $1,112,000$ sf by 2010 and approximately $1,447,000$ sf by 2020 , it is reasonable to expect that office development will readily expand, if necessary, to meet this demand based on market forces alone.

There is more than 1.5 million square feet of commercial office space under construction in the immediate vicinity of the UN Headquarters campus and seven major potential development sites that could accommodate commercial office development as-of-right under existing zoning regulations near the UN headquarters. In total, approximately 1.11 million square feet of commercial office space could be developed as-of-right near the UN Headquarters which could potentially accommodate UN-related uses, permanent missions, and/or consular uses. The four former Con Edison sites, which are one of the largest tracts of undeveloped land (soft-sites) within Manhattan, represent some of most viable sites for UN-related uses, permanent missions, and/or consular uses in the future. Located between three to seven blocks from the UN Headquarters, these four properties are in close proximity to the UN Headquarters campus and could potentially accommodate approximately 1.0 million square feet of commercial office/meeting/conference space in a concentrated area, as-of-right under current zoning regulations.

Based on historic trends, it is reasonable to assume that office stock in CB6 will expand if necessary to accommodate the international community's future office space demands. Throughout the last twenty years, CB6's office inventory has grown by approximately 13 percent to approximately 67 million square feet. Office space vacancy rates within CB6 and Midtown have fluctuated since 1980, and have remained between 3 to 16 percent. Currently, there is approximately 5.5 million square feet (about 8 percent) of office space available in CB6. 


\section{BACKGROUND}

The name 'United Nations' was devised by United States President Franklin 1). Roosevelt, and was lirst uscel in the 'Declaration by United Nations' of January 1, 1942, during Workl War II, when representatives of 26 nations pledged their governments to continue lighting together against the Axis Powers. The United Nations (UN) oflicially came into existence in Oetober 1945, when the United Nations Charter was ratified by China, France, the Soviet Union, the United Kingdom, and the United States, as well as a majority of other signatories. These countries committed to preserving peace through international cooperation and collective security. Today, with a current total membership of 191 countries, nearly every nation in the world belongs to the UIN.

The UX, while headquartered in New York City, maintains a significant presenee in Geneva, Vienna, and Nairobi. The UN Office at Geneva (UNO(i) is a center for conference diplomacy and a forum for disarmament and human rights. The UN Office at Vienna (UNOV) is the headquarters for UN activities in the fields of international drug-abuse control, crime prevention and criminal justice, peaceful uses of outer space, and international trade law. The UN Office at Nairobi (UNON) is headquarters for UN activities in the ficlds of environment and human settlements.

The UN family of organizations consists of (I) the UN Secretariat; (2) UN programmes and funds; and (3) UN's specialized agencies, which together comprise the "UN System." As a network of organizations, the UN System performs a range of duties that affect global relations. These duties range from the decision of the Security. Council to dispatch peacekceping operations in response to international disputes, to setting standards for dir safety and communications compatibility, and to coordinating emeronery relicf of natural disasters throughout the world. Ultimately, the UN System's mission is to create an open dialogue among nations, and provide an invaluable forum through which nations can resolve differences and implement shared objectives.

Another valuable component or partnership of the UN System is the "UIN Civil Society" or related non governmental organizations (NGO's). NGO's are separate autonomous entitics from the UN System that work in close cooperation with the UIN to secure peace and prosperity throughout the world. They are committed, voluntary organizations that have a broad range of missions, mandates, and venues, and work in such diverse ficlds as human rights, the environment, and health. They are also fully involved in the international process, and are mobilizers of public opinion, policy makers, and policy implementers. Currently, New York City serves has host to more than 200 different NGO's.

Permanent missions and consular uses are also separate entities from the UN System. Although part of the international community within New York City, permanent missions and consular use's represent and serve the interests of foreign nations within the United States. Missions are the UN member states' busine'ss offices to the UIN. They defend the conomy, sovereignty, and values of individual nations (nember states) in the UN. 
Currently, New York (ity scrves as host to 188 permanent missions (Kiribati, Palau, and East Timor) do not have permanent representation in New York City). Consular offices have no connection to the UN and seric as the official representation of a forcign state within New York City. A consulate office serves members of the general public in matters pertaining to travel to and residence within its country's boundarics, general information about its country, and promotes the development of trade between its country and the United States. A consulate office is the cultural and information liaison between the United States and a foreign nation.

\section{THE UNITED NATIONS SYSTEM- ORGANIZATIONAL STRUCTURE}

The UN System is a network of more than 30 affiliated organizations that serve to resolve the problems which challenge humanity. It is a global effort to improve the quality of life throughout the world by working w $^{\prime}$ promote peace and the respect of human rights, preserving the environment, combating discase, protecting intellectual property rights, fostering development and humanitarian assistance, and reducing porerty. The liN System provides an invaluable utility that enables nations to peacefully resolve disputes, reach collective decisions, and implement shared objectires.

\section{A. Six Main Organs of the United Nations}

The UN has six main organs. Five of them - the General Assembly, the Security Council, the Economic and Social Council, the Trusteeship Council and the Secretariat - are based at UN Headquarters in Vew York City. The sixth, the International Court of Justice, is located at The Hague, Netherlands. Figure 1 - 1 provieles an organizational chart of the UN System, and each of the six main bodies of the UN is described below.

\section{The General Assembly}

The General Assembly is the UN's main deliberative body which provides an open forum for multilateral discussion of the board range of international issues covered by the United Nations Charter. Each of the (IN's member states has one representative to the General Assembly (total: 191 representatives), who in turn has one vote. Although the decisions of the Assembly have no legally binding force for member governments, the UN General Asscmbly represents a collective woice of world opinion on major international issues. It also provides a source of ethical accountability in the global community. Most of the UN's ycar round work is derived from the discussions and decisions of the General Assembly, and is carricd out by committees and other sub bodies established by the Assembly, within international conferences called for by the Assembly, and by the UN Secretariat.

The General Assembly's regular session begins each year on the third Tuesday in September and continues usually until the third week of December. In recent years, the General Assembly has been in session throughout the year. In addition to its regular sessions, the Assembly may also decide to meet in special sessions at the request of the Security Council or the majority of Member States.

Due to the great number of issues and disputes which the General Asscmbly is requested to review, the Asscmbly allocates most issuces to its six main committecs:

- First Committec Disarmament and International Security Committec;

- Second Conmittec Economic and Financial Committec;

- Third Committee Social. Humanitarian and Cultural Committec; 


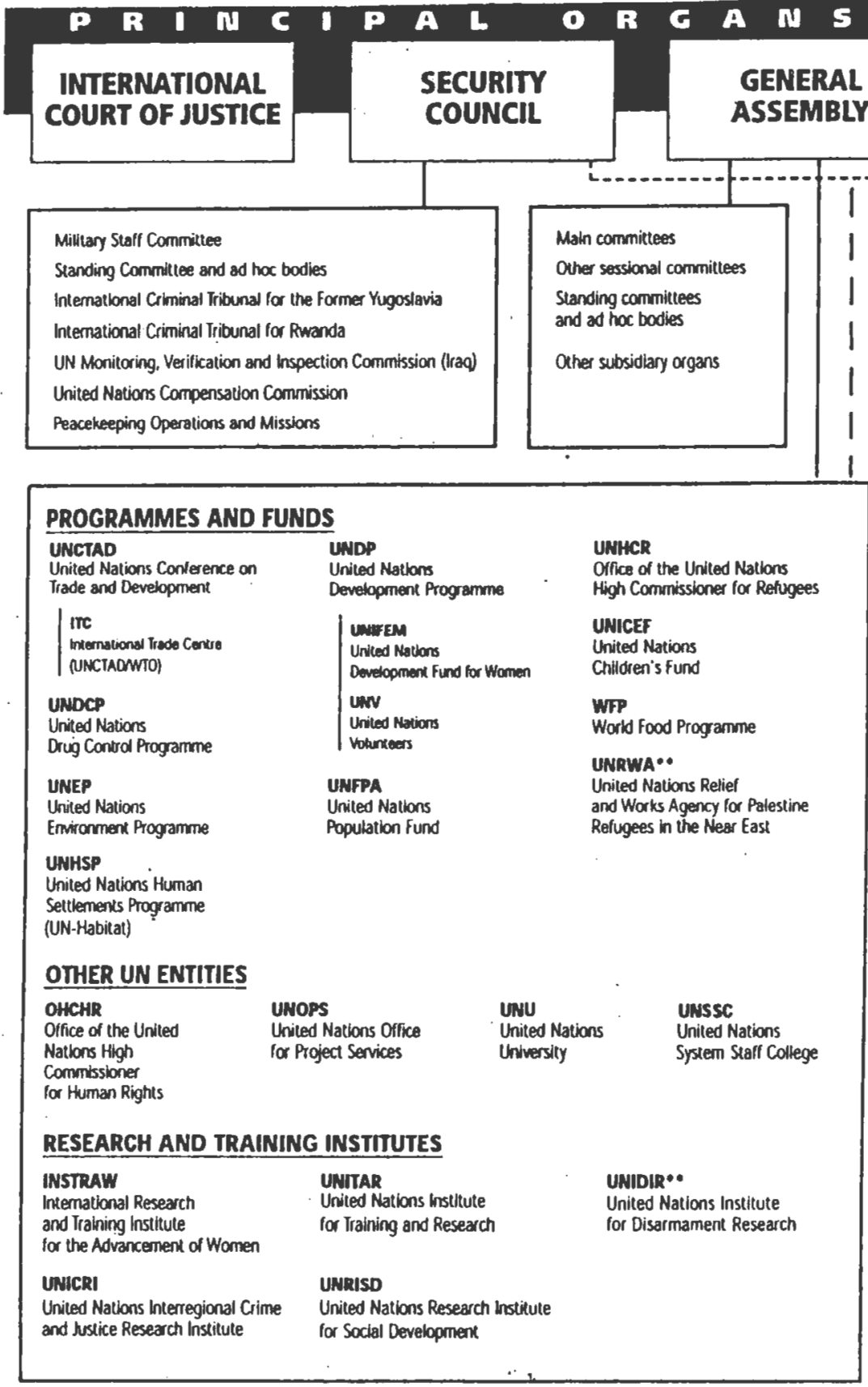

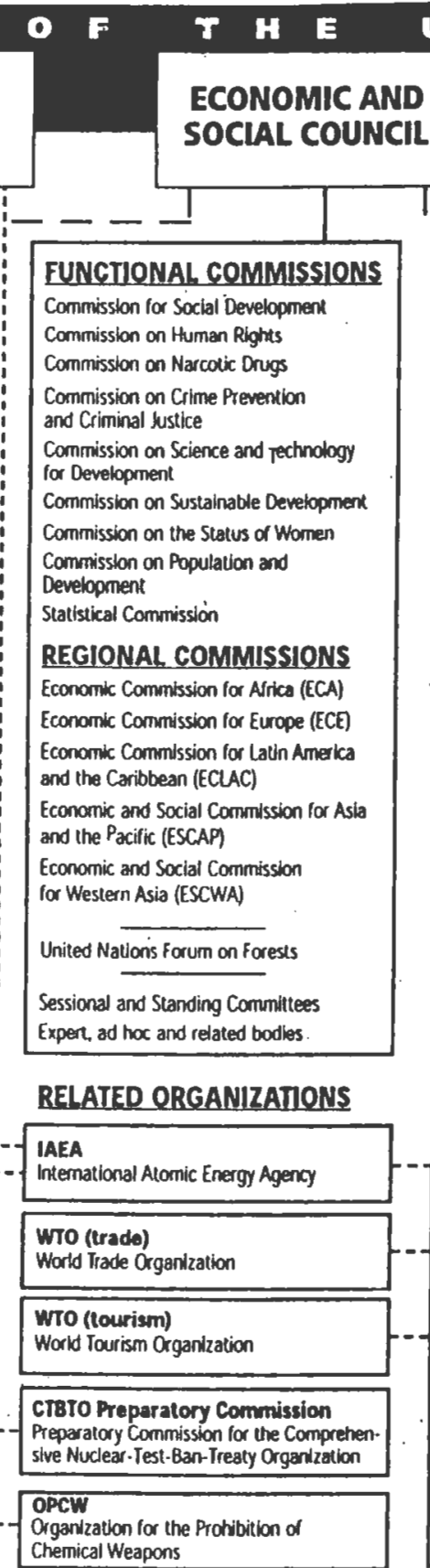

$U$ N $T=\mathbb{D}$
TRUSTEESHIP
COUNCIL

\section{SECRETARIAT}

$--\neg$

\section{SPECIALIZED AGENCIES*}

International Labour Organdzation

FAO

ford and Agriculture Organization of the United Nations

UNESCO

Unlted Nations Educatlonal, Scientific

and Cultural Organization

WHO

World Health Orgarization

WORL BANK GROUP

IBRD Internationel Bank for Recconstrudton.$$
\text { and Developmente }
$$

IDA Inecrational Devertopment Assoctation

IFC Bremations finence Coportion

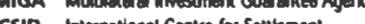

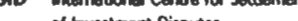

International Monetary fund

ICAO

International Civil Aviation Organization

imo

Intemational Maritime Organization

mu

Internatlonal Telecommunication Union

UPU

Universal Postal Union

wamo

World Meteorological Organization

WIPO

World intellectual Property Organization

IFAD

intemational Fund for Agricultural Development

UNIDO

United Nations Industrial Development

Organization

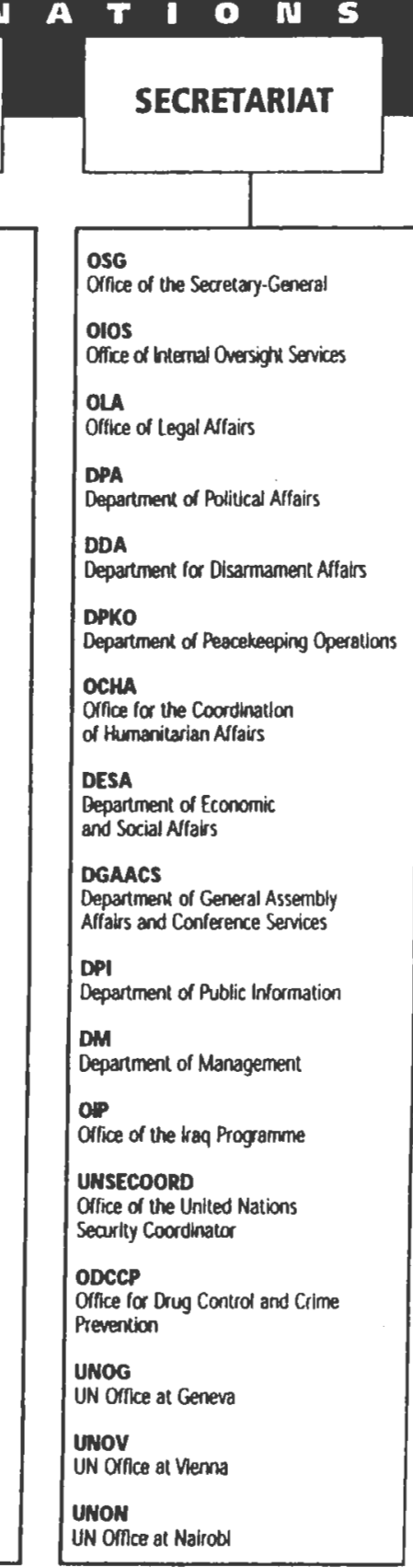

*Autonomous organizations working with the United Nations and each other through the coordinat* * ing machinery of the Economic and Soctal Councll. 
- Fourth Committec Special Political and Decolonization Committec;

- Filth Committec- Administrative and Budgetary Committec;

- Sixth Committec-..Legal Committce.

\section{The Security Council}

The UN Security Council's primary function, under the UN Charter, is to maintain and protect international peace and sccurity. It operates continuoustr and requires that a representative of each of its current members be present at all times at UN Headquarters in New York Citr. The Council, however, may decide to meet in other parts of the world at various times.

The Security Council deals with crises as they arise. It assists disputing parties in working towards peaceful and equitable settlements. Under the UN Charter, the Security Council's decisions are legally binding. Although other organs of the UN make collective recommendations to gor crnments, the Council has the authority to make decisions that UN member states are obligated to implement.

The Council is made up of fifteen members, ten nonpermanent members, periodically elected by all uN member states for a two-ycar term, and five permanent members. Although cach Council member has one vote, the system of voting gires added weight to the five permanent members of China, France, the Russian Federation, the United Kingdom and the United States. These five countries have 'veto power' and can block a proposal by casting a negative vote, even if the other four permanent and all nonpermanent members vote in favor. When a country's interests are affected, a State which is not a member of the Security Council may participate, without a vote, in the Security Council's discussions.

\section{The Economic and Social Council}

The Economic and Social Council (ECOSOC) is the central UN forum for international economic and social issues. ECOSOC was established by the UN Charter as the principal organ, under the authority of the General Assembly, to promote: (a) higher standards of living, full employment, and conditions of economic and social progress, as well as development; (b) solutions of international cconomic, social, health and related problems, and international cultural and educational cooperation; and (c) universal respect for and observance of, human rights and fundamental freedoms for all without distinction as to race, sex, language, or religion.

The ECOSOC's mandate accounts for more than 70 percent of the human and financial resources of the entire UN System. It coordinates the work of all the UN's specialized agencies and the UN programmes and funds. Through its discussion of international conomic and social issues and its poliey recommendations on them, the ECOSOC plays a key role in fostering international cooperation for development and in setting the prioritics for action.

The Council has 54 members, clected by the General Assembly for three-year terms. It mects monthly for short sessions of two or three dars and holds a major four-wcek-long session in July of cach vear, alternating between New York and Geneva. Furthermore, its many subsidiary bodies, whose members are clected by ECOSOC, meet regularly year round and report back to the Council.

\section{The Trusteeship Council}

The Trustecship Council of the UN was established to administer and supervise the Trust Territories of the LIN System. The major goals of this Council are to promote the advancement of the inhabitants of Trust Territories toward self-government or independenec. Under the UN Charter, the Trusteeship Council is authorized to cxamine and discuss reports from the Administering Authority on the political, economic, social, and cducational advancement of the peoples of 'Trust Territorics and, in consultation with the Administering 
Authority, to examine petitions from and undertake periodic and other special missions to Trust Territorics. The Trustecship Council is made up of the five permanent members of the Security Council - China, France, the Russian Federation, the Ulnited Kingdom, and the United States.

The goals of the Trusteeship System have been fulfilled to such an extent that all UN Trust Territories have attained self-government or independener, either as separate States or by joining neighboring independent countries. The Trustecship Council suspended operation in November 1994, with the independence of Palau, the last remaining UN Trust Territory. By a resolution adopted in May 1994, the Council agreed to mect as occasion required.

\section{The Secretariat}

The UN Secretariat, an international staff working at the UN Headquarters in New York and all over the world, carries out the diverse day-to-day work of the UN System. It serves and administers the programs and policies laid down by the other principal bodies of the UN. At its head is the Secretary-General, whos is appointed by the General Assembly on the recommendation of the Security Council for a five year, renewable term.

The dutics carricel out by the Sceretariat are as varied as the problems dealt with by the entire UN System. These range from administering peacekecping operations to mediating international disputes, and from surveying cconomic and social trends and problemss to preparing studies on human rights and sustainable development. The Secretariat staff also sensitizes and informs the world's communications media about the work of the UN Sistem, organize international conferences on issues of worldwide concern, monitor the extent to which the decisions of UN bodics are being implemented, and interpret specehes and translate documents into the Organization's oflicial languages.

As international civil servants, the UN Secretariat staff and the Secretary-General answer to the UN alone for their activitics. They are required to take an oath and not to seck or receive instructions fron ane Goscrnment or outside authority. Under the UN Charter, each member state undertakes an oath to respect the exclusively. international character of the responsibilities of the Secretary General and the Secretariat staff, and to refrain from secking to influence them improperly in the discharge of their dutics.

The UN employs people from all over the world, and recruits globally. Competitive examinations are used to recruit the core professional staff at the junior and middle levels. The UIN Secretariat currently emploss approximately 8,900 staff members under the regular budget, and 5,700 under specially funded programs or projects. Coming from 160 countries, the UN Sccretariat staff administers the UN Sistem's policies and programs, in Ncw York and at ficld stations around the world. The UN System as a whole- the UN Secretariat, its related programmes and funds, and the specialized agencies including, the World Bank and the IMF-- employs approximately 64,700 pcople worldwide.

\section{The International Court of Justice}

The International Court of Justice is the principal judicial body of the UN. Its headquarters seat is at the Peace Palace in The Hague, Netherlands. The International Court began work in 1946, when it replaced the Permanent Court of International Justice which had functioned in the Peace Palace since 1922. It operates under a Statute similar to its predecessor, the Permanent Court of International Justice, and is an integral part of the UIN Charter.

The Court has a dual role: (1) to settle in accordance with international law the legal disputes submitted to it by Member States; and (2) to give advisory opinions on legal questions referred to it by duly authorized international organs and agencies. 
The Court is composed of 15 judges, cach clected to nine-vear terms of office by the UN General Asscmbly and Security Council. It may not have more than one judge of any given nationality. Elections are held every three years for one-third of the seats, and retiring judges may be reelected. The members of the Court do not represent their governments but are independent magistrates.

\section{B. The UN Programmes and Funds}

The following provides a small subset list of the numerous UN programmes and funds which report directly to the UN General Assembly or the UN Economic and Social Council. The UN International Children's Emergency Fund (UNICEF), the UN I) evelopment Program (UNI)P), the UN Population Fund (UNFPA), and the Office of the UN High Commissioner for Refugecs (UNHCR) represent a small sample of the many diverse UN programmes and funds that work for declopment, humanitarian assistance, and human rights across the globe. The following provides a brief overview of the above-listed programmes and funds:

UNICEF: The United Nations International Children's Emergency Fund Founded in 1946, this organization advocates and works for the protection of children's rights, to help the young mect their basic needs and to expand their opportunitics to reach their full potential. UNICEF is mandated by the UN General Assembly and guided by the Comention on the Rights of the Child. Currently, UNICEF is headquartered in New York City.

UNDP: The United Nations Development Program-Founded in 1965, with the merger of two carlier programs, this organization is the UN's largest source of assistance for sevelopment and the main body for coordinating such development. UNI)P acts as a urifying force for sustainable human development and international cooperation. At the request of governments, the UNIPP assists countries in building capacity for good governance, popular participation, and private and public scctor development and grow th with cquity. UNDPP delivers most of its services via seren sub-regional facilitics and 132 country offices throughout the world. The UN Derelopment Program Regional Burcau for all sub-regions is currently headquartered in New York City.

UNFPA: The United Nations Population Fund-Created in 1969, this organization is the largest international source of population assistance. UNFPA is designed to assist dercloping countries in providing quality reproductive health and family planning services on the basis of individual choice, as well as formulating population policies that promote sustainable development. Through developing education programs, quality health services, and employment opportunities, UNFPA attempts to empower women and men with choices and awareness of population and development issues. Currently, UNFPA is headquartered in New York City.

UNHCR: The United Nations High Commissioner for Refugees. First creatcel in 1951 by the Gencral Assembly, this organization scries as a non-political, humanitarian tcmporary reliel agency and provides protection and assistance to the world's relugecs. UNHCR is currently headquartered in Genera, Swit\%crland. 


\section{The UN Specialized Agencies}

The UN specialized agencies, which are located in various cities throughout the world, are related to the UN through special cooperative international agreements. They are separate, autonomous organizations that coordinate their work with the UN. They work in such diverse areas as health, agriculture, international aviation, finance, and metcorology (sec the list below). The following provides a list of many of the UN's current specialized agencies.

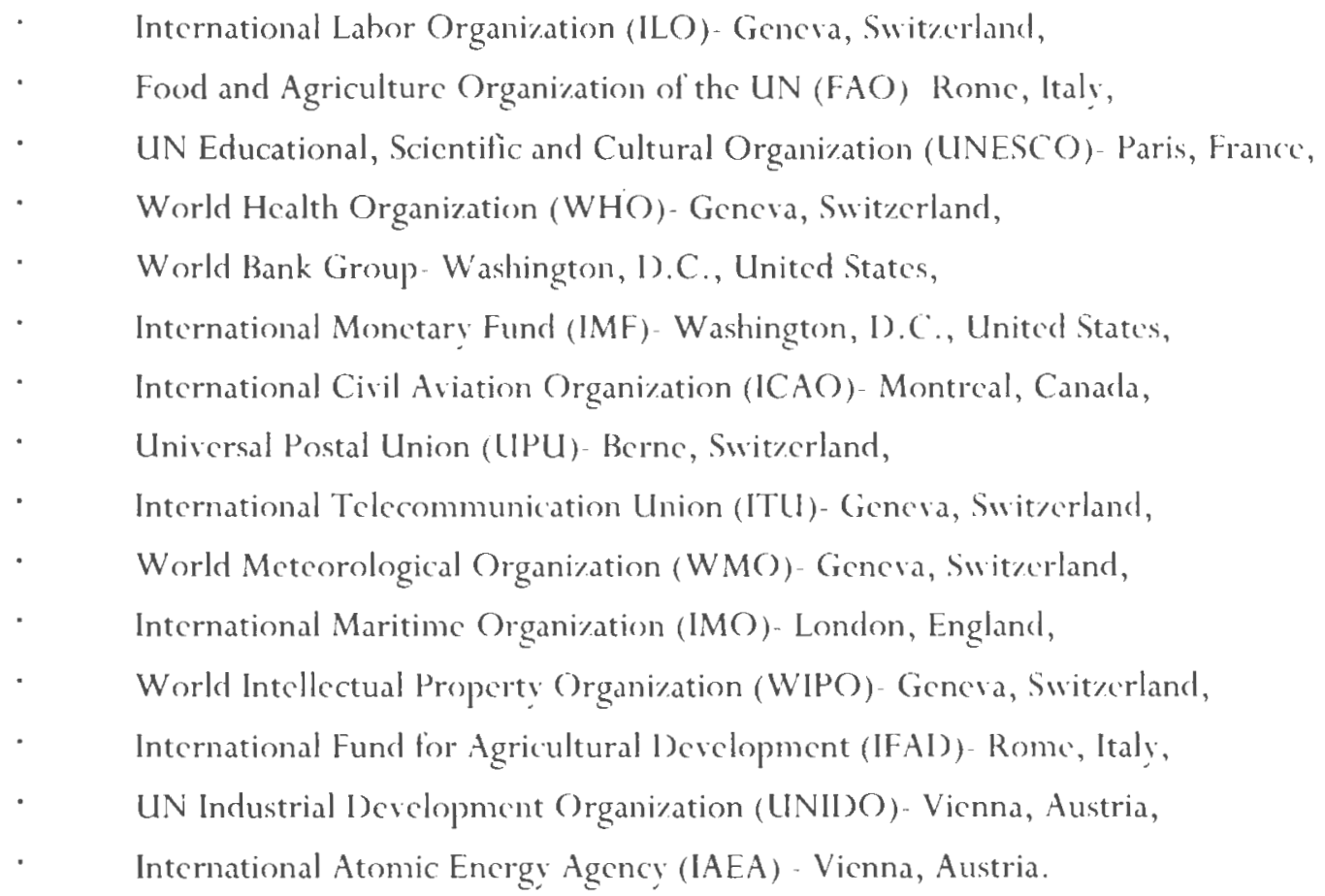

\section{HISTORY OF THE UN HEADQUARTERS IN NEW YORK CITY}

The UN Headquarters campus, occupving 18-acres, is located along the castern edge of Midtown, on the banks of the East River, directly north of the New York Citv Robert Moses Plavground and Park. It is bounded by East $48^{\text {th }}$ Strect to the north, the East River to the cast, East $42^{\text {nd }}$ Street to the south, and UN Plaza (First Avenue) to the west (see Figure 12 ). As the property is owned by the UN, it is an international property. No city, state, or federal officers or any other representative official of the US may cnter UN Headquarters without the permission of the Secretary - General of the (IN. However, the UN is bound by an agreenent with the (IS to) prevent the UN Headquarters campus from becoming a refuge lor persons asoiding arrest.

\section{A. Site Selection and Key Design Features}

Nations from across the globe competed to be selected as the headquarters seat of the UIN. The decision on where to locate the UIN Headquarters district was finally made in February 1946 during the lirst mecting of the General Assembly. A special site committee of the UIN cxamined a number of possible sites throughout the world. US Cities such as Philadelphia, San Francisco, and Boston were all considered. Manhattan had been 


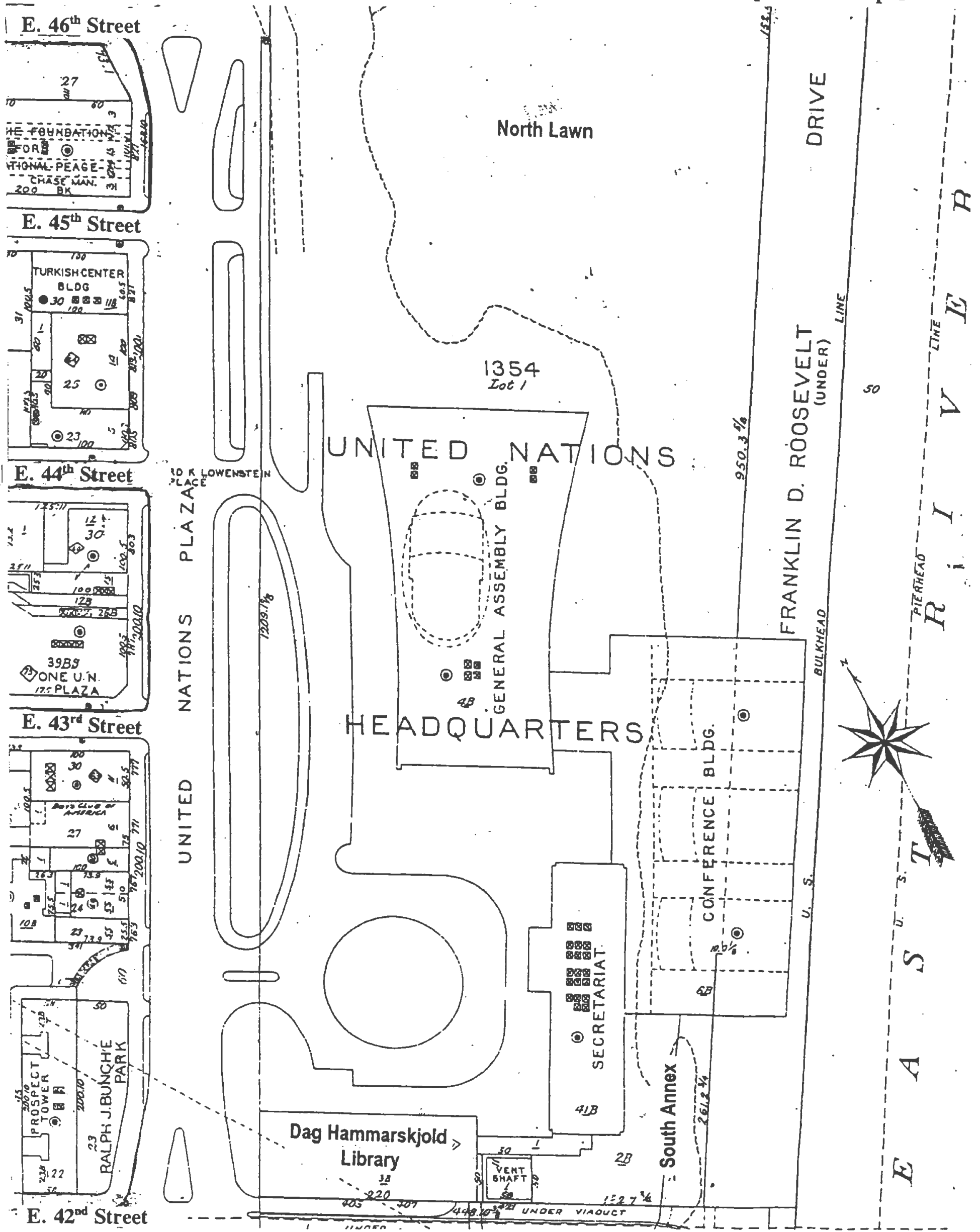


considered too crowded to be a serious candidate. However, a last-minute offer by John D). Rockefeller, Jr. to donate a large parcel of land along the East River waterfront, made New York City a scrious contender for the UN Headquarters site. In addition, the City of New York also complemented the Rockeleller site with the donation of several City-owned properties adjacent to the site, as gifts to the UN. The area at this time was blighted with slaughterhouses, light industry, and a railroad barge landing.

Once the headquarters site was selected, an 11 -member board of design was chosen to plan the world headquarters campus. This board was composed of diverse and internationally renowned architcets nominated by their respective governments.

As the site was a relatively small property, the design board envisioned the UN Headquarters district as a park like campus that would stretch from First Avenue to the East River's edge with one tall building accommodating the UN's tremendous office space demand. The UN Sccretariat building was lecated at the south end of the sitc to allow access along East $42^{\text {mt }}$ Strect, and a Conference Building was located on a pier extending over the FDR Drive. Large statues and manicured law ns adorned a large section of the northern part of the grounds space. Although the UN's international status did not bind the UN to New York City building regulations, both of these structures were built in compliance with New York City regulations at the time. Building construction at the UN Headquarters was completed in 1951.

\section{B. The Present Buildings of the UN Headquarters}

The present buildings of the UIN Headquarters campus generally accommodate two distinct types of work: (1) the delegate work of the UN General Assembly, UN Security Council, and the UN Economic and Social Council, and (2) the administrative and analytical work of the UN Secretariat. Representatives of 191 countries come to the UN Headquarters in New York City to discuss and decide global issues of peace, justice, and cconomic well-being, while the UN's administrative staff work towards implementing and craluating these policy decisions. Currently, there are six buildings that stand "ithin the UN's New Y'ork City headquarters scat: the Secretariat building; the General Assembly building; the Conference building; the Library building; the North Lawn building, and the South Annex (sce Figures $1-3$ through 1 6). In addition, the UN also owns a small building dircetly west of the UN Headquarters campus on the northwest corner of First Avenue and East $45^{\text {th }}$ Street (sec Figure 1-3). Each of these structures is described below.

Secretariat Building- The Secretariat building is approxinnately 550 -lect tall, with an extcrior made of aluminum, glass, and marble. The building is 39-storics tall, with three bascment levels, as well as a connection to the Conference Building. Overall, there is approximately 653,000 square fect of uscable office space within the Secretariat building.

General Assembly Building- The Gencral Asscmbly buikling is a plenary hall that is a sloping structure with concave sides (see Figure 1-3). It is approximately 380-feet long and 160-feet wide and topped with a shallow dome. Its north end opens onto a landscaped plaza and scrues as the main public entrance to the headquarters scat. Primarily, the building is composed of translucent glass, marble, and limestone. Four medium sized mecting rooms and a large conference room are located on the concourse level, and retail shops and services can be found at the basement level. The General Assembly Hall, the largest room in the UIN, with seating capacity of 1,800 , is located on the second floor (sec Figure 1-7). 


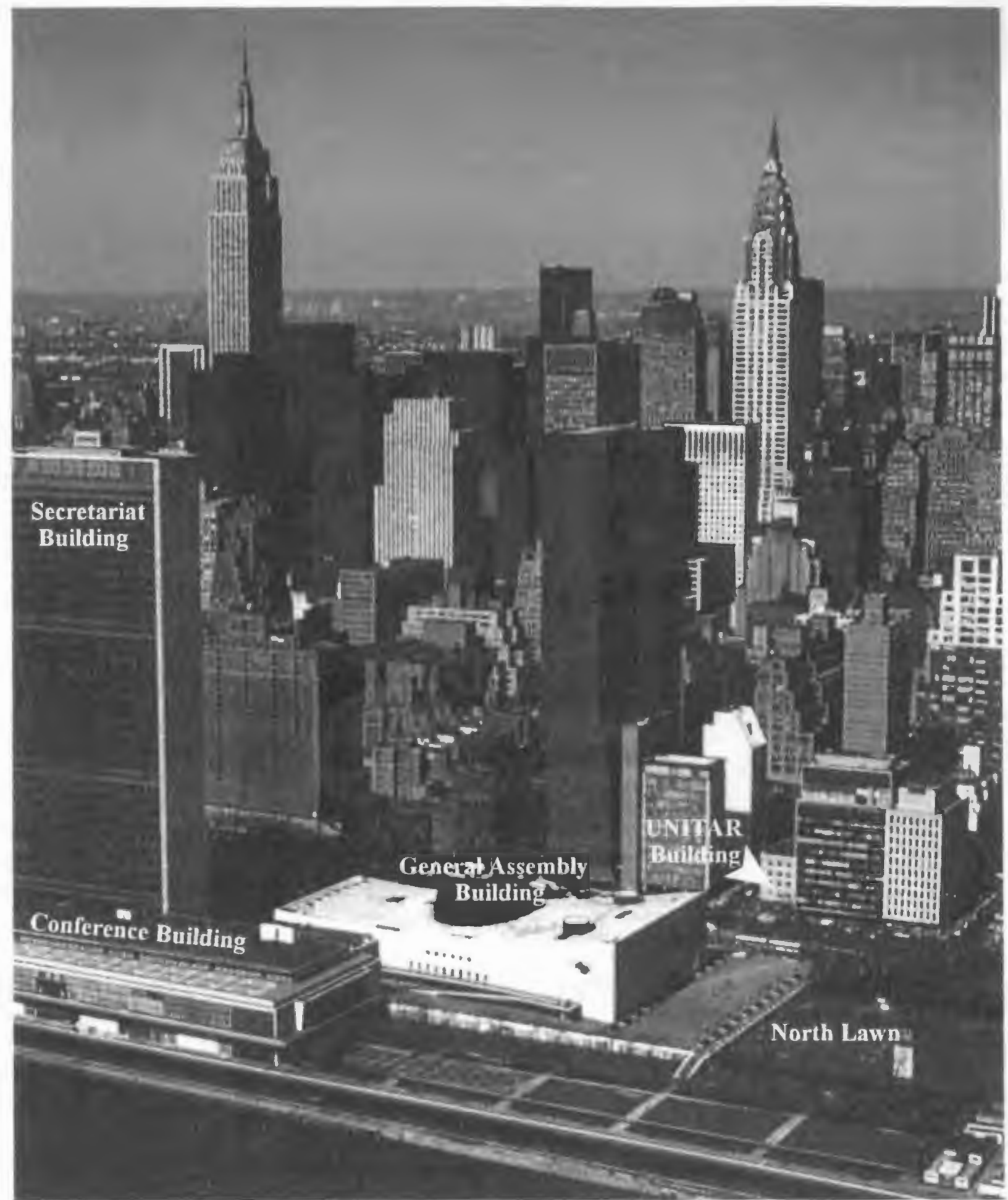

View looking southwest to the UN Headquarters from the East River. 
Assessment of the Future Office Space Needs of the International Community Figure 1-4 UN Secretariat Building

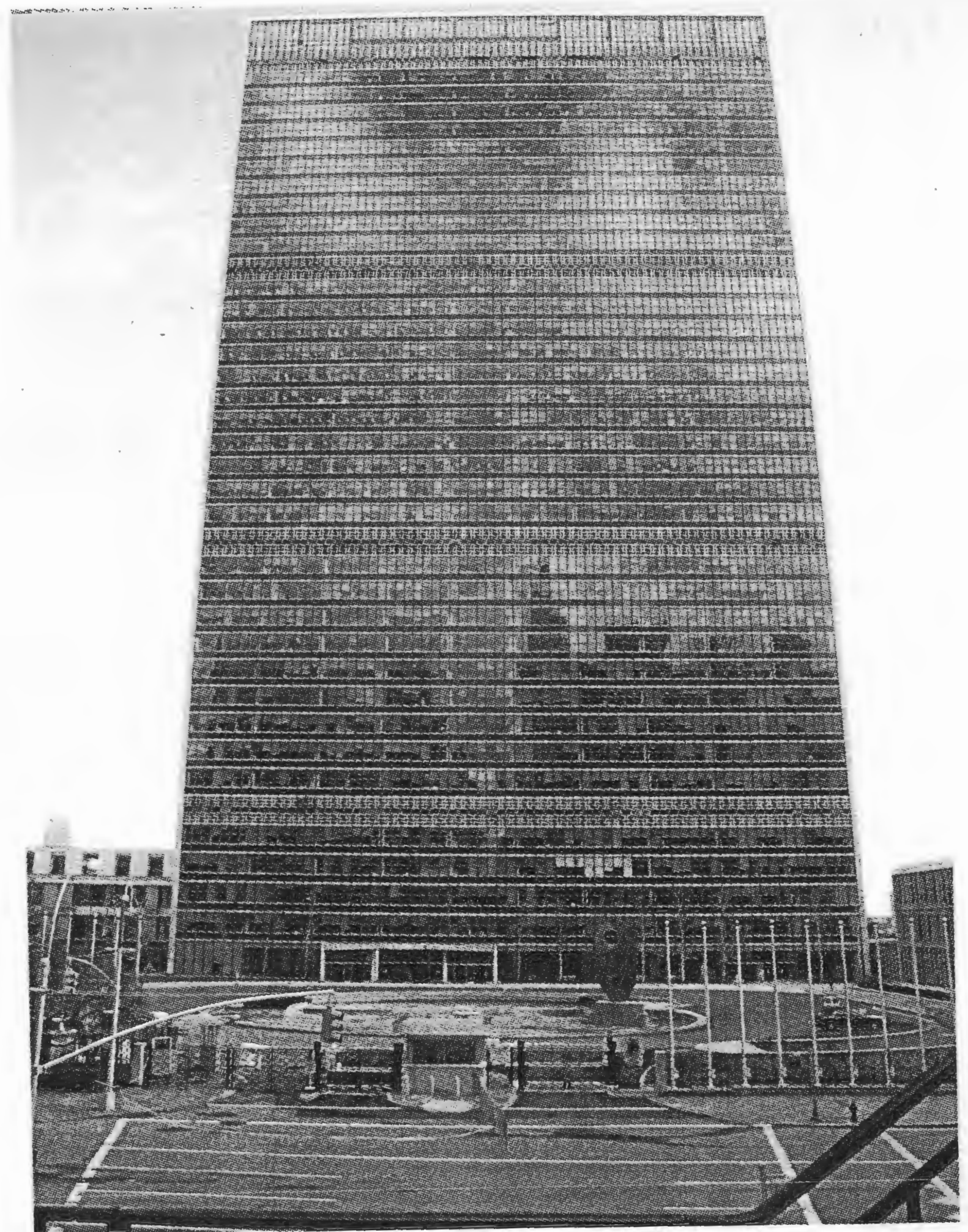

View looking east to the UN Secretariat building from Tudor City. 


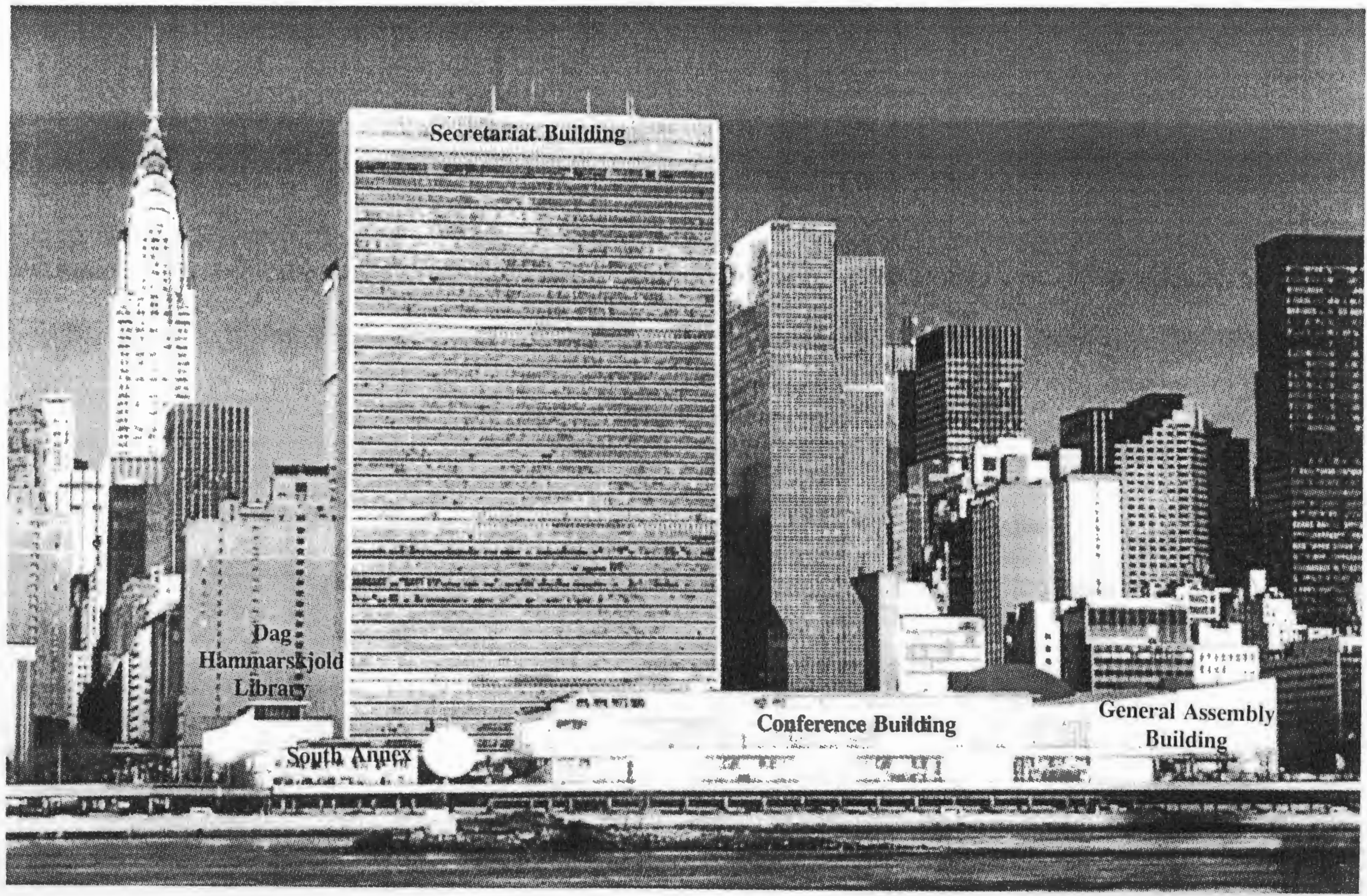




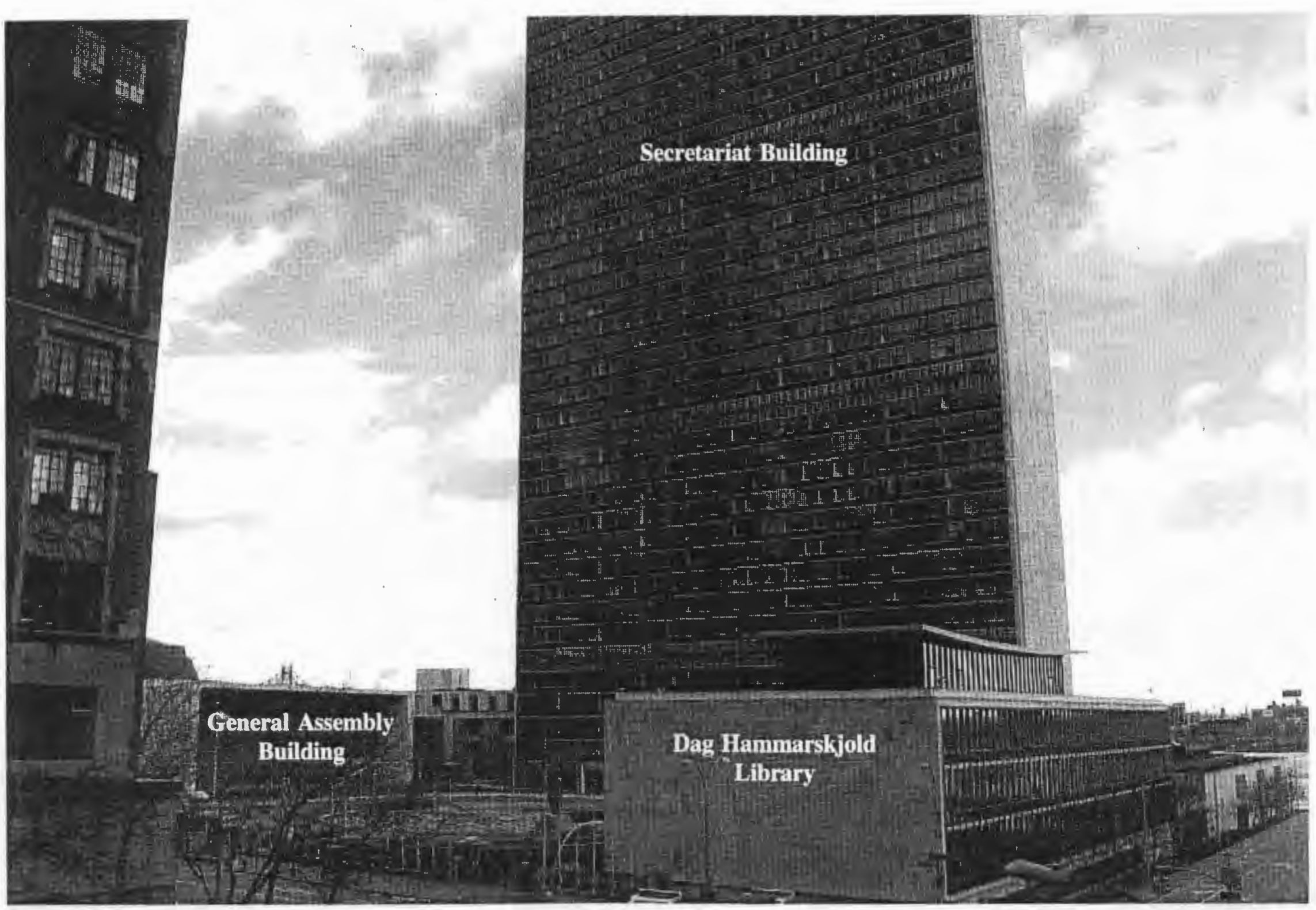

View looking northeast to the UN Headquarters from Tudor City. 


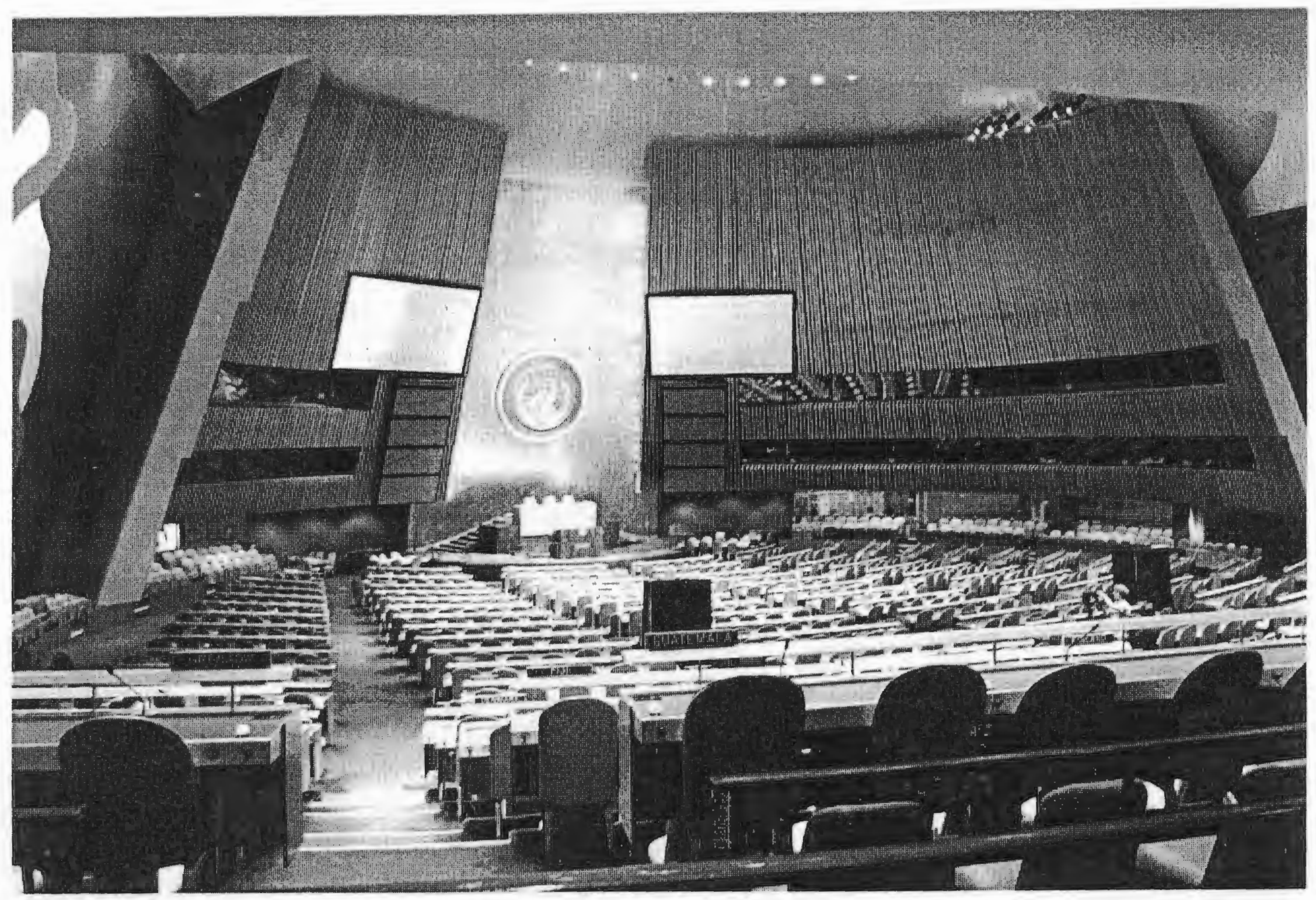


- The Conference Building. The Conference Building, which connects the General Assembly and Secretariat Buildings, extends approximately 400 feet along the waterfront and is cantilevered over the Franklin 1). Roosevelt 1)rive. It is four stories tall and contains the complex's dining rooms and cafeterias, the Security Council Chamber, the Trustecship Council Chamber, and the Economic and Social Council Chamber (sec Figure 1-8\& 1-9).

The Dag Hammarskjold Library- The Dag Hammarskjold Library, built in 1961 as a gift to the UN from the Ford Foundation, is located at the southwest corner of the UIN grounds and is linked to the Secretariat Building. It measures about 219 feet wide by 84 feet long and consists of six levels-- threc-above-grade and three below grade. This building is primarily constructed in white marble, glass, and aluminum.

The North Lawn Building- The North Lawn building is located within the northern portion of the UN Headquarters campus, beneath the great lawn. It has two basement levels, and scrves as the UN's printing plant.

The South Annex Building- The South Annex building is connected to the south side of the Secretariat building, and is directly behind the Dag Hammarskjold Library, along the East River waterfront. It is a 2 story building that predominantly serves as a cafeteria.

The UNITAR Building The UNITAR building is not actually located on the UN Headquarters campus. It is, however, owned by the UN and is located directly across the strect of the UN Sccretariat building on the northwest corner of East $45^{\text {th }}$ 'Strect and First Avenue. The building is 5 -stories tall and is composed primarily of stone.

\section{UN System's Space Utilization}

Since the inception of the UN, the membership of the organization has vastly expanded and the UN'S efforts and scrvices have intensified (sec Table 1-1). As the UN complex was originally designed to accommodate approximately 70 member states, several physical alterations and expansions to the headquarters campus have been necessitated by the drastic increase in membership. Over the last 50 years, the interiors of the existing buildings have been altered to accommedate the many additional member states that have joined the Organization, since its inception. In 1964, a $\$ 3$ million dollar expansion program that alfected mainly the mecting areas was completed to accommorlate some of the UN's space needs. In 1976, the seating area of the General Asscmbly Hall and all the other major conference arcas were refurbished to accommodate approximatcly 146 member states.

As the UN organization has began to outgrow the existing Secretariat Building, it has also been necessary for the UN Scerctariat (UN's administrative body), as well as the UN System as a whole to rent office space in adjacent buildings outside of the UN Healquarters campus. However, private enterprise has largely becn ineffective in providing the UN System with affordable, high-quality office, conference, and mecting facilities, as well as adequate hotel accommodations, housing, and parking facilities for UN staffers, foreign diplomats, and other related parties, in close proximity to the UIN Headquarters. The major land uses surrounding the UN Headquarters throughout the $1960^{\circ}$ s, 1970 's, and much of the 1980's were largely incompatible with the UN related uses, and the existing office stock was extremely limited and typically older and of low er quality than much of Midtown and Downtown Manhattan. 


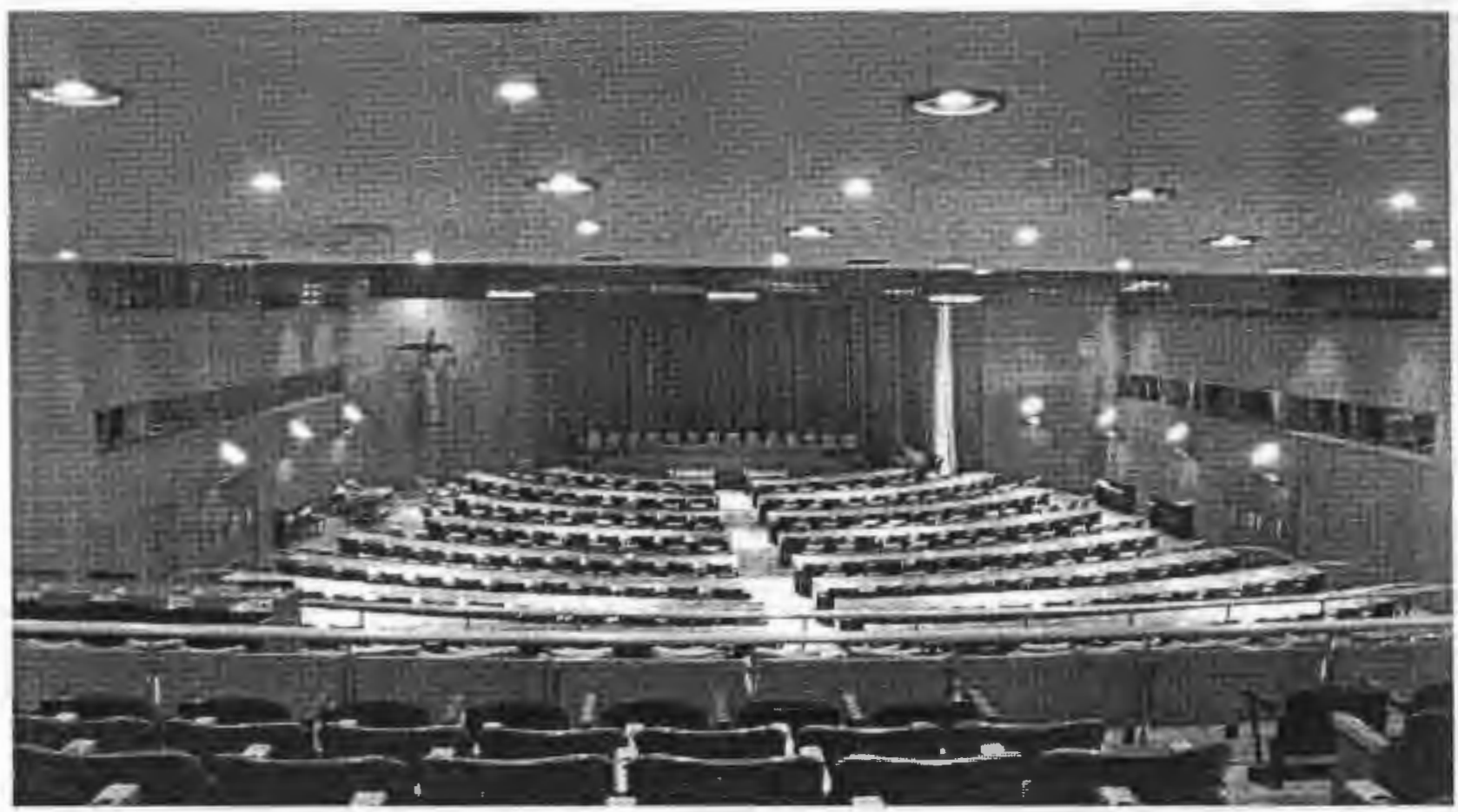

Figure 1-8: View of Trusteeship Council Chambers

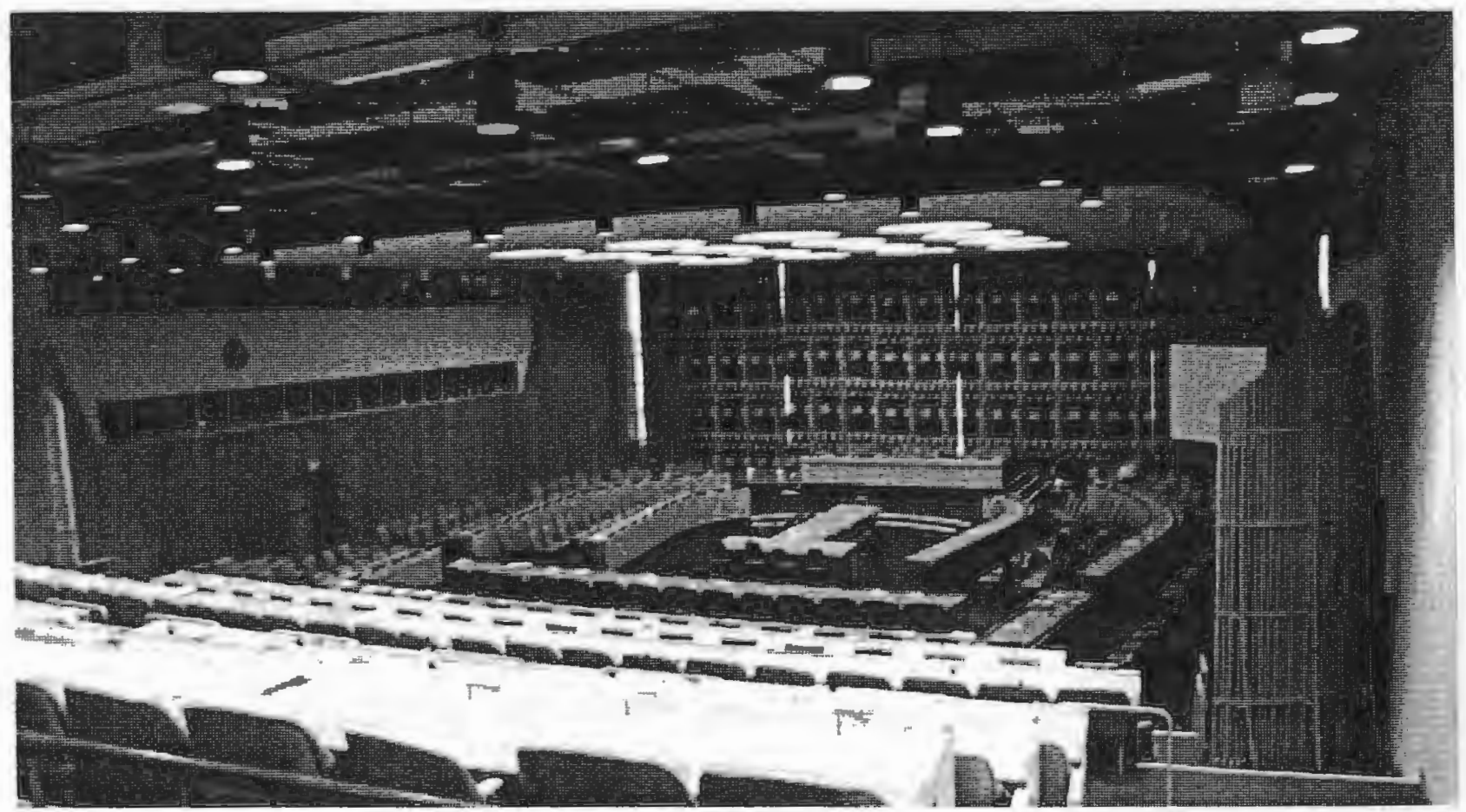

Figure 1-9: View of Economic \& Social Council Chambers 
Table 1-1: Membership of the UN

\begin{tabular}{lcccccccc}
\hline & $\underline{194 j}$ & $\underline{19 j 5}$ & $\underline{196 j}$ & $\underline{197 j}$ & $\underline{1990}$ & $\underline{199} \underline{2000}$ & $\underline{\underline{20(0)}}$ \\
No. of Member States & 51 & 76 & 117 & 144 & 159 & 179 & 189 & 191 \\
\hline
\end{tabular}

Source: United Nations Website, www.un.org/Oversiew/growth.htm

In response to private enterprise's inability to provide the UN System with sufficient, suitable, and affordable facilities, the Ncw York State Legislature and the City of New York cstablished a public benefit corporation (United Nations Derclopment Corporation), in 1968, to respond to the increasing needs and accommodations of the UN, its affiliated uses, and its member states. The United Nations Development Corporation (UNDC) was mandated to formulate development plans for the coordinated derelopment of the United Nations Development District (sec Figure 1-10) and to provide advice and services with respect to real estate needs and development to the UN and its related uses in New York State. UNDC was given the authority and responsibility to survey the present and future needs of the UN System and its permanent missions in order to formulate a development plan for the United Nations Development District. It was also provided with the power to acquire real property and/or construct, rchabilitate, or improve existing buildings to be used by the UN System and/or related uscs. In addition, UNDC has the authority to linance and/or sponsor projects and manage propertics for UN-related uses.

Since its cstablishment in 1968, UNI)C has dercloped and operated approximately 1.8 million square feet of space in the vicinity of the UN Headquarters campus. UNDC's three largest construction projects inchuded One, Two, and Three UN Plaza. One and Two UN Plaza are distinct 39- and 40-story towers that are located directly west of the UN Secretariat building and contain more than 700,000 st' of office spacc. Various departments of the UN Secretariat, UNDP, and a few permanent missions are located in One and Two UN Plaza (sec Figure 1-11). Three UN Plaza is located directly across East $44^{\text {th }}$ Strect from the other two office tower buildings, and is the headquarters of UNICEF. Apartment units and a trec-lined public plaza are also contained within Three UN Plaza.

Currently, the New York City UN Headquarters campus accommodates four major groups:

- Delegations- who represent 191 UN member states and who send more than 4,000 to 5,000 persons to New York cach year for the annual session of the General Assconbly,

- The UN Secretariat- UN's administrative staff numbering about 5,700 persons in New Y'ork out of a total of about 14,600 throughout the world,

- Visitors- annual average of approximatcly 1,000,000,

Journalists- more than 1,300 are permanently accredited, while more than 5,000 are present during major mectings. 
Assessment of the Future Office Space Needs of the International Community Figure 1-10 United Nations Development District
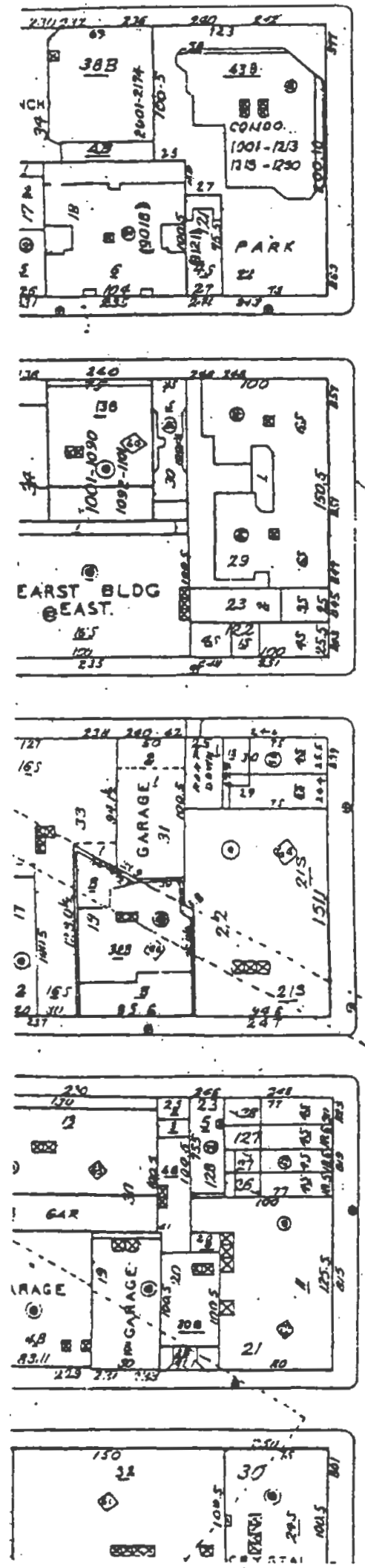
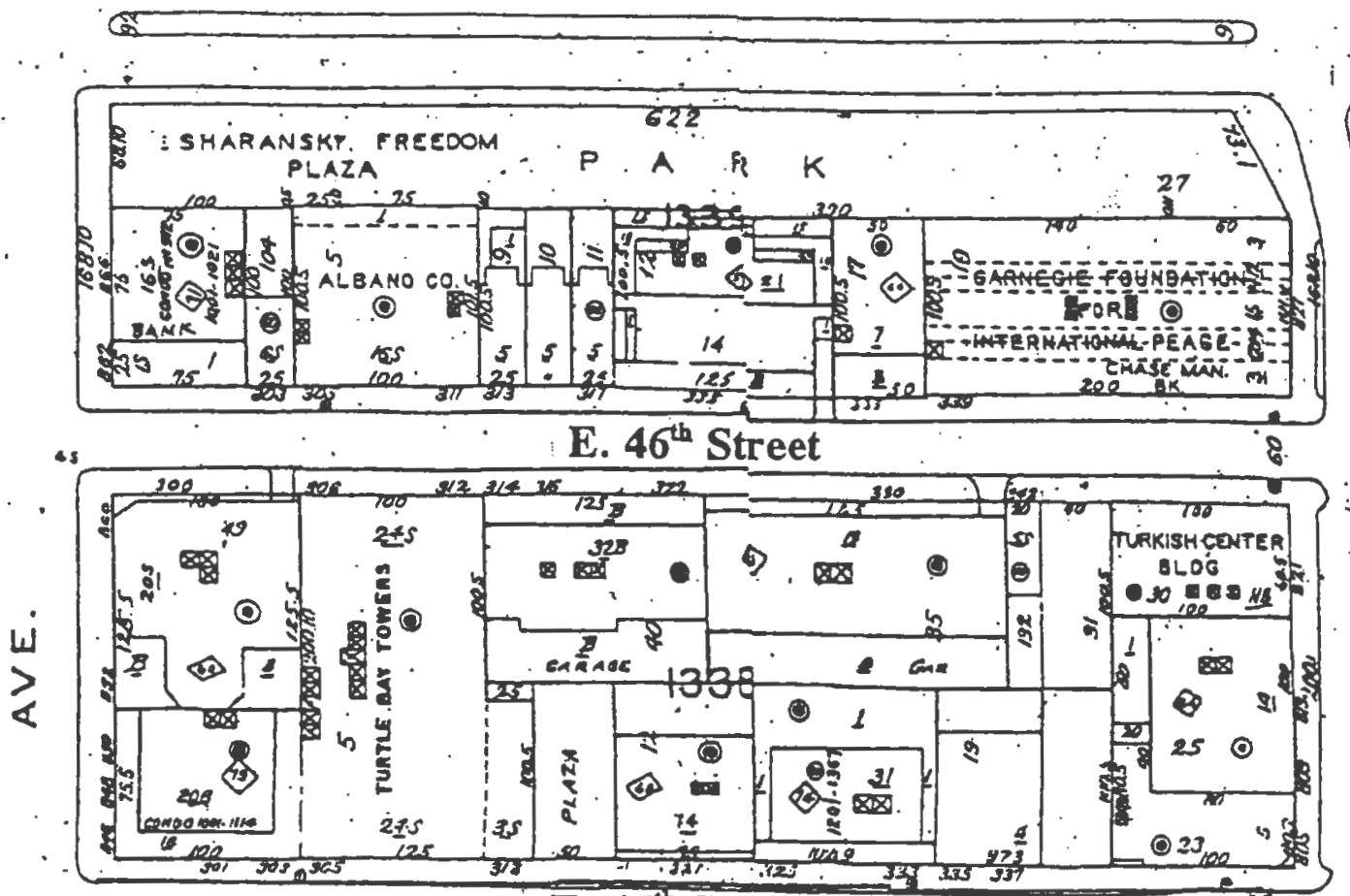

E. $45^{\text {th }}$ Street

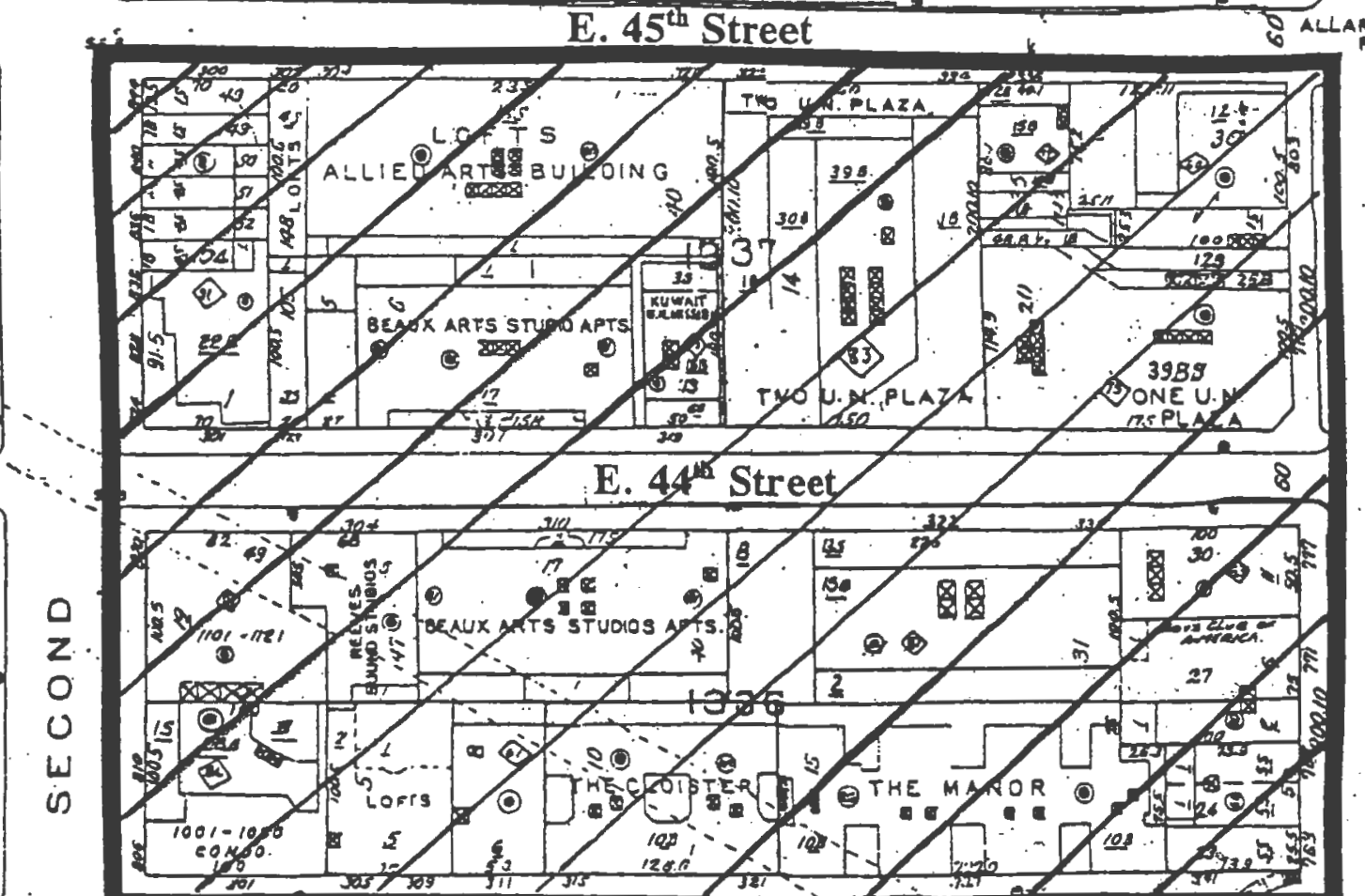

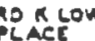

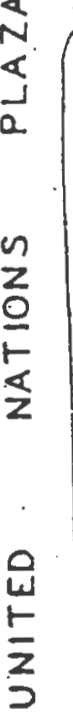

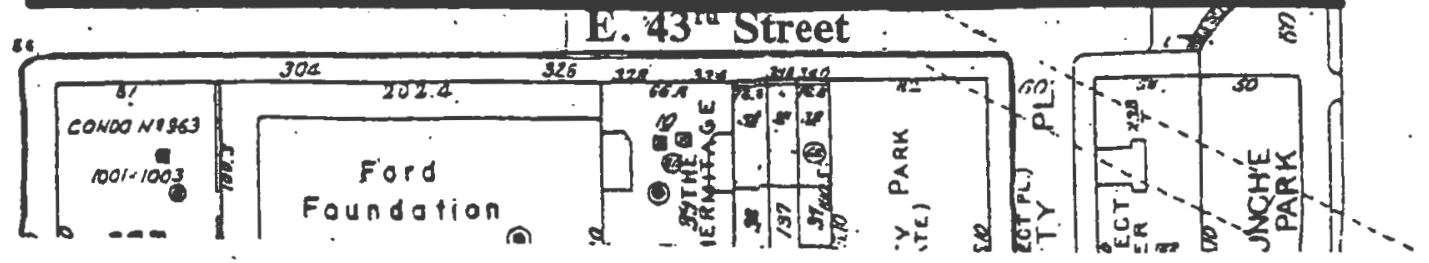




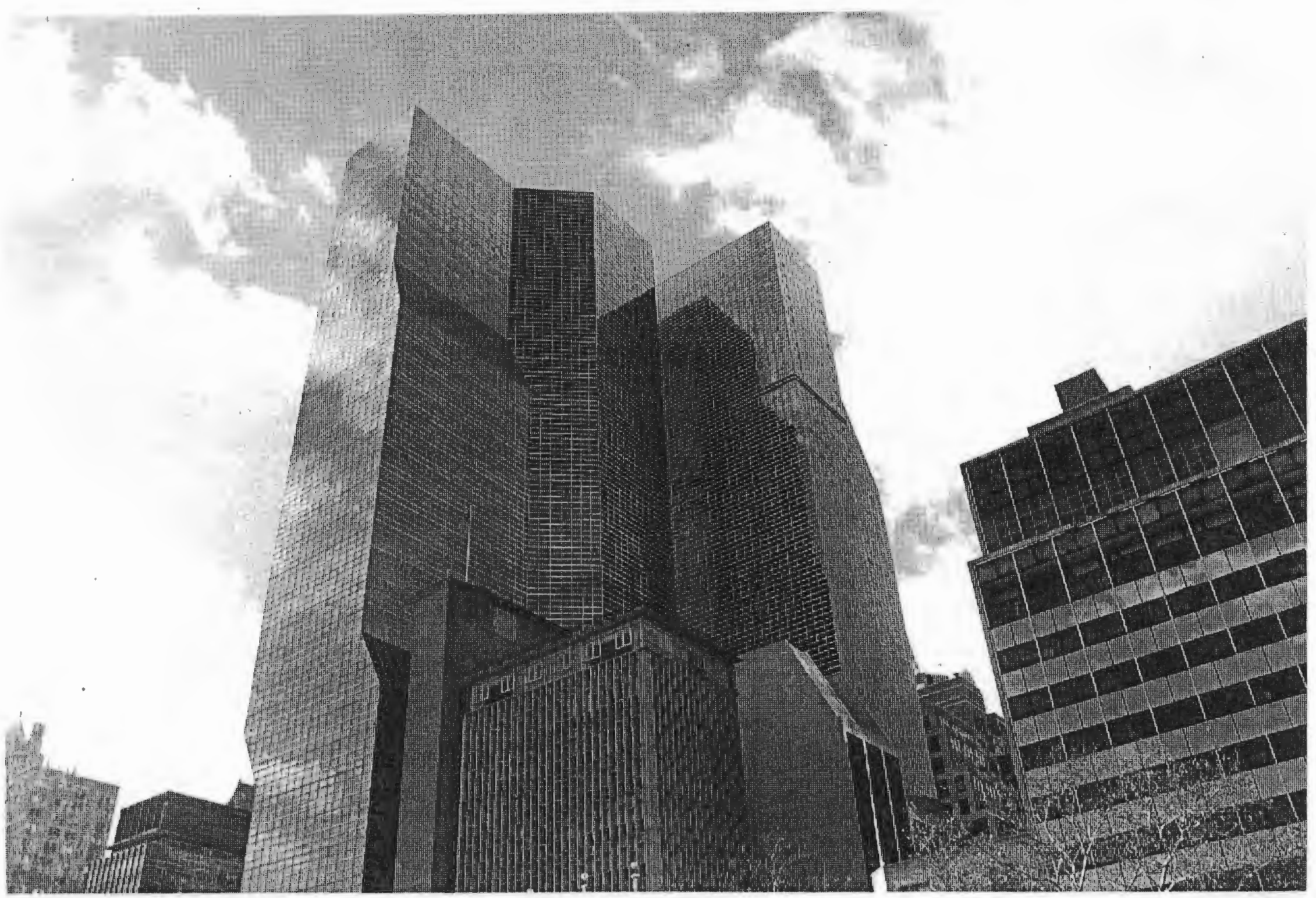

View of One and Two UN Plazal looking southwest from the North Lawn of the UN Headquarters campus. 


\section{EMPLOYMENT IN THE UNITED NATIONS}

The formation of the UN Sccretariat was intended to provide a corps of dedicated professionals from around the world who would set aside national differences in the interest of world peace. Pay was to be comparable to that of U.S. government workers, with extra benefits to entice forcign workers to live abroad. As mentioned on page 1-4, the UN employs highly qualificd people from all orer the world through rigorous competitive examinations and intensive international recruiting. Salaries for professional staff are derived from a direct, net comparison with the carnings of U.S. federal civil service employecs and are regulated by the International Civil Service Commission. The International Civil Service Commission is an independent, 15 member body composed of experts from all across the globe. On average, UN salaries are significantly lower than other international organizations such as the European Union (EU), the Organization for Economic Cooperation and Development (OECD), the North Atlantic Treaty Organization (NATO), and the World Bank.

The UN Secretariat staff members are not diplornats and must pay taxes. For example, UN Secretariat staffers, who are US citizens, pay US income taxes and French citizens, who are UN Secretariat staffers, pay income taxes to France. UN employecs are not permitted to accept any supplementary payments or subsidies from their respective Governments in order to not compromise their independence as international civil servants.

Currently, the UN Secretariat employs approximately: 8,900 staff members under the regular budget and 5,700 under specially funded programs and projects. The UN System as a whole the UN, UN programmes and funds, and the UN's specialized agencies- employs approximately 64,700 people worldwide. Table 1 - 2 shows the employment numbers for the entire UN System, the worldwide UN Scerctariat staff, and the UN Secretariat staff at the New York City hearlquarters for 1983, 1993, 1995, and 2000.

Table 1-2: The United Nations System Employment Statistics

\begin{tabular}{lcccc}
\hline & $\mathbf{1 9 8 3}(1)$ & $\underline{1993(2)}$ & $\underline{1995}$ & $\underline{2000(3)}$ \\
$\begin{array}{l}\text { Worldwide Employment } \\
\begin{array}{l}\text { UN Secretariat } \\
\text { Worldwide }\end{array}\end{array}$ & $\mathbf{4 6 , 0 0 0}$ & 53,589 & $52,100 *$ & 64,700 \\
$\begin{array}{l}\text { NYC Sccretariat } \\
\text { Headquarters } \\
\text { Employment }\end{array}$ & 11,964 & 14,625 & $13,896 *$ & 14,600 \\
\hline
\end{tabular}

Sources:

(1) Trimble, Jeff (February 21, 1983) The UN: A Burcaucrat's Land of Milk and Hener. US News and I1orhl Report

(2) Beigbeder, Yves (1997), The Internul Hanagement of United Vations Orgunirations: The Long Quest for Reform.

(3) Composition of the Secretariat Report of Secretary General (Sept. 28, 2000), "ww un.org

* Childers, Frskine \& Urquhart, Brian (1994) Renewing the Unitct Vutions Sictem. Motala Frafiska, Siweden.

** United Vations Wrbsitc, $11 \cdots \cdots$.un.(s)! 


\section{A. Current Management Trends Affecting the UN Secretariat's Employment}

The current UN employment patterns have generally cvolved as a result of the UN Sccretariat's change in management style, decentralization, and financial constraints. The effects of these combined efforts were meant to make the UN leaner and more effective. Initiatives including the consoliclating of several Secretariat bedics, streamlining management, and shifting resources from administration to development work was initiated by the Secretary General in July 1997. Each of these three factors is discussed below.

\section{Human Resource Management Changes}

In the carly 1990's, a number of private entities provided the UN with recommendations of more effective management. These private entities suggested that management reform should be geared towards improving the effectiveness of the UN and not at cutting its budget. The basis for a more effective managenent process has been clearly defined by the General Assembly. It lays out an effective system of accountability and responsibility, and requires the establishment of clear responsibilitics for program delivery, including performance indicators as a measure of quality control.

\section{Decentralization}

The decentralization of the UN was another issue that arose from the management reform and reorganization discussions of the UN. In December 1989, the UN General Assembly called for a 'more decentralized and strengthened capacity of the UN System at the country level. ' UN operational activitics were reoriented to the national level versus the international level. Many UN organizations were physically relocated closer to developing countries and closer to the people in necd of international assistance. This management strategy sought to ensure that the UN organization was aware of regional and individual countries' differences and needs. The main motivation for this decentralization was to bring the UN organizations closer to the "customer' (the recipient countries and their population) and to better aclapt their cooperation or assistance to the specific needs or claims of the developing countries.

\section{Financial Constraints}

The financial strains and money shortages are nothing new at the UN, which relies cexclusively on its member countries for funding. The problem has plagued the Organization since its founding in 1945 . However, the UN's continuing financial crisis is intensifying. The financial state of the UIN remains precarious, threatening the Organization's ability to fulfill mandates given to it by its member states.

The UN runs on assessed contributions from Member States under the terms of its 1945 Charter. The Organization has never been given authority to borrow from commercial institutions. Instead, it relies exclusively on member countries to honor their treaty obligations and pay their membership dues in full and on-time. Fach country's contribution is calculated, according to a formula approved by all Member States, on the basis of its share of the world economy and ability to pay. According to the established formula, the top seren contributors to the UN are the USA (250\%), Japan (18\%), Germany $(10 \%)$, France $\left(6^{\circ} \%\right)$, Italy (5\%), the United Kingdom ( $5 \%$ ), and Russia ( $3 \%$ ) which collectively account for more than 72 percent of the regular UN budget.

Currently, the annual UN budget is approximately $\$ 1.25$ billion, although the total expenditure of the UN was \$ 10.6 billion in 1995 . This budget supports the 64,700 persons who work within the UN system. Of this annual budget, $\$ 4.8$ billion a year are spent tow ards conomic and social derelopment, to assist countrics in 
such areas as health care, sanitation, agriculture, and food distribution. The UN peacekecping operations absorbed $\$ 907$ million of this budget.

The current UN Secretariat has a zero-grow th budget of $\$ 2.5$ billion. This is clow $\mathrm{n} \$ 100$ million from 1994-95, the result of efficiency gains and the climination of nearly 1,000 jobs. Globally, the UN Secretariat staff has been cut by 25 percent, from a high of 12,000 in 198485 , to 8,900 currently.

\section{NON-GOVERNMENTAL ORGANIZATIONS}

A non-governmental organization (NGO) is any non-profit, voluntary citizen's group with a common interest that is organized at the local, national, or international level. Currently, more than 1,600 NGO's with varving missions and mandates comprise what is commonly referred to as the "UN Civil Societr." The "UIN Civil Socicty" is a diverse group of $\mathrm{NGO}$ 's that perform a brodd range of services, and humanitarian functions that bring local citizens' issue's and concerns to the forcfront. They are the UN System's invaluable links to people across the globe. They serve as experts and alvisors to the UN Sistem and help the UN monitor and implement international agreements. They also develop, implement, analye and craluate policy, provide humanitarian services, and promote political activism at the community level. In addition, each NGO strives to disseminate general information about the UN System to its constituency and build knowledge of and support for the UN Sistem at the grassroots level. Ther help the public to better understand the aims and objectives of the UN System and discuss the broad range of issues and conflicts that the UN System wreseles with on a daily basis.

For more than 50 years, numerous NGO's have been locating headquarter or regional offices in the New York City Metropolitan Area near the UN Headyuarters campus. Today more than 200 NGO's offices are located in Munhattan. Several of these are located along the castern edge of Midtown in Community Board 6, and along the Upper East Side in Community Board 8, in close proximity to the UN Headquarters campus.

\section{DIPLOMATS- MISSIONS AND CONSULATES}

Diplomats are appointed officials that represent and work for specilic Governments, not for the UN. Almost all member states of the UN maintain permanent missions or liaison offices in New York City, which in effect are their countrics' embassies to the UN and scrve their countries' interests. Missions are headed by ambassadors, known as "permanent representatises," who make up the core of the diplomatic community in New York City. Diplomats posted at the UN enjoy the legal privileges and immunities allowed under international law for diplomats crerywhere. Each year, between September and December, nearly t,000 to 5,000 diplonats come to New York to take part in the annual session of the General Assembly. Almost all of the permanent missions in New York City are located within a few blocks of UN Headquarters within the boundaries of Manhattan Community Board 6 (CB6), specifically the neighborhoods of Turtle Bay, Murray Hill, and Tudor City.

In addition to establishing permanent missions in the New York City area, many member states of the UN and other international states from around the world have also stationed consular offices in the New York City area. 
As mentioned previously, consulates and consuls are not directly involved with the LN. Like permanent missions, consular offices represent and serve the interests of individual countries in the New York (ity area. They are headed by consuls, who are state officials and also part of the diplomatic community. Consuls, like ambassadors, also enjoy the legal privileges and immunities allowed under international law. Currently, New York City hosts the largest consular community in the world and accommodates approximately 99 consular uses (100 in the New York (ity Metropolitan Area). Almost all of the New York City consular offices are located within the boundaries of CB6 and ( B8. The general responsibilities of consulates include cncouraging trade and developing economic ties with the host country, issuing passports and $\checkmark$ isas, and assisting its citizens in the host country.

Since the late 1970's and the early 1980's, numerous new missions and consular use's have been established in the New York City area. As a result of this increased international presence, the need for commercial oflice space, hotel accomnodations, and residential housing has been expanding at a high rate. In addlition, the number of UN System, missions, and consulate cmployees has been increasing. As of 1999, there were approximately 4,570 UN mission employecs and 3,100 consulate cmployeces.

\section{INTERNATIONAL TREATY OBLIGATIONS}

The practice of bestowing privileges and immunities to members of forcign diplomatic missions and consular posts is an old customary norm of international law originating in Ancient Gireece. Through recognising the sovereign equality, irrespective of nations' differing constitutional and social systems, these civil practices are believed to contribute to friendly relations among nations. They are practiced bilaterally throughout the workl, and their reciprocity therefore makes the en effective. They are not granted to foreign oflicials for personal bencfit but for the interest of the UN and the maintenance of international peace and security. Thesc practices are regarded as effective tools that facilitate relations among states and ensure the efficient performance of diplomatic missions. Although diplomatic representatives are excmpt from criminal, civil, and administrative jurisdiction of a receiving state or host state, this exemption is not absolute and they are still under the jurisdiction of their sending state or national state.

As the UN is headquartered in New York (ity, current international law requires the law cnforcement authorities, and administrative and judiciary bodies of the United States to extend certain privileges and immunitics to diplomatic envoys. Although the majority of permanent $U N$ staff members do not have diplomatic status and do not enjoy any special legal privilege or immunity, the Secretary General and the most scnior officials of the UN Sistem, member missions, and consulates pessess diplomatic status. These international rights and obligations are explicitly set forth in the United. Nations Headquarters Agrcement (Public Law 80357 of August 4, 1947), the Convention on the Privileges and Immunitics of the /nited Vations (21 UST 148 (1970)), the Vienna Convention on Diplomatic Relations (23 UST 3227, Public Law 95393 of Lecember 30, 1978), and the International Organizations Immunities Act (Public Law 79-291 of Lecember 29, 1945). A fifth law which is also useful to American businesses or private individluals dealing with forcign governments is the Foreign Sorereign Immunities tot (Pulslic Law 94-583 of September 30, 1978).

Headquarters Agreement- The Headquarters Agreement of August 4, 1947 is a treaty agreement between the UN and the United States that explicitly sets forth the location of the headquarters scat of the UN, the regulations and juriselictional autherity pertaining to that 
district, and provisions for the communication and transit of representatives of members or officials of the UN or other specialized agencies as defined in Article 57, paragraph 2, of the Charter. The Agrecment:

1. Established the location and boundaries of the UN Headquarters District.

2. Established the Headquarters District as inviolable and under the explicit control and authority of the UN.

3. Declared that UN regulations supereede and overrule UIS Federal, state, and loxal regulations within the Hearlquarters I)istrict.

4. Stated federal, state, or local authorities of the US shall not impose any impediments to transit to or from the Headquarters District of representatives of member states or officials of the UN, the families of such representatives, experts pertorming missions for the UN, representatives of the press, and representatives of NGO's recognized by the UIN.

The Convention on the Privileges and Immunities of the United Nations- The Convention on the Privileges and Immunitics of the United Nations is a resolution that was adopted by the UN in February 1946 that provided for the legal rights and privileges of the UN, its property, and its representative members. The Convention:

1. Established that the UN shall possess juridical personality It shall be able to contract, acquire and dispose immoveable and moveable property and institute legal procecedings.

2. Declared that the UN and its property and assets shall enjoy immunity from every form of kegal process, except where it has been waived by the UN.

3. Stated that the UN premiscs shall be inviolable, immune from search, confiscation, expropriation, and any other form of interference, whether by the exceutive, the judicial, or the legislative branches of gowernment.

t. Declared that the representatives of member states to the principal and subsidiary organs of the UIN shall also enjoy immunity from legal processes of every kind while engaged in their capacity as representatives.

Vienna Convention on Diplomatic Relations- The licnna Convention on Diplomatic Relations is a resolution adopted by the UN in April 1961 that described the responsibilities of both the sending and receiving state of diplomatic representatives and officials, and formally codified the privileges and immunities of diplomatic envoys to the UN Headquarters I)istrict. The Convention:

1. Stated that a receiving state can declare any nember of a sending state's cliplomatic stafl a persona non grata without having to justify its decision.

2. Declared that a cliplomatic agent (head of the mission/ a member of the diplomatic staff) is inviolable.

3. Established that a diplomatic agent shall enjoy immunity from the criminal, civil, and administrative jurisclic tion of the receiving state, except in the case where: (a) a real action occurs on the immovable property situated on the territory of the receiving state; (b) an action where the diplomatic agent is involved as an executor, administrator, heir or legatec or private person, (c) an action relating to the commercial or professional activity excreised by the diplomatic agent outside of his/her official functions. 
4. Established that family members and members of the administrative and technical stalf of missions that are not nationals of the receiving state shall enjoy the privileges and immunitics.

5. Declared that it is the duty of all persons enjoying these privileges and immunities to respect the laws and regulations of the receiving state as they have a duty not to interfere in the internal affairs of that state.

International Organizations Immunities Act- The United States International Organization Immunities Act was enacted by the United States Congress on December 29, 1945 to extend certain privileges, exemptions, and immunities to international organizations and to the officers and employees thereof. The Act:

1. Granted International organizations the capacity to contract, acquire and dispese of real property, and to institute legal procecelings.

2. Declared that international organizations, including their property and assets, shall be immune from every form of judicial process, except to the extent that such organizations may waive their immunity.

3. Declared that representatives of forcign governenents in international organizations, an alien officer or employec of an international organization, and the family, attendants, and cmployecs of such a representative are entitled to enjoy privileges, excmptions, and immunities as an international organization under the International Organizations Immunities fict.

4. Stated that no person shall be entitled to the benelits of this Act without the Secretary of State notification and approval. 


\section{INTRODUCTION}

This section considers the land uses, zoning, and neighborhood character in the vicinity of the United Nations Headquarters campus, including the land use trends, zoning, and public plans or policies that may affect land usc patterns in the study area. The purpose of this section is to provide a context for analysis of space utilization patterns by the UN System, permanent missions, and consular corps, as well as to describe the relationship) between the international community and the key characteristics of the surrounding neighborhood. This task involves assessing land use changes in the study area, as well as identifying the study arca's zoning classifications. The neighborhood character assessment provides a brief overview of the communities comprising the study area and their interaction with the UN System, its member missions, and the New York City consular corps.

Since the completion of the UN Headquarters in 1951, the United Nations and other related uses have had a prominent presence in the Kips Bay, Murray Hill, and Turtle Bay neighborhoods, as well as the rest of Community Board 6 (CB6) (sce Figure 2-1). The UN has affected the land use of the immediate area both dircetly and indirectly. The castern edge of Midtown Manhattan has been transformed from a largely industrial area in the 1940's to a thriving residential and commercial/office district today. Indirectly, the presence of the UN has affected the land use of the area, as numerous permanent missions to the UN have selected to establish their offices near the UN Headquarters campus, and as many consular uscs have also located their offices in the arca. This international presence has transformed the area's cconomy and residential composition.

\section{BACKGROUND- HISTORIC LAND USE}

As described carlier, the general study area is defined by the boundarics of CB6 and extends from East $14^{\text {th }}$ Strect on the south to East $59^{\text {th }}$ Strect on the north and from the East River west to Lexington Avenue, and includes a small arca extending west of Lexington Avenue to Madison Avenuc between East $34^{\text {th }}$ and East $40^{\text {th }}$ strects, as well as a small area between East $19^{\text {th }}$ and East $22^{\text {nd }}$ strects from the East River west to Park Avenuc South (sec Figure 2-1). This study area encompasses parts of 10 neighborhoods: Turtle Bay; the Sutton Area Community (SAC); Murray Hill; Tudor City; Kips Bay; Rose Hill; Gramerey Park; the Peter Cooper Village; Stuyvesant Square; and Stuyvesant Town (scc Figurc 2-2).

Throughout much of the mid $19^{\text {th }}$ century, this area of Manhattan remained largely undereloped and primarily housed country estates and farmland. In the late 1800's, however, the landscape was drastically transtormed into a predominantly residential district. Block by block, low-rise, brick brownstones and row houses were crected on a grid street pattern and occupied by the middle and working-class. By the carly 1900's, the arca's conditions changed once again. Much of the East River shoreline was converted into a manufacturing precinct 


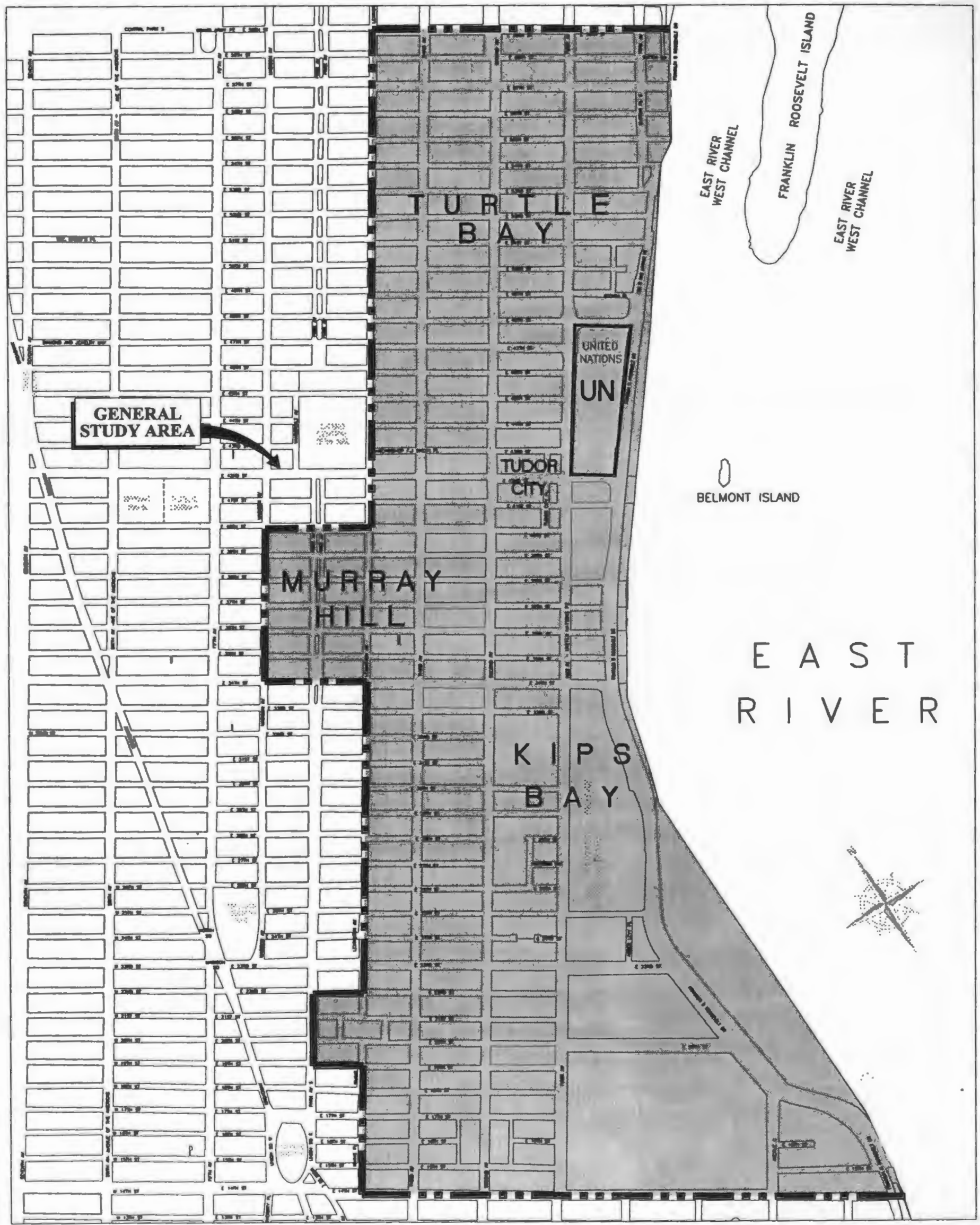



Map of All Neighborhoods and Residential Developments in Community Board 6

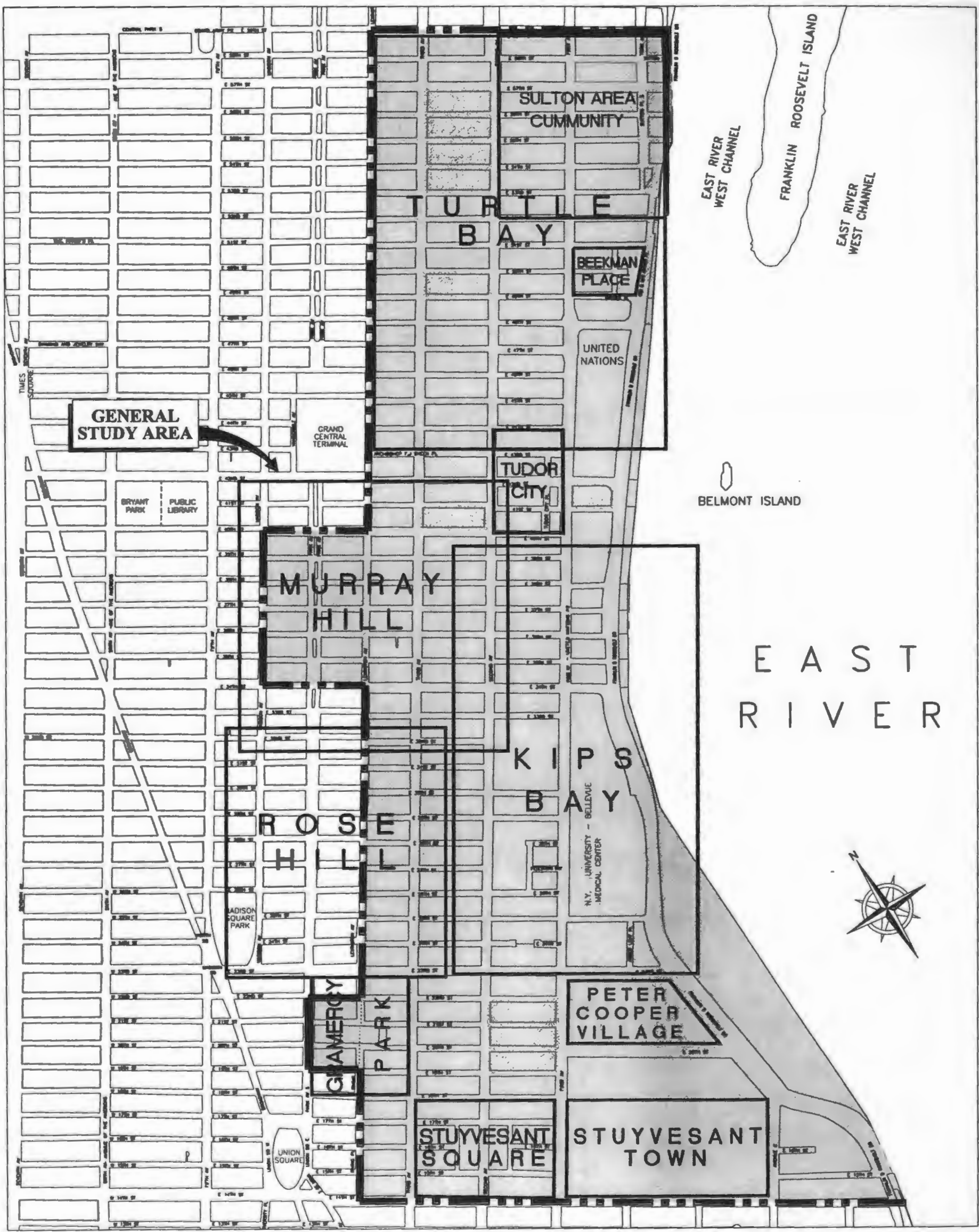


and factorics, warchouses, and brewerics were crected along the casternmost edge of Midtown Manhattan. Waves of immigrant populations brought tenement and boarding houses, and the area began to decline both physically and economically. The site currently occupied by the UN Headquarters campus served as a slaughter house, and much of the surrounding landscape was characterized by blight and tenement housing.

With the removal of the Second and Third avenue elevated rail lines in the late 1940's and carly 1950's, the westerly expansion of Midtown, and the construction of the UN Headquarters campus, the area once again changed significantly. The mid $20^{\text {th }}$ century has brought significant revitalization, and the once deteriorating industrial landscape of castern Midtown is now a thriving eclectic mix of uses.

CB6 is a densely populated mixed-use area that serves as the home to numerous office, institutional, hotcl, and residential uses, as well as some commercial uses. High-rise office buildings, hotels, and retail shops line many of the sites along the north-south avenues of $\mathrm{CB} 6$, and a cohesive mix of low-rise row houses/town houses and high-rise apartment/co-op/condominium buildings line the cross-town strects and mid-block sites. CB6 is home to the UN Headquarters campus, numcrous permanent missions and consular uses, six major hospitals, several universities, and a number of religious institutions.

Currently, CB6 has approximately 136,100 residents that represent 8.8 percent of the total population of Manhattan (sce Table 2-1). In 1989 the median income of CB6 was approximately $\$ 45,900$, about $\$ 16,000$ more than the median income of all of New York City.' In 1999, 3.2 percent of the total population of CB6 received some type of income support, as compared to 18.7 percent of the total population of Manhattan which received some type of aid.?

Like the population of CB6, the total number of housing units and the total number of occupied units have also been increasing (sec Table 2-2). According to the 2000 Census, there were approximately 91,200 housing units within CB6. Of these 91,200 units, 8.2 percent of the housing units were racant and over 83,700 units were occupied. Although CB6 has a slightly higher vacancy rate than Manhattan and New York City as a whole, CB6 has a higher percentage of owner-occupied units than all of Manhattan. The total number and percent of renter occupied units have been declining in CB6 since the 1980's $(91.9 \%$ in $1980,75.6 \%$ in 1990 , and $73.8 \%$ in 2000). Most of CB6, however, is still comprised of renter occupied units (73.8\%).

\section{EXISTING CONDITIONS}

CB6 occupics 1.4-square miles along the castern edge of Midtown and is comprised of approximately 2,900 City Tax Lots. This area of Manhattan is predominantly characterized by a diverse mix of residential uscs. More than 26 percent of the total land use in CB6 is one to two family or multi-family residential uses, and approximately 29 percent is a mix of residential and commercial uses. Very few industrial sites and racant lots remain within CB6. Less than one percent of the land use in CB6 is comprised of industrial or manufacturing uses and less than two percent is vacant land. Commercial office and institutional uses, however, are scattered throughout $\mathrm{CB} 6$ and comprise more than 30 percent of the land use.

1 Census lookup tables, http://venus.census.gov/cdrom/lookup.

2 Department of City Planning. Community District Needs for Manhattan Fiscal Year 2001 \& 1990 
Table 2-1: General Population Characteristics of CB6 as Compared to New York City \& the Borough of Manhattan

\begin{tabular}{|c|c|c|c|c|c|c|c|c|c|c|c|}
\hline & \multicolumn{3}{|c|}{ Total Population } & \multicolumn{2}{|c|}{ Percent Change } & \multicolumn{3}{|c|}{$\begin{array}{c}\text { Percent of } \\
\text { New York City }\end{array}$} & \multicolumn{3}{|c|}{ Percent of Manhatlan } \\
\hline & $1980 *$ & $1990 *$ & $2000 * *$ & 1980 to 1990 & 1990 to 2000 & 1980 & 1990 & 2000 & 1980 & 1990 & 2000 \\
\hline New York City & $7,071,639$ & $7,322,564$ & $8,008,278$ & $3.5^{\circ} n$ & $9.4 " 1$ & $100^{\circ}$ & 10()$^{n}$ & $1000^{13}$ & $\therefore / A$ & $x / A$ & NA \\
\hline Manhattan & $1,+28,285$ & $1,487,536$ & $1,537,195$ & +.100 & $3.3^{10} 1$ & $20.2^{110}$ & $20.3^{\circ} \mathrm{in}$ & $19.2^{\prime \prime \prime}$ & $10(1)^{10}$ & $100 n_{0}$ & $1000^{13}=$ \\
\hline $\begin{array}{l}\text { Community } \\
\text { Board \#6 }\end{array}$ & 127,554 & 133,748 & 136,152 & $4.9 \%$ & $1.8 \%$ & $1.8 \%$ & $1.8 \%$ & $1.7 \%$ & $8.9 \%$ & $9.0 \%$ & $8.8 \%$ \\
\hline
\end{tabular}

Sisurses:

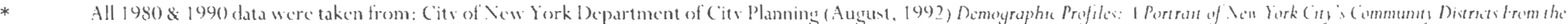

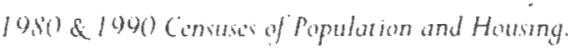

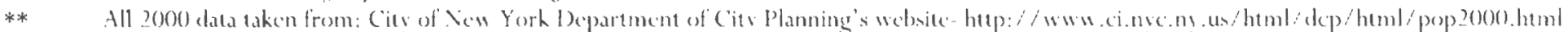

Table 2-2: Housing Characteristics of CB6

\begin{tabular}{|c|c|c|c|c|c|c|c|c|c|c|c|c|}
\hline & \multicolumn{3}{|c|}{ Total No. of Housing Units } & \multicolumn{3}{|c|}{$\begin{array}{c}\text { Percent of Vacant Housing } \\
\text { Units }\end{array}$} & \multicolumn{3}{|c|}{ Total No. of Occupied Units } & \multicolumn{3}{|c|}{$\begin{array}{l}\text { Percent of Renter Occupied } \\
\text { Units }\end{array}$} \\
\hline & $1980 *$ & 1990 * & $2000 * *$ & 1980 & 1990 & 2000 & 1980 & 1990 & 2000 & 1980 & 1990 & 2000 \\
\hline $\begin{array}{l}\text { New York } \\
\text { City }\end{array}$ & $\therefore 941,860$ & $2,992,169$ & $3,200,91 ?$ & $5.2 \mathrm{~m}_{\mathrm{N}}$ & $5.8^{\circ}$ & $5.6^{110}$ & $2,788,530$ & $2,819,+01$ & $3,0) ? 1,588$ & $76.6^{\circ \prime \prime}$ & $71.4^{\prime \prime \prime}$ & $65.9^{\circ} 0$ \\
\hline Manhatian & $75+.+16$ & $785,1 ? 7$ & $798,14+$ & $6.6^{10}+3$ & $8.8 * 4$ & $7.5^{10} 13$ & $70+, 502$ & $716,+?$ & $738,6+4$ & $4 \geq .30$ & $83.1^{1 n}$ & $79.99^{\prime \prime \prime}$ \\
\hline $\begin{array}{l}\text { Community } \\
\text { Board \#6 }\end{array}$ & 84,759 & 92,829 & 91,189 & $5.5 \%$ & $10.4 \%$ & $8.2 \%$ & 80,062 & 83,151 & 83,740 & $91.9 \%$ & $75.6 \%$ & 73.8111 \\
\hline
\end{tabular}

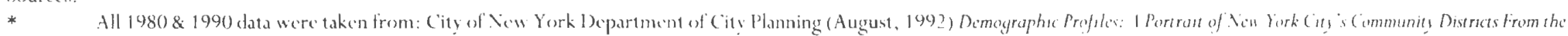
1980 \& 1990 Consuscs of Population and Housing

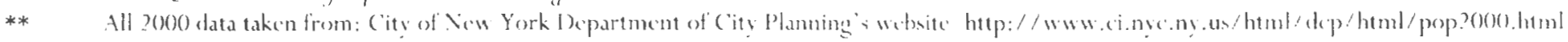




\section{A. Methodology}

As the study area covers more than 875 -acres and is defined by the boundarics of CB6, certain parameters were established to conduct an in-depth analysis of land use trends. Although the entire study area was craluated with regard to the UN System and international community presence (i.e. permanent missions, consulates, and NGO's), a smaller, more managcable arca was defined as the primary study area for a detailed land use analysis. The primary study arca, which encompasses the UN Headquarters campus, was selected based on the apparent concentration of the UN Secretariat, the UN's specialized agencies, UN funds and programmes, permanent missions, and to a lesser extent, consular uses, within portions of the Turtle Bay, Tudor City, Kips Bay, and Murray Hill areas. For example, 155 of the 188 permanent missions to the UN (approximately 82\%), and 63 consulates (approximately 63\%) were identified within the primary study area. As shown in Figure 2-3, the primary study area is defined as the area bordered by East $53^{\text {ril }}$ Strect to the north, Lexington Avenue to the west, East $34^{\text {th }}$ Strect to the south, and the East River to the cast.

The current land use and neighborhood character were determined by site visits, 1980 and 1990 Department of City Planning Land Use Maps, 2000 Sanborn Maps and the Department of City Planning's Primary Land Use Taxlot Ouput (PLUTO) files, as well as the Department of Finance Real Estate Tax Records.

\section{B. Land Use}

At the turn of the $20^{\text {th }}$ century, the study area predominantly scrved as a major industrial center. During the early 1900's, there were a number of manufacturing workshops, stockyards, and other industrial cntitics located throughout the area. With the establishment of the UN Headquarters in 1951, however, the area drastically changed and began to accommodate a variety of uses. The study area has been essentially transformed into a mix of residential, institutional, and office uses, with some commercial retail and service uses. Within the past few decades, there have also been a series of land use changes in the area extending from East $34^{\text {th }}$ to East $53^{\text {rd }}$ strects between the FDR and approximately Lexington Avenue.

\section{The General Study Area}

The general land use study area covers most of the eastern edge of Midtown from East $59^{\text {th }}$ to East $14^{\text {th }}$ strects, from Lexington Avenue to the East River, as wcll as a small area between East $40^{\text {th }}$ and East $34^{\text {th }}$ strects from Madison Avenuc to the East River and a snall area between East $22^{\text {nt. }}$ and East $19^{\text {th }}$ strects from Park Avenuc South to the East Rirer (sce Figure 2-3). It includes such significant buildings as the UN Secretariat building, the UN General Assembly building, Bellevue Medical Center, the New York University Hospital, the Citicorp Center, and the Chrysler Building. Overall, this arca of Midtown is generally less developed than the central commercial core of Midtown, and is largely defined by its distinct residential neighborhoods and large institutional uses. Within this overall area there is a range of neighborhoods and districts, each with its own unique character, including the residential neighborhoods of Turtle Bay, the Sutton Arca Community (SAC), Murray Hill, Tudor City, Rose Hill, Kips Bay, Gramercy Park, Stuyvesant Square, Stuyvesant Town, and the Peter Cooper Village (sce Figure 2-2), and the commercial corridors of Lexington and Third asenues, and East $42^{\text {nd }}$ Strect.

Generally, commercial, retail, hotel, and office uses are predominantly concentrated inland towards the center of Manhattan and line Lexington and Third avenues and East $42^{\text {nd }}$ Strect, while residential uses are located closer to the East River between First and Second avenues, lining cross-town strects. Institutional and public facility uses including the UIN, hospitals, permanent missions, consular uses, and universitics, however, are scattered throughout CB6. The UN Headquarters, UN's specialized agencies, UN programmes and funds, 


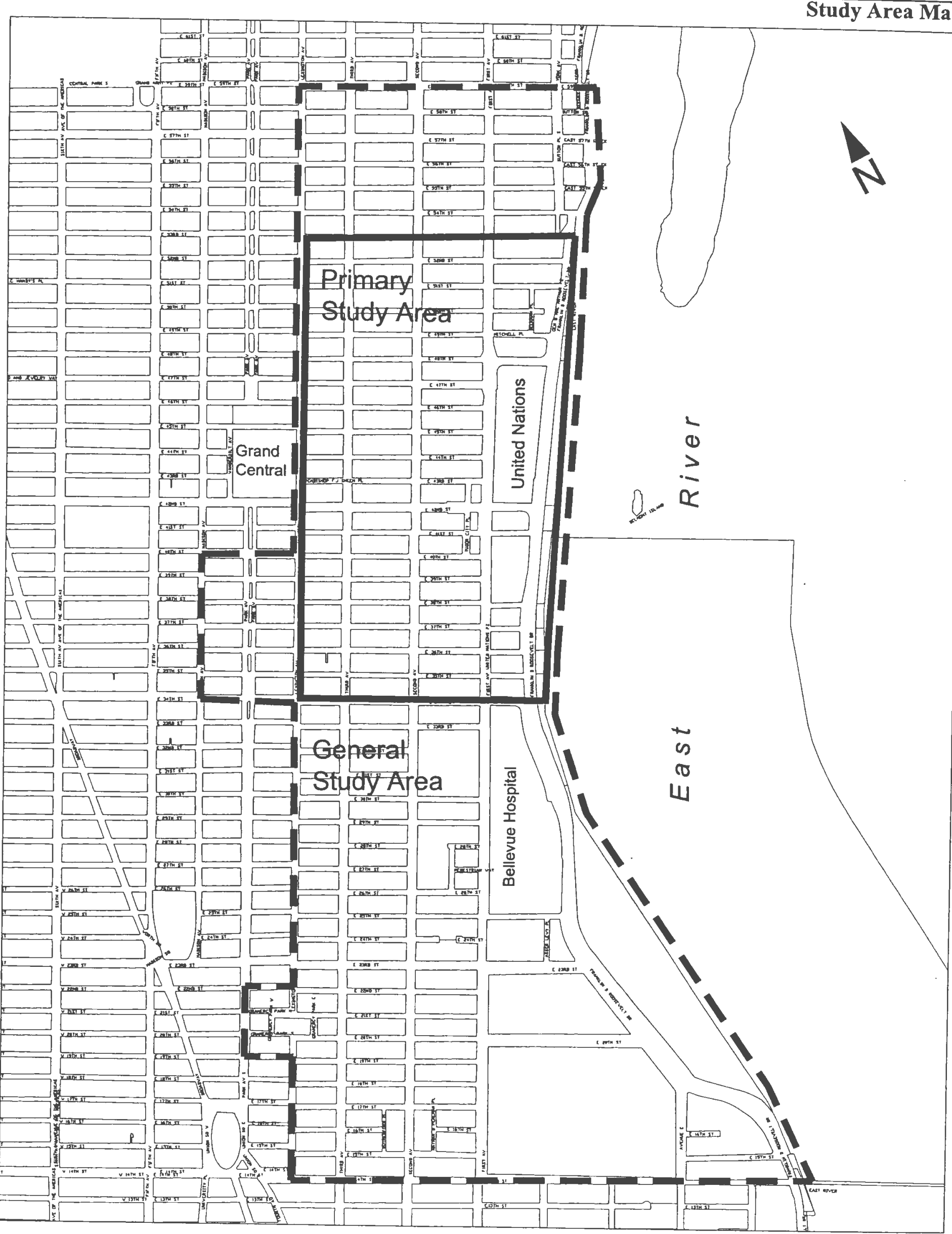


permanent missions, and consular uses are largely located within the northeastern section of CB6 within the neighborhoods of Turtle Bay, Tudor City, Murray Hill, and Kips Bay. The Bellerue Medical Center, the New York University Hospital, Stern College for Women, and CUNY Baruch College are located within the southern portion of CB6 and dominate the neighborhoods of Kips Bay, Rose Hill, and Gramercy Park.

Very few industrial areas and vacant parcels are located within CB6. The few remaining industrial sites are situated along the East River between East $35^{\text {th }}$ and East $41^{\text {t }}$ strects and along East $14^{\text {th }}$ Strect. Parks and opern space arcas are also dispersed throughout CB6. Some of the larger parks in CB6 are St. Vartan's Park, located along First Avenue between East $42^{\text {nid }}$ and East $43^{\text {rd }}$ strects, Stuyvesant Square, situated on Rutherford Place between East $15^{\text {th }}$ and East $17^{\text {th }}$ strects, John J. Murray Park, located on East $17^{\text {th }}$ Strect between Avenuc C and the FDR Drive, and Peter Detmold Park, situated along the west side of the FDR Drive between East $49^{\text {th }}$ and East $51^{\text {st }}$ strects. Although open space areas and public parks are prevalent throughout nuch of $\mathrm{C} B 6, \mathrm{CB} 6$ has less park space per capita than most parts of New York City.

\section{The Primary Study Area}

Figures 2-4, 2-5, and 2-6 illustrate the primary study area's generalized land use in 1980, 1990, and 2000. As all three figures illustrate, the primary study area has remained a relatively stable area with minimal vacant or underutilized space. Residential uses have dominated the area since the 1980's and are largely concentrated in the northcast in the Turtle Bay, SAC, Beckman Place, Tudor City, and Murray Hill neighborhoods and in the south in the Gramercy Park, Stuyvesant Park, Peter Cooper Village, and Stuyvesant Town neighborhoods, along the mid-block areas of cross-town strects. Commercial, office, and institutional/public facility usces, however, have been expanding in the area since the 1980's. Small areas of resickential use and significant areas of industrial use are rapidly being converted into comnercial, office, and institutional/public facility uses. Office and commercial uses have largely been expanding and converting residential uses along the avenue corridors of Third, Lexington, and Sccond avenues, and along major cross-town strects, such as East $34^{\text {th }}$ and East $46^{\text {th }}$ strects. As Figure 2-6 shows, Lexington and Third arcnues and East $42^{\text {mlt }}$, East $43^{\text {rd }}$, East $44^{\text {th }}$, and East $45^{\text {th }}$ strects are currently the central commercial, office, and public facility corridors of the area.

Many of the industrial areas in the 1980's and 1990's along the East River between East 41 "and East 34" strects have also been converted into large areas of institutional/public facility uses. In acklition, small pockets of residential areas north of East $41^{\text {st }}$ Strect and east of Second Avenuc (especially along First Arenue) have been converted into institutional/public facility uses. As shown in Figure 2-6, institutional/public facility uses are largely concentrated in areas along the East River between East $34^{\text {th }}$ and East $48^{\text {th }}$ streets in the neighborhoods of Murray Hill, Tudor City, and Turtle Bay, encompassing the UN Headquarters. The four largest remaining industrial sites, located between East $35^{\text {th }}$ and East $41^{\text {th }}$ strects and Second Avenue and the FDR Drive, have becn sold by Con Edison and are anticipated to be converted into office, residential, and/or public facility uses in the near future. Currently, all four sites are unutilized and vacant. They are the largest tract of "undercloped" land within Midtown, and represent some of the most significant potential for future commercial/residential development in the comnunity district.

The primary study arca's public parks have remained largely unchanged throughout the 1980's and 1990's. Growing only slightly, public parks are located throughout the landscape and vary in size from the size of neighborhood lots to screral city blocks. Some of the parks in CB6, including CB6's largest park, St. Vartan's Park have undergone significant upgrades and improwements in recent ycars.

Table 2-3 summarizes the changes in land use classifications in the area by comparing the estimated percentage of land (lot arca) in 1980, 1990, and 2000 occupied by various uses. Permanent missions, consulates, and UN 


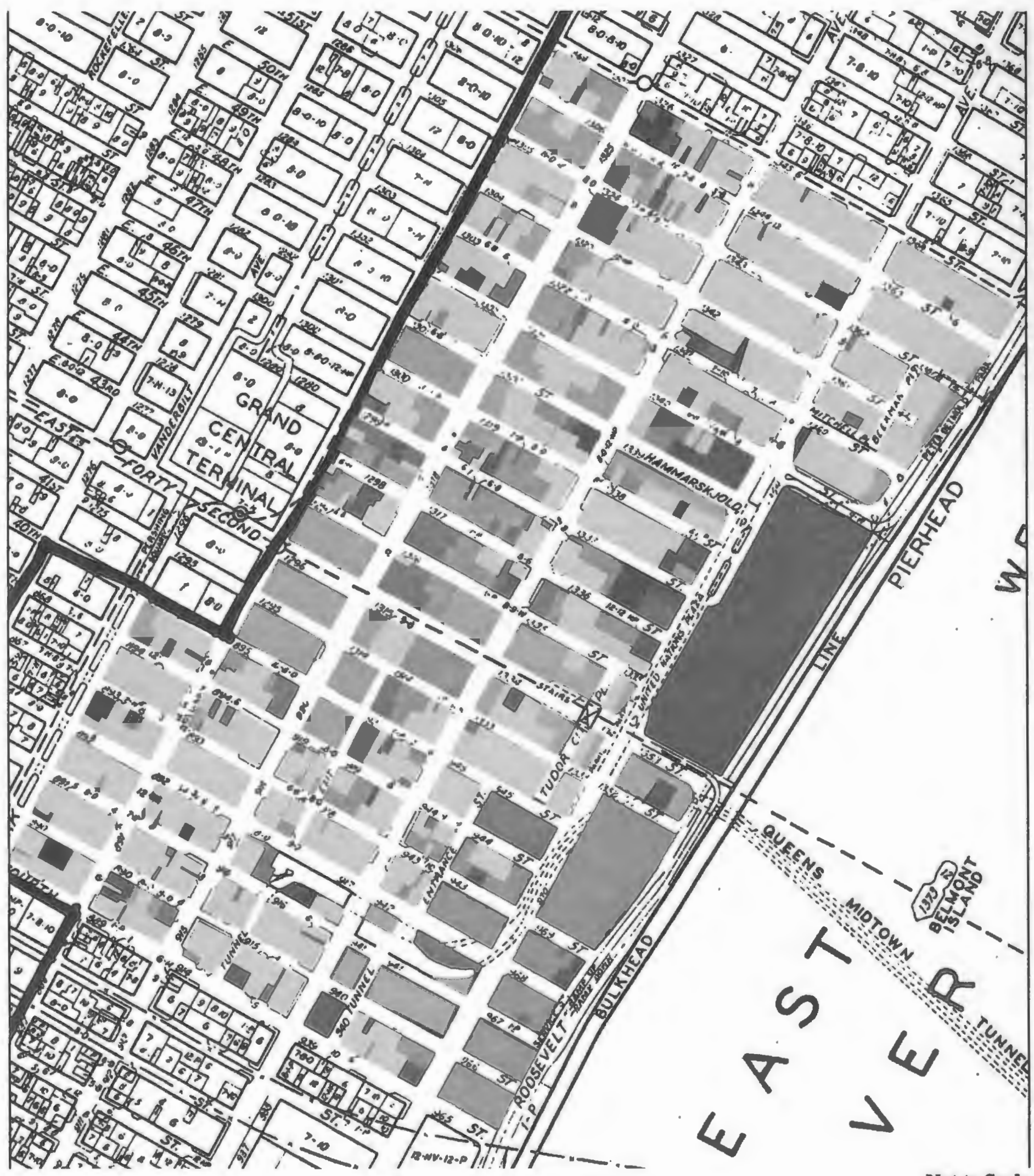

Not to Seale

Residential Ure

Parka/ Open Space
Commercial Use

Vacant Space
Public Facilities \& Institutional Use

Industrial Use

Ofilice Use 


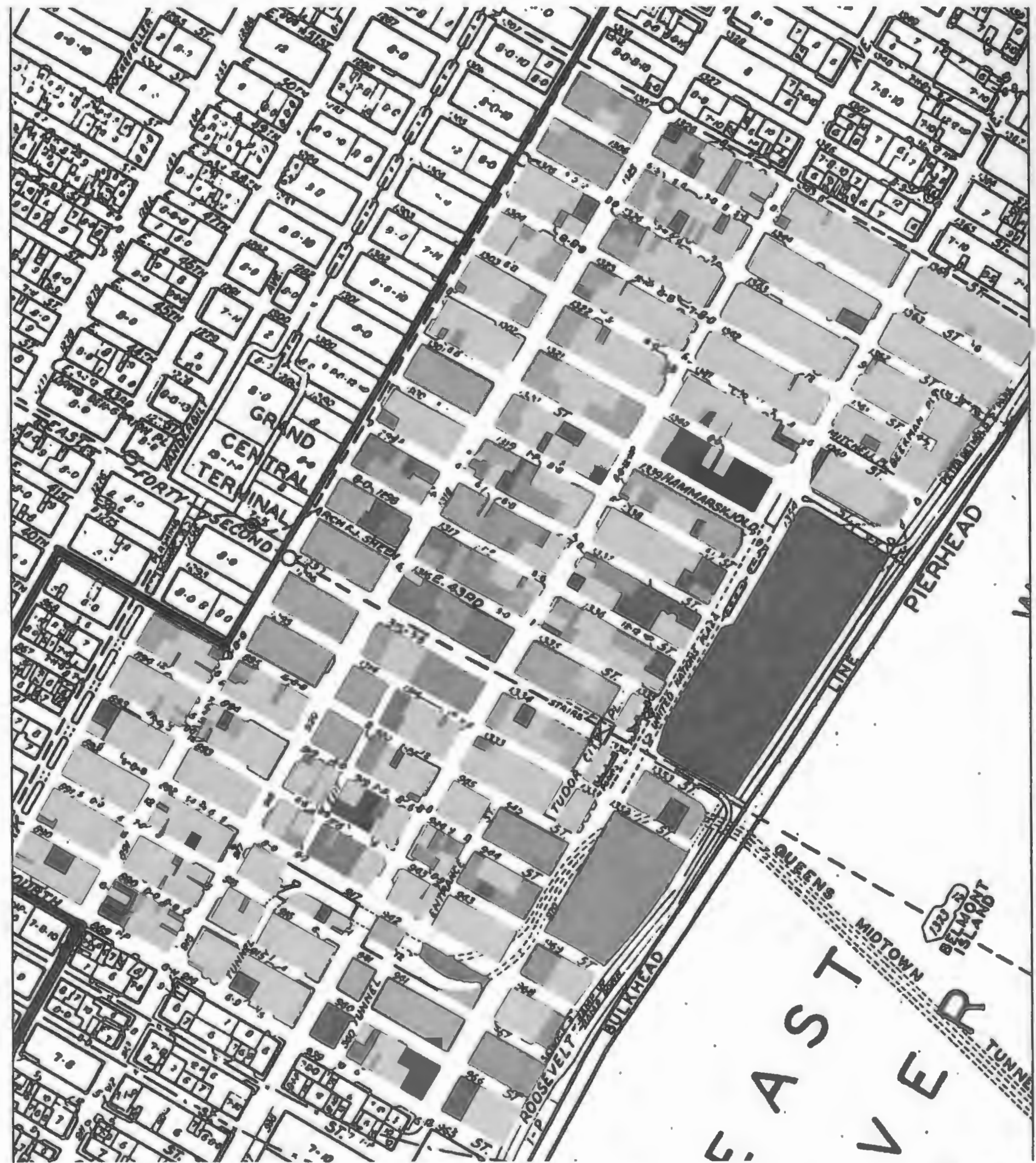

Not to Scale

Reaidential Use

Parka/ Open Space
Commercial Use

Vacant Space
Public Facilities \& Institutional Use

Industrial Use 


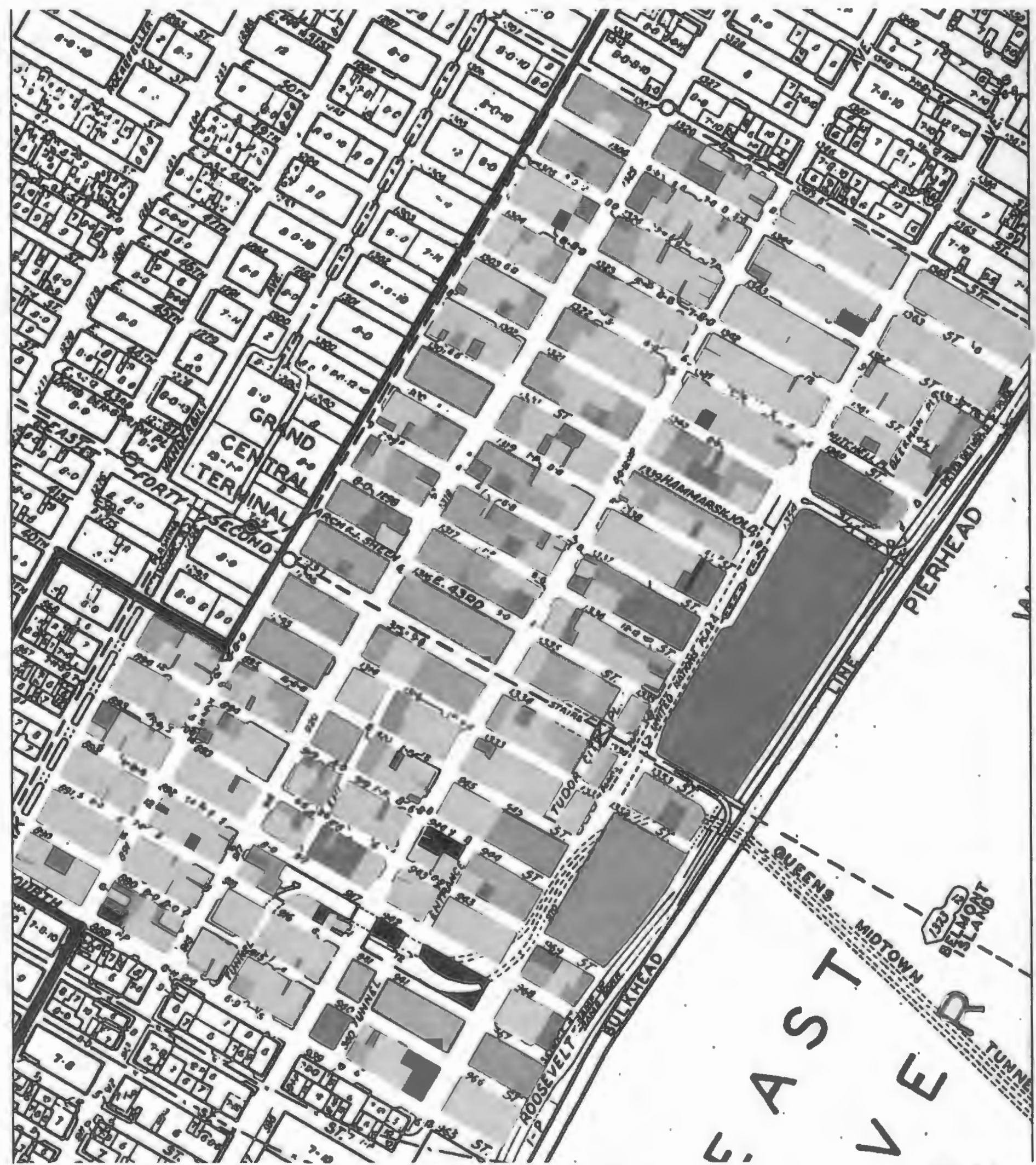

Not to Scale

Residential Uce

Parkel Open Space
Commercial Use

Vacant Space
Public Facilities \& Institutional Use

Industrial Use 
System-related uses are classified and included as public facilities and institutional uses. As shown in Table 2-3, the amount of land classified as industrial uses continues to decrease, declining from approximately 14 percent in 1980 to less than one percent in 2000. The former Con Edison facilities located just south of the UN Headquarters, abutting the FDR Drive represent the largest portion of these industrial uses within the area. In contrast, reflecting the shift in the cconomy, the amount of land utilized for office use has nearly doubled from 13 percent in 1980 to 26 percent in 2000. The amount of land occupied by public lacilities and institutions has also increased slightly. Residential land uses, howerer, still remain the dominant land use within the study area, at 40 percent in 2000. Commercial uses have also fluctuated since 1980, dropping from 8.0 percent in 1980 to less than 5 percent in 1990, to approximately 7 percent in 2000. The other land use classifications, parks and vacant land, have remained relatively stable throughout the past few decades.

Table 2-3: Land Use Percentages in CB6

\begin{tabular}{|c|c|c|c|}
\hline Land Use Classification & $\underline{1980}$ & 1990 & $\underline{2000}$ \\
\hline Residential & $+5.0 \%$ & $49.0^{\circ} \%$ & $40.0^{\circ}$ \\
\hline Office & $13.0 \%$ & $14.0^{\circ} \%$ & $26.0^{\circ} \%$ \\
\hline Public Facilities \& Institutions & $14.0^{\circ} \%$ & $15.0 \%$ & $19.0^{\circ} \circ$ \\
\hline Industrial & $14.0^{\circ} \%$ & $11.0^{\circ} \%$ & $1.0^{\circ} 0$ \\
\hline Commercial & $8.0^{\circ} \%$ & $5.0^{\circ} \%$ & $7.0 \%$ \\
\hline Parks & $4.0^{\circ}{ }_{0}$ & $+.0^{\circ}$ & $4.00^{\circ} \circ$ \\
\hline lacant & $2.0^{0} \cdot$ & $2.0^{\circ} 0$ & $3.0^{\circ} 0$ \\
\hline
\end{tabular}

\section{Zoning}

CB6 is composed of a mix of primarily high to moderate density residential and commercial zoning districts. $R$. $7, \mathrm{R}-8$, and $\mathrm{R}-10$ residential districts and $\mathrm{C} 1, \mathrm{C} 5$, and $\mathrm{C} 6$ commercial districts dominate the landscape. Figure 2-7, shows a map of the zoning districts that comprise $\mathrm{CB} 6$ and the previously defined primary sturly area. As shown in Figure 2.7, office and commercial zoning districts are largely concentrated around Third Arcnuc and the blocks to the west and along some cross-town streets like East $42^{\text {nd }}$ and East $34^{\text {th }}$ strects. Residential districts are predominantly concentrated to the cast of Third Avenue and along the majority of cross-town strects, although not to the exclusion of significant institutional uses. Some of these notable institutions are the New York University Hospital, the Bellevue Medical Center, and the UN Headquarters campus. The few manufacturing districts that remain are concentrated between First Avenue and the East River from East $35^{\text {th }}$ to East $41^{\text {th }}$ streets and along East $14^{\text {th }}$ Strect. Table $2-4$ provides a detailed breakelown of all the zoning designations included within CB6.

\section{Primary Study Area}

The primary study area is largely compesed of a mix of moderate to high density commercial uses, with $\mathrm{C} 5$, $\mathrm{C} 6$, and $\mathrm{C} 1$ zoning districts dominating the landscape. The arca's $\mathrm{C} 5$ zoning districts are largely located within the southern portion of Turtle Bay, between Fast $+2^{\text {mid }}$ and East $49^{\text {th }}$ strects from lexington Avenuc to the East 


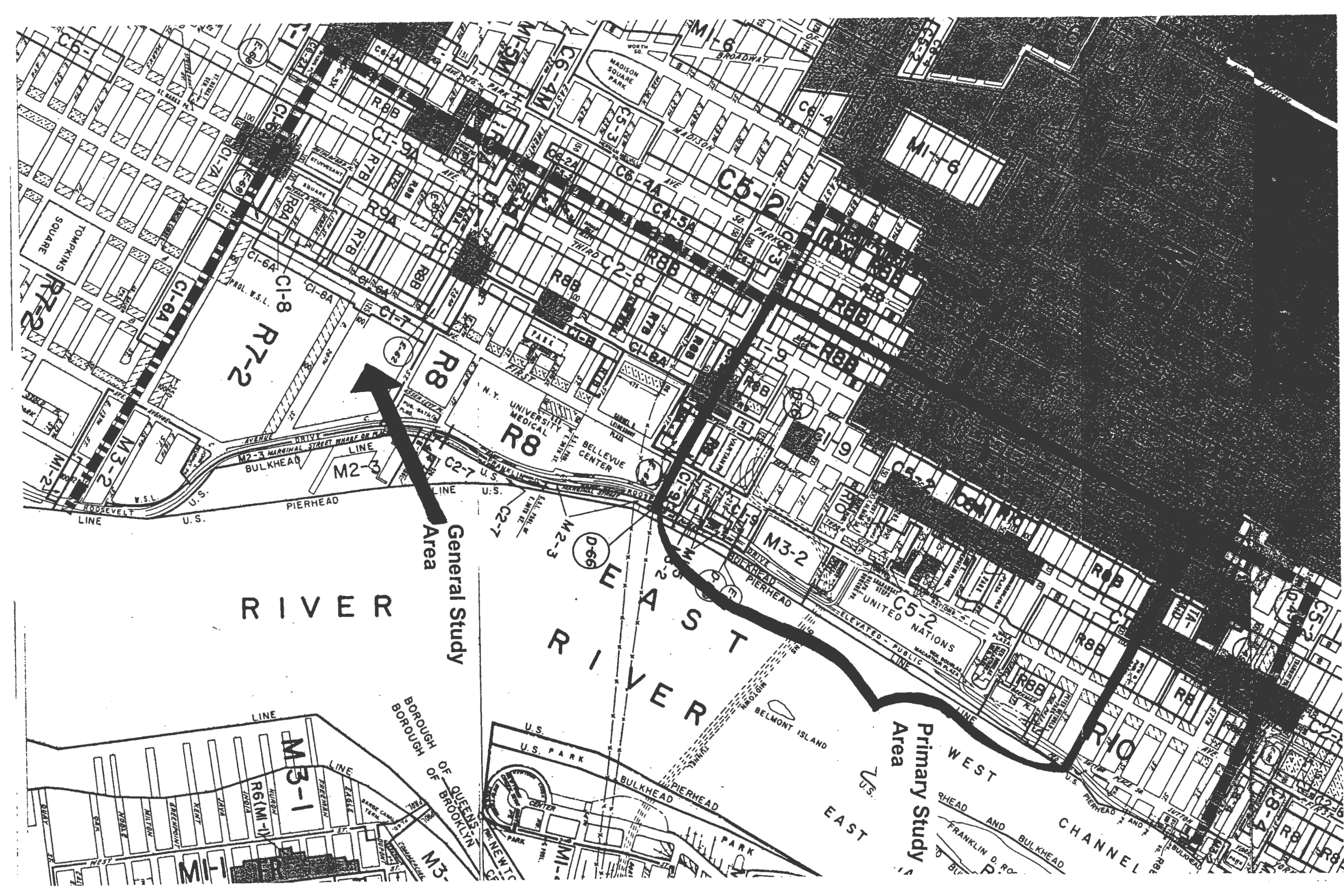


Table 2-4: Zoning Designations in the Study Area

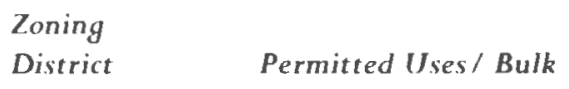

Residential Districts

R-T.R-10 Mid-density residential districts, allowing for tall buildings with kow lon cowrage sed hack trom the street.

$R \& B$

Mid-density residential districts that cncourage high-coverage buildings. A maximum F.AR of +.0 is permitted for residential uses. The front of a building nust occupy the full lot width and align with the frent walls of adjacent buildings.

Commercial Districts

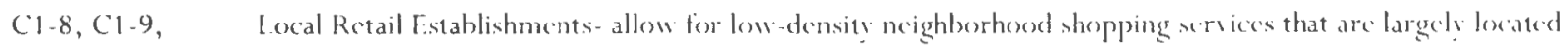
C1-9. adjacent to residential areas and prohibit local scrvice and nanufacturing establishments. Ilse groups 1 through 6 are allowed do of right and a maximum FAR of 2.0 is permitted for commercial deselopments, and a FAR of 10.0 is permitted lor communits facilities.

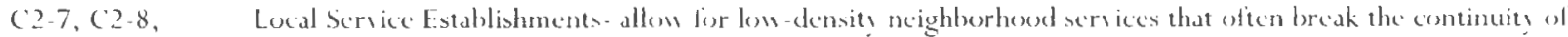
C2 8A prime retail frontage and comenient shopping. Use groups 1 through 9, and $1+$ are allowed an of right, and a maximum FAR of 2.0 is permitted for commercial developments, and a FAR of up to 10.0 is permitted tor communits facilitics.

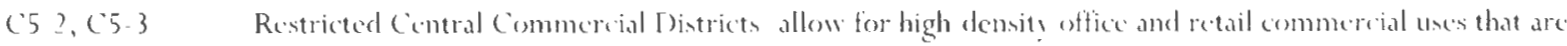
gencrally found in contral husine distriet areas and oce up: the prime retail fremtage in the (13I). Use groups 1 through 6 , and 9 through 11 are allowed as of right and a $\Gamma A R$ of 10.0 is permitted for commercial uses and communit lacilitics (FAR of 15 .0 for $(5-3)$

C6-2A, C6-3, General Contral Commercial Districts- allow for medium to high density office, rerail, and custum

C $6-3 A$ manufacturing commercial uses outside the CBD. Use groups 1 through 12 are allowed as of right, and a IAR of 10.0 is permitted for commercial deselopments (FAR of 6.0 lis $(62 / 3)$ and a FAR of 10.1$)$ is permitted for communits lacilitics (FAR of 7.5 for $(63.1)$

C6-4A, (6-6 General Central Commercial Districts- allow for allow high densits oflice, retail, and custom manufacturing, commercial uses outside the (BГ). Use groups 1 through 12 are allowed as of right, and a FAR of 10.0 is permitted for commercial developments (F.tR of 15.0 for $(6$ 6) and a FAR of 10 ). 1) is perminul for communits facilitics (F.AR of 15.0 for $(6-6)$.

Manufacturing Districts (residential uses prohibited)

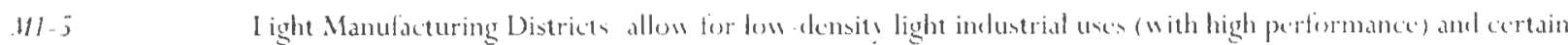
communits facility uses. Use groups t through 14 , and 16 and 17 are allowed an of right and a maximum FAR of 5.0 is permitted for commercial developments, and 6.5 is permitted for community fac ilit! unes.

M2 3 Medium Manufacturing l)istrice allow for medium densits indestrial uses (with moderate pertormanece. Community facilits uses are not purmittod. Use groups 6 through 14 , and 16 and 17 are allowed as of right and a maximum FAR of 2.0 is permitted for commercial dovelopments.

13-? Heas Manufacturing Districts allow for high-density industrial uses awith low performance). (ommunity farilities are not permitted. (Ise sroups 6 through $1+$, and 16 through 18 are allowed an of right and a maxinum I AR of 2.0 is permittid for commercial development.

Special Purpose Districts

MiD Special Midtown District

II Special United Xations Denelopment District

Source: Zoning Resolution of the (its of Xew York 
River, and generally run north-south along the avenues and include such notable institutions as the UN Headquarters campus and the Ford Foundation. C5 districts are Restricted Central Commercial Districts and allow for high-density office and retail uses that are generally found within Central Business District (CBD) arcas and occupy prime retail frontage in the CBD. Use groups 1 through 6, 9, and 11 are allowed as-of-right within $\mathrm{C} 5$ zoning districts, and the FAR for commercial use ranges from 4.0 to 15.0 depending on the use group (a maximum FAR of 10.0 is permitted for community facility uses). The arca's C6 zoning districts are located within the western portion of Turtle Bay just north of the C 5 districts between East $49^{\text {th }}$ and East $56^{\text {th }}$ strects and line Lexington and Third avenues. C6 districts are General Central Conmercial Districts and allow for medium to high density office, retail, and custom manufacturing uses outside of the CBD). Use groups 1 through 12 are allowed as-of-right in C6 zoning districts and a maximum FAR of 10.0 is permitted for commercial and/or community facility uses. C1 zoning districts are located within the Murray Hill and Rose Hill neighborhoods just south of the C5 districts, and line Sccond and Third avenues, as well as part of First Arenue. C1 districts are Local Retail Districts that largely overlay Residential districts and allow for lowdensity neighborhood shopping services that are largely located adjacent to residential arcas. They prohibit local service and manufacturing establishments and are designed to promote convenient shopping and encourage continuous retail frontage. Use groups 1 through 6 are allowed as of right within $\mathrm{C} 1$ zoning districts, and the maximum FAR of a $\mathrm{C} 1$ district is determined by the Residential district within which such Commercial district is mapped. A maximum FAR of 2.0 is permitted for commercial developments in a $\mathrm{C} 1$ district when mapped as overlays in R6 districts and above (a maximum FAR of 10.0 is permitted for community facilities).

Other zoning districts that are found within the primary study area are small pockets of residential (R-8 and $\mathrm{R}$ 8B) and manufacturing (M1-5 and M3-2) districts. R8 residential districts are located within the northeastern corner of the primary study area, within the Turtle Bay, SAC, and Beckman Place neighborhoods, between East $49^{\text {th }}$ and East $53^{\text {rid }}$ streets, cast of Third Avcnuc. R- 8 districts are mid-density residential districts that allow for tall buildings with low lot coverages set back from the street. $\mathrm{M} 3$ and $\mathrm{M} 1$ districts are located in Kips Bay along the East River, between the FDR Drive and First Avenue from East $35^{\text {th }}$ to East $41^{\text {th }}$ strects and inclucke the former Con Edison industrial sites. M1 zoning districts are Light Manufacturing Districts that allow lor low density light industrial uses and certain community facility uses. Use groups 4 through 14 and 16 and 17 are allowed as-of-right within M1 zoning districts, and a maximum FAR of 2.0 is permitted for commercial developments. M3 zoning districts are Heavy Manufacturing Districts that allow for high-density industrial uses. Community Facilities are not permitted in M3 districts. Use groups 6 through 14 and 16 through 18 are allowed as-of-right within M3 zoning districts, and a maximum FAR of 2.0 is permitted for commercial development.

\section{Special United Vations Development District}

Also included within the primary study area, is the Special United Nations Development District. Located directly west of the UN Headquarters campus on significant portions of two City blocks between East $43^{\text {rd }}$ and East $45^{\text {th }}$ streets, the United Nations Development District was created to protect and promote the City of New York as a center for international organizations and as an office headquarters, as well as a cosmopolitan residential community. Through encouraging the provision of suitable office, meeting, and conference facilities, hotel accommodations, and housing for the UN System, permanent missions, and non-governmental organizations (NGO's) related to the UN, in the immediate vicinity of the UIN Headquarters campus, this special purpose district is clesigned to maintain New York City's pre-cminent status as a world city, and assure the retention of the UN Headquarters in New York City. This special overlay district is designed to promote the coordinated rederelopment of the area contiguous to the UIN Headquarters campus. Flexible architectural design guidelines, floor arca bonuses, and use modifications of the underlying zoning regulations are intended 
to facilitate the continued grow th of the programs and activities of the UN System, permanent missions, and NGO's in the vicinity of the UN Headquarters campus.

\section{General Study Area}

As mentioned above, CB6 is a mix of residential, institutional/public facility, office, and commercial uses. Residential areas and R-7, R-8, and R-10 zoning districts are predominantly located north of East $43^{\text {ril }}$. Strect, along the East River, south of East $35^{\text {th }}$ Street, and along the cross-town strects or the micl-block areas. These zoning districts include such notable residential communitics as Stuyvesant Town, Stuyvesant Park, Gramercy Park, Tudor City, Murray Hill, SAC, and Beckman Place and allow for mid-density residential developments. Also included within these zoning districts are such notable institutions as the New York University Hospital and the Bellevue Medical Center.

Commercial arcas and $\mathrm{C} 1-9, \mathrm{C} 2-8, \mathrm{C} 5.2$, and $\mathrm{C} 66$ zoning districts are generally located along avenue corridors and along major cross-town strects such as East $42^{\text {mit }}$, East $34^{\text {th }}$, and East $23^{\text {ril }}$ strects. $\mathrm{C} 5-2$ and C6-6 are high-density commercial zoning districts that allow for a wide range of high bulk commercial uses, including department stores, large office buildings, hotels, and mixed-use buildings. They are generally located north of

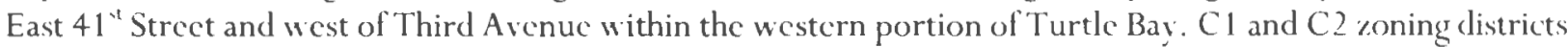
are designed to serve local retail and service needs of the residential community. They allow for low density commercial retail and office developments and are located throughout CB6 along the avenue corridors and major cross-town strcets.

Special Midtown District

As illustrated in Figure 2-7, CB6 also includes the castern edge of the Special Micltown District (MiD). The special purpose Midtown District covers most of Midtown, extending from approximately. $58^{\text {th }}$ Strect in the north to $39^{\text {th }}$ Strect in the south and from Eighth Avenue on the west to Third Avenue on the cast (sec Figure 2 8). In addition to the underlying zoning of the area, this special purpose districts was created to strengthen the business core of Midtown and expand and cnhance the pedestrian circulation network connecting Grand Central Terminal to the surrounding development. Established in 1998, the Special Micltown 1District was created to further stabilize development in Midtown by providing direction and incentives (e.g. floor area bonuses) for appropriate grow th and development in the area. Through improving both the living and working environments of Midtown, the Special Midtown District is intended to preserve the historic character of development, encourage relatively low building bulk in mid-block locations, as compared to avenuc frontages, and improve the pedestrian orientation of ground floor uses. This special purpose district is also intended to improve the quality of new development through improving pedestrian access and circulation, fostering the provision of specific public amenities, and controlling the impact of buildings on the access of light and air to the strect.

\section{Neighborhood Character}

As discussed above, CB6 is largely comprised of a mix of residential, institutional, office, and commercial uses (sce Table 2-3) and contains such notable features/structures as the UN Headquarters campus, the New York University Hospital, and the Bellerue Medical Center, and distinguished residential areas as SAC, Beckman Place, Tudor City, Stuyesant Town and the Peter Copper Village. This 875 acre arca on the castern side of Midtown also includes the neighborhoods of Turtle Bay, Murray Hill, Kips Bay, Stuyesant Square, and Gramercy Park (sec Figure 2-2). Each area is discussed bricfly below. 
Assessment of the Future Office Space Needs of the International Community Figure 2-8 Special Midtown District and Grand Central Subdistrict

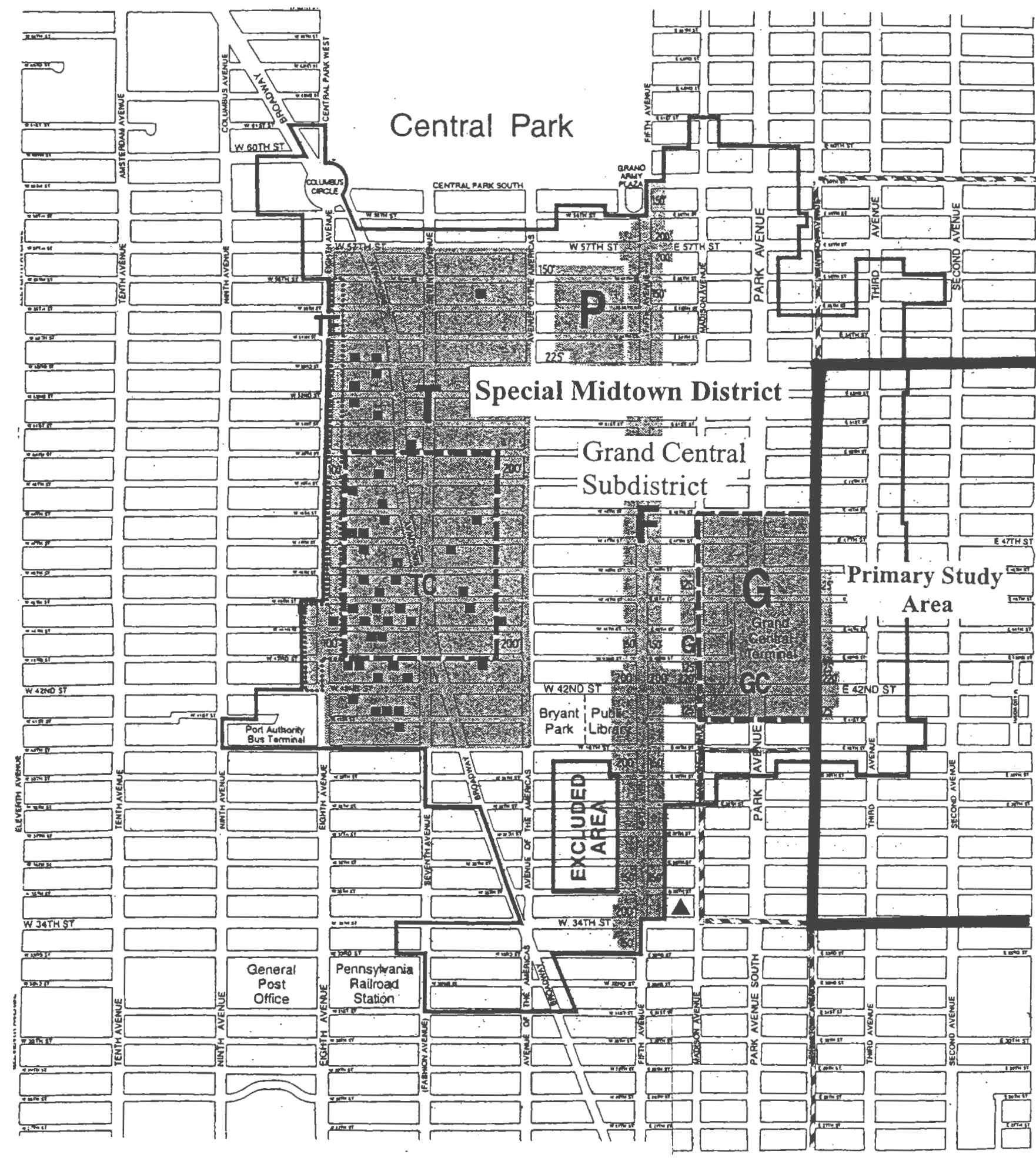




\section{Turtle Bay}

Turtle Bay first originated as a 68 -acre farm and has since experienced a boom of unprecedented growth. After the Civil War, the pastoral landscape was slowly converted into brownstone buildings, while the once glorious waterfront became an industrial precinct. Waves of immigrants poured into the area and transformed the shoreline of Turtle Bay into a home of tenements and rooming houses. The 1920's however, brought ambitious renovation to the area and restored many of the brownstones into fashionable townhouses and created large communal gardens. Today, the area is a mix of residential buildings, office, and retail space.

Turtle Bay is a 40-acre district located within the northern section of CB6, just north of the Chrvsler Building and the commercial corridor of East $42^{\text {nd }}$ Strect. It is bounded by East $59^{\text {th }}$ Strect to the north, Lexington Avenue to the west, East $43^{\text {ril }}$ Strect to the south, and the East River to the east, and cncompasses such notable residential arcas as Beckman Place and SAC. In addition, the area also contains such noteworthy structures as the 59-story Citicorp building on the corner of Lexington Avenue and East $53^{\text {rl }}$ Strect, and the 39- and 40-story office towers of One and Two UN Plaza along East $44^{\text {th }}$ Street. Turtle Bay is home to the largest concentration of member missions to the UN and consular offices in the City, approximately 86 permanent missions and 35 consular offices are located within Turtle Bay. The arca also contains several small parks including Greenacre Park along East $51^{\text {"N }}$ Street between Third and Sccond avenues, Peter Delmold Park along the FDR Drive between East $51^{t t}$ and East $49^{\text {th }}$ strects, Douglas MacArthur Playground just one block south of the Peter Delmold Park, Dag Hammarskjold Park along East $47^{\text {th }}$ Strect between First and Second arenues, and Ralph Bunche Park along First Avenue between East $43^{\text {rd }}$ and East $42^{\text {ndd }}$ strects.

\section{The Sutton Area Community (SAC)}

The area that comprises the current Sutton Area Community originated as a vacation retreat for the wealthy. During the mid-1800's, this area underwent a major transformation and much of the East River shoreline was converted into an industrial precinct. Several factories, warchouses, and breweries encroached upon the once pastoral landscape. After the Civil War, Effingham B. Sutton, a real estate speculator, acquired several City blocks and slowly revitalized some of the area. He gave the neighborhood a new image and a new name. Numerous small low-rise, brick row houses were erected for the middle and working class. The early 1900's and the Great Depression, however, brought significant economic decline to the area and many of the midelle class residents left. Not until the mid 1900's did the area experienee significant redevelopment and gentrification. Today, SAC is a thriving apartment district with a cohesive mix of high-rise apartments and (o)ops, and low-rise row houscs.

The Sutton Arca Community is a small residential enclave located within the northeastern corner of CB6 just south of the Qucensboro Bridge. It is generally bounded by East $59^{\text {th }}$ Street to the north, Second Avenue to the west, East $52^{\text {nd }}$ Strect to the south, and the East River to the cast. The area contains such distinguishing structures as the Archdiocese of New York at 1011 First Avenue between East $55^{\text {th }}$ and East $56^{\text {th }}$ strects. There is currently only one permanent mission and one consular office located within SAC.

\section{Murray Hill}

Also originating as the home of several large country estates, this prominent neighborhood has remained a relatively stable affluent residential neighborhood comprised of luxury brownstones, row houses, and apartment buildings. Presently, Murray Hill is less densely cleveloped than the rest of Midtown and is the home of numerous high-rise apartment buildings, churches, clubs, and restaurants. There is also ground floor neighborhood retail scattered throughout the arca. 
Murray Hill is a unique residential neighborhood located just south of Grand Central Station, northeast of the Empire State Building, and east of the Tudor City Village. It is bounded by East $42^{\text {nd }}$ Street to the north, Madison Avenue to the west, East $32^{\text {nd }}$ Strect to the south, and Sccond Arenue to the east. It is the home of such significant structures as the Pierpont Morgan Library and Annex at 2933 East $36^{\text {th }}$ Street, and the Chanin Building at 122 East $42^{m d}$ Strect. It also includes two historic districts designated by the New York City Landmarks Prescrvation Commission (LPC), the Murray Hill Historic District and the Sniffen Court Historic District. The Murray Hill Historic District is located from East $35^{\text {th }}$ to East $38^{\text {th }}$ strects, from Park to Lexington avenues. It represents a culturally rich, historic residential neighborhood that contains a varicty of intact row houses built between the 1850's and 1910's. The Sniffen Court Historic District, New York City's smallest historic district consists of ten round-arched stables erected in 1863-64. In addition, the Murray Hill neighborhood also plays host to approximately 25 permanent missions and 13 consulates.

\section{Tudor City}

Tudor City is a self-contained residential neighborhood and a New York City LPC designated historic district, located just south of Turtle Bay and east of Murray Hill. Built in the mid to late 1920's as a middle class residential community by Fred F. French, Tudor City is a residential complex of twelve buildings along Tudor City Place. Bounded by East $44^{\text {th }}$ Street to the north, Sccond Avenue to the west, East $40^{\text {th }}$ Street to the north, and First Avenue to the East, Tudor City offers a Tudor-styled residential housing development that is located in close proximity to Midtown but possesses a screne atmosphere. Although owerwhelmingly residential, there is a hotel along East $41^{\text {"t }}$ Strect, and a number of neighborhood retail shops and scrvices within Tudor City. Tudor City also scrves as the host for 30 permanent missions and 10 consular uses. In total, Tudor City includes 12 buildings, 3,000 apartments, 600 hotel rooms, privatc parks, restaurants, shops, and a post office. All of the Tudor City buildings range in height between 10 to 32 stories and are oriented inwards to the private open spaces of the complex. Currently, all the apartments are cooperatively owned and house approximately 5,000 residents.

\section{Kips Bay}

Similarly to Turtle Bay and the SAC, Kips Bay originated as farmland and the home of a few large country estates. During the turn of the $20^{\text {ll }}$ century, the area also became the home of numerous tenement and boarding houses and two clevated railroad lines along Second and Third avcnues. Not until after the 1960's was the area revitalized and converted into large apartment complexes.

Kips Bay is dominated by large institutional structures and is located just south and cast of Murray Hill along the East River. It is bounded by East $38^{\text {th }}$ Street to the north, the Third Avenuc to the west, East $23^{\text {rll }}$ Strect to the south, and the East River to the east. It includes such notable structures as the New York University Hospital and the Bellevue Medical Center. The New York University Hospital and the Bellerue Medical Center are located along the southern and eastern edge of the Kips Bay from East $26^{\text {th }}$ Street on the south to East $34^{\text {th }}$ Strect on the north, between First Avenue and the FDR Drive. In addition, Kips Bay is also the home of $t$ permanent missions and 3 consular uses.

\section{Rose Hill}

Rose Hill is located just south of Murray Hill and west of Kips Bay, ancl is bounded by East $32^{\text {mil }}$ Street to the north, Madison Avenuc to the west, East $23^{\text {rd }}$ Strect to the south, and Third Avcnue to the cast. Part of CUNY Baruch College and the Stern College for Women are located within Rose Hill. No permanent missions or consular uses are located within Rose Hill. 


\section{Gramercy Park}

Originating as swampland, in the mid-1800's, Samucl B. Ruggels converted the area into a prominent English styled residential development around a private park, Gramercy Park. By the carly 1880's, the area grew to accommodate some of the City's first luxury apartments. During the mid-1900's, however, the Gramercy Park neighborhood become far less fashionable with the extension of the Third Avenue clevated rail line. Most of the remaining $19^{\text {th }}$ century townhouses were converted into apartments. Not until the beginning of the $20^{\text {th }}$ (century did the area become popular with an influx of artists and the development of duplex cooperatives and renovation of row houses. Today, this neighborhood remains as one of Manhattan's highly desirable residential communitics.

Gramercy Park is mainly a private residential neighborhood that is home to a mix of medium-rise residential uses that surround a small private park (Gramerey Park). The park is in the center of the neighborhood and is restricted to the tenants of the surrounding lots. Gramercy Park is a New York City LPC designated historic district and is located just south and west of Kips Bay and directly west of the Peter Copper Village. It is bounded by East $23^{\text {r. }}$ Strect to the north, Park Avenue to the west, East $18^{\text {th }}$ Strect to the south, and Third Arenue to the east. It is also home to CUNY Baruch College. No permanent missions or consular uses are located within Gramercy Park.

\section{Peter Cooper Village}

Planned in 1943, the Peter Cooper Village was constructed by the Metropolitan Life Insurance Company as a component of the Gashouse District. After more than 500 existing building were demolished, construction began on the 21 buildings, ranging in height from 12 to 15 stories, of the current Peter Cooper Village. Since the buildings first opened, the Peter Cooper Village derelopment has remained as one of the City's highly desirable housing complexes because of its close proximity to the business districts of New York City.

The Peter Cooper Village is a small high-density residential development that is located just north of Sturresant Town, east of Gramercy Park, and south of the Veterans Hospital. It is bounded by East $23^{\text {rel }}$ Street to the north, First Ave to the west, East $20^{\text {th }}$ Street to the south, and the FDR Drive to the east. It is composed of 21 apartment buildings, 2,495 apartments, playgrounds, and fifteen additional recreational facilities. In 1990, the Peter Cooper Village housed approximately 5,000 residents.

\section{Stuyvesant Square}

Stuyvesant Square was originally part of Peter Stuyvesant's farm. During the carly $19^{\text {th }}$ century the land was donated to the City to be partially converted into a park. Most of the private houses of Sturvesant Square were built between the 1850's and 1880's. In the late 1900's the area experienced a drastic change when eastern and western European immigrants moved into the newly built brownstones and row houses. Not until the late 1970 's and after the area was designated as a historic district was the arca revitalized.

Stuyesant Square is located within the southwest corner of CB6, just south of Gramercy Park and west of the Stuyresant Town housing development along the East River. It is bound by East $18^{\text {th }}$ Strect to the north, Third Arenue to the " between East $15^{\text {th }}$ and East $17^{\text {th }}$ strects. Although the area is largely a residential community, the Beth Isracl Hospital, the Hospital for Joint Discase-Orthopedic 1nstitute, the Bernstcin Pavilion, and St. Gcorge Memorial Hospital are all located within Stuvesant Square. Stuyresant Square is also recognized as a New York City LPC designated historic district. 


\section{Stuyvesant Town}

Stuyvesant Town was built in 1943 by the Metropolitan Life Insurance Company, after the passage of a state law to encourage slum clearance by private firms. Since the development's inception, Sturvesant Town has remained as a highly desirable residential community with a waiting list of over 8,000 applicants.

Stuyvesant Town is located within the southeastern tip of CB6, just south of the Peter Cooper Village and cast of Stuyvesant Square. It covers approximately 18 City blocks and is bounded by East $18^{\text {th }}$ Strect to the north, First Avenue to the west, East $14^{\text {th }}$ Strect to the south, and Avenue $\mathrm{C}$ to the east. It consists of 35 red-brick buildings of 13 to 14 stories and 8,756 rent-stabilized apartments, tree-lined walkways, and a park. In 1990, the Stuyvesant Town housing project accommodated approximately 7,000 residents.

\section{E. Transportation}

\section{Street Network}

The existing street netw ork of CB6 is typical of most of Manhattan and is a grid system of local cast-west strects with major north-south roadways carrying heavy volumes of traflic. Four avenues, Lexington, Third, and Second, and First avenues, and forty-five cross-town strects comprise the study area. Some of the major crosstown strects located within the study arca are East $59^{\text {th }}$, East $42^{\text {mid }}$, East $34^{\text {th }}$, East $23^{\text {rd }}$, and East $14^{\text {th }}$ strects. A small section of Park and Madison avenues, between East $40^{\text {th }}$ and East $34^{\text {th }}$ Strects, are also included within the study area. East $59^{\text {th }}$ Strect delineates the northern boundary of CB6 and East $14^{\text {th }}$ Strect marks the southern boundary. Lexington Avenuc forms the western boundary, except for an six block area between East $40^{\text {th }}$ and East $34^{\text {th }}$ streets where Madison Avenue forms the western boundary and a three block area between East $22^{\text {nd }}$ and East $19^{\text {th }}$ strects where Park Avenue South forms the western boundary. The Franklin D. Roosevelt Drive (FDR Drive) outlines the castern edge of CB6 and forms the line of demarcation between the interior of the East Side and the East River. The FDR Drive serves as the main artery along the eastern edge of Manhattan from the Battery to the Triborough Bridge. It is a 9.5 -milc, six-lane, limited access highway that largely serves non-commercial traffic.

The entrance to the Queens Midtown Tunnel also lies within CB6. The Quecns Midtown Tunnel is part of Interstate 495, and serves as the westbound terminus of the 71 -mile Long Island Expressway. Situated one mile south of the Quecnsborough Bridge, the Quecns Midtown Tunnel enters into Manhattan in the mid-30's, between East $37^{\text {th }}$ and East $38^{\text {th }}$ strects, within the residential neighborhood of Murray Hill. The Quecns Midtown Tunnel serves to both alleviate traffic congestion on the City's East River Bridges, and provide a direct connection between Long Island City, Quecens and Midtown Manhattan. The Queens portal of the tunnel is in the Hunters Point district of Long Island City.

\section{Public Transportation}

As shown in Table 2-5, CB6 is well served by public transit facilities. CB6 is very accessible to both subway and New York City Transit bus service. The IRT 4/5/6 subway line travels along the western boundary of CB6 and scrves as the main subway line within the study area. The Q/W, E, F, L, 7 and S subway lines also transwerse through CB6 at either East $59^{\text {th }}$, East $51^{\text {" }}$, East $42^{\text {"1I }}$ or East 14 "strects and function as crosstown subway lines to the western side of Manhattan and Brooklyn/Quecens. Grand Central Station is situated just one block west of the CB6 and serves as a major inter-modal transportation hub with connections to commuter rail, subway, bus, and taxis scrvices. In addition, numcrous New York City Transit bus routes directly serve areas within CB6. Ferry service from East $34^{\text {th }}$ Street to Atlantic Highland, New Jersey is also available. 
Table 2-5: Public Transit Facilities within Community Board 6

\begin{tabular}{|c|c|c|}
\hline \multicolumn{3}{|l|}{ Subway Lines } \\
\hline Trains & Subway Line Route & Stations \\
\hline$+/ 5 / 6$ & $\begin{array}{l}\text { ti5- Lexington Express } \\
\text { 6- Lexington Local }\end{array}$ & 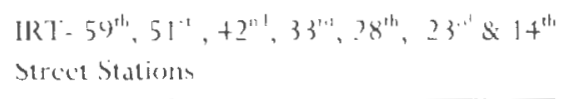 \\
\hline 7 & Flushing twe. Ioral & +2 street Station \\
\hline$Q / W$ & $\begin{array}{l}\text { (2) Continental Are. to Stillwell tre. } \\
\text { W- Ditmars Blud to Stillwell Are. }\end{array}$ & $59^{\text {th }} \& 14^{\text {th }}$ Street Stations \\
\hline$E$ & Eighth Aic. Local & $51 "$ Street Station \\
\hline$F$ & Are of the Americas Local & $51^{-1}$ Stroct station \\
\hline$S$ & shuttle between Times Siquares Grand central & $+2^{\prime \prime}$ Stroet Station \\
\hline$L$ & 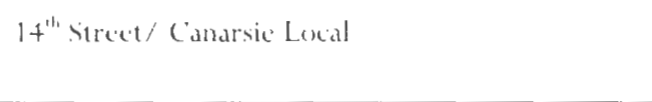 & $\begin{array}{l}14^{\text {th }} \text { Street station and First \& Third tre. } \\
\text { Stations along } 14^{\text {th }} \text { stred. }\end{array}$ \\
\hline \multicolumn{3}{|l|}{ Bus Routes } \\
\hline Bus No. & \multicolumn{2}{|l|}{ Bus Route } \\
\hline 9 & \multicolumn{2}{|l|}{ Awnue B.'Fast Browlwa! } \\
\hline 14 & \multicolumn{2}{|l|}{ 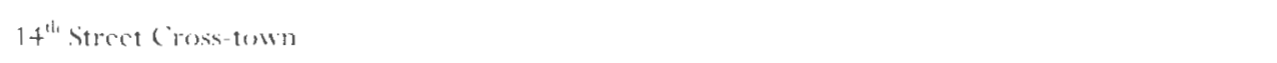 } \\
\hline 15 & \multicolumn{2}{|l|}{ local / Imited Firs/second tienuer } \\
\hline 16 & \multicolumn{2}{|l|}{$3 t^{\text {th }}$ Strend Crosistown } \\
\hline 21 & \multicolumn{2}{|l|}{ Hotsen Street Arenue c } \\
\hline 23 & \multicolumn{2}{|l|}{$23^{1}$ Sitroel Cronstomn } \\
\hline 27 & \multicolumn{2}{|l|}{ 49/50th Sitreets Crosstown } \\
\hline 31 & \multicolumn{2}{|l|}{$57^{\text {th }}$ itrect Sork Arenue } \\
\hline 34 & \multicolumn{2}{|l|}{$34^{\prime \prime}$ street Crosstown } \\
\hline 50 & \multicolumn{2}{|l|}{ 49/50h Street. Crosstown } \\
\hline 98 & \multicolumn{2}{|l|}{ I imited stops, Washingtan Ilegghts Midtrown } \\
\hline 101 & \multicolumn{2}{|l|}{ Third Lexington Amsterlam ticnues } \\
\hline 102 & \multicolumn{2}{|l|}{ Thind/lexingtent/enox trenuen } \\
\hline 103 & \multicolumn{2}{|l|}{ Third I r vinglon Arenues } \\
\hline \multicolumn{3}{|l|}{ Ferries } \\
\hline Ferry Service & \multicolumn{2}{|l|}{ Route } \\
\hline Vhaters & \multicolumn{2}{|l|}{ 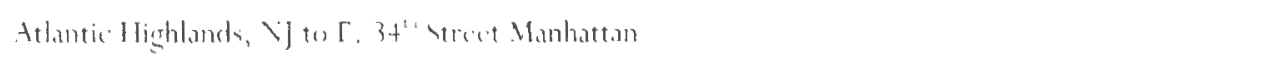 } \\
\hline Siu Strouk & \multicolumn{2}{|l|}{ 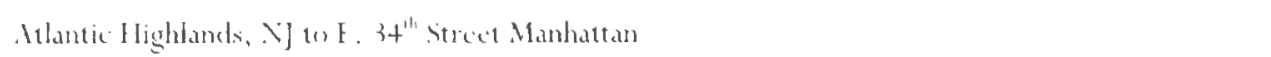 } \\
\hline
\end{tabular}


The Lexington Avenue local and express (4/5/6 lines) subway line is the only subway line that runs the entire length of the cast side of Manhattan from $125^{\text {th }}$ Street to Lower Manhattan. It provides both local and express service between the Bronx and Brooklyn along Lexington and Park avenues in Manhattan, and is the only subway line to serve the entire arca of CB6. The Lexington Avenue local number 6 subway line, serves seven stations within CB6 along Lexington and Park avenues (sce Table 2-5). The Lexington Avenue express number 4 and 5 subway lines only serve three stations, the IRT East $59^{\text {th }}$, East $42^{\text {md }}$, and East $14^{\text {th }}$ Street Stations.

The Q/W subway lines provide service between Brooklyn and Queens via Manhattan. They have replaced the $\mathrm{N} / \mathrm{R}$ subway lines and provide local service in Manhattan between $57^{\text {th }}$ and Canal strects. The $Q$ subway line travels between Continental Avenue, Queens to Stillwell Avenuc, Brooklyn, while the $W$ subway line travels between Ditmars Boulevard, Quecns to Stillwell Avenue, Brooklyn. Both of these subway lines have wo subway entrances within CB6, the East $59^{\text {th }}$ Strect Station and East $14^{\text {th }}$ Strect Station (Union Siquare). Transfer is available between the Lexington local and express trains and the $\mathrm{Q} / \mathrm{W}$ lines at both the East $59^{\text {th }}$ Street Station and Union Square Station. Transfer between the $14^{\text {th }}$ Strect/Canarsie Local, the Lexingten local and express, and the Q/W are available at the Union Square Station. The $14^{\text {th }}$ Street/Canarsic local, the L subway line, provides local subway scrvice between the westside of Manhattan and the eastern edge of Brooklyn, Canarsie, Rockaway Parkway. This subway line has three subway entrances within CB6 along $14^{\text {th }}$ Strect, at the junctions of First and Third arcnues, and at Union Square.

The Sixth Avenue local and the Eighth Arcnue local subway lines also provide service between Brooklyn and Quecns via Manhattan. The Sixth Avenue subway line, F route, provides service between Jamaica, Quecns and Lower Manhattan along Sixth Avenuc in Manhattan to Coney Island in Brooklyn. The Eighth Avenuc subway line, E route, runs on the same tracks as the F route for most of its trip in Quecns and provides service along Quecns Boulevard and the west side of Manhattan. Both of these subway lines serve only one station within

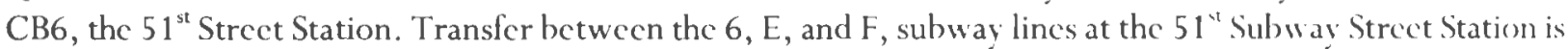
possible.

As the number of people living, working, and traveling in and through the East Sidc of Manhattan has increased dramatically since the 1940's and the East Side's Lexington Avenue subway lines (4, 5, \& 6) are serercly overcrowded and operating at or near capacity during the peak AM and PM hours of the day, there has been renewed interest in the construction of a Second Avenue subway line. During the mid-1940's and 1950's, to further encourage and promote development along the East Side of Manhattan, two former subway lines were removed (the Second Arenuc "El" [1942] and the Thircl Avenue "El" [1956|), leaving the Lexington Avenue subway lines as the only subway serving the East Side population. Since the late 1920's, there has been interest to construct a north-south subway line along Second Arenue. The most recent development proposal, devised in the 1960's, proposed a two-lane track line from Co-Op City in the Bronx to Lower Manhattan. In 1999, the MTA issued the Manhattan East Side Alternative Study Draft Environmental Impact Statement (MESA/DEIS) that identified a short list of alternatives to alleviate the transit congestion on the East Sicle of Manhattan. Comments on the public hearing for the MESA/ DEIS identificd an overw helming preference for a full-length Sccond Avenue subway line. In March 2001, the Sccond Avenue Subway (SAS) Tean began work on a Draft Supplemental Environmental Impact Statement (DSEIS) to eraluate a full-length Second Arenue subway. A summary report was issued in October 2001, and work on the DSEIS is ongoing.

Grand Central Terminal provides rail services to Upstate New York and Connecticut via Metro North commuter rail lines and to New York City subways. Two levels of station platforms and tracks are arailable for Metro-North service, connecting upstate New York and Connecticut with Grand Central Terminal. The Grand Central Subway Station also provides access to the Lexington Arenue 4, 5, and 6 subway routes, the Flushing 
Arenue number 7 line (service between West Midtown to Flushing, Quecns), and the $42^{\text {mil }}$ Strect Shuttle (Sline to Times Square).

Figure 2-9 provides a map of all the local bus routes within CB6. Fourteen New York City Transit Local bus routes operate within the area. North-south bus routes serving the area run along Third, Lexington, First, and Second avenues, whilc east-west routes run along $50^{\text {th }}, 49^{\text {th }}, 42^{\text {thl }}, 34^{\text {th }}, 23^{\text {nd }}$, and $14^{\text {th }}$ strects.

Two private ferry services, NY Fast Ferry and Scastrcak, provide public transit between East $34^{\text {th }}$ Strect Manhattan and Atlantic Highland New Jersey during the weck. Addlitional scasonal ferries also run from East $34^{\text {th }}$ Strect to Shea and Yankee Stadiums during the bascball scason. Seastreak used to run ferries between East $34^{\text {th }}$ Street and the Brooklyn Army Terminal but its service was terminaterl in July, 2001. Prior to March, 2001 NY Waterways operated ferry scrvice between Long Island City and East $34^{\text {th }}$ Street. NY Waterway is intending to reinstate its ferry service from Long Island City once the area is more developed.

\section{LAND USE FORECASTS- A LOOK AHEAD}

As the project area comprises the eastern section of Midtown and there is very minimal vacant commercial space and no current plans for zoning changes in the area, the commercial space demands of local companies and institutions, such as the UN, New York University Hospital, the Bellevue Medical Center, CUNY Baruch College, and the Stern College for Women are extremely limited without major site redevelopment. As noted above, only two percent of CB6's land area is currently vacant space. Since the 1980's, almost all of the commercial, office, or institutional/public facility development or expansion in CB6 has arisen from the conversion of residential or industrial space to commercial, office, or institutional space.

Currently, the study area is experiencing some major development opportunitics (sec Table 2-6). Among them, is the rederclopment of the former Con Edison facilitics, located on four parcels between East $35^{\text {th }}$ and East $41^{\text {th }}$ strects on First Avenue. These prime riverfront propertics occupy 9.2-acres and comprise the largest tract of "undevcloped" land remaining in Midtown. Recently, FMS East River Associates, LLC signed a contract to purchase these four parcels, and is intending to develop a portion of the site into a mixed use facility with a residential and office tower component. The design process for the former Con Edison lacilities is still in its preliminary stages. No detailed development plans or proposals have been established for the site at this time. In order to improve the site, FMS East River Associates, LLC will need to rezone the site, and conduct an environmental revicw of the proposed use. Presently, the Con Edison sites are vacant and unused. A waterside stcam-gencrating plant consisting of two vacant industrial buildings is located on two of the parcels and the other two parcels accommodate parking lot facilitics.

Excluding the future development of the former Con Edison properties, there are only two other major commercial office developments planned for the study area. A 393,000 square foot commercial office building is expected to be developed at 225 East $41^{-1}$ Strect, and a 1.2 million square foot office building is planned at 300 Madison Avenue. Both these commercial developments are expected to be office tower designs, and will add at total of approximately 1.6 million square fect of commercial office space to CB6. The Scient Corporation is expected to be a major tenant of the planned building at 225 East $41^{\text {t }}$ Strect, and the Canadian Imperial Bank of Commeree is expected to be the major tenant of the planned building at 300 Madison Avenue. 


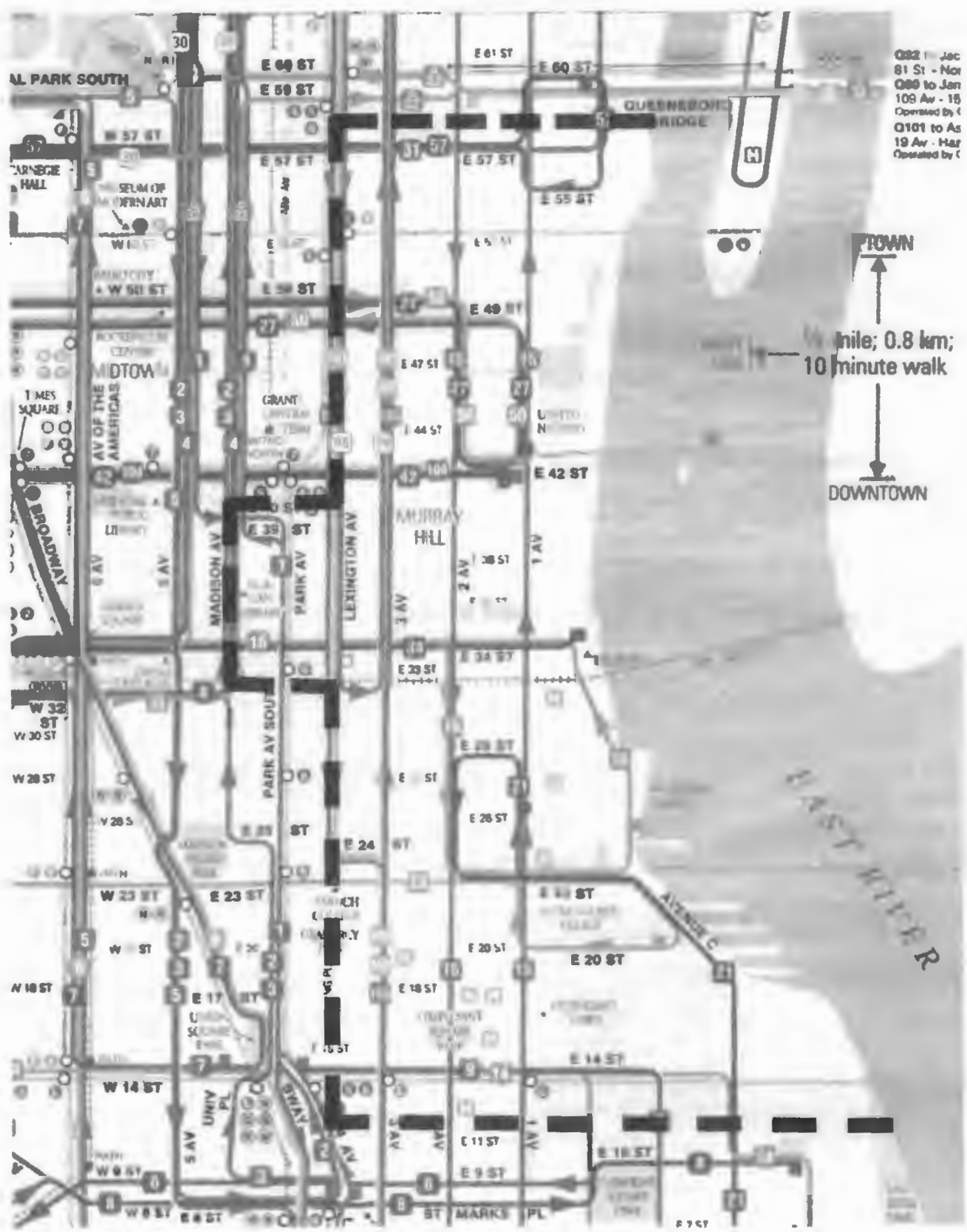

Map Source: New York City Metropolitan Transit Authority 
Other major development projects located in the study area are predominantly residential apartment buildings. Nine high-rise apartment buildings are being developed or renovated within the northern neighborhoods of CB6 and one high-rise apartment building is being developed within the southern section of CB6 in Gramerey Park. These major residential projects include, the newly constructed 860-foot Trump Tower along First Avenue and East $47^{\text {th }}$ Street, the newly developed Montrose at the Midtown Tunnel entrance, the newly restored 19-story Beckman Regent at 931 First Avenuc, the 32-story Grand Beckman at 400 East $51^{\text {" Strect, }}$ the 34-story Chatham apartment building at 181 East $65^{\text {th }}$ Strect, a 22-story apartment building at 52 Park Arcnue, the ExcuStay Suites at 554-6 Thirl Avenue, the Benson Condominium building at 143 East $34^{\text {th }}$ Strect, and another residential apartment building at 301 East $53^{\text {ril }}$ Street.

The southern portion of the project arca is also undertaking a major waterfront redevelopment project for Stuyvesant Cove. A 1.9-acre linear site area along the East River between East $18^{\text {th }}$ and East $24^{\text {th }}$ streets will be redeveloped into a pedestrian esplanade, bikeway, and public park to continue the East River esplanade of Lower Manhattan. Currently, the arca contains a gas station, 515-space parking garage, 36 slip marina, and 428-spaces of surface parking under the FDR Drive, and 297-parking spaces along the water's edge. The proposed waterfront park will bring CB6 one step closer to the creation of a continuous esplanarle along the East River.

The East $54^{\text {th }}$ Strect Recreational Center, the third most heavily used recreational center in the city, is also undergoing reconstruction. For the past 20 years, the East $54^{\text {th }}$ Strect Recreational Center has been experiencing extensive rehabilitation and is expected to have the potential to serve a much greater population when fully restored. In addition, the New York City Economic Development Corporation is spearheading the proposed development of a commercial biotech park, the East River Science Park, in the southern portion of CB6. The proposed project site would be located just north of the Bellevue Medical Center, and south of the New York University Hospital, between First Avenue and the FDR Drive. The proposed biotech park would be compatible with the predominant adjacent uses and revitalize and redevelop a long-underutilized parcel. Views of the East River waterfront would be maintained and the proposed development woulcl provide the opportunity for future waterfront access at East $29^{\text {th }}$ Strect.

Apart from the German mission, consulate, and tourist office building on East $49^{\text {th }}$ Strect and First Avenue, there are no other new large scale UN-related construction projects currently underway. The UN Sccretariat, however, is evaluating options for renovating and upgrading its headquarters campus, and is currently in it:s schematic planning stage. It is anticipated that the UIN Secretariat will require approximatcly 800,000 gsf of office swing space during its proposed renovations to accommodate all of its staff whilc renovations to the campus are underway. In addition, the US mission is planning to esentually rebuild its facility at Fast $45^{\text {th }}$ Strect and First Avcnuc. 


\section{Table 2-6: Recent Development Proposals in Community Board 6}

\section{Proposed Project}

\section{Commercial Development}

Con Edison Industrial Sites

Scicnt Corporation

Canadian Imperial Bank of

Commerce

\section{Residential Developments}

Trump Tower

Montrose

Beckman Regent

Grand Bcekman

The Chatham

52. Park Ave.

301 E. $53^{\text {rdt }}$ St.

Benson Condominiums

ExccuStay Apartments

Post Lumina

\section{Parks \& Recreational Spaces}

Watcrfront Esplanade

F. $54^{\text {th }} \mathrm{St}$. Recreation C $\mathrm{Ctr}$.

\section{Address- Approx. Location}

abutting FDR Dr, between $\mathrm{E}$. $35^{\text {th }} \& 40^{\text {th }} \mathrm{St}$.

$222-225$ E. $41^{\text {" St }}$.

300-310 Madison Ave

845 UN Plaza, along First Ave.

at E. $38^{\text {th }}$ St. \& the Midtown

Tunnel Entrance

931 First Ave.

$400 \mathrm{E} .51^{-4} \mathrm{Sit}$

181 E. $65^{\text {th }}$ St.

52 Park Arc.

301 E. $53^{\text {ral }}$ St.

$143 \mathrm{~F} .34 . \mathrm{st}$

$554-5563^{n d}$ Arr.

$3851^{\prime \prime}$ Ave.

\section{Description}

Office and residential towers

25 -story office building with $393,000 \mathrm{gst}$

35 -story office building with 1.2 million gat

90 -story residential/oftice tower with 376 apartments in Turtle Bas.

20-story building with 97 apartments in Murray Hill.

21 story apartment building in Turtle Bas

32-story building with 89 apartments in Beckman Place

34-story building with 94 apartments in Turtle Bas

22-story building with 17 apartments in Murras Hill.

Residential apartment building in Sutton Place

16-story residential condominium building in Murray Hill

30-storv apartment building in Murray Hill

20-story building with 138 apartments in Grameres Park

1.9-acre pedestrian esplanade, bikewas, and public park development.

Reconstruction of F. 54 St. Recreation (tr.

Source:

Department of City Planning (Spring 2000) Communit, District. Veds for the Fiscal Vear of 20(1) Wunhatan.

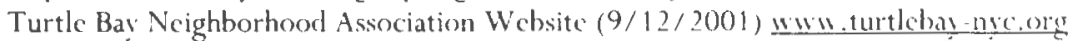

Murray I Iill Neighborhood Association Websitc $(9 / 12 / 2001)$ www. murrahill.orys

The New York City Real Estate Exchange Website (9/28/2000) www. cityrealtr.eom

Municipal Art Society (2001)Wide Open Report.

Studley Report $(9 / 26 / 2001)$ East Hects Hest on the $t^{\text {n.t }}$ Serect Corridor. New York City Studley 2001 Report. www.studelvreport.com/quarterly/2q01/new_iork/submkt_profile.html 


\section{INTRODUCTION}

This section provides a detailed overview of the commercial real estate conditions in the vicinity of the United Nations (UN), including a description of the type of commercial space available, ownership versus rental ratios, price per square foot, and vacancy rates. The purpose of this task is to describe the existing real estate climate in the areas surrounding the United Nations Headquarters and to identify any surplus/deficit of commercial office real estate space in Manhattan Community Board 6 (CB6).

This task also involves examining both the past and present real estate market conditions in Midtown Manhattan and in CB6. A comparison of the current real estate climate in Turtle Bay, Tudor City, Murray Hill and Kips Bay is also provided, to reveal trends in cost, availability, tenure, and type of space available. In addition, this section verifies and updates the commercial properties identified in the Urbitran Associates', United Nations Area Space Availability Study (1998), that could accommodate future commercial office expansion and, in particular, UN-related office space demand.

As the UN and affiliated uses, permanent missions, and consulates have a significant presence in $\mathrm{CB} 6$, this task also describes the pattern of commercial space utilization typical of the international community. This section provides a detailed survey of the existing commercial real estate needs and conditions of the UN Secretariat, the UN's specialized agencies, UN programmes and funds, permanent missions, consulates, and NGO's, including the total office space occupied by each entity, typical turnover rate of office space for a UN-entity, mission or consulate, agencies/missions/ consulates in the market for office space, and tenure trends.

\section{BACKGROUND- COMMERCIAL OFFICE SPACE IN MANHATTAN}

Commercial office space in New York City is generally classified into three categories, and varies according to building type and size, location, and the quality of systems and services rendered. The most prevalent type and highest quality of commercial office space in New York City is classified as Class A. Class A office space is located throughout most of the office markets in Manhattan and represents approximately 60 percent of the total office space inventory in Manhattan. However, the vast majority of Class A office space is concentrated in Midtown. There is approximately 25.0 million square feet of Class A office space in CB6.

Class A office facilities are predominantly located within prime business districts. They are usually contemporary or recently refurbished buildings that project an overall perception of superior quality. Most Class A office buildings were constructed within the last 20 years and possess at least 100,000 sf of floor area. Class A office facilities also have more than 5 -stories and are constructed primarily from steel and concrete with 
high-quality exterior and interior finishes. They are well-maintained and professionally-managed buildings with modern mechanical, electrical, and life safety systems.

Class A office facilities are also the most prestigious office buildings available in New York City. They compete for premier office tenants by offering state-of-the-art systems and services, and providing exceptional accessibility. Average asking rents for Class A office facilities in New York City are generally well aboveaverage, and are some of the highest in the nation. As of May 2002, the average asking rent for Class A office facilities in Manhattan was approximately $\$ 50.00$ per square foot. ${ }^{\prime}$

Class B office space is also located throughout much of New York City and represents a significant portion of the City's office facilities. Approximately 30 percent of the total office space inventory in Manhattan is classified as Class B. Although Class B office space projects an image of high quality and is professionally managed, Class B office space does not compete with Class A office facilities. Class B office buildings are generally smaller and older than Class A buildings. They may have wooden frames and are usually renovated office buildings in good locations. Class B office facilities also show little deterioration or obsolescence. Class B office space competes for a wide range of tenants and offers average rental rates and adequate building systems and services. A verage asking rents for Class B office facilities are generally $\$ 5.00$ to $\$ 10.00$ less per square foot than Class $A$ office facilities in Manhattan and range in price from approximately $\$ 40.00$ to more than $\$ 60.00$ per squarc foot. ${ }^{2}$ The majority of office facilities in CB6 are Class B facilities. Approximately 32 million square feet of office space in CB6 is Class B.

All other commercial office buildings that are not included within either Class A or Class B are classified as Class $\mathrm{C}$ office facilities. Class $\mathrm{C}$ office facilities represent the smallest portion of office space in Manhattan and comprise less than 10 percent of the total office space inventory. Class $\mathrm{C}$ office facilities are predominantly concentrated in the southern portion of Midtown and Downtown, and include industrial loft buildings that have been converted into commercial office space. They offer below-average rental rates and compete for tenants requiring functional yet, affordable office space. Class $\mathrm{C}$ office buildings are generally older commercial buildings and converted lofts that have not been renovated and are in fair condition. Average asking rents for Class C office facilities are generally $\$ 15.00$ to $\$ 25.00$ less per square foot than Class A office facilities in Manhattan and range in price from approximately $\$ 25.00$ to more than $\$ 40.00$ per square foot. ${ }^{3}$ Approximately 10 million square feet of office space in CB6 is Class C.

\section{HISTORIC REVIEW OF MIDTOWN MANHATTAN'S COMMERCIAL OFFICE MARKET}

The international community, including permanent missions and foreign consulates, as well as the UN Headquarters campus and other affiliated uses, are predominantly concentrated in Midtown Manhattan and in CB6. Historic data for Midtown from 1980 and 1990 were evaluated and compared to current commercial office real estate conditions to assess any trends, patterns, or unique occurrences in the last twenty years.

\footnotetext{
1 Colliers ABR (05/2002) Manhottan Office Market Rep ort.

GVA Williams Real Estate Corp. (9/27/2001) Market Research Tools. Www.williamsgva.com

GVA Williams Real Estate Corp. (9/27/2001) Market Research Tools. www, williamsgva.com
} 
In the 1980's, the Manhattan office market was one of the strongest and most balanced rental markets in the country. ${ }^{4}$ Although Manhattan experienced a slower rate of growth in the 1980's than in the 1970's, New York City was still attracting numerous foreign and domestic commercial real estate investors. Many foreign governments and international businesses acquired sizeable commercial properties throughout much of Midtown.

The Midtown office market of the 1980's offered its investors and its tenants both a stable and competitive office real estate market that had one of the lowest office vacancy rates in the United States. 'During the 1980's, Midtown was recognized as one of the strongest and most popular office markets in the nation with an extremely high leasing demand. Its office space availability rate was approximately 2.7 percent in 1980 and 7.2 percent in 1985, less than half the national average of approximately 16 percent (see Table $3-1$ ).

Table 3-1: The Midtown Office Market in the 1980's

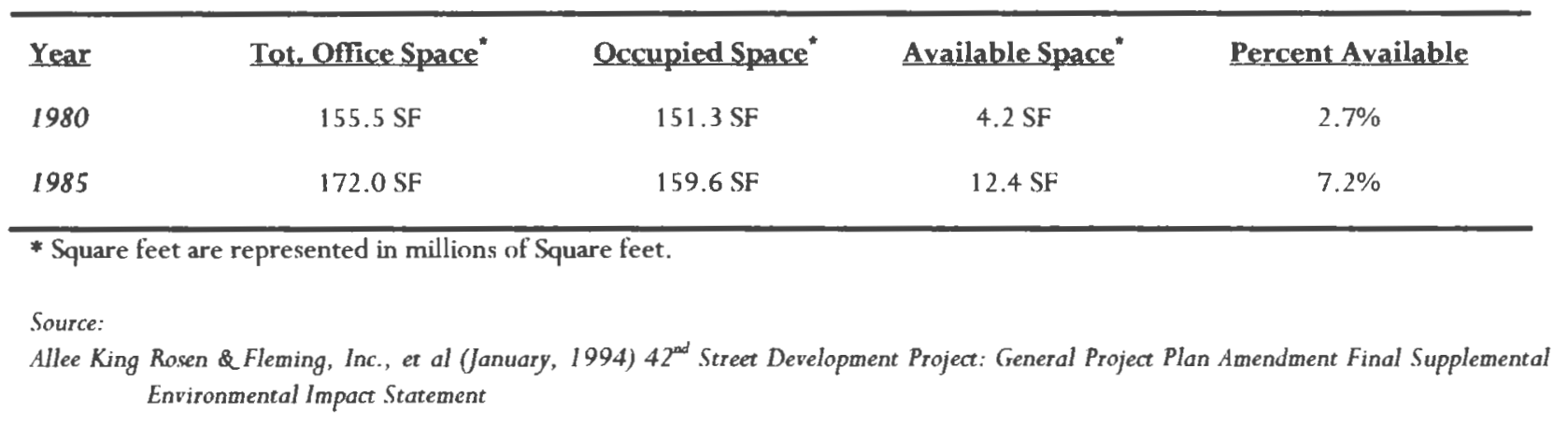

Although the Midtown office market in the first half of the 1980's was extremely tight, with less than 2.7 percent (approximately 4.2 million square feet) of available office space, the latter half of the 1980's brought Manhattan's office tenants lower rental rates and more flexible lease terms. By 1985, approximately 7.2 percent (12.4 million square feet) of office space was available. Class A office space rental rates also dropped significantly in the latter half of the 1980 's to an average of approximately $\$ 35.00$ to $\$ 40.00$ per square foot due to a large influx of available space through new construction. Most of the available commercial office space in Midtown could be leased for less than $\$ 30.00$ per square foot. However, new commercial office space was slightly more expensive, averaging about $\$ 44.00$ per square foot. Large continuous blocks of office space were also in very limited supply and extremely difficult to find. ${ }^{6}$

As the late 1980 's brought substantially less office space construction and relatively low vacancy rates, the Midtown real estate market began to expand both south and west of the commercial core of Midtown. ${ }^{7}$ The

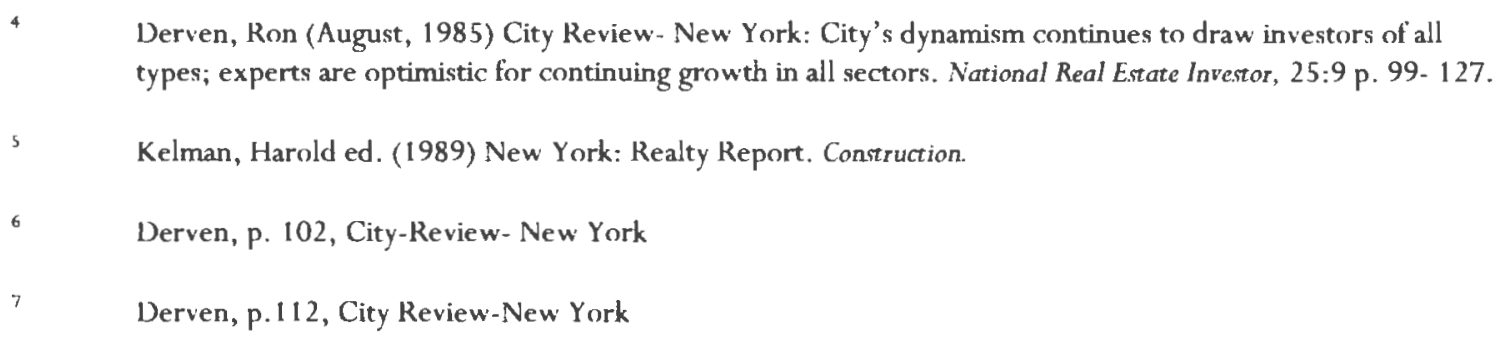


peripheral area of Midtown South became extremely active, as office space south of $34^{\text {th }}$ Street became more desirable. The landmarked and architecturally significant buildings of the southern end of Fifth Avenue between $14^{\text {th }}$ and $23^{\text {rd }}$ Streets were also exceedingly popular as advertising, publishing, and architecture firms quickly absorbed renovated office space. Average asking rents for commercial properties in southern Midtown were significantly cheaper than the majority of office space in Manhattan and ranged from approximately $\$ 14.00$ to $\$ 22.00$ per square foot. ${ }^{8}$ Commercial buyers and tenants also began to have increased interest in prime office space along the West Side of Manhattan, from West $40^{\text {th }}$ Street to West $60^{\text {th }}$ Street between Sixth and Eighth Avenues. Major development initiatives such as the $42^{\text {nd }}$ Street Redevelopment Plan, the West Side Highway Plan, and the Jacob Javits Convention Center served as major catalysts for further development along the West Side. ${ }^{9}$

\section{$42^{\text {nd }}$ Street Redevelopment Plan}

The $42^{\text {nd }}$ Street Redevelopment Plan was a collaborative undertaking between the City of New York and the New York State Urban Development Corporation (UDC) to eliminate blight that characterized West $42^{\text {nd }}$ Street near Times Square during the first half of the $20^{\text {th }}$ century. It was an extensive rehabilitation and redevelopment project that sought to restore the vitality, richness, and productivity of a central and historic part of New York City along West $42^{\text {ad }}$ Street between Broadway and Eighth Avenue. Through creating a 24-hour community and promoting large scale mixed use development, the intent of the $42^{\text {nd }}$ Street Redevelopment Plan was to establish and preserve a healthy, active commercial district at one of New York City's regional and local transportation hubs. The plan redistributed density and bulk regulations under the City's existing zoning regulations and increased floor area from approximately 2.1 million square feet to more than 8.0 million square feet to enable the development of a mix of office uses, a hotel, a wholesale mart, restaurants and other retail uses, as well as the renovation of several historic theaters.

\section{Jacob Javits Convention Center}

The Jacob Javits Convention Center was a large-scale public works project undertaken by a consortium of public and quasi-public agencies including, the Triborough Bridge and Transit Authority (TBTA), the Urban Development Corporation of New York State (UDC), and the Convention Center Operation Corporation (CCOC), during the early 1980's. The overall objective of the project was to expand the City's existing convention center facilities, and develop one of the country's largest, state-of-the-art convention and trading centers. It was also intended to both directly and indirectly raise and generate economic activity in the City, and increase private investment along the City's west side-- long neglected area that largely accommodated parking facilities and warehousing and manufacturing uses related to the garment industry. The City's new convention center would be located on a 22-acre site along the West Side of Manhattan and generally bound by West $39^{\text {th }}$ Street to the north, Twelfth Avenue to the west, West $35^{\text {th }}$ Street to the south, and Eleventh Avenue to the east.

8 Cushman \& Wakefield (1983) City Review: New York: Powerhouse office market. Real Estate Forum 25:9.

9 Derven, p. 112, City-Review- New York 


\section{B. The Midtown Office Market in the 1990's}

During the early 1990's New York City's and Midtown's office market was racked by a myriad of problems. As the nation plunged into a recession and the overall economy began to slow, bankruptcies and substantial job cuts within the financial sector lead to a large accumulation of vacant office space in New York City. Substantial quantities of office space surged into the market. Large-scale office construction in the late 1980's and early 1990 's further increased this accumulation of available space. Sublease space essentially flooded the Midtown office market as companies downsized, and office space availability and vacancy rates soared throughout all of Manhattan. ${ }^{10}$ The Manhattan office market in 1990 had a composite vacancy rate of 13.7 percent (more than 48.2 million square feet of office space was available) and the Midtown office market had an even greater vacancy rate of approximately 16 percent (more than 30.3 million square feet of available space, approximately 63 percent of the total available space in Manhattan was located in Midtown), as shown in Table 3-2.

Table 3-2: The Midtown Office Market in the Early 1990's

\begin{tabular}{lcccc}
\hline Year & Tot. Office Space* & Occupied Space* & Available Space* & Percent Available \\
1990 & $189.0 \mathrm{SF}$ & $158.7 \mathrm{SF}$ & $30.3 \mathrm{SF}$ & $16.0 \%$
\end{tabular}

* Square feet is represented in millions.

Source:

Allee King Rosen \& Fleming, Inc., et al. (January, 1994) 42 $2^{\text {nd }}$ Street Development Project: General Project Plan Amendment Final Supplemental Environmental Impact Statement

Because New York City and Midtown's vacancy rates were high and office space net absorption was extremely negative during the early 1990's, New York City and Midtown, in particular, were viewed as one of the world's least expensive office markets, as compared to the office markets of London, Paris, Tokyo, and Singapore. New York City was also viewed as one of the world's three top financial centers. Rental rates for all types of office space were considered reasonable and landlord concessions were generous. Class A rental rates for prime office space ranged from approximately $\$ 18.00$ to $\$ 78.00$ per square foot, and Class $\mathrm{B} /$ Class $\mathrm{C}$ rental rates for secondary office space ranged from approximately $\$ 10.00$ to $\$ 50.00$ per square foot. Foreign investors continued to invest and acquire commercial properties.

A few areas of Midtown, however, experienced a significant amount of interest and growth throughout the 1990's. The western side of Midtown continued to be one of the most popular commercial office real estate submarkets in New York City and a dominant location for new office construction. Tax abatements and zoning bonus incentives for land parcels along the western side of Midtown made the West Side of Manhattan an extremely appealing location for new development. The immediate area surrounding Grand Central Terminal also experienced a significant amount of interest throughout much of the 1990's. The demand for and the net absorption of commercial office space in the Grand Central submarket was significantly higher than in the $1980^{\prime}$ s. "In addition, the once predominantly commercial retail corridor of Fifth Avenue between East $34^{\text {th }}$ and East $40^{\text {th }}$ Streets began to incorporate a significant commercial office component as vacancy and availability rates for commercial office sharply declined.

\footnotetext{
10 (1992) Society of Industrial and Office Realtors, Landowners, Real Estate Counselors

11 Ciandella, Donald R. (Jun. 1995) National Real Estate Invertor. Atlanta 37:6.
} 
During the latter half of the 1990's, the office markets of Manhattan improved slightly reflecting the overall improved economy. As Manhattan's job market improved modestly, the Midtown office market tightened its supply of quality office space. Most office industries possessed an increased demand for commercial office space and sought Class A office space in Midtown. ${ }^{12}$ Throughout the last four years of the 1990's, availability and vacancy rates for Class $A$ office space declined substantially as rental rates for Class A office space increased steadily. Numerous office users also sought affordable alternatives in the Downtown and southern Midtown office markets as the dot.com space consumption emerged in earnest. ${ }^{13}$ The Manhattan net vacancy rate for Class A office space decreased by more than eight percent from 1993 to 1998 . In 1999, the overall vacancy rate for office space in Manhattan dropped to 6.7 percent, the lowest level in over a decade. ${ }^{14}$

\section{AN OVER VIEW OF EXISTING 2001 COMMERCIAL OFFICE REAL ESTATE CONDITIONS IN NEW YORK CITY}

New York City's office market is one of the most noteworthy and sought-after real estate markets in the United States, if not the world. New York City is also one of the largest and most expansive markets in the country composed of several substantial office markets, including Downtown Brooklyn, Long Island City, and Manhattan.

Primarily a service-oriented economy, New York City's office market is recognized as the corporate and financial capital of the United States. It is also acknowledged as one of the most prominent business centers in the world and home to one of the most diversified economies and a significant international community. ${ }^{15}$ Downtown Brooklyn is recognized as one of the oldest commercial districts in the nation and includes such significant commercial office developments as MetroTech and Renaissance Plaza. Long Island City, Queens is one of the largest commercial employment centers in the Tri-State area and is host to such significant office buildings as the Queens Atrium Building, Citibank Building, and Bridge Plaza Terrace. Manhattan is New York City's largest and most important office market. It is the home of such distinguished office and institutional uses as the New York Stock Exchange, the World Financial Center, the UN Headquarters seat, and several elite universities and hospitals. In addition, Manhattan has also established itself as a leading international capital of publishing, education, fashion, art, and entertainment.

\section{A. The Manhattan Office Market}

Prior to September 11, 2001, Manhattan had one of the most diverse, expansive, expensive, and healthy commercial real estate markets in the nation. ${ }^{16}$ With a total inventory of approximately 350 million square feet of commercial office space, Manhattan has the largest concentration of commercial office space and office-

$\begin{array}{ll}12 & \text { Ciandella, p. 82. } \\ 13 & \text { Corso, Stacey (Feb. 2001) Manhattan Market Scope. Real Estate Forum } \\ & \text { Cushman \& Wakefield (1999) Manhattan Office Markets Strongest in Decade, } \\ & \text { www.propnews.com/market_studies/CW/cw_manhattan_of_11 200.htm } \\ & \text { Derven, p. 99, City Review-New York } \\ & \text { Corso, p. , Manhattan Market Scope. }\end{array}$


related employment in the nation. It is also the home of the largest Central Business District in the nation, if not the world. 13

As office-dependent economic sectors of New York City such as finance, insurance, banking, and real estate are such a significant and substantial part of the City's and Manhattan's economic base, and have been the prime source of job growth in New York City for the last several decades, the status of the office industry is critical to the economic health of New York City. The office industry and the City's overall economy have always been interrelated, each dependent on and contributing to the economic health of the other.

Manhattan's office real estate market is fragile and experiencing a slowdown. Although New York City's office market is relatively stable and stronger than those of most other US cities, Manhattan's office market is experiencing the impact of the collapse of the "dot.com" industry and the flattening of the national economy. Job growth is slowing and the unemployment rate in New York City is rising. ${ }^{18}$ Prior to September 11, 2001, the overall demand for office space was declining throughout most of Manhattan and the office space vacancy and availability rates were increasing. The net absorption rates of commercial office space were also becoming increasingly negative with the failure of dot.com and new media companies. As numerous Manhattan-based companies downsize and/or reconsider future expansion plans, more and more office space has returned to the market and fewer office space transactions have occurred. ${ }^{19}$

Since January 2000 and prior to September 11, 2001, substantial quantities of sublease space flooded New York City's real estate market, increasing Manhattan's commercial office space availability rates from extreme lows in the late 1990's. More than 7 million square feet of sublease space has returned to the market, providing approximately 9.1 million square feet of available commercial office sublease space. As Table 3-3 shows, approximately 8.15 percent ( 28 million square feet) of commercial office space was available in Manhattan prior to September 11, 2001. Since that time, vacancy rates of Class A office space have increased by approximately 3.4 percent to a vacancy rate level of 9.7 percent. $^{20}$

As a result of the destruction of the World Trade Center complex (WTC) and adjacent buildings on September 11,2001 , approximately 14 percent of Manhattan's Downtown commercial office market was destroyed. Although it is too early to assess the total effect of the tragic events on the commercial real estate market of Manhattan, it is estimated that more than 50 million square feet of commercial office space was impacted by the terrorist attacks. Since September 11, approximately 30 percent of displaced companies moved out of Manhattan, taking approximately 62,000 jobs. ${ }^{21}$ Many other displaced companies have found refuge in the unconventional offices of prior new media/internet-related firms in Midtown South, while others opted to relocate to office space in Midtown North. Although a significant amount of displaced Downtown companies have stayed in Manhattan and relocated to the office submarkets of Midtown North and South, the existing supply of available office space still greatly exceeds the current demand. Average vacancy rates throughout all three of Manhattan's main markets continue to escalate, as the current status of the economy forces many companies to continue to downsize and forego expansion plans. In December 2001, average vacancy rates were

17 Insignia ESG (Sept. 2001) Special Report on the Market of New York

18 Eaton, Leslie $(6 / 12 / 02)$ Looking to Suburbs to Map 9/11's Reach. New York Times, Sec. 10, p. 1

19 Kreahling, L. (1/13/2002) Mantattan rents fall, vacancies rise. Crains New York Business.

20 Colliers ABR (05/2002) Manhattan Office Market Report

21 Croghan, L. (1/13/2001) Disappearing Downtown? Crains New York Business. 
approximately 8.8 percent, slightly higher than vacancy rates prior to September 11, 2001 (refer to Appendix A). Since December 2001 , vacancy rates have continued to climb to approximately 10 percent. As vacancy rates have been increasing, a softer rental market has emerged, and average asking rents for commercial office space have dropped be more than $\$ 2.00$ to approximately $\$ 46.00$ per square foot since September $11,2001 .^{22}$

Table 3-3: Inventory of Available Commercial Office Space in Manhattan Prior to 9/11

(Data estimates are from the $2^{\text {nd }}$ Quarter of 2001 \& reflect office inventories prior to September 11, 2001)

\begin{tabular}{|c|c|c|c|c|c|c|}
\hline & \multirow[t]{2}{*}{ Tot. SF" } & \multirow[t]{2}{*}{ Percent of Tot. } & \multicolumn{3}{|c|}{ Available Office Space (SF) } & \multirow{2}{*}{$\begin{array}{c}\text { Percent } \\
\text { Available }\end{array}$} \\
\hline & & & Direct ${ }^{*}$ & Sublet & Tot." & \\
\hline Class A & 207 & $71.6 \%$ & 8.3 & 4.8 & 13.1 & $6.3 \%$ \\
\hline Class B & 108.7 & $24.4 \%$ & 7.8 & 3.7 & 11.5 & $10.6 \%$ \\
\hline Class C & 34.4 & $\underline{4.0 \%}$ & $\underline{3.1}$ & $\underline{0.6}$ & 3.7 & $10.7 \%$ \\
\hline Total & 350.1 & $100 \%$ & 19.2 & 9.1 & 28.3 & $8.1 \%$ \\
\hline
\end{tabular}

Square feet are represented in millions.

Source: GVA Williams Real Estate Corp (9/27/2001) Market Research: Research Tools. www. williamsgra.com

Although commercial office space vacancy rates and availability rates are increasing, large blocks of available office space are still in very short supply. Throughout Manhattan, there are approximately 28 office buildings with 100,000 to 250,000 sf of available space and four office buildings with an excess of $250,000 \mathrm{sf}$ of available space. In addition, Class $\mathrm{A}$ office space is also in very limited supply. ${ }^{23}$

The lack of new office space construction, and Manhattan's diverse tenant base and healthy employment growth within the last four years, however, have kept the commercial real estate markets of Manhattan for the most part steady and balanced. ${ }^{24}$ On average, office space costs are affordable, at approximately $\$ 47.00$ per square foot. ${ }^{2 \bar{j}}$ In addition, most of Manhattan's office space submarkets are secure and office space rents are not dropping significantly. Three of Manhattan's office submarkets (Grand Central, the Financial District, and Gramercy Park) are performing well and are experiencing an influx of office use. The remainder of this section briefly outlines the existing conditions in Manhattan's three major office markets, Midtown North, Midtown South, and Downtown (see Figure 3-1).

\section{The Midtown North Office Market}

The Midtown North office market is located in central Manhattan. It is generally bound by 61 "Street to the North, $38^{\text {th }}$ Street to the South, the East River to the east, and the Hudson River to the west. The submarkets

\footnotetext{
22 Kreahling, L. (1/13/2001) Manhattan rents fall, vacancies rise. Crains New York Business

23 Insignia ESG, Special Report

24 Studely Report (1Q2001) New York City.

25 Kreahling, L. (1/13/2001) Manhattan rents fall, vacancies rise. Crains New York Business.
} 
of Columbus Circle, Grand Central, Plaza, Times Square, and UN Plaza are generally considered to be included in Midtown North (see Figure 3-2).

Midtown North is Manhattan's largest and tightest commercial office market. With a total inventory of approximately 182 million square feet of commercial office space and 8 million square feet of office space currently under construction, ${ }^{26}$ Midtown North comprises approximately 73 percent of Manhattan's commercial office space. Midtown North's office market is also one of Manhattan's most desirable, highest quality, and most expensive office markets (refer to Table 3-4). Almost 72 percent, or 130.9 million square feet, of Midtown North's office space is classified as Class A. Prior to September 11, 2001, the average asking rent of office space in Midtown North was also the most expensive in Manhattan by more than $\$ 20.00$ per square foot.

As shown in Table 3-4, approximately 7.4 percent, of Midtown North's office space was available prior to September 11, 2001. Since September 11, 2001, office space vacancy rates have continued to increase and in December 2001 approximately 7.9 percent of Midtown North's office space was available. Although the majority of office space in Midtown North is Class A, only a small percentage of Class A office space in Midtown North is actually available. Class B and Class $\mathrm{C}$ office space, however, have significantly higher availability rates, as primarily Class $B$ and Class $C$ sublease space have returned to the market within the past two years.

Table 3-4:

Inventory of Available Office Space in the Manhattan Office Markets Prior to 9/11

(Data estimates are from the $2^{\text {nd }}$ Quarter of 2001 \& reflect office inventories prior to September 11, 2001)

\begin{tabular}{|c|c|c|c|c|c|c|c|}
\hline & $\frac{\text { Tot. Office }^{*}}{\text { (SF }}$ & $\frac{\text { Class } A^{*}}{\text { (SF) }}$ & $\frac{\text { Class B* }}{\text { (SF) }}$ & $\frac{\text { Class } C^{*}}{(\text { SF) }}$ & $\frac{\text { Available }}{\text { Space* (SF) }}$ & $\begin{array}{l}\text { Percent } \\
\text { Available }\end{array}$ & $\stackrel{\text { Avg }_{4}}{\text { Asking Rent }}$ \\
\hline Midtown N. & 182.9 & 131.0 & 44.6 & 7.4 & 13.6 & $7.4 \%$ & $\$ 64.42$ \\
\hline Midtown S. & 71.0 & 21.4 & 34.5 & 15.0 & 7.1 & $10.0 \%$ & $\$ 42.43$ \\
\hline Downtown ${ }^{1}$ & 95.4 & $\underline{53.8}$ & 39.6 & $\underline{12.0}$ & 7.7 & $8.1 \%$ & $\$ 41.62$ \\
\hline Total & 349.3 & 206.2 & 108.7 & 34.4 & 28.4 & $8.1 \%$ & $\$ 49.02^{2}$ \\
\hline
\end{tabular}

Square feet are represented in millions.

Downtown estimates are based on an office space inventory prior to the events of September 11, 2001.

Weighted asking average rent.

Source: GVA Williams Real Estate Corp (9/27/2001) Market Research: Research Tools. www. williamsgra.com

Prior to September 11, 2001, the commercial office space vacancy and availability rates were increasing most evidentially in Midtown North, as compared to the rest of Manhattan. The demand for commercial office space in Midtown North was significantly less than the office space demand in Downtown. However, as a result of September 11, more than 27,000 dislocated Downtown employees have relocated to office space facilities in Midtown, absorbing some of the returned sublet space. ${ }^{27}$

\footnotetext{
26 Costar Group (9/26/2001) Market Trends: New York City

27 Croghan, L. (1/13/2001) Disappearing Downtown? Crains New York Business.
} 


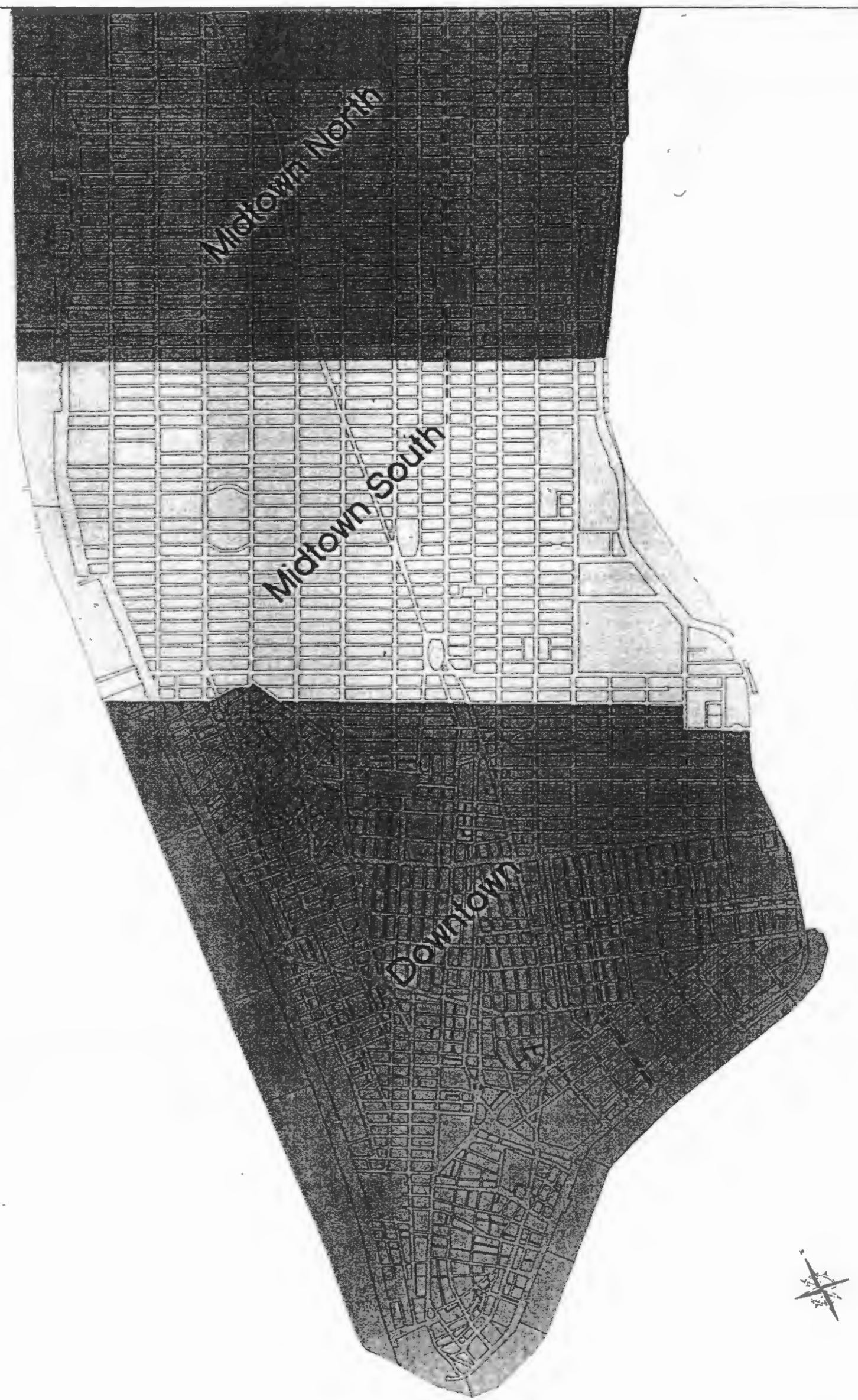




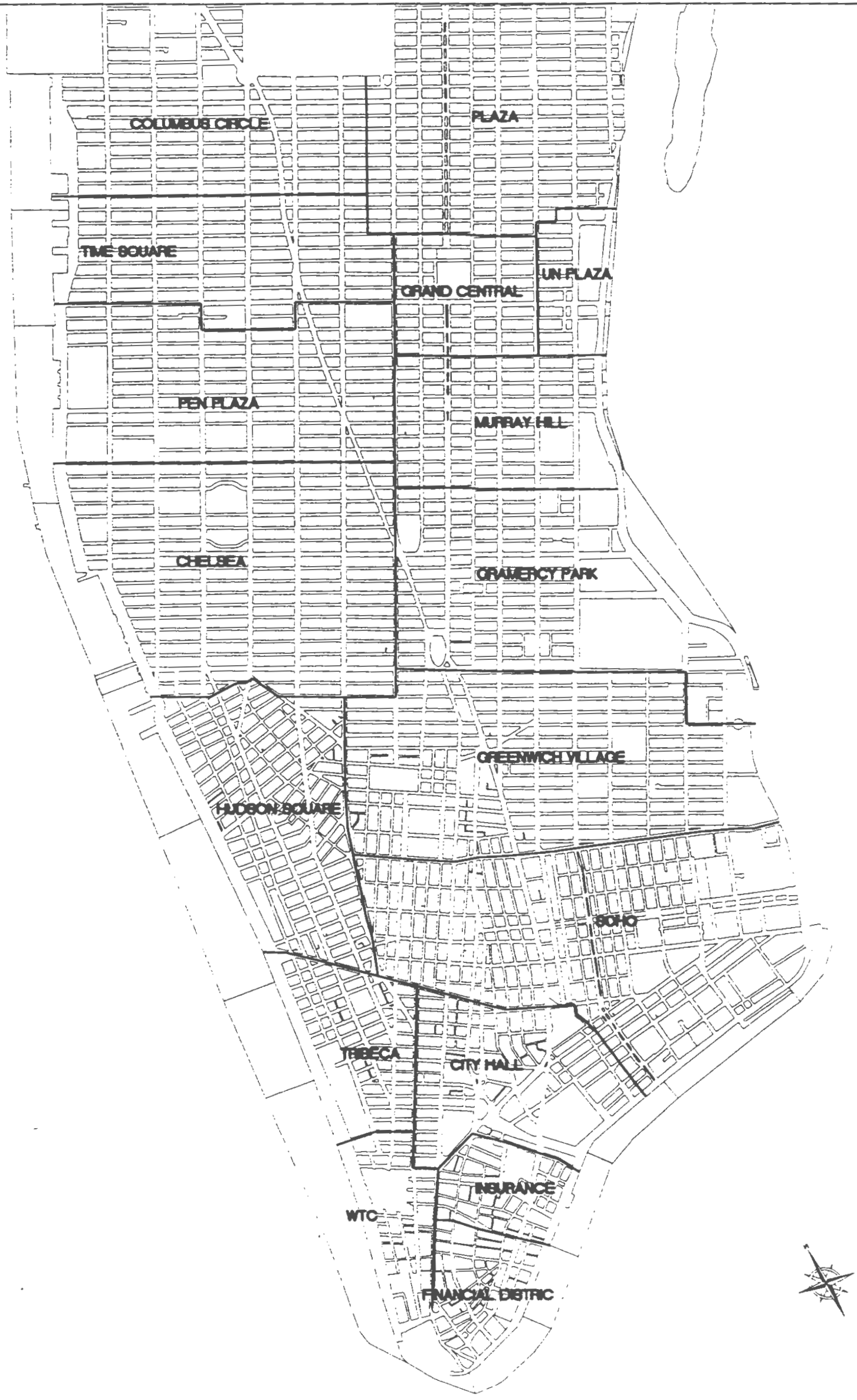


As office space vacancy rates have continued to increase, average asking rents in Midtown North are continuing to drop. Prior to September 11, average asking rents for Midtown North office space had decreased by approximately a dollar within the last two years. Since the events of September 11, average asking rents have dropped to approximately $\$ 58.54$ per square foot. Although Midtown North's average asking rents have dropped, Midtown North remains as Manhattan's most expensive office market.

\section{The Midtown South Office Market}

The Midtown South office market is located just south of the Midtown North office market and just north of the Downtown office market. It is bounded by $38^{\text {th }}$ Street to the north, the East River to the east, the Hudson River to the west, and $12^{\text {th }}$ Street to the South. The submarkets of Chelsea, Murray Hill, Gramercy Park, and Penn Plaza/Garment are generally considered to be included in Midtown South (see Figure 3-2).

Midtown South is Manhattan's smallest commercial office real estate market. With a total inventory of approximately 71 million square feet of commercial office space, Midtown South represents approximately 20 percent of Manhattan's office real estate, and is the home of primarily media, architecture, and publishing firms. ${ }^{28}$ It is also a much newer and less densely packed office market, as compared to either the Downtown or Midtown North office markets. Much of its office facilities are considered to be within an unconventional neighborhood" by many Manhattan firms. ${ }^{29}$ Only within the last 30 years has there been a strong interest in commercial office space in the Midtown South market.

Unlike Manhattan's Midtown North or Downtown office markets, Midtown South is not predominantly comprised of Class A office space. As shown in Table 3-4, the Midtown South office market largely consists of Class B office space. Approximately one-half (34.5 million square feet) of office space in Midtown South is Class B.

Similarly to the Midtown North office market, the Midtown South office market is currently experiencing climbing vacancy rates and a high influx of sublease space. Office space demand is sharply declining and the net absorption of office space in Midtown South is becoming increasingly negative as increasing quantities of office sublease space enter the real estate market. Currently, Midtown South has the highest vacancy rate within all of Manhattan. Prior to September 11, approximately 10 percent of commercial office space in Midtown South was available (refer to Table 3-4). Since September 11, vacancy rates have continued to increase to approximately 11.3 percent, as new media firms downsize and collapse. ${ }^{30}$

As a result of these high vacancy rates and the slowdown of commercial real estate transactions, average asking rental rates for commercial office space are declining significantly in Midtown South. Prior to September 11, the average asking rent for commercial office space in Midtown South was approximately $\$ 41.62$ per square foot (refer to Table 3-4). As of December 2001, the average asking rent for office space in Midtown South was approximately $\$ 40.00$ per square foot, the least expensive price for office space in Manhattan. ${ }^{31}$

\footnotetext{
28 Colliers Abr (1 Q2001) Market Report: New York City. Barometer Report.

29 Kreachling, L. (1/13/2001) Manhattan rents fall, vacancies rise. Croins New York Business

30 Kreahling, L. (1/13/2001) Manhattan rents fall, vacancies rise. Crains New York Business

31 Kreahling, L. (1/13/2001) Manhattan rents fall, vacancies rise. Crains New York Business
} 


\section{The Downtown Office Market}

Manhattan's Downtown office market is located in the southern portion of Manhattan and is generally located south of $12^{\text {th }}$ Street from the East to the Hudson Rivers. It includes the real estate submarkets of City Hall, the World Trade Center, the Financial District, Noho/Soho, Tribeca, and the Insurance district, and is largely dominated by the Financial, Insurance, and Real Estate (FIRE) sector industry. Major banks, brokerages, commodity exchanges, securities firms, government offices, and other financial industries have established their headquarters in Downtown. As of 1998 the FIRE sector industry occupied approximately 10 million square feet of office space in Downtown and in 1999 the securities industry occupied 15.1 million square feet of office space below Canal Street.

Prior to September 11, the Downtown real estate market was one of the strongest markets in the country with vacancies that rivaled Midtown North. ${ }^{32}$ It had a total office space inventory of approximately 95.4 million square feet and an availability rate of 8 percent (see Table 3-4). Similar to both the Midtown North and the Midtown South office markets, the Downtown office market was experiencing higher vacancy rates in recent years. However, unlike the office markets of Midtown South and Midtown North, the Downtown average asking rents held steady and did not drop significantly.

The recent events of September 11, 2001, however, have drastically changed the landscape of Lower Manhattan and the Downtown office market conditions. Over 13.5 million square feet of commercial office space, approximately 4 percent of Manhattan's total office space inventory was destroyed (WTC buildings 1-7) and approximately 1.7 million square feet of office space was severely damaged. ${ }^{33}$ In total, over 50 million square feet of commercial office space in the Downtown office market has eitherbeen destroyed, severely damaged, or impacted.

Currently, Manhattan's Downtown office market is one of the least desirable office markets in the New York City Metropolitan Area. It has a vacancy rate of 8.56 percent and there are more than 15 available office buildings with approximately 100,000 square feet of high-quality space.

Average rental rates are also slowly decreasing. In December 2001, average asking rents were approximately $\$ 41.48$ per square foot, and by May 2002, average asking rents dropped to approximately $\$ 39.47$ per square foot. ${ }^{34}$ Although local, state, and federal governments are offering incentive packages and rental rates are dropping, very few displaced tenants are seeking space in Downtown. In addition, very few Downtown tenants are seeking to renew their leases without 25 to 30 percent rent reductions. Uncertainty, risk, psychological distress, and poor transit options are causing many tenants and employees to relocate to other areas in Manhattan, New Jersey, Long Island, etc. More than 20 percent of displaced companies have moved to New Jersey, and more than 5,300 jobs have moved to other areas outside of New York City. Many companies are also attempting to disseminate some of their holdings in case of future emergencies. However, only a few of these displaced companies have signed long-term leases. ${ }^{35}$

\footnotetext{
32 Kreahling, L. (1/13/2001) Manhattan rents fall, vacancies rise. Crains New York Business.

33 Croghan, L. (1/13/2001) Disappearing Downtown? Crains New York Business.

34. Kreahling, L. (1/13/2001) Manhattan rents fall, vacancies rise. Crains New York Business \& Insignia (05/2002) Northeastern Office Stats

35 Croghan, L. (1/13/2001) Disappearing Downtown? Crains New York Business
} 
The majority of partially damaged and/or impacted buildings surrounding the Word Trade Center (WTC) site will be operational by late Fall 2002. Progress on the cleanup and restoration of the area surrounding the WTC site, however, is extremely difficult and problematic because of the necessary testing for environmental safety and needed structural repairs. ${ }^{36}$ Approximately 16.3 million square feet of office space is expected to reopen and be operational by late 2003 or early $2004 .{ }^{37}$ Seven WTC is expected to be rebuilt by early $2006 .{ }^{38}$

\section{COMMERCIAL OFFICE MARKET CONDITIONS IN COMMUNITY BOARD 6}

As shown in Figure 3-3 and Table 3-5, CB6 is comprised of five office submarkets. The Midtown North submarkets of Plaza, Grand Central, and UN Plaza, and the Midtown South submarkets of Gramercy Park and Murray Hill are all entirely or partially included within CB6. The following describes the current real estate conditions in each of these submarkets. In addition, Appendix B provides a detailed table of the real estate conditions of each commercial office submarket in CB6, as of the second quarter commercial real estate market report of 2001. In total, CB6 has a total office inventory of approximately 58 million square feet (17 percent of Manhattan's total office market). Approximately 8.2 percent (5.5 million square feet) of this office space was available prior to September 11, 2001.

Table 3-5: Real Estate Markets in Community Board 6- 2001 Conditions

(Data estimates are from the $2^{\text {nd }}$ Quarter of 2001 \& reflect office inventories prior to September 11, 2001)

\begin{tabular}{|c|c|c|c|c|}
\hline & Tot. SF of Office & Available SF" & Percent Available & Avg. Asking Rent \\
\hline Midtown North & 182.9 & 13.6 & $7.43 \%$ & $\$ 64.42^{I}$ \\
\hline Plaza & 87.8 & 5.7 & $6.5 \%$ & $s 71.22$ \\
\hline Grand Central & 49.7 & 4.6 & $9.2 \%$ & s60.52 \\
\hline UN Plaza & 1.8 & 0.15 & $8.3 \%$ & 546.46 \\
\hline Midtown South & 71.0 & 7.1 & $10.0 \%$ & $\$ 42.43^{I}$ \\
\hline Murray Hill & 9.3 & 0.86 & $9.2 \%$ & 541.70 \\
\hline Gramercy Park & 19.3 & 1.6 & $8.3 \%$ & $\$ 42.59$ \\
\hline Total $^{2}$ & 167.9 & 12.91 & $7.7 \%$ & $\$ 52.50$ \\
\hline
\end{tabular}

"Square feet is represented in millions.

1 Weighted average asking rent.

2 Total estimate includes all of the real estate submarkets that are included or partially included in CB6.

Source: GVA Williams Real Estate Corp (9/27/2001) Market Research: Research Tools. www. williamsgva.com

36 Croghan, L. (1/13/2001) A slow return for damaged properties. Crains New York Business.

37 Croghan, $\mathrm{L}(1 / 13 / 2001)$ Disappearing Downtown? Crains New York Business.

38 Fredrickson, T. (1/13/2001) Silverstein named builder for $2^{\text {nd }} 7$ WTC. Crains New York Business. 


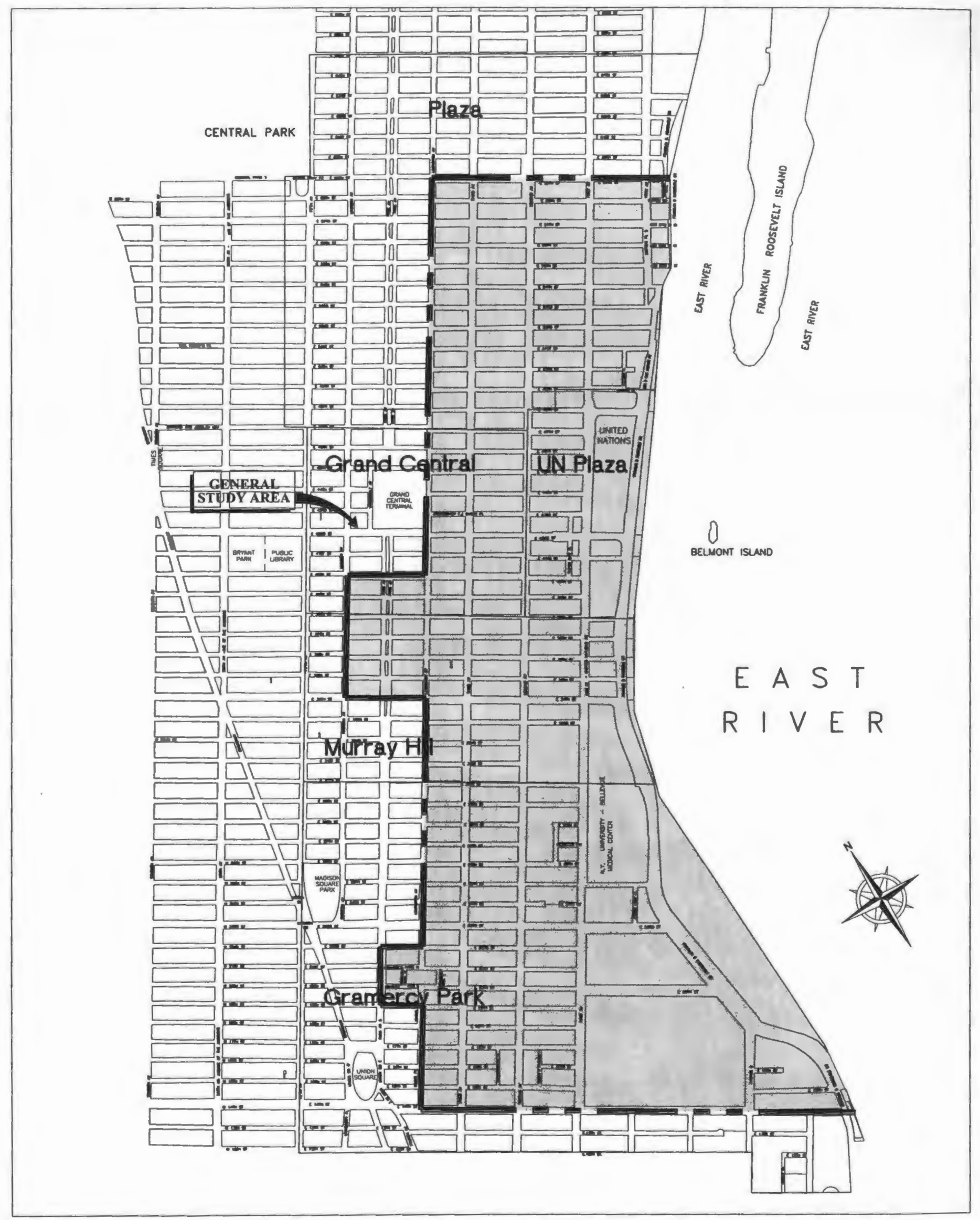




\section{A. The Plaza Submarket}

The Plaza submarket comprises the entire northeastern corner of the Midtown North office market. It is also located within the northern portion of CB6 and largely includes the residential neighborhoods of Turtle Bay, the Sutton Area Community, and Beekman Place, as well as the commercial corridors of Fifth, Madison, Park, Lexington, and Third Avenues. As shown in Figure 3-3, only the southeastern portion of the Plaza submarket, the land to the east of Lexington Avenue and to the south of East $59^{\text {th }}$ Street, is actually included in the CB6 boundaries.

The Plaza submarket is generally bounded by East $65^{\text {th }}$ Street to the north, the East River to the east, East $47^{\text {th }}$ Street to the south, and Fifth Avenue to the west (see Figure 3-2). Included within the Plaza submarket are such significant office buildings as the Citicorp Building on the corner of Lexington Avenue and East $53^{\text {rll }}$ Street, and the General Motors Building and Plaza at 767 Fifth Avenue. In addition, the Plaza submarket also contains a large concentration of permanent missions and consular offices. Approximately 24 permanent missions ( 19 of which are located in CB6 boundaries) and 23 consular offices (15 of which are located in CB6 boundaries) are located in the Plaza submarket. Most of these foreign government offices (more than 85 percent) are located within either Class A or Class B office facilities.

With a total inventory of 87.8 million square feet (see Table 3-5), the Plaza submarket is the largest office submarket of Midtown North, comprising approximately 48 percent of the entire Midtown North office real estate market. Although the Plaza submarket is one of Manhattan's largest office markets (representing 25 percent of the total Manhattan office market), the majority of office buildings and office uses in the Plaza submarket are located outside of CB6 boundaries, between Lexington and Fifth Avenues. The only major pockets of commercial office space that are within CB6 are areas along the commercial corridors of Lexington and Third Avenues. Less than 25 percent (approximately 20 million square feet) of office space in the Plaza submarket is located in CB6.

In addition to being one of the largest office submarkets, the Plaza submarket is also one of the most desirable markets within all of Manhattan. As of September 1, 2001, the Plaza submarket had one of the lowest vacancy rates, with approximately 5.7 million square feet of available office space (see Table 3-6). Approximately 1.4 million square feet of this available space is located in CB6. As office space in the Plaza submarket is highly demanded and often very limited, the average asking rents of the Plaza submarket are also significantly more than the average asking rents of most of Manhattan. Currently, the Plaza submarket is the most expensive office market within CB6. As shown in Table 3-5, the average asking rent for office space in the Plaza submarket is $\$ 71.22$ per square foot, approximately $\$ 7.00$ more than the average asking rent of Midtown North office space.

Table 3-6 provides a further breakdown of the Plaza submarket and shows an inventory of all available office space in the Plaza submarket according to the second quarter report of the office real estate market in 2001. Like most Midtown North office markets, the predominant type of office space in the Plaza submarket is Class A. Approximately 5.9 percent of this Class A office space was available for lease in September 2001. Average asking rents for office space within the Plaza submarket vary according to office type, and range from approximately $\$ 63.00$ to $\$ 72.00$ per square foot. 
Table 3-6: Inventory of Available Office Space in the Plaza Submarket

(Data estimates are from the $2^{\text {nd }}$ Quarter of 2001 \& reflect office inventories prior to September 11, 2001)

\begin{tabular}{|c|c|c|c|c|c|c|c|}
\hline & \multirow{2}{*}{ Tot. SF } & \multirow{2}{*}{$\begin{array}{c}\text { Percent } \\
\text { of Tot. }\end{array}$} & \multicolumn{3}{|c|}{ Available Office Space (SF) } & \multirow{2}{*}{$\begin{array}{c}\text { Percent } \\
\text { Available }\end{array}$} & \multirow{2}{*}{$\begin{array}{c}\text { Avg. } \\
\text { Asking Ren }\end{array}$} \\
\hline & & & Direct & Sublet & Tot. & & \\
\hline Class A & 73.0 & $83.1 \%$ & 2.8 & 1.4 & 4.3 & $5.9 \%$ & s72.86 \\
\hline Class B & 13.9 & $15.9 \%$ & 1.1 & 0.22 & 1.3 & $9.3 \%$ & $\$ 66.19$ \\
\hline Class C & $\underline{0.86}$ & $1.0 \%$ & $\underline{0.05}$ & $\underline{0.007}$ & 0.1 & $7.0 \%$ & $\$ 63.30$ \\
\hline Total & 87.8 & $100 \%$ & 4.0 & 1.6 & 5.7 & $6.5 \%$ & $\$ 71.22^{1}$ \\
\hline
\end{tabular}

Square feet are represented in millions.

Weighted average asking rent.

Source: GVA Williams Real Ertate Corp (9/27/2001) Market Research: Research Tools. www. williamsgra.com

\section{B. The Grand Central/ Midtown East Submarket}

The Grand Central real estate submarket is partially located in the central section of CB6. It includes the commercial corridor of East $42^{\text {nd }}$ Street, the northern section of the residential neighborhood of Murray Hill, and the southern edge of Turtle Bay (see Figure 3-3). Although the Grand Central office market represents one of the larger office submarkets in CB6, it is not entirely included within the community district boundaries. The Grand Central market extends further westward than CB6 and includes the Fifth Avenue commercial corridor.

The Grand Central submarket is bound by East $47^{\text {th }}$ Street to the north, Second Avenue to the east, East $38^{\text {th }}$ Street to the south, and Fifth Avenue to the west (see Figure 3-2). It includes such significant office buildings as Rockefeller Center, the Bear Stearns Building at 245 Park Avenue, and the Chrysler Building at 405 Lexington Avenue. Grand Central Terminal is also located in the Grand Central submarket. In addition to serving as a popular commercial business real estate district dominated by large financial firms and law offices, the Grand Central submarket also contains the second largest concentration of international businesses and institutional offices in the vicinity of the UN Headquarters seat. Currently, 38 permanent missions ( 35 of which are located in CB6 boundaries) and 24 consular offices (18 of which are located in CB6 boundaries) are located in the Grand Central submarket. Approximately 80 percent of these foreign government offices are located in either Class $\mathrm{A}$ or Class B office buildings.

With a total inventory of approximately 49.7 million square feet of office space (see Table 3-5), the Grand Central submarket is not only one of CB6's largest office markets, but also one of Midtown North's largest office submarkets. In total, the Grand Central submarket represents approximately 27 percent of the Midtown North office market and approximately 45 percent of CB6's office market. Unlike the Gramercy Park, Murray Hill and Plaza submarkets, also located in CB6, the Grand Central submarket is densely populated with office buildings that are evenly dispersed throughout its entire area. Approximately 26 million square feet of office space in the Grand Central submarket is located within CB6's boundaries.

The Grand Central submarket has one of the higher office space availability rates in Midtown North, with an availability rate of approximately 9 percent (refer to Table 3-5). Approximately 3.3 million square feet (70 
percent) of this available space is located in CB6. Due to the slightly higher availability rate than the rest of the Midtown North's real estate market, average asking rents of the Grand Central Submarket are also slightly less. As of the second quarter commercial real estate market report of 2001, average asking rents for the Grand Central submarket were $\$ 60.52$ per square foot.

A little more than 55 percent (27.6 million square feet) of office space in the Grand Central submarket is classified as Class A office space (see Table 3-7). Currently, 2.5 million square feet (9 percent) of Class A office space is available for direct or sublet lease, while 1.7 million square feet (approximately 10 percent) of Class $B$ is available and 300,000 square feet ( 7.5 percent) of Class $C$ is available.

Table 3-7: Inventory of Available Office Space in the Grand Central Submarket

(Data estimates are from the $2^{\text {nd }}$ Quarter of 2001 \& reflect office inventories prior to September 11,2001 )

\begin{tabular}{|c|c|c|c|c|c|c|c|}
\hline & \multirow[t]{2}{*}{ Tot. $\mathbf{S F}^{*}$} & \multirow{2}{*}{$\begin{array}{l}\text { Percent } \\
\text { of Tot. }\end{array}$} & \multicolumn{3}{|c|}{ Available Office Space (SF) } & \multirow{2}{*}{$\begin{array}{c}\text { Percent } \\
\text { Available }\end{array}$} & \multirow{2}{*}{$\begin{array}{c}\text { Avg. } \\
\text { Asking Ren }\end{array}$} \\
\hline & & & Direct ${ }^{*}$ & Sublet & Tot." & & \\
\hline Class A & 27.6 & $55.5 \%$ & 1.6 & 0.9 & 2.5 & $9.0 \%$ & $\$ 66.74$ \\
\hline Class B & 17.9 & $36.0 \%$ & 1.2 & 0.53 & 1.7 & $9.5 \%$ & $\$ 53.92$ \\
\hline Class C & $\underline{4.1}$ & $\underline{8.2 \%}$ & $\underline{0.22}$ & $\underline{0.08}$ & $\underline{0.3}$ & $7.3 \%$ & $\$ 47.91$ \\
\hline Total & 49.7 & $100 \%$ & 3.0 & 1.5 & 4.6 & $9.3 \%$ & $\$ 60.52^{1}$ \\
\hline
\end{tabular}

Square feet are represented in millions.

1 Weighted average asking rent.

Source: GVA Williams Real Estate Corp (9/27/2001) Market Research: Research Tools. wWw. william.gra.com

\section{The UN Plaza Submarket}

The UN Plaza real estate market is the only office submarket that is located entirely within the boundaries of CB6 (see Figure 3-3). Generally bound by East $49^{\mathrm{b}}$ Street to the north, the East River to the east, East $38^{\text {th }}$ Street to the south, and Second Avenue to the west, the UN Plaza submarket, includes the residential neighborhoods of Tudor City, Beekman Place, and the northern portion of Kips Bay, as well as the eastern edge of Murray Hill and the southern edge of Turtle Bay. As the UN Plaza submarket is located along the central portion of the eastern edge of CB6, it is largely influenced by the UN Headquarters campus and other affiliated uses.

The UN Plaza submarket includes such major office uses and buildings as 866 UN Plaza, 800 Second Avenue, and 1 Dag Hammerskjold Plaza, as well as the Ford Foundation Building along East $42^{\text {nd }}$ Street. The UN Plaza market is also home to the largest concentration of diplomatic uses within CB6 and within all of New York City. Most of the major office buildings, including the previously mentioned, house several permanent missions, consular offices, and/or NGO's affiliated with the UN. Currently, about one-half (95) of the permanent missions and approximately one-third of $(31)$ the consular offices are located in the UN Plaza submarket. More than 70 percent of these foreign government offices are located in Class A office facilities. 
While UN Plaza is home to the largest concentration of international business offices related to the UN, the UN Plaza office market is Midtown North's smallest commercial office market. With a total office space inventory of approximately 1.8 million square feet (see Table 3-5), the UN Plaza submarket comprises less than 1 percent of the Midtown North office market. The vast majority of buildings located in the UN Plaza submarket boundaries house either residential or institutional uses. In addition, a significant section of UN Plaza is the vacant former industrial facility of Con Edison, located between East $41^{\mathrm{st}}$ and East $35^{\text {th }}$ Streets.

UN Plaza also possesses the smallest amount of available office space within the Midtown North office market and within CB6. Although UN Plaza has a slightly higher availability rate than much of the Midtown North office market, the amount of available space within UN Plaza is equivalent to less than three percent of the available office space within the Plaza submarket. As of September 1, 2001, only 150,000 square feet of commercial office space was available for direct or sublet lease within UN Plaza (see Table 3-8).

Table 3-8: Inventory of Available Office Space in the UN Plaza Submarket

(Data estimates are from the $2^{\text {sd }}$ Quarter of 2001 \& reflect office inventories prior to September 11, 2001)

\begin{tabular}{|c|c|c|c|c|c|c|c|}
\hline & \multirow[t]{2}{*}{ Tot. SF } & \multirow{2}{*}{$\begin{array}{l}\text { Percent } \\
\text { of Tot. }\end{array}$} & \multicolumn{3}{|c|}{ Available Office Space(SF) } & \multirow{2}{*}{$\begin{array}{c}\text { Percent } \\
\text { Available }\end{array}$} & \multirow{2}{*}{$\begin{array}{c}\text { Avg. } \\
\text { Asking Rent }\end{array}$} \\
\hline & & & Direct & Sublet & Tot. & & \\
\hline Class $A$ & 0.75 & $38.9 \%$ & 0.007 & 0.0 & 0.007 & $0.9 \%$ & $s 60.00$ \\
\hline Class B & 1.1 & $60.1 \%$ & 0.079 & 0.064 & 0.14 & $12.7 \%$ & S45.75 \\
\hline Class C & $\underline{0.0}$ & $\underline{0.0 \%}$ & $\underline{0.0}$ & $\underline{0.0}$ & $\underline{0.0}$ & $0.0 \%$ & s0.00 \\
\hline Total & 1.8 & $100 \%$ & 0.09 & 0.06 & 0.15 & $8.2 \%$ & $\$ 46.46^{1}$ \\
\hline
\end{tabular}

Square feet are represented in millions.

1 Weighted average asking rent.

Source: GVA Williams Real Estate Corp (9/27/2001) Market Research: Research Tools. Ww'w.williamsgva.com

Unlike the majority of office submarkets within Midtown North, UN Plaza does not consist of primarily Class A office space. As shown in Table 3-8, the predominant type of office space within the UN Plaza submarket is Class B. Approximately 58 percent (1.1 million square feet) of office space in UN Plaza is Class B. The average asking rent for this available office space in UN Plaza is also significantly less than the majority of office submarkets within Midtown North, and is most comparable to the average asking rent of the Midtown South office submarkets. As shown in Table 3-5, the average cost of renting office space within UN Plaza is $\$ 46.46$ per square foot, approximately $\$ 18.00$ less than the average asking rent of the majority of office space within the Midtown North office market.

As the overwhelming majority of office space in UN Plaza is Class B, the majority of available office space is also Class B. Approximately 13.5 percent (140,000 square feet) of Class B office space is available in UN Plaza.

\section{The Murray Hill Submarket}

The Murray Hill office submarket is located in the central section of $\mathrm{CB} 6$ and includes the commercial corridor of East $34^{\text {th }}$ Street, and the residential neighborhood of Murray Hill, as well as the northern edge of the 
residential neighborhood of Rose Hill (see Figure 3-3). Although the majority of the Murray Hill submarket is included within CB6, the Murray Hill submarket extends further westward than $\mathrm{CB} 6$, and includes the commercial corridor of Fifth Avenue.

The Murray Hill submarket is bound by East $38^{\text {th }}$ Street to the north, the East River to the east, East $30^{\text {bh }}$ Street to the south, and Fifth Avenue to the west (see Figure 3-2), and includes such significant office buildings as the Empire State Building. The Murray Hill submarket also includes New York University Hospital along its eastern boundary. In addition, the Murray Hill submarket is home to a small portion of the international community. Nine permanent missions (eight of which are located in CB6) and three consular offices (all of which are located in CB6) are located in the Murray Hill submarket. Most of these foreign government offices are located in Class $\mathrm{C}$ office facilities.

The Murray Hill submarket represents approximately 13 percent of the Midtown South office market and approximately five percent of CB6's office facilities. With a total inventory of approximately 9.3 million square feet of office space (see Table 3-5), Murray Hill submarket represents one of the smaller office markets within (or partially included within) CB6. Almost all of the office buildings and office space within the Murray Hill submarket are congregated between Fifth and Madison Avenues. There are, however, a few small pockets of office buildings in CB6. A small group of office buildings are located between Madison and Lexington Avenues, and a few other office buildings are located just south of UN Headquarters along First Avenue between East $38^{\text {th }}$ and East $39^{\text {th }}$ Streets. In total, approximately 3.5 million square feet of office space in the Murray Hill submarket is located in CB6.

The Murray Hill submarket possesses one of the higher availability rates of Midtown South. As of September 1, 2001, 8.6 percent of office space was available within the Murray Hill submarket (see Table 3-9). Less than one percent (approximately 210,000 square feet) of this available space in the Murray Hill submarket was located in CB6. The average asking rent for this available space was slightly less than the average asking rents of most office facilities in Midtown South and Midtown North. The average asking rent for office space in Murray Hill was $\$ 41.70$ per square foot, approximately a dollar less than the average asking rent for all of Midtown South.

Table 3-9: Inventory of Available Office Space in the Murray Hill Submarket (Data estimates are from the $2^{\text {nd }}$ Quarter of 2001 \& reflect office inventories prior to September 11, 2001)

\begin{tabular}{|c|c|c|c|c|c|c|c|}
\hline & \multirow[t]{2}{*}{ Tot. SF } & \multirow{2}{*}{$\begin{array}{c}\text { Percent of } \\
\text { Tot. }\end{array}$} & \multicolumn{3}{|c|}{ Available Office Space (SF) } & \multirow{2}{*}{$\begin{array}{c}\text { Percent } \\
\text { Available }\end{array}$} & \multirow{2}{*}{$\begin{array}{c}\text { Avg. } \\
\text { Asking Rent }\end{array}$} \\
\hline & & & Direct & Sublet" & Tot." & & \\
\hline Class $A$ & 1.8 & $19.8 \%$ & 0.07 & 0.13 & 0.20 & $11.1 \%$ & $\$ 44.71$ \\
\hline Class B & 5.5 & $58.8 \%$ & 0.26 & 0.29 & 0.55 & $10.1 \%$ & S41.18 \\
\hline Class C & $\underline{2.0}$ & $21.3 \%$ & $\underline{0.08}$ & $\underline{0.02}$ & $\underline{0.10}$ & $5.2 \%$ & 538.47 \\
\hline Total & 9.3 & $100 \%$ & 0.4 & 0.4 & 0.8 & $9.2 \%$ & $\$ 41.70^{\prime}$ \\
\hline
\end{tabular}

Source: GVA Williams Real Ertate Corp (9/27/2001) Market Research: Research Tools. www. williamsgra.com 


\section{E. The Gramercy Park Submarket}

The Gramercy Park submarket is located within the southern portion of CB6 and includes the residential neighborhoods of Peter Cooper Village, Stuyvesant Town, Stuyvesant Square, and Gramercy Park (see Figure 33). The southern portions of Rose Hill and Kips Bay are also partially included within the Gramercy Park submarket. Similarly to the Murray Hill submarket, the Gramercy Park submarket also extends beyond the boundaries of CB6.

As shown in Figure 3-2, the Gramercy Park submarket is generally bound by East $30^{\text {th }}$ Street to the north, the East River to the east, East $12^{\text {th }}$ Street to the south, and Fifth Avenue to the west, and includes the Con Edison facilities between East $14^{\text {th }}$ and East $10^{\text {th }}$ Streets along the East River. Notable office buildings included within the Gramercy Park submarket include the New York Life Building at 51 Madison Avenue, Metlife Plaza at One Madison Avenue, and the Con Edison Building at Four Irving Place. In addition, the Gramercy Park submarket also includes the Bellevue Medical Center, the Veterans Administration Medical Center, and the Beth Israel Medical Center. The Gramercy Park submarket also contains one permanent mission and one consular use (only the permanent mission is located in CB6), which are both housed within Class B office facilities.

Similarly to the Murray Hill submarket, the Gramercy Park submarket is located in a predominantly residential area. With a total inventory of approximately 19.3 million square feet of office space (see Table 3-5), the Gramercy Park office market is twice as large as the Murray Hill submarket and represents approximately 27 percent of the Midtown South office market. Almost all of this office space, however, is located outside of CB6 and is concentrated between the commercial corridors of Fifth and Madison Avenues, and in the vicinity of Union Square. Only a few office buildings are scattered throughout the eastern section of the Gramercy Park submarket and within CB6. In total, approximately 6.5 million square feet of office space in the Gramercy Park submarket is located in CB6.

The Gramercy Park submarket also has relatively low vacancy and availability rates that are comparable to the rates of the Midtown North submarkets. Approximately 8 percent of Gramercy Park's office space was available prior tp September 1, 2001, and approximately 560,000 square feet of this available space was located in CB6. The average asking rent for this available space in Gramercy Park is also slightly higher than the average rent of most of Midtown South. The average cost for office space in Gramercy Park is approximately $\$ 42.59$ per square foot (refer to Table 3-10).

As shown in Table 3-10, Gramercy Park submarket has a relatively even mix of Class A, Class B, and Class C office space. Approximately 6.6 million square feet of office space in Gramercy Park is Class A, approximately 7.6 million square feet is Class $B$, and approximately 5.0 million square feet is Class $C$. The vast majority of available space in the Gramercy Park submarket, however, is Class B. Approximately 11 percent $(840,000$ square feet) of Class $B$ office space is available for $\$ 44.00$ per square foot. 
Table 3-10: Inventory of Available Office Space in the Gramercy Park Submarket

(Data estimates are from the Second Quarter of 2001 \& reflect office inventories prior to September 11, 2001)

\begin{tabular}{|c|c|c|c|c|c|c|c|}
\hline & \multirow[t]{2}{*}{ Tot. SF } & \multirow{2}{*}{$\begin{array}{l}\text { Percent } \\
\text { of Tot. }\end{array}$} & \multicolumn{3}{|c|}{ Available Office Space (SF)" } & \multirow{2}{*}{$\begin{array}{c}\text { Percent } \\
\text { Available }\end{array}$} & \multirow{2}{*}{$\begin{array}{c}\text { Avg. } \\
\text { Asking Rent }\end{array}$} \\
\hline & & & Direct & Sublet & Tot. & & \\
\hline Class A & 6.6 & $34.4 \%$ & 0.25 & 0.03 & 0.28 & $4.2 \%$ & $\$ 43.60$ \\
\hline Class B & 7.6 & $39.6 \%$ & 0.55 & 0.29 & 0.84 & $11.1 \%$ & $\$ 44.04$ \\
\hline Class C & $\underline{5.0}$ & $26.0 \%$ & 0.33 & $\underline{0.09}$ & $\underline{0.43}$ & $8.6 \%$ & s39.08 \\
\hline Total & 19.2 & $100 \%$ & 1.1 & 0.4 & 1.5 & $8.15 \%$ & $\$ 42.59^{\prime}$ \\
\hline
\end{tabular}

"Square feet are represented in millions.

Weighted a verage asking rent.

Source: GWA Williams Real Estate Corp (9/27/2001) Market Research: Research Tools. www. williamsgva.com

\section{PATTERN OF COMMERCIAL OFFICE SPACE UTILIZATION TYPICAL OF THE INTERNATIONAL COMMUNITY IN NEW YORK CITY}

Since its inception in the mid-1940's, the UN has greatly expanded its membership, budget, and efforts. To meet these increasing functions, the UN presence in New York City has gone through periods of expansion, and the UN Secretariat has also increased its staff levels. However, the UN has also equally experienced periods of reduction in its office space needs and in its staff levels. During the past several years, the UN has been in its reduction/stability mode and has been reducing its demand for commercially leased office space in New York City. In addition, the UN Secretariat has also reduced its staff levels over the past few years.

The UN System has been able to minimize its demand for commercially (privately) leased office space in New York City through the assistance of the United Nations Development Corporation (UNDC). Established in the late 1960's, UNDC was created to help meet the increasing needs of the UN community (the UN System, UN specialized agencies, programmes, and funds, and permanent missions) for more office space, hotel accommodations, appropriate housing, and other essential facilities in close proximity to the UN Headquarters campus. Through surveying the present and future needs of the UN community, UNDC formulates and implements development plan(s) for the United Nations Development District (see Tasks 1 \& 2) to meet the existing and future office space, housing, and other facility needs of the UN community.

Although the UN has improved and refurbished its headquarters campus in New York City, the UN campus is no longer sufficient or capable of housing all of the UN Secretariat's staff, the UN's specialized agencies, and UN programmes and funds. During the last two decades, in particular, most of UN's specialized agencies, UN programmes and funds, and some of the UN Secretariat's staff have been forced to relocate and occupy significant quantities of office space outside of the UN Headquarters in nearby commercial and/or UNDC office buildings.

The UN's membership has also greatly expanded over the years and many member states have leased, bought, or developed commercial office space in New York City to accommodate permanent mission space. Since 1945, 140 nations have become member states of the UN (East Timor and Switzerland became members in Fall 
of 2002), bringing the total membership to 191 states, 188 of which have established permanent mission offices in the New York Metropolitan Area. Ninety-eight percent (187) of these permanent missions are located in Manhattan, near the UN Headquarters campus.

As the UN Community has grown and expanded its efforts, what the UN refers to as a "Civil Society" (nongovernmental organizations [NGO's] or grassroots connections) has also diversified and expanded. Over the past 50 years, thousands of NGO's, non-profit and voluntary citizens' actions groups, have become part of the UN's Civil Society (affiliated with the UN Department of Public Information), and hundreds of these NGO's have elected to establish headquarters or regional offices in New York City, near the UN Headquarters campus.

In addition to serving as the UN Headquarters, New York City is also considered a world city and a significant part of the global economy. Throughout the last twenty years, 117 member states have established foreign consular offices in New York City. Currently, there are 100 foreign consulates located in New York City, 99 of which are located in Manhattan. The other 16 consular offices closed their respective consular offices during the 1980 's and early 1990's.

The following sections provide an in-depth discussion of the existing commercial office space needs of the UN Secretariat, the UN's specialized agencies, UN programmes and funds, permanent missions, consular uses, and NGO's. In addition, Appendix C provides a complete survey of the UN System's existing office space, as of August 2001.

\section{A. The United Nations, Specialized Agencies, and Programmes \& Funds}

As discussed in Task 1, the UN System is an interwoven network of organizations and entities that perform a range of duties to improve and shape global relations. It primarily consists of six major organs, including the General Assembly, Security Council, and Secretariat (international, administrative staff of the UN), as well as a variety of programmes and funds, and specialized agencies. Although the UN maintains a significant presence throughout the world, its main administrative headquarters are located in New York City. The UN Secretariat, the UN Office for Project Services (UNOPS), the UN Development Program (UNDP), and several funds, including the UN International Children's Emergency Fund (UNICEF) and the UN Populations Fund (UNFPA), all have their worldwide headquarters and administrative offices in Manhattan CB6.

\section{The United Nations (UN Secretariat)}

Throughout the last 35 years, the UN has experienced a constant shortage of adequate office space, conference rooms, and meeting facilities. As the UN Headquarters campus was originally designed to accommodate approximately 70 member states and currently there are 191 member states, the UN Secretariat building is severely over-utilized.

Over the last 50 years, several physical alterations and expansions to the headquarters campus have been necessary. During the late 1970's and early 1980's, the conference rooms of the headquarter's buildings were substantially reconfigured to accommodate additional seating for new member states. In addition, the headquarters campus has been also improved with the construction of three buildings (the Dag Hammarskjold Library [a gift of the Ford Foundation], the South Annex building, and the North Lawn Extension). Table 3-11 shows the existing buildings' gross floor area and useable floor area on the UN Headquarters campus, as of August 2001.

In total, the UN Headquarters campus is approximately 18 -acres and is occupied by approximately 1.3 million square feet of useable floor area. However, only the Secretariat building (approximately 653,000 gsf) currently serves as a major office facility and accommodates most of the administrative staff (Secretariat) of the UN. All 
other buildings on the headquarters campus have another primary function and accommodate only incidental office space. The South Annex building serves as the campus's cafeteria. The General Assembly and the Conference buildings largely contain meeting and conference facilities, while the North Lawn building mainly serves as a printing plant. The UNITAR building, which was purchased by the UN in 1993, is not located on the UN Headquarters campus. It is located immediately across the street from the Secretariat Building on the northwest corner of First Avenue and East $45^{\text {th }}$ Street. The UNITAR building serves as the UN's pass and identification office. and also houses some incidental office space.

Table 3-11: Existing Buildings on the UN Headquarters Campus

\begin{tabular}{|c|c|c|c|}
\hline Name of Building & Gross Floor Area (SF) & Useable Floor Area (SF) & Description \\
\hline Conference Bldg. & 442,390 & 409,000 & $5 \mathrm{Fl} ., 2$ basements \\
\hline General Assembly Bldg. & 316,557 & 70,779 & $5 \mathrm{Fl}, 1$ basement \\
\hline Secretariat Bldg. & 900,000 & 653,000 & $35 \mathrm{Fl}, 3$ basements \\
\hline Library & 118,600 & 93,640 & $3 \mathrm{Fl}, 3$ basements \\
\hline North Lawn Bldg. & 99,500 & 84,300 & $0 \mathrm{FL}, 2$ basements \\
\hline South Annex & 39,300 & 30,075 & $2 \mathrm{Fl}, 0$ basements \\
\hline UNITAR BIdg.' & 22,620 & $\underline{N} / \mathrm{A}$ & $5 \mathrm{Fl}, 1$ basement \\
\hline Total & $1,938,967$ & $1,340,794$ & \\
\hline
\end{tabular}

Source: UN Facilities Management Office, 2001

In addition to refurbishing and improving the UN Headquarters campus, the UN System has also been forced to seek and lease additional office space outside of the UN Headquarters campus to accommodate some of the UN Secretariat's staff, and almost all of the UN's specialized agencies, and UN programmes and funds. These efforts have primarily been accomplished through the development of the United Nations Development District and the creation of the UNDC.

As private enterprise had been ineffective in providing a sufficient supply of affordable office and other essential facilities, the New York State legislature created a state public benefit corporation, UNDC, to assist the UN System and its permanent missions, and the City of New York in meeting the UN community's office space needs, hotel accommodations, appropriate housing, and other needed facilities. UNDC was established to formulate and implement development strategies or plans for the coordinated future development of the United Nations Development District. It is intended to serve as a real estate technical advisor and broker for the UN community, as well as a liaison between the UN System and permanent missions, and federal, state, and/or local authorities. UNDC has the ability to acquire and dispose of real property, and construct, purchase, and/or rehabilitate office buildings within the United Nations Development District to secure suitable facilities for the UN community. Because of UNDC efforts, the UN System's commercial office space demand/occupancy is minimal. 
UNDC office facilities are not part of the Manhattan commercial office market. They are reserved for UNrelated uses, and are not available (leased) to private companies or any other commercial entities. UNDC acquires, purchases, or constructs office buildings to accommodate the UN Secretariat, the UN's specialized agencies, UN programmes and funds, and permanent missions.

Since the late 1960's, UNDC has developed approximately 1.8 million square feet of office space in the vicinity of the UN to serve the UN System and permanent missions. Some of UNDC's more significant office buildings include One, Two, and Three UN Plaza. All three of these buildings are primarily occupied by the UN's specialized agencies, UN programmes or funds, and by several permanent missions to the UN.

One and Two UN Plaza are 39- and 40-story buildings that are Class A, glass tower office buildings along the north side of East $44^{\text {th }}$ Street between First and Second Avenues. They accommodate approximately $700,000 \mathrm{sf}$ of office space and a 427-room hotel. UNDP, the UN Secretariat, and several foreign missions are housed within One and Two UN Plaza. Three UN Plaza is located directly across the street from One and Two UN Plaza, and is the current headquarters of UNICEF. It also accommodates residential apartments housing UN staff and foreign diplomats, among other residents.

As of August 2001, the entire UN System leased approximately 1.4 million square feet of Manhattan office space for an average asking rent of approximately $\$ 26.00$ per square foot (See Table 3-12). Almost half of this leased space is occupied by the UN Secretariat, while the remainder of office facilities serve the UN's specialized agencies and UN programmes and funds. Although the UN System leases slightly more than the total useable floor area of the UN Headquarters campus, more than 58 percent (approximately 819,000 sf) of this leased office space is owned by UNDC. Less than 42 percent (approximately 582,000 sf) of the UN System's leased office space is privately owned (commercially leased by the UN System), of which approximately 112,000 is leased by the UN, and the remainder by various UN programmes and funds and specialized agencies. Approximately 79 percent $(476,000 \mathrm{sf})$ of the UN Secretariat's leased office facilities are owned by UNDC, and approximately 43 percent (343,000 sf) of the UN's specialized agencies, and programmes and funds' office facilities are owned by UNDC.

Table 3-12: Office Space Leased by the UN System in Midtown

\begin{tabular}{lcccc}
\hline Organization & UNDC SF Leased & Commercial SF Leased & Tot. SF Leased & Avg. Rent \\
UN & 476,000 & 110,000 & 596,000 & $\$ 24.00$ \\
UNDP & 163,000 & 200,000 & 363,000 & $\$ 22.00$ \\
UNICEF & 180,000 & 95,000 & 275,000 & $\$ 27.00$ \\
UNOPS & 0 & 76,000 & 76,000 & $\$ 43.00$ \\
UNFPA & 0 & $\underline{91,000}$ & $\underline{91,000}$ & $\mathbf{\$ 3 6 . 0 0}$ \\
Total & $\mathbf{8 1 9 , 0 0 0}$ & $\mathbf{5 8 2 , 0 0 0}$ & $\mathbf{1 , 4 0 1 , 0 0 0}$ & $\mathbf{\$ 2 6 . 0 0}$ \\
\hline
\end{tabular}

Source: UN Facilities Management, August 2001 


\section{Programmes \& Funds}

The United Nations Development Program (UNDP), United Nations International Children's Emergency Fund (UNICEF), and United Nations Population Fund (UNFPA) are all headquartered outside of the UN Headquarters campus, within several high-quality, office buildings along the eastern side of Midtown, in CB6.

As shown in Table 3-13, UNICEF occupies approximately 275,000 gsf of Class A office space in CB6. The majority (approximately 65 percent) of this office space ( 3 UN Plaza) is owned by UNDC. Less than 35 percent (approximately 95,000 gsf) of UNICEF's office space is commercially leased. Its main worldwide headquarters are located at 3 UN Plaza in the UN Plaza submarket, and its other office facilities are located at 633 Third Avenue in the Grand Central submarket.

UNDP currently leases significant portions of three office buildings in the UN Plaza submarket and occupies a total of approximately $363,646 \mathrm{sf}$ of office space. Approximately 45 percent of this office space is owned by UNDC and less than 200,000 sf is commercially leased by UNDP. Its main worldwide headquarters are at 304 East $45^{\text {lh }}$ Street.

The United Nations Population Fund's (UNFPA) headquarters are located in the Grand Central submarket at 405 Lexington Avenue. It occupies approximately 91,000 sf of Class A office space. All of UNFPA's office facilities are commercially leased.

Table 3-13: Administrative Offices of UN Programmes \& Funds in Midtown

\begin{tabular}{|c|c|c|c|c|}
\hline Bldg. Address & Tot. SF Occupied & Cost per SF & $\frac{\text { Lease Expiration }}{\text { Date }}$ & Description of Building \\
\hline \multicolumn{5}{|l|}{ UNICEF } \\
\hline 3 UN Plaza & 180,491 & $\$ 32.50$ & $2026^{*}$ & $\begin{array}{l}\text { Class A mixed use building, } 15 \text {-stories, } \\
\text { owned by UNDC }\end{array}$ \\
\hline 633 Third Ave & $\underline{94.769}$ & s27.00 & Not Available & Class A commercial condos, 38-stories \\
\hline Total & 275,260 & & & \\
\hline \multicolumn{5}{|l|}{$U N D P$} \\
\hline I UN Plaza & 162,838 & s22.00 & $2008^{*}$ & Class A, 39-stories, owned by UNDC \\
\hline 304 E. $45^{\text {th }} \mathrm{St}$ & 179,473 & s22.00 & $2005^{*}$ & Class A, 17-stories, City-owned \\
\hline 336 E. $45^{\text {th }} \mathrm{St}$ & $\underline{20,335}$ & s22.00 & $2005^{*}$ & Class B, 15-stories, Uganda Mission \\
\hline Total & 362,646 & & & \\
\hline \multicolumn{5}{|l|}{ UNFPA } \\
\hline 220 E. 42 St & $\underline{91,000}$ & $\$ 43.00$ & Not Available & Class A, occupies $4^{\text {th }}$ Fl., Chrysler Bldg. \\
\hline Total & 91,000 & & & \\
\hline
\end{tabular}

\footnotetext{
Represents the year the existing lease terminates. Tenant does have the option to renew once current lease expires.

Source: UNICEF, UNDP, \& UNFPA, August 2001
} 


\section{B. Permanent Missions}

As noted previously, there are currently 187 member states maintaining permanent missions at UN headquarters in New York City. Only the UN member states of Equatorial Guinea, Kiribati, Palau, and East Timor, which joined the organization in 1968, 1999, 1994, and 2002 respectively, do not have permanent representation (missions) in New York City. The UN member state of Equatorial Guinea, however, maintains a permanent mission outside of Manhattan, in Mount Vernon, New York. Almost all other UN member states maintaining permanent missions at UN Headquarters are located in Midtown within three Manhattan Community Board Districts (as shown in Table 3-14).

Although permanent missions possess the flexibility to locate anywhere within the City, the vast majority of permanent missions located in Manhattan are concentrated near or adjacent to the UN Headquarters campus along the eastern side of Midtown in CB6. Approximately 83 percent (1.61 million square feet) of permanent missions are located in CB6, while less than 17 percent (400,000 sf) of permanent missions are located outside of CB6. Most of the permanent missions located in CB6 are located in Class A office facilities (approximately 73 percent), while less than 30 percent are located Class B facilities.

Table 3-14: Permanent Missions Referenced by Manhattan Community Board

\begin{tabular}{ccccc}
\hline Community Board & Tot. No. of Permanent Missions & Tot. Percentage & Tot. SF Occupied \\
CB6 & 155 & $83 \%$ & 1.61 Million \\
CB5 & 9 & $5 \%$ & 100,000 \\
CB8 & $\underline{23}$ & $\underline{12 \%}$ & $\underline{300,000}$ \\
Total & 187 & $100 \%$ & $\mathbf{2 . 0 1}$ Million \\
\hline
\end{tabular}

Estimate of Total Square Feet of commercial office space occupied by the 186 missions is extrapolated from data collected on 166 permanent missions in New York City.

Table 3-15 provides a more detailed look at the 155 permanent missions located in CB6. As shown in Table 315, approximately 56 percent (87) of the permanent missions located in CB6 are situated within the northern portion of CB6, in the Turtle Bay community. Slightly less than 20 percent (30) are located in the residential neighborhood of Tudor City and approximately 16 percent (25) are located in Murray Hill.

In total, permanent missions occupy approximately 2.01 million square feet of office space in Manhattan, representing less than 1 percent of the Manhattan office real estate market. The average size of a typical mission is approximately $10,800 \mathrm{sf}$. However, permanent missions in NYC range in size from less than 1,000 sf to more than 200,000 sf of office space. Currently, 37 percent (68) of UN member states own their permanent mission offices, while approximately two-thirds (119) of UN member states lease commercial office space (112) or UNDC office space (7) for their permanent missions. Average asking rents for permanent mission office space range from approximately $\$ 25.00$ to $\$ 73.00$ per square foot. 
Table 3-15: Permanent Missions in Community Board 6- Referenced by Neighborhood

\begin{tabular}{lccc}
\hline Neighborhood & Tot. No. of Permanent Missions & Tot. Percentage & Tot, SF Occupied \\
Turtle Bay & 87 & $56 \%$ & 880,000 \\
Sutton Place & 1 & $<1 \%$ & 10,000 \\
Murray Hill & 25 & $16 \%$ & 280,000 \\
Kips Bay & 4 & $3 \%$ & 50,000 \\
Tudor City & 30 & $19 \%$ & 280,000 \\
Beckman & $\underline{8}$ & $\underline{5 \%}$ & $\underline{110,000}$ \\
Total & $\mathbf{1 5 5}$ & $\mathbf{1 0 0 \%}$ & $\mathbf{1 . 6 1 \text { million }}$ \\
\hline
\end{tabular}

Estimate of Total Square Feet of commercial office space occupied by the 186 missions is extrapolated from data collected on 166 permanent missions in New York City.

As noted above, permanent missions have the freedom to locate anywhere within the City. They are not restricted by any City, State, or Federal regulations to locate within certain specified areas. Although most permanent missions prefer to locate within close proximity to the UN Headquarters campus, a few missions are located along the Upper East Side and in central Midtown. The actual location of permanent missions is largely market driven and determined by the individual operating budgets of particular missions. Permanent missions lease or purchase office space where they can afford it, and behave like any other private commercial business or institution. In addition, the turnover rate of leased permanent mission space is not cyclic or predictable. There is no pattern that identifies the duration of a typical commercial lease for a permanent mission, each permanent mission is a separate entity and operates independently.

Approximately 966,000 sf of mission space in Manhattan is owned by a foreign government and more than 1.0 million square feet of permanent mission office space is leased by a foreign government. The average size of a leased permanent mission is $9,000 \mathrm{sf}$, while the average size of a permanent mission owned by a foreign government is $14,000 \mathrm{sf}$. Unlike the UN System's leased office facilities, the majority of permanent mission leased office space is privately owned. Less than 3 percent (approximately 63,000 gsf) of permanent mission office space is owned by UNDC.

Most permanent missions occupy commercial office space in the Midtown North office submarkets of UN Plaza (51 percent), Plaza (13 percent) and Grand Central (20 percent) (see Table 3-16). Less than 6 percent of permanent missions are located in the Midtown South office submarkets of Gramercy Park and Murray Hill. The majority of (approximately 51.6\%) permanent missions also occupy Class A office facilities. However, a quarter of all permanent missions are located in unclassified commercial condominiums, brownstones, or residential buildings. 
Table 3-16: Permanent Missions Referenced by Manhattan Office Markets

\begin{tabular}{lccc}
\hline Office Submarket & Tot. No. of Permanent Missions & Tot. Percentage & Tot. SF Occupied \\
\cline { 2 - 3 } UN Plaza & 95 & $51 \%$ & 930,000 \\
Plaza & 24 & $13 \%$ & 310,000 \\
Grand Central & 38 & $20 \%$ & 390,000 \\
Upper East Side & 20 & $11 \%$ & 260,000 \\
Murray Hill & 9 & $5 \%$ & 110,000 \\
Gramercy Park & 1 & $\leq 1 \%$ & 10,000 \\
Total & $\mathbf{1 8 7}$ & $\mathbf{1 0 0 \%}$ & $\mathbf{2 . 0 1}$ million \\
\hline
\end{tabular}

Estimate of Total Square Feet of commercial office space occupied by the 186 missions is extrapolated from data collected on 166 permanent missions in New York City.

More than half of permanent missions have relocated at least once within the last twenty years. Only 28 percent of permanent missions have remained within the same office facilities since 1988. At least twenty permanent missions could be in the market for new commercial office space in the next five years and at least nine could be seeking office space in the next two years.

In addition to the 187 current member states maintaining permanent missions in New York City, there is also one permanent non-member state, Holy See, and sixteen other entities or intergovernmental organizations including, Palestine, the Asian-African Legal Consultative Committee, European Community, and the League of Arab States, maintaining permanent observer mission offices at UN Headquarters in New York City. Like most permanent missions, the vast majority of these observer missions are concentrated along the eastern side of Midtown in CB6, near the UN Headquarters campus (see Table 3-17). Only the Caribbean Community (an observer mission) is located outside of Manhattan, in Rego Park, Queens.

Table 3-17: Permanent Observer Missions Referenced by Manhattan Community Board

\begin{tabular}{lc}
\hline Community Board & Tot. Percentage \\
$C B 5$ & $6 \%$ \\
$C B 6$ & $76 \%$ \\
$C B 7$ & $6 \%$ \\
$C B 8$ & $12 \%$ \\
Total & $100 \%$ \\
\hline
\end{tabular}

Almost all observer missions lease their commercial office space in the office submarkets of UN Plaza, Grand Central, Plaza and Gramercy Park, and the residential areas of Murray Hill, Turtle Bay, Tudor City and Sutton Place. Only the Organization of African Unity owns its permanent observer mission, and only two observer entities lease office space from UNDC in One UN Plaza. Several observer missions are located in the same 
office buildings as many permanent missions and other international/UN-related organizations. Commercial offices that contain at least one observer mission include, 800 Second Avenue, 801 Second Avenue, 747 Third Avenue, 630 Third Avenue, and 633 Third Avenue. Average asking rents for many observer missions range from approximately $\$ 45.00$ to $\$ 60.00$ per square foot. As the majority of observer missions do not own office facilities, observer missions are relatively small and occupy less than an average of 10,000 sf.

\section{Foreign Consulates}

There are currently 100 foreign consular offices located in New York City, 99 of which are located in Manhattan. Only San Marino's foreign consulate is located outside of Manhattan in Elmont, Queens. Although the majority of consular uses, like permanent missions, are located within the boundaries of CB6, several consulates, occupying more than 460,000 sf of commercial office space, are located within four other Manhattan Community Boards, as shown in Table 3-18.

As consular uses are not directly affiliated with the UN, consular offices are more dispersed throughout the City and are generally located further away from UN Headquarters than the majority of permanent missions. Although 63 percent of foreign consulates (690,000 sf) are located in CB6, the remaining 37 percent $(460,000$ sf) are scattered throughout central Manhattan, the Upper East Side, Downtown, and the western side of Manhattan.

\section{Table 3-18: Foreign Consulates Referenced by Manhattan Community Board}

\begin{tabular}{lccc}
\hline Community Board & Tot. No. of Consulates & Tot. Percentage & Tot. SF of Office Occupied $^{2}$ \\
\cline { 2 - 3 } CB6 & 63 & $63 \%$ & 690,000 \\
$C B 5$ & 19 & $19 \%$ & 210,000 \\
CB8 & 13 & $13 \%$ & 200,000 \\
CB1 & 2 & $2 \%$ & 20,000 \\
CB4 & $\underline{2}$ & $\underline{2 \%}$ & $\underline{30,0000}$ \\
Total & 99 & $100 \%$ & $\mathbf{1 . 1 5}$ Million \\
\hline
\end{tabular}

Estimate of Total Square Feet of commercial office space occupied by the 99 foreign consulates is extrapolated from data collected on 86 foreign consulates in New York City.

The majority of the 62 foreign consular offices located in CB6 are generally concentrated within the southeastern portion of Turtle Bay (see Table 3-19). Approximately 21 percent of foreign consulates are located in Murray Hill along the commercial corridors of Second, Third, and Lexington Avenues, and 16 percent are located within the four block area of Tudor City. 
Table 3-19: Foreign Consulates in Community Board 6- Referenced by Neighborhood

\begin{tabular}{lccc}
\hline Neighborhood & Tot.No. of Consulates & Tot. Percentage & Tot. SF of Office Occupied \\
Turtle Bay & 35 & $55 \%$ & 370,000 \\
Sutton Place & 1 & $1 \%$ & 10,000 \\
Murray Hill & 13 & $21 \%$ & 160,000 \\
Kips Bay & 3 & $5 \%$ & 30,000 \\
Tudor City & 10 & $16 \%$ & 100,000 \\
Beekman Place & 1 & $1 \%$ & $\underline{20,000}$ \\
Total & 63 & $\mathbf{1 0 0 \%}$ & $\mathbf{6 9 0 , 0 0 0}$
\end{tabular}

Estimate of Total Square Feet of commercial office space occupied by the 99 foreign consulates is extrapolated from data collected on 86 foreign consulates in New York City.

In total, foreign consulates are estimated to occupy approximately 1.15 million square feet of commercial office space in Manhattan, less than one percent of Manhattan's total office space inventory. They are slightly larger than permanent mission offices and have an average office size of approximately 11,600 sf. Currently, 37 percent of foreign consulates have direct ownership of their commercial office facilities and 62 percent lease commercial office space. Average asking rents for consular uses are slightly more than permanent mission space and range from approximately $\$ 33.00$ to $\$ 90.00$ per square foot.

Like permanent missions, consular uses possess the flexibility to locate anywhere within the City, and are under no restrictions to locate within certain specified areas. Many consular uses are located in the same office building or within the same general area as their respective county's permanent mission to the UN in CB6, but others are located in Downtown or along the west side of Manhattan. Consular office locations are determined by market trends and the individual operation budgets of foreign governments. Consular office facilities are leased or purchased where foreign countries can afford the space.

The majority of consular space is commercially leased by foreign governments. The average size of a consulate owned by a foreign government is approximately $16,000 \mathrm{sf}$, and the average size of a leased consulate is approximately 9,000 sf. Approximately 592,000 sf of consular office space is currently owned by a foreign government, while approximately 992,000 sf of consular office space is commercially leased.

Similarly to the majority of permanent missions, most consular uses are located in the Midtown North office submarkets of UN Plaza, Plaza, and Grand Central (see Table 3-20). Consular uses predominantly occupy Class A office facilities. Approximately 625,000 sf of consular office space is Class A. Less than 200,000 sf of consular office space is Class B, and less than 93,000 sf is Class C. 
Table 3-20: Foreign Consulates Referenced By Manhattan Office Markets

\begin{tabular}{lccc}
\hline Submarket/Market & Tot. No, of Consulates & Tot. Percentage & Total SF Occupied \\
UN Plaza & 30 & $30 \%$ & 320,000 \\
Plaza & 27 & $27 \%$ & 270,000 \\
Grand Central & 23 & $23 \%$ & 270,000 \\
UPper East Side & 9 & $9 \%$ & 150,000 \\
Downtown & 3 & $3 \%$ & 20,000 \\
Midtown North & 3 & $3 \%$ & 60,000 \\
Murray Hill & 3 & $3 \%$ & 50,000 \\
Gramercy Park & 1 & $1 \%$ & 10,000 \\
Total & 99 & $100 \%$ & $\mathbf{1 . 1 5}$ Million \\
\hline $\begin{array}{l}\text { Estimate of Total Square Feet of commercial office space occupied by the } 99 \text { foreign consulates is extrapolated from data } \\
\text { collected on } 86 \text { foreign consulates in New York City. }\end{array}$
\end{tabular}

Since 1980 , approximately 50 percent of existing foreign consulates have relocated to new office facilities. Only a quarter of the existing foreign consulates have remained within the same office space throughout the last twenty years. Nine of the existing consulates could be in the market for new office facilities within the next five years, and two consular offices could be seeking new offices within the next year.

\section{Civil Society- Non-Governmental Organizations (NGO's)}

As described in Task 1, the UN's Civil Society is very large, extremely diverse, and wide-reaching. Currently, there are over 1,500 non-governmental organizations (NGO's) affiliated with the UN Department of Public Information that perform a variety of services and humanitarian efforts. As NGO's are non-profit, voluntary citizen's groups that serve as grassroots advocates for the UN and its programmes, they have very different administrative needs, operations, and budgets. NGO's office space needs and conditions are as diverse as their individual goals, venues, and mandates. They range in size and budget from very small (with no administrative offices and minimal staff) to very large (entire office buildings and hundreds of employees).

Currently, the UN Headquarters campus does not have any official office space or central meeting facilities reserved for NGO's. As affordable office space is severely limited in Manhattan, NGO headquarter and regional offices in New York are scattered mostly throughout the five boroughs, Westchester County, and New Jersey. Although slightly more than 200 NGO's have some type of administrative space in Manhattan near the UN Headquarters campus, many of these NGO's operate on a part-time schedule or out of residential homes. Very few NGO's operate full-time out of classified office facilities (i.e., Class A, Class B, or Class C office space). Several NGO's that have similar interests and/or programs occupy office space within the same building and/or share the same office facilities to reduce costs and expenses. Most NGO's that do operate out of classified, commercial office facilities in Manhattan are located within the same buildings. Very few NGO's (less than 17\%) own office facilities, while the vast majority (more than $83 \%$ ) lease their needed administrative space.

Approximately 55 NGO's have headquarter facilities within the immediate vicinity of the UN, in CB6 within the office submarkets of UN Plaza (57\%), Grand Central (30\%), Plaza (9\%) and Murray Hill (4\%). Most of these 
NGO's are stationed along Second Avenue and along the cross-town streets directly west of UN Headquarters campus in Turtle Bay, Tudor City, and Murray Hill. They occupy affordable office space facilities within the same buildings as many permanent missions and/or consular uses. Significant office buildings containing NGO's include: 777 UN Plaza, 211 East $43^{\text {rl }}$ Street, 801 Second Avenue, 633 Third Avenue, 823 UN Plaza, and 866 UN Plaza. Average asking rents for NGO's range from less than $\$ 30.00$ per square foot to more than $\$ 60.00$ per square foot.

One of the more significant and larger NGO's located in CB6 is the Ford Foundation at 320 East $43^{\text {rl }}$ Street. This organization is one of the few NGO's that owns its office space facilities, and occupies a substantial amount of space. In total, the Ford Foundation occupies approximately 340,000 gross sf of office space.

\section{SNAPSHOT OF COMMERCIAL SPACE AVAILABILITY}

This section of the report provides a snapshot of the commercial space availability in the vicinity of the United Nations Headquarters. The purpose of this assessment is to identify potential development sites for the construction of new offices facilities and existing commercial office buildings that could accommodate some of the UN's and other related uses' future commercial office expansion. In addition, this section also updates the results of Urbitran Associates' 1998 commercial space availability assessment of a small area of eastern Manhattan. The specific study area limits for the 1998 study were defined as Lexington Avenue to the west, the FDR Drive to the east, East $34^{\text {th }}$ Street to the south, and East $49^{\text {th }}$ Street to the north (see Figure 3-4). This study area largely includes the predominantly residential neighborhoods of Turtle Bay, Kips Bay, Tudor City, Murray Hill and the UN Headquarters campus, as well as portions of the commercial office submarkets of UN Plaza, Grand Central, and Murray Hill. Most of the UN System's current office facilities, as well as the majority of permanent missions and several consular uses are also located within this defined area.

Desirable sites for office space expansion or development are typically defined as vacant properties, underdeveloped or underutilized sites, and developed sites with large amounts of available space. As the study area is in close proximity to central Midtown and the space demands of local companies, universities, and major institutions, such as the UN and surrounding hospitals, are significant, opportunities for commercial office space expansion are often limited without major site redevelopment. Although many sites within the study area seem ripe for redevelopment, many sites within this area of eastern Manhattan do not represent viable opportunities for office space development. During the last twenty years, many of the property owners/developers within this study area sold or transferred some or all of their development rights to other surrounding lots. As a result, many of the existing sites with low density development cannot be further developed. However, there are several opportunities for office space expansion, as several office buildings within the area currently have available space. As of September 1, 2001, approximately 5.5 million square feet of office space was available in CB6. The following provides an updated, detailed survey of current vacant/underutilized property and existing commercial buildings that could potentially accommodate future commercial office development or expansion in the area immediately surrounding the UN.

\section{A. Potential Sites for New Construction}

As mentioned previously, the immediate area surrounding the UN Headquarters campus is located adjacent to Midtown, and is one of the most densely developed urban neighborhoods in the country. Although office and commercial activity in Midtown is predominantly concentrated along Third Avenue and the blocks to the west and some crosstown streets, such as East $42^{\text {nd }}$ Street, several significant commercial and institutional uses are 


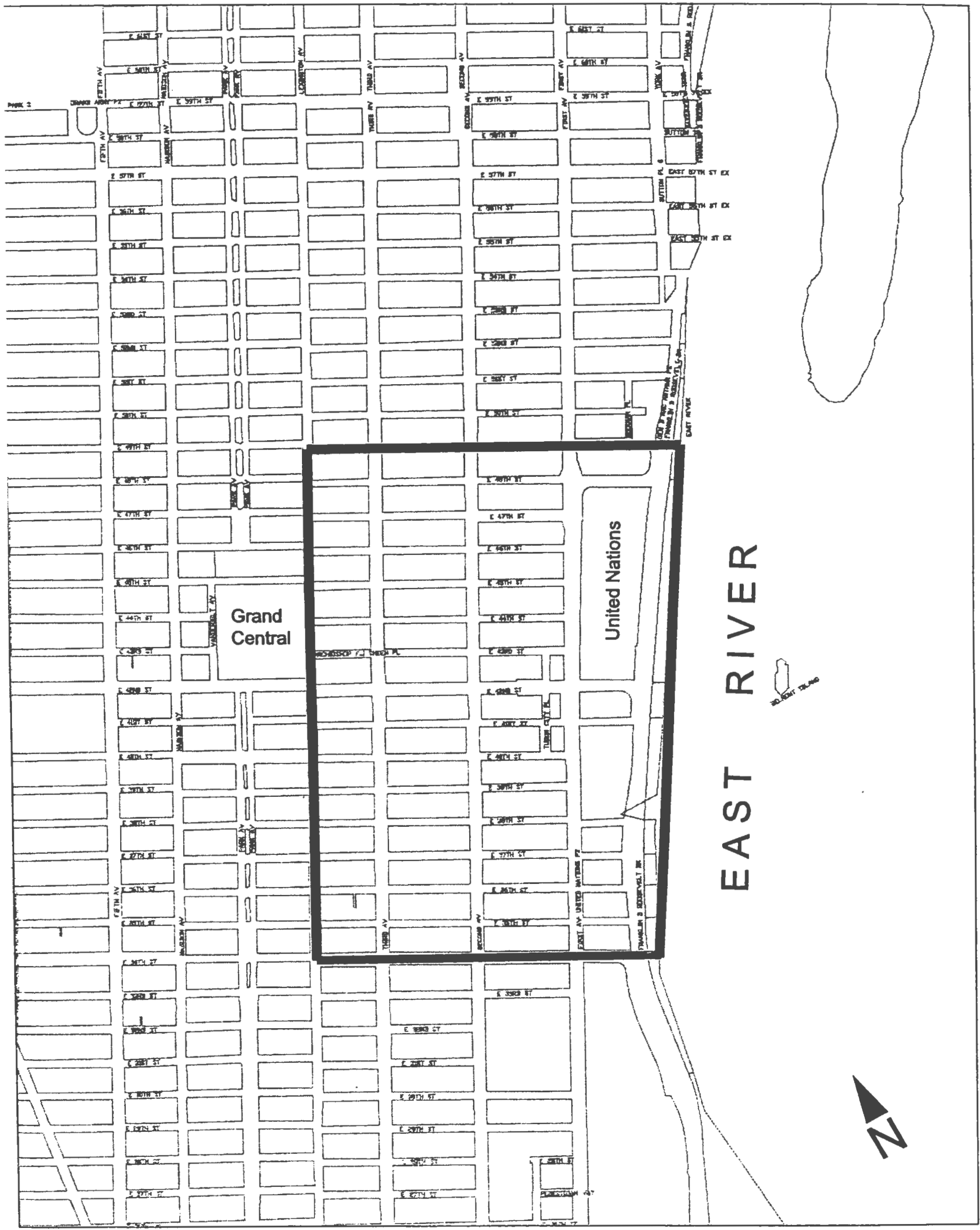


located to the east of Third Avenue. The immediate area encompassing the UN Headquarters campus is a dense mix of residential and institutional uses. Many permanent missions, UN programmes and funds, specialized agencies, consular uses, and NGO's are located on the blocks immediately surrounding the UN. However, almost all remaining potentially viable opportunities for new office development within this area are limited and have implicit disadvantages. Two of the main constraints of many potential construction sites are existing zoning restrictions and the lack of available development rights to further improve a site.

Many potential development sites immediately surrounding the UN Headquarters campus are within C1-9 zoning districts, lower commercial density zoning districts. As shown in Figure 3-5, much of the Second Avenue commercial corridor and the area between East $36^{\text {th }}$ and East $40^{\text {th }}$ Streets between First and Third Avenues is zoned C1-9, as well as a few city blocks directly north of Bellevue Medical Center. C1 zoning districts generally accommodate retail and personal service shops needed within residential neighborhoods. They favor residential and community facility development over commercial development and permit a maximum FAR of 10.0 for residential and/or community facility development, and a maximum FAR of only 2.0 for commercial development.

A second major constraint for office space development is that many undeveloped and/or potentially available sites within the study area are designated public parks or lack development rights. The development of a public park is a very lengthy and tedious process that requires several state and city actions and approvals. For example, the demapping of an existing park requires State legislative approval, and both the demapping of an old park and mapping of the new park require City review under the Uniform Land Use Review Procedure (ULURP). A suitable replacement park site must also be identified and set aside as public park land. This replacement park must be a one for one substitution, and generally must improve upon the existing recreational facilities for which it is intended to replace. Other potential development sites within the study area are "soft sites" or improved sites that have already been developed at a density below what zoning allows. However, many of these "low density sites" in the area are no longer able to be further developed, as they have transferred some or all of their development rights to adjacent parcels to add the allowable floor area.

Figure 3-6 and Table 3-21 provide an updated list of some of the available sites that could potentially be developed as commercial office space. Most of the listed sites were identified in the 1998 Urbitran Study and are currently vacant properties or used as parking facilities. Three of the listed sites (four properties) are the former Con Edison properties that have recently been acquired by the FMS East River Associates, LLC.

The first listed property in Table 3-21 is a fenced open space area located over the Queens Midtown Tunnel entrance (Midtown Plaza) between East $36^{\text {th }}$ and East $37^{\text {th }}$ Streets, just north of St. Vartans Park. It is zoned R8 and would require a special permit or need to be rezoned to a commercial zoning district to accommodate a potential office use (possibly C1-9). The future developer of this site would also need to acquire the air rights over the tunnel entrance to improve the site. In addition, developing an office building over the Queens Midtown Tunnel may also present safety and security concerns for the building's future inhabitants, which may require special, costly security provisions and amenities. Although this site presents several challenges, would be costly to develop, and requires several state and city approvals, the property is approximately 39,000 sf and currently has no real utility. The site is closed to the public and has no existing amenities. 


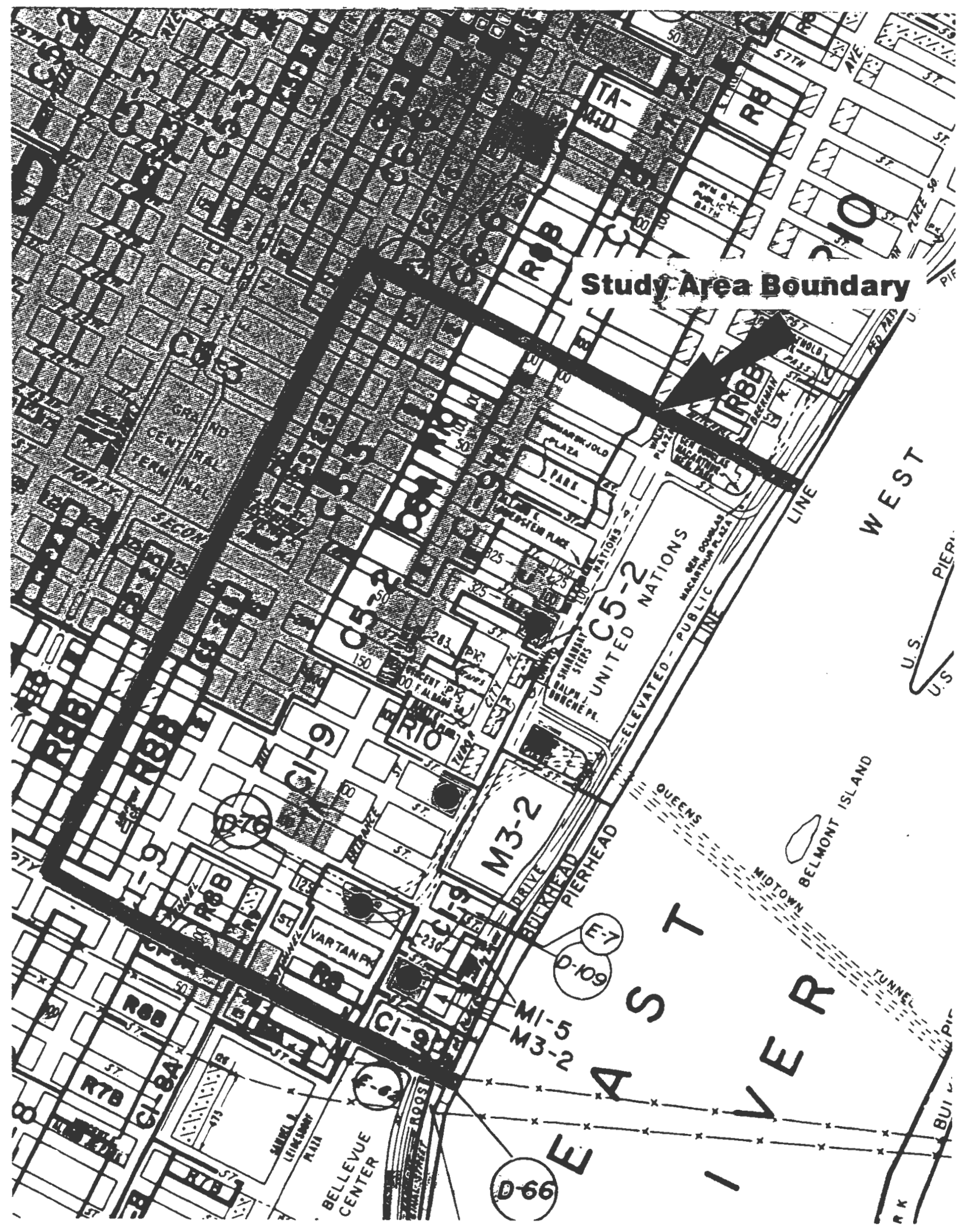


Potential Development Sites within the Immediate Vicinity of the UN Headquarters Campus

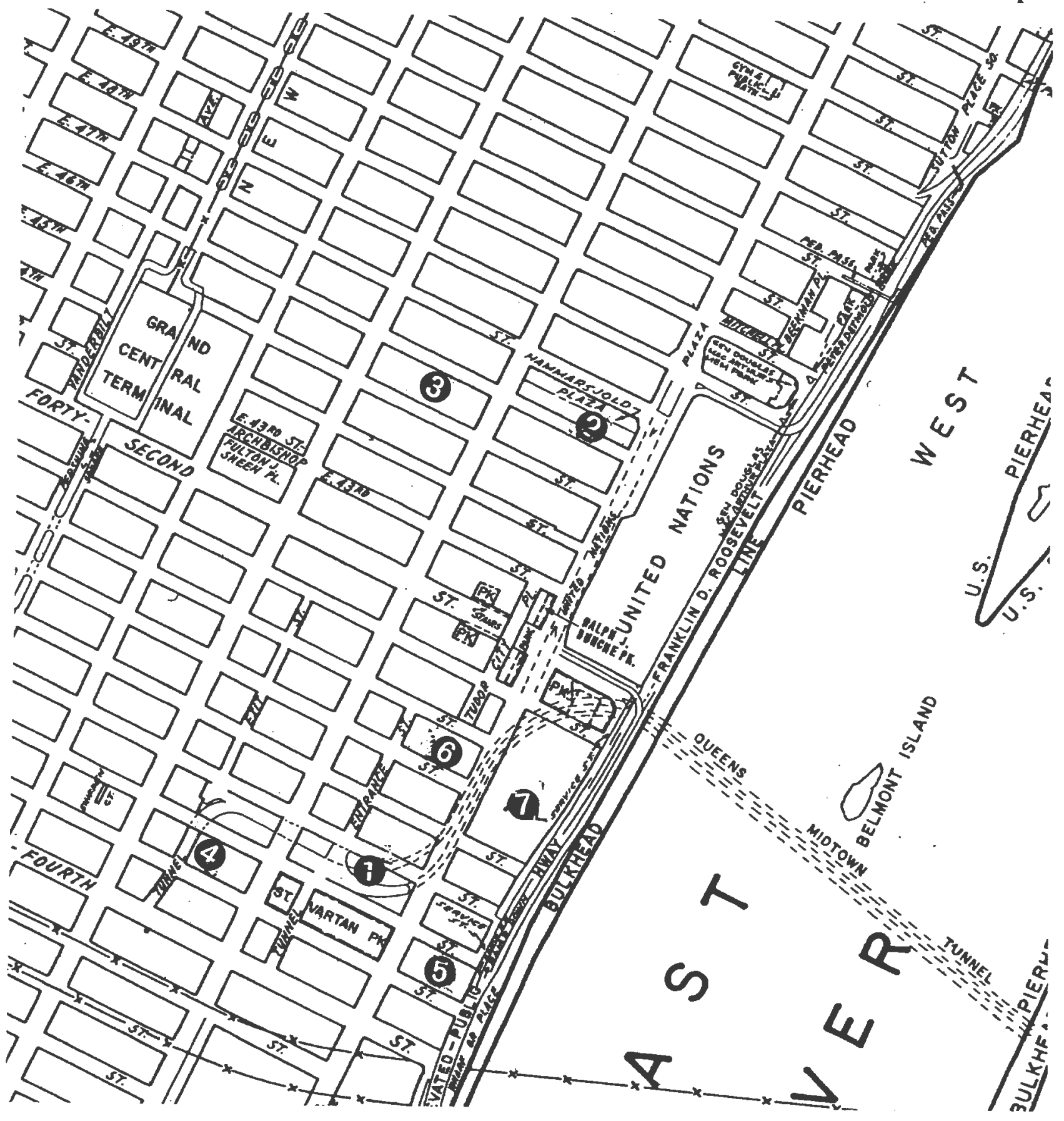

Legend: Potential Development Sites

1. Mid-Tunnel Plaza, between E. $36^{\text {th }} \&$ E. $37^{\text {h }}$ Streets

2. 344 E. $46^{\text {th }}$ Street, between $1^{\text {st }} \& 2^{\text {nd }}$ Avenues

3. 210 E. $45^{\text {th }}$ Street, between $2^{\text {nd }} \& 3^{\text {rd }}$ Avenues

4. $237 E$. $36^{\text {th }}$ Street, between $2^{\text {nd }} \& 3^{\text {rd }}$ Avenues

5. $6161^{\text {st }}$ Avenue, between E. $35^{\text {th }} \& E$. $36^{\text {th }}$ Streets

6. $6851^{s t}$ Avenue, between E. $39^{\text {th }} \&$ E. $40^{\text {th }}$ Streets

7. $6661^{\text {st }}$ Avenue $\& 7081^{\text {st }}$ Avenue, between E. $38^{\text {th }} \&$ E. $41^{\text {st }}$ Streets 
Table 3-21: Potential Sites for New Office Space Construction

\begin{tabular}{|c|c|c|c|c|c|c|c|}
\hline & $\begin{array}{l}\text { Approximate } \\
\text { Location }\end{array}$ & $\frac{\text { Block, }}{\text { Lot }}$ & $\frac{\text { Zoning/ }}{\text { Max. FAR }}$ & $\frac{\text { Lot Area }}{\underline{\text { SF }}}$ & $\frac{\text { Max. SE }}{\text { Possible }}$ & $\begin{array}{c}\text { Current } \\
\text { Use }\end{array}$ & Owner \\
\hline Mid-Tunnel Plaza & $\begin{array}{l}B / w E 36^{\text {th }} \& E 37^{\text {th }} \\
\text { St, west of } 1^{\text {th }} \text { Ave }\end{array}$ & $\begin{array}{l}942 \\
p / o 1\end{array}$ & $\begin{array}{c}\text { R8 } \\
\text { RE- } 6.0\end{array}$ & 39,000 & $\begin{array}{l}234,000 \\
\text { (RE use) }\end{array}$ & Vacant & $\begin{array}{l}\text { MTA/ } \\
\text { TBTA }\end{array}$ \\
\hline 344 E $46 \mathrm{St}$ & $\begin{array}{l}\text { Along south side of } \\
\text { E } 46 \mathrm{St}, \mathrm{B} / w 1^{n} \& \\
2^{\text {nd }} \text { Ave }\end{array}$ & $\begin{array}{c}1338 \\
31\end{array}$ & $\begin{array}{c}\text { C5-2 } \\
\text { CO- } 10 \\
\text { CF-10 }\end{array}$ & 4,000 & 40,000 & Vacant & $\begin{array}{l}\text { Gov't } \\
\text { of Turkey }\end{array}$ \\
\hline $210 \mathrm{E} 45 \mathrm{st}$ & $\begin{array}{l}\text { Along south side of } \\
\text { E } 45 \text { St, B/w } 3^{\text {sd }} 8 \\
2^{\text {vd }} \text { Ave }\end{array}$ & $\begin{array}{c}1318 \\
44\end{array}$ & $\begin{array}{c}\text { C6-4 } \\
\text { CO- } 10 \\
\text { CF }-10\end{array}$ & 1,670 & 16,700 & Vacant & $\begin{array}{l}\text { SLG } 711 \\
\text { Fee LLC }\end{array}$ \\
\hline 237 E. $36.5 t$ & $\begin{array}{l}\text { Along north side of } \\
\text { E } 36 \mathrm{St}, \mathrm{B} / \mathrm{w} 2^{\text {nd }} \& \\
3^{\text {rd }} \text { Ave }\end{array}$ & 917,21 & $\begin{array}{l}\mathrm{C} 1-9 \\
\mathrm{CO}-2 \\
\mathrm{CF}-10\end{array}$ & 5,800 & $\begin{array}{c}11,600 \\
\text { (CO use) }\end{array}$ & $\begin{array}{l}\text { Parking } \\
\text { Lot }\end{array}$ & $\begin{array}{l}S \& M \\
\text { Enterprise }\end{array}$ \\
\hline $6161^{* A v e}$ & $\begin{array}{l}\mathrm{B} / \mathrm{wE} \cdot 35^{\text {th }} \& \mathrm{E} 36^{\text {th }} \\
\text { St., east of First } \\
\text { Ave. }\end{array}$ & 967,1 & $\begin{array}{l}\mathrm{Ml}-5 \\
\mathrm{CO}-5.0 \\
\mathrm{CF}-6.5\end{array}$ & 66,000 & $\begin{array}{l}330,000 \\
(\mathrm{CO} \text { use })\end{array}$ & Vacant & $\begin{array}{c}\text { FMS } \\
\text { Former } \\
\text { ConEd Site }\end{array}$ \\
\hline $6851^{\circ}$ Ave & $\begin{array}{l}\text { West side of } 1^{\text {th }} \text { Ave, } \\
B / w E 39^{\text {th }} \& E 40^{\text {th }} \\
\text { St }\end{array}$ & 945,33 & $\begin{array}{c}\text { C1-9 } \\
\text { CO-2.0 } \\
\text { CF } 10.0\end{array}$ & 80,000 & $\begin{array}{l}160,000 \\
(\mathrm{CO} \text { use })\end{array}$ & Vacant & $\begin{array}{c}\text { FMS } \\
\text { Former } \\
\text { ConEd Site }\end{array}$ \\
\hline $\begin{array}{l}6661^{s} \text { Ave \& } \\
7081^{*} \text { Ave }\end{array}$ & $\begin{array}{l}\text { East side of } 1^{t t} \text { Ave, } \\
\text { B/wE } 38 \text { \& E } 41 \mathrm{St}\end{array}$ & 970,1 & $\begin{array}{c}\mathrm{M} 3-2 \\
\mathrm{CO}-2.0\end{array}$ & 277,000 & $\begin{array}{c}554,000 \\
(\text { CO use })\end{array}$ & $\begin{array}{l}\text { Former } \\
\text { Electricity } \\
\text { Plant }\end{array}$ & $\begin{array}{c}\text { FMS } \\
\text { Former } \\
\text { ConEd Sites }\end{array}$ \\
\hline
\end{tabular}

CF: Community Facilities Uses; CO: Commercial Uses; \& RE: Residential Uses

DCAS: New York City Department of City wide Administrative Services

MTA/TBTA: Metropolitan Transit Autbority, Bridges and Tunnels Transit Authority

The next property listed in Table 3-21 is a vacant parcel situated along the south side of East $46^{\text {th }}$ Street, between First and Second Avenues, directly south of the Dag Hammarskjold Plaza. It is located one block west of the UN Headquarters campus, and abuts high-rise office buildings along the west side of First Avenue that currently accommodate permanent mission space, consular uses, and several NGO's. The parcel is zoned C5-2 and would potentially allow a commercial office building with a maximum FAR of $40,000 \mathrm{sf}$. However, the site is currently privately-owned by the government of Turkey.

The property at 210 East $45^{\text {th }}$ treet is located two blocks west of the UN Headquarters campus along the south side of East $45^{\text {th }}$ Street, between Second and Third Avenues. It is located adjacent to office towers along the east side of Third Avenue, and low-rise residential uses with ground floor retail on East $45^{\text {th }}$ Street. Although this parcel is relatively small (approximately 1,670 sf) and is privately-owned, it is zoned C6-4 and would potentially allow a commercial office building with a maximum FAR of 16,700 sf. An office building of this size could potentially serve as a permanent mission to the UN, consular office space, or NGO office space.

The fourth property listed in Table 3-21 is a privately-owned parcel that currently serves as a licensed parking lot facility. It is a mid-block site along the north side of East $36^{\text {th }}$ Street between Second and Third Avenues, 
approximately seven blocks to the south and two blocks to the west of the UN Headquarters campus. It is located directly above the Queens Midtown Tunnel exit and is surrounded by residential uses. The site is zoned C1-9 and would potentially allow a commercial office building with a maximum FAR of 11,600 sf. Similarly to the property at 210 East $45^{\text {th }}$ Street, a commercial development at this site could accommodate a permanent mission, consulate, or NGO use. However, like the Midtown Plaza property, the development of this parcel would be costly and would require the air rights over the Queens Midtown tunnel exit. This potential site may also present several safety and security concerns for the building's future inhabitants.

\section{The Former Con Edison Sites}

The four former Con Edison properties identified in Table 3-21 are the three largest potential sites for new construction and represent some of the better development opportunities in the study area (see Figure 3-7). In total, these four properties occupy approximately 9.2 acres and represent one of the largest tracts of undeveloped land (soft-sites) in Manhattan. They also represent some of the more viable development sites for UN-related uses, permanent missions, and consulates. Office development on a portion of these four sites could potentially accommodate conference and meeting facilities for the UN Secretariat, new permanent mission space and new consular space, NGO offices, and/or other UN-related uses. Although the Con Edison properties are currently isolated from other significant commercial development in the area, each site permits commercial office development as-of-right. In addition, all of the former Con Edison sites are in close proximity (3-7 blocks) of the UN Secretariat Building.

The following bulleted list provides an assessment of the potential office development that could be accommodated on the former Con Edison properties under current zoning regulations.

\section{- 616 First Avenue}

616 First Avenue is the former Con Edison property that is located the furthest from the UN Headquarters campus. It is located to the east of First Avenue between East $35^{\text {th }}$ and East $36^{\text {th }}$ Streets, directly southeast of the Queens Midtown Tunnel entrance. The site is currently located within a light manufacturing district and is zoned M1-5. Under the site's present M1-5 zoning, a commercial office building with a maximum FAR of 330,000 sf could potentially be built as-of-right on-site. As the site is located directly west of St. Vartan Park, the property at 616 First Avenue could also represent a viable replacement park site.

\section{- 666 First Ave \& 708 First Avenue}

The properties at 666 First Avenue and 708 First Avenue, which contain the former Con Edison electricity plant, are composed of three City Tax Lots located between East $38^{\text {th }}$ and East $40^{\text {th }}$ Streets. In total, these two properties consist of more than 270,000 sf of space and represent the largest under-developed site within the study area. Currently, entire site is zoned M3-2 and would permit an office building with a maximum FAR of $544,000 \mathrm{sf}$. As such, these two properties have the unique potential to accommodate a significant, if not unlimited, amount of the UN System's and/or permanent missions/consular uses' future office and/or conference facility needs in one small geographic area.

\section{- 685 First Avenue}

The property at 685 First Avenue is the smallest of the former Con Edison properties. It is located directly west of the former Con Edison electricity plant, between East $39^{\text {th }}$ and East $40^{\text {th }}$ Streets. Currently, the site is zoned C1-9 and would potentially permit a commercial office building with a maximum FAR of 160,000 sf.

Currently, FSM East River Associates, LLC is preparing an Environmental Impact Statement (EIS) pursuant to City Environmental Quality Review (CEQR) for the disposition of these four properties. Although no concrete build program has been determined at this time for these former Con Edison sites, most likely FSM will 
Assessment of the Future Office Space Needs of the International Community Figure 3-7 Former Con Edison Sites

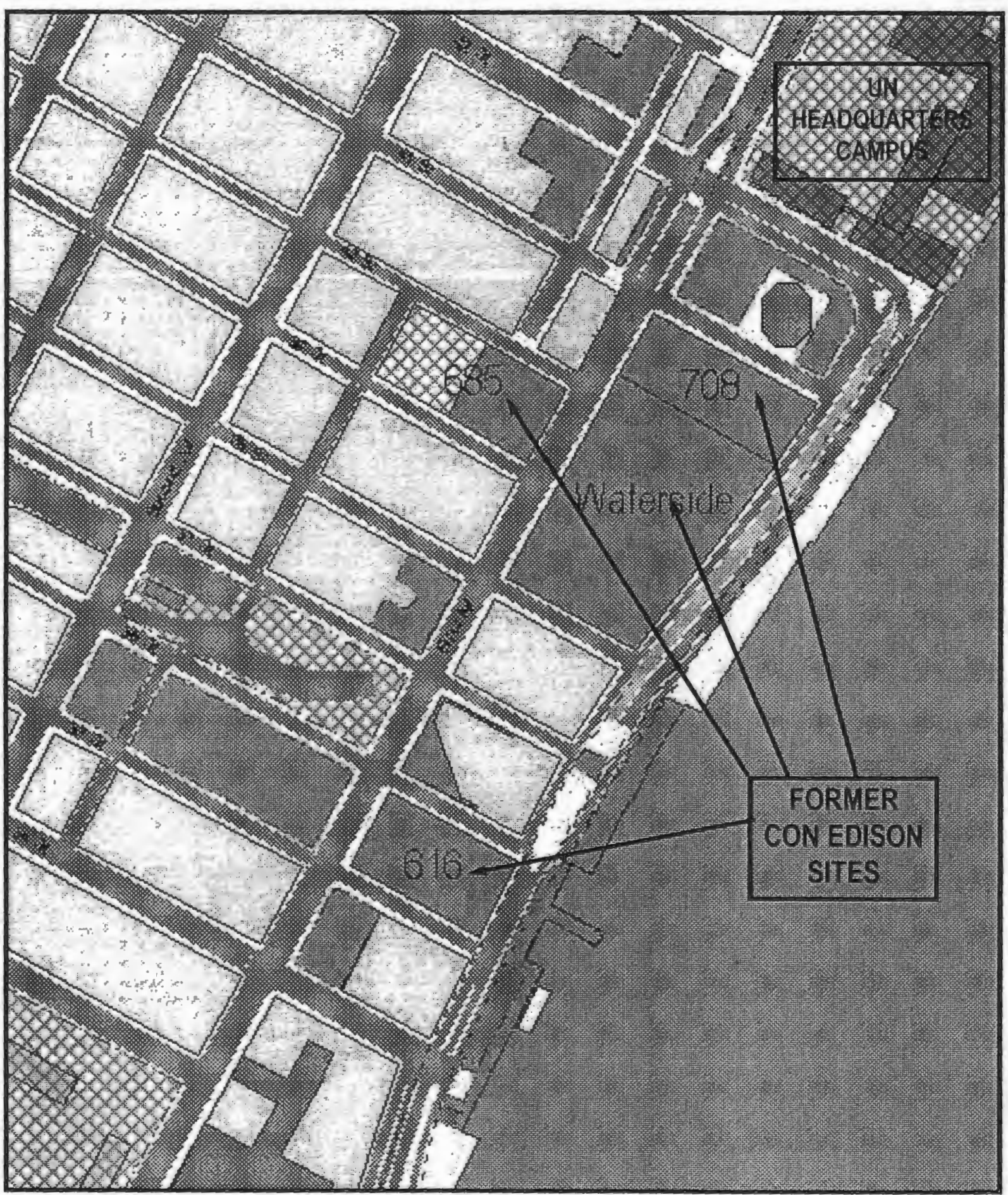


construct a mixed use development with an office and residential component. FSM is considering office development along the north side of the 666-708 First Avenue site. The proposed Build Year for this mixed use development is anticipated to between 2007 and 2011 . Pei Cobb Freed \& Partners, and Skidmore, Owings \& Merrill were selected as the site's architects.

Six other potential development sites were identified in the 1998 Urbitran Study but were not included within this survey. One of the sites identified within the 1998 study was a portion of Robert Moses Playground at the Queens Midtown Tunnel exhaust site. As this site is a portion of an existing City park, the site cannot readily be developed without the approval of several State and City actions, and the designation of a replacement park. As such, the site was not considered as a viable development site. Three other sites identified in the 1998 study were the former Boys Club site at 763-773 First Avenue, which have since been developed into two 5-story office buildings and one 6-story office building. Two of the office buildings are currently owned by the City and the 6-story building is owned by the Government of Brunei. Although these sites are located directly west of the UN Headquarters campus, they are relatively small parcels (less than 10,000 gsf) with little commercial development potential. In addition, the two City-owned parcels transferred $10 \mathrm{FAR}$ of their development rights to the lot that contains One UN Plaza (both sites currently have a maximum FAR of 5.0). The remaining two sites identified in the 1998 Study have since been developed into commercial office uses (633 Third Avenue and 605 Third Avenue) that accommodate several permanent missions, foreign consulates, NGOs, or other UNrelated programmes/funds/agencies.

\section{B. Building Rental/ Acquisition Opportunities}

As mentioned previously, Midtown is one of the largest and most competitive commercial office markets in the country, if not the world. It is also recognized as one of the more desirable and expensive office markets. Prior to September 11, 2001, less than 7 percent of Midtown North's office market was available with average asking rents of approximately $\$ 64.00$ per square foot. Since September 11 , available office space has slightly increased, as both direct and indirect office space have returned to the market, and as companies continue to downsize and forego future expansion plans. Although several displaced companies from Downtown have relocated to commercial office space in Midtown, availability rates continue to increase as significant amounts of commercial office space return to the market. However, although commercial office space continues to return to the market, there are very few large continuous blocks of office space available throughout Manhattan, particularly in Midtown. Class A office space is also very limited.

Real estate market estimates from December 31, 2001 predict that approximately 8 percent (14.6 million square feet) of Midtown North's office market will be available within the next 6 to 18 months. As available office space has increased, average asking rents for commercial office space have fallen approximately 10 percent to an average asking rent of $\$ 58.00$ per square foot in Midtown. ${ }^{39}$ However, as the immediate area surrounding the UN consists predominantly of residential and institutional uses, there is a very limited supply of large commercial office buildings and very few significant blocks of continuous office space available for lease. Much of the office facilities are also older, lower quality, and less expensive than the majority of Midtown's office stock. However, they are still more expensive than the majority of commercial facilities in Midtown South or Downtown.

Appendix D provides a detailed list of significant commercial buildings within the immediate area surrounding the UN that currently have available office space. From that list, Table 3-22 highlights a selection of buildings 
that currently have available office space that might be of particular interest to the UN, its affiliated programmes and funds, specialized agencies, permanent missions, and/or consular offices. Most likely permanent missions, consular uses, UN programmes and funds, specialized agencies, and the UN Secretariat will (continue to) lease commercial space due to the limited number of viable soft-sites in the immediate area of the UN.

Approximately 2.1 million square feet of commercial office space is available within the immediate area of the UN (see Appendix D). Most of this available space, however, is relatively small in size, at less than 20,000 sf. Currently, there are nine commercial office spaces available that are larger than 20,000 sf and nine other office spaces that are larger than $30,000 \mathrm{sf}$. Average asking rents for this available office space range from approximately $\$ 27.00$ to $\$ 89.00$ per square foot.

Several of the office buildings listed in Table 3-22 with available space (as of December 2001) currently house numerous permanent missions, consular offices, UN-related entities, and/or NGOs, including $866 \mathrm{UN}$ Plaza, 747 Third Avenue, 800 Second Avenue, 801 Second Avenue, 866 Second Avenue, and 885 Second Avenue. As commercial, retail, and office uses are predominantly concentrated along Third Avenue and to the west, most of the larger office buildings and the office buildings with available office space are located along Third Avenue and the commercial corridor of East $42^{\text {nd }}$ Street. A few office buildings with available office space are located along East $45^{\text {th }}$ Street (UN Plaza) and Second Avenue. 
Table 3-22:

A Highlighted Sample of Available Office Space in the Vicinity of the UN Headquarters within CB6 Boundaries (December 2001)

\begin{tabular}{|c|c|c|c|c|}
\hline Office Bldg. & Tot. SF & Tot. SF Avail.* & Avg, Asking Rent & Owner \\
\hline 866 UN Plz. & 345,000 & 7,800 & negoriable & Meadik Realty \\
\hline 405 Lex. Ave. & 1.2 million & 181,200 & $s 67$ to $s 89 /$ sf & 405 Lex. LLC \\
\hline 6663 Ave. & 700,000 & 65,500 & $S 58$ to $S 70 / s f$ & 405 Lex. LLC \\
\hline 6223 Ave. & 1.0 million & 92,100 & $S 45$ to $S 59 / \mathrm{st}^{\circ}$ & $6223^{\text {rd }}$ Assoc. \\
\hline 6333 Ave. & 1.0 million & 96,500 & negotiable & $6333^{\text {rd }}$ Assoc \\
\hline 6053 Ave. & 1.4 million & 156,500 & $\mathrm{~S} 58 / \mathrm{sf}$ & Fisher Bros. \\
\hline 6553 Ave. & 375,000 & 33,200 & $\mathrm{~s} 35$ to $s 60 / \mathrm{sf}$ & Durst Org. \\
\hline 6753 Ave. & 295,000 & 45,200 & $\mathrm{~S} 58 / \mathrm{st}^{\circ}$ & Durst Org. \\
\hline 6853 Ave. & 650,000 & 154,700 & $S 40$ to $\$ 65 / \mathrm{sf}$ & $\begin{array}{c}\text { Blackarce Cap. \& } \\
\text { Argent Venture }\end{array}$ \\
\hline 6003 Ave. & Not Available & 14,400 & negotiable & $6003^{\text {rd }}$ Assoc \\
\hline 6303 Ave. & 250,000 & 28,300 & $s 36$ to $\$ 48 / s f^{\circ}$ & $6303^{\text {rd }} \mathrm{CP}$ \\
\hline 7083 Ave. & 592,000 & 50,500 & $S 47$ to $\$ 53 / \mathrm{sf}$ & Clemens Properties \\
\hline 7113 Ave. & 500,000 & 23,100 & $s 48$ to $S 55 /$ sf & $7113^{\text {rd }}$ Assoc. \\
\hline 7333 Ave. & 550,000 & 9,200 & negotiable & Durst Org. \\
\hline 7473 Ave. & 390,000 & 50,000 & $\mathrm{~S} 52$ to $\mathrm{S} 59 / \mathrm{sf}$ & Kaufman Org. \\
\hline 8012 Ave. & 150,000 & 19,300 & negotiable & Crystal Realty \\
\hline 8852 Ave. & 785,000 & 29,000 & $\$ 48 / \mathrm{sf}$ & Duet Realty \\
\hline 8662 Ave. & 90,000 & 10,000 & $s 53$ to $\$ 57 /$ sf & N/A \\
\hline 8002 Ave. & 290,000 & 55,000 & negotiable & Amapl Realty \\
\hline 205 E. $42 \mathrm{St}$ & 470,000 & 1,200 & negotiable & Durst Org. \\
\hline 220 E. $42 \mathrm{St}$ & 1.1 million & 24,900 & \$55/sf & 220 News LLC \\
\hline 823 UN Plz. & 150,000 & $\underline{5,000}$ & negotiable & $A D L$ \\
\hline Total & & 1.12 million & & \\
\hline
\end{tabular}


TASK 4

INTERNATIONAL COMMUNITY'S SPACE NEEDS ASSESSMENT

COMMERCIAL OFFICE SPACE

\section{INTRODUCTION}

The purpose of this task is to provide an assessment of the future commercial space needs of the UN System, permanent missions, and foreign consulates in New York City. Through examining both the past and present employment levels and office space utilization of the UN System, permanent missions, and foreign consulates, this task provides employment forecasts and estimated future office space needs for the international community in New York City, as well as predicts the ongoing and future trends in commercial space utilization that could affect the United Nations and affiliated uses, as well as permanent missions and consular uses.

Information for this report was compiled via paper record searches, computer databases, secondary data sources, and other various technical studies. As interviewing the individual permanent missions and foreign consulates demanded too many resources and the majority of foreign countries are not at liberty to divulge any information about their existing facility needs or forecast future employment levels and/or office space needs, contacting permanent missions and consulates was outside the scope of this project. The vast majority of the material compiled for this task is derived from secondary sources, including the Register of Foreign Consulates and Associated Government Offices in New York (2001, 1989, \& 1980 editions), Permanent Mission to the United Nations (1999, 1988, \& 1980 editions), and The Economic Impact of the Diplomatic Community on New York (1989, 1981,\& 1977 editions). The CoStar real estate database and other various real estate surveys were also utilized to identify the amount and type of commercial office space occupied by permanent missions and foreign consulates. Signature Properties real estate services also assisted in describing the spatial utilization patterns of the international community. In addition, title searches were conducted to identify any tenure patterns throughout the 1980's and 1990's.

\section{THE UN SYSTEM EMPLOYMENT TRENDS AND SPACE UTILIZATION}

\section{A. The United Nations Secretariat Staff}

As presented within Task 1, the diverse day-to-day work of the UN organization is carried out by the UN Secretariat, a professional staff of international civil servants. Although the UN Secretariat staff is largely concentrated at the UN Headquarters seat in New York City, the UN Secretariat maintains a significant presence in several regional offices and throughout the world at various field offices. The UN Secretariat staff serves, administers, and implements the programs and policies formulated by the other principal organs of the UN across the globe.

In general, the UN Secretariat staff is composed of two classifications of workers, those who are employed under the regular annual budget and those who are paid out of extra budgetary funds or voluntary 
contribution funds for specific projects. The UN staff who are employed under the regular budget are permanent civilian staff located throughout the world at various headquarter, regional, and local offices. They make up the bulk of UN employment and represent approximately two-thirds of the UN's current staff. They also are relatively constant in number with little growth or fluctuation from year to year. Those UN workers who are employed through extra budgetary funds are largely temporary or project-based international and local civilian staff who are hired to work on specific peacekeeping operations for the UN in specific parts of the globe (UN Department of Peacekeeping Operations- Field Service). They primarily work in the field at the local level in conjunction with military forces and civilian police, helping to create and establish stable and secure local governments. The total number of UN peacekeepers employed at any one time is dependent on current world events, and varies according to the complexity and quantity of ongoing peacekeeping operations. Currently, the UN Secretariat employs approximately 8,900 people under the regular budget and more than 5,700 people under specially funded programs or projects.

\section{UN Peacekeepers}

The peacekeeping technique or strategy is a unique tactic originally devised and further defined by the UN organization. The UN's first peacekeeping mission or field operation began in 1948, when approximately 36 military observers were sent to the Middle East to oversee a fragile truce between the Arab nations and Israel. Since then more than 750,000 individuals (the majority of them soldiers) have served in 55 UN peacekeeping missions around the world. These peacekeeping missions have involved such diverse operations as: patrolling buffer areas; monitoring cease fires; defusing conflicts; promoting the search for durable political settlements; delivering humanitarian assistance; and assisting in the development of peace agreements, as well as advising and training local governments and inhabitants.

The UN peacekeepers' primary function is to serve as preventative deployments to control and alleviate conflict in troubled areas or regions. They work closely with the regular budget field staff of UN specialized agencies, UN programmes and funds (e.g. UNICEF, UNDP, UNOPS etc.), and other UN offices to contribute to the reconciliation and reconstruction of an area in turmoil. They assist societies devastated by war and support balanced and tolerant institution-building. Each peacekeeping mission is unique and specifically tailored to meet the requirements of each new UN operation.

Since the UN's inception in 1945, the UN's peacekeeping operations have diversified and adapted to the changing political landscape of the world. Throughout the last sixty years, they have become increasingly complex, and have evolved to help resolve the unique issues and disputes surrounding present-day conflicts. Although UN peacekeeping missions originated as predominately military operations for handling interstate conflicts, the UN's peacekeeping operations are increasingly becoming multi-dimensional, involving the strengthening of local institutions and often the development of transitional governments. UN peacekeeping missions are increasingly being applied to intra-state conflicts and civil wars between multiple armed factions with varying political objectives and fractured command lines.

In addition to being dynamic and fluid with current world events, UN peacekeeping missions have also expanded in size and number, and changed in nature. As shown in Table 4-1, the vast majority of peacekeeping missions undertaken by the UN to date were initiated during the 1990's. Approximately 70 percent (or 38) of the UN peacekeeping missions were initiated within the last decade, a sharp increase from the three missions (5.5 percent of total) initiated in the 1980's. Nearly 30 percent (16) of UN peacekeeping missions are still in progress today (see Figures 4-1 and 4-2). Less than 30 percent of the UN's peacekeeping operations began prior to 1990. Currently, the UN has peacekeeping missions in the Democratic Republic of the Congo, Ethiopia and Eritrea, Sierra Leone, Western Sahara, East Timor, IndiaPakistan, Bosnia and Herzegovina, Cyprus, Georgia, Kosova, the Prevlaka Peninsula, Golan Heights, 
Figure 4-1

Completed and Ongoing Peacekeeping Missions

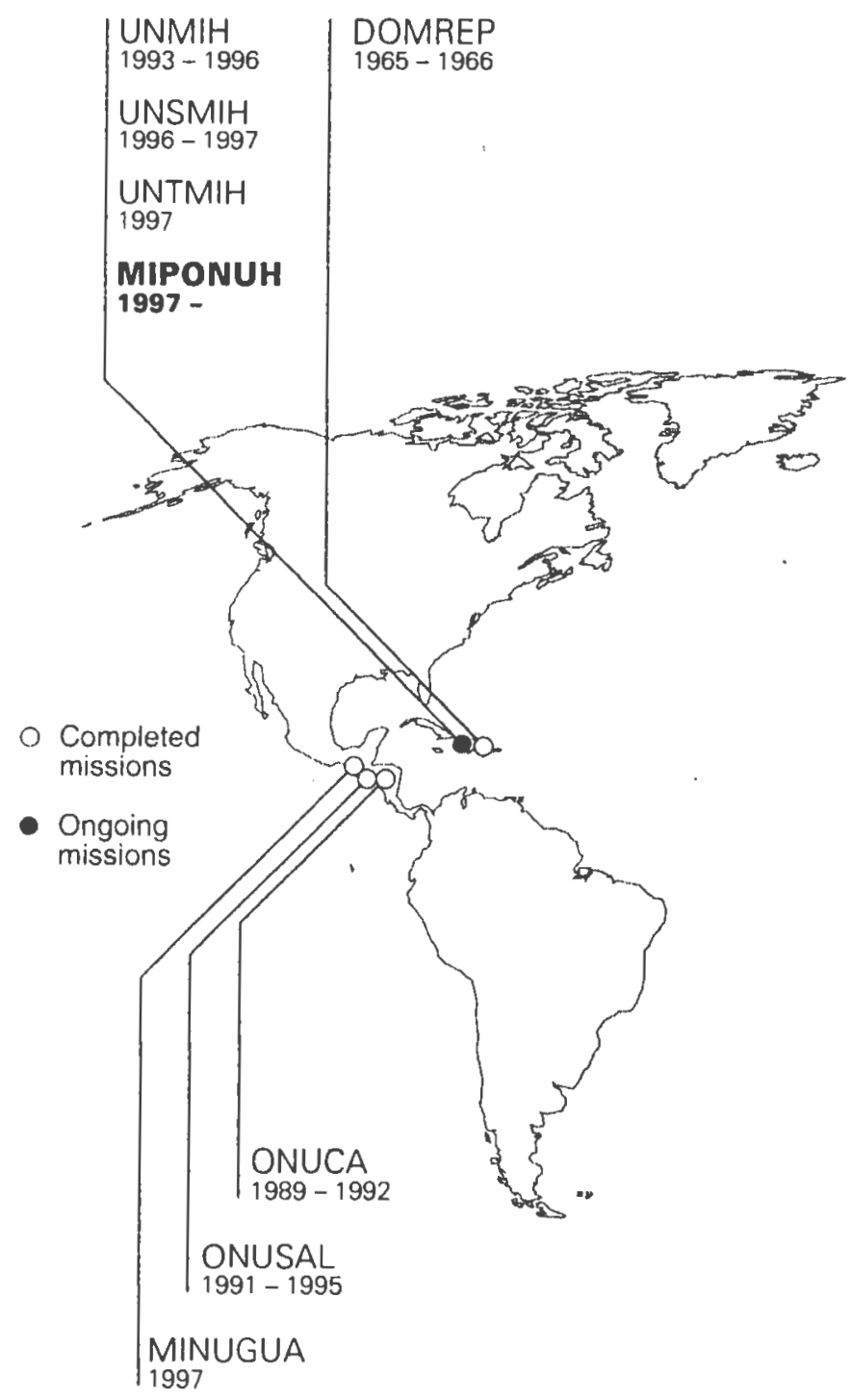

Map No. 3852.1(E) Rev. 15 UNITED NATIONS July 1998

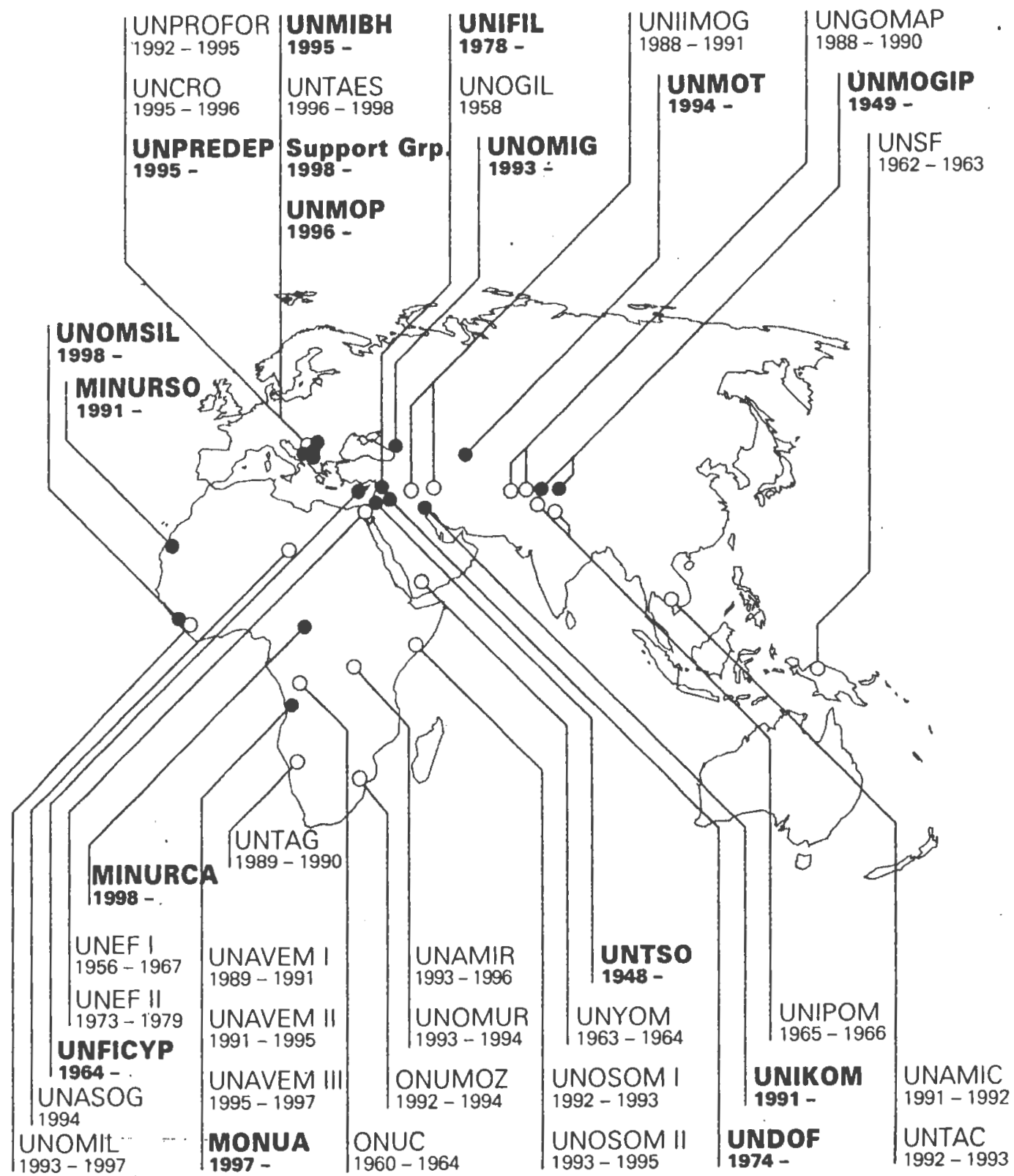

Department of Public Information Cartographic Section 
Current operations on 1 January 2001

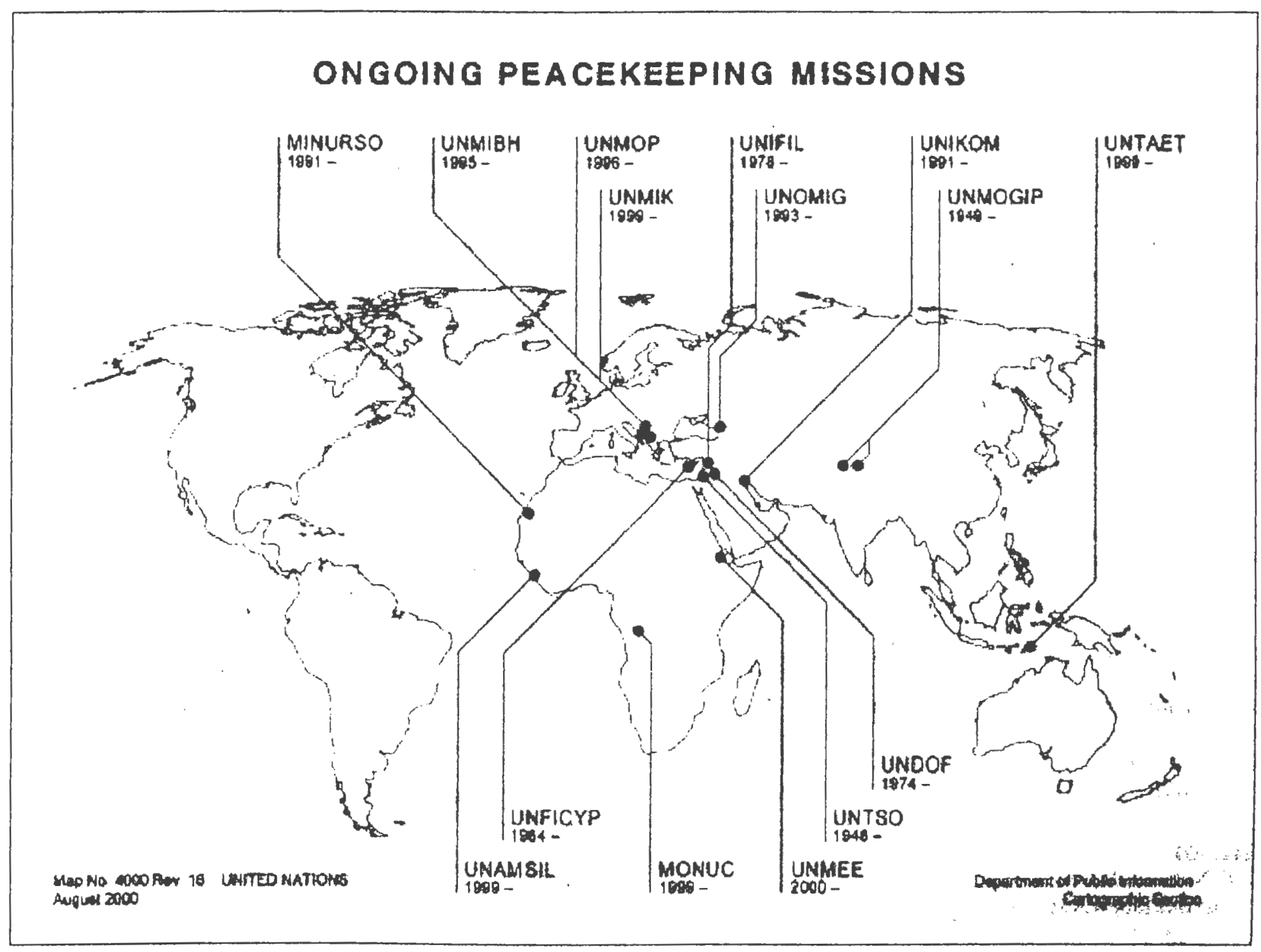


Iraq/Kuwait, Lebanon, and other various locations in the Middle East. Furthermore, the UN has also initiated an assistance mission in Afghanistan. This peacekeeping mission is focused on the recovery and reconstruction of Afghanistan.

Table 4-1: Peacekeeping Operations of the UN 1948-2000

\begin{tabular}{lcccc}
\hline Time Period & $\begin{array}{c}\text { No. of Missions } \\
\text { Initiated }\end{array}$ & $\begin{array}{c}\text { Percentage of Missions } \\
\text { between 1948-2000 }\end{array}$ & $\begin{array}{c}\text { Tot. No. of } \\
\text { Missions }\end{array}$ & $\begin{array}{c}\text { No. of Ongoing } \\
\text { Missions }\end{array}$ \\
$1948-1949$ & 2 & $3.6 \%$ & 2 & 0 \\
$1950-9$ & 2 & $3.6 \%$ & 4 & 2 \\
$1960-9$ & 6 & $10.9 \%$ & 9 & 3 \\
$1970-9$ & 3 & $5.5 \%$ & 6 & 3 \\
$1980-9$ & 3 & $5.5 \%$ & 8 & 5 \\
$1990-9$ & 38 & $69.1 \%$ & 43 & 5 \\
2000 & 1 & $1.8 \%$ & 17 & 16 \\
Total & 55 & $100 \%$ & & \\
\hline
\end{tabular}

Source: UN Nations (1999) 50 Years 1948-1998 UN Peacekeeping

The actual dynamics or composition of peacekeeping missions also has changed significantly. Although military operations continue to serve as the backbone for many ongoing peacekeeping operations, local and international civilian involvement within various peacekeeping missions has increased dramatically. By the mid-2020's, the civilian personnel involved with peacekeeping missions are expected to increase to approximately 12,500 people (data estimate includes both local and international workers and volunteers), an increase of approximately 1,000 people from current levels.

The few UN employees who are located at UN Headquarters in New York City and are directly involved with peacekeeping operations, primarily serve as the support staff for UN peacekeeping missions. They are the mangers and administrators for individual peacekeeping operations, and are in constant contact and communication with the field personnel of various missions. Their responsibilities include planning, tracking, and accounting/budget work. The actual size of this support staff at the UN Department of Peacekeeping Operations in New York City is dependent on the quantity and nature of ongoing peacekeeping missions in the field. Although the size of this administrative staff is significantly smaller than the number of peacekeepers in the field, the size of the support staff at the Department of Peacekeeping Operations is directly proportional to the size of current peacekeeping missions. In addition, the size of the support staff at UN Headquarters is also dependent on the status of a mission. When a field operation closes, there is a reduction in the staff at UN Headquarters, and when a new field operation begins there is an increase in the amount of staff at UN Headquarters. However, there is some lag time between the completion of a peacekeeping mission and the termination of all affiliated UN support staff at headquarters. Often some support staff at UN Headquarters will remain employed for six months to a year after a mission ends to complete the necessary budget and follow-up work associated with a particular operation. 
The UN Secretariat in New York-1990's-2000

Throughout the last decade, the UN Secretariat staff levels in New York City have remained relatively stable, fluctuating little between the years. Since 1992, the UN Headquarters staff has only grown by about four percent or approximately 200 employees. Most of these new employees at UN Headquarters were additional extra-budgetary staff working for various peacekeeping missions. As of December 2000, approximately 5,700 people (including both regular budget staff and UN support staff for peacekeepers) were employed at UN Headquarters in New York City (see Figure 4-3).

Although the UN organization has grown through the addition of several member states and the expansion of its services and efforts, the UN Headquarters staff has not experienced a significant increase in its employment levels within the last ten years. During the 1990's, the UN Headquarter's staff fluctuated by approximately 1,000 employees (18 percent), with its highest recorded employment level at approximately 6,000 workers in 1994, and its lowest at about 5,000 workers in 1998. Much of this fluctuation in United Nations Headquarters staff was as a result of the UN's increased involvement in peacekeeping operations throughout the world. However, as the majority of UN staff involved in peacekeeping operations work in the field on specific projects, the total increase in staff levels at UN Headquarters was minimal.

\section{Figure 4-3: UN Secretariat Staffing Level at UN Headquarters}

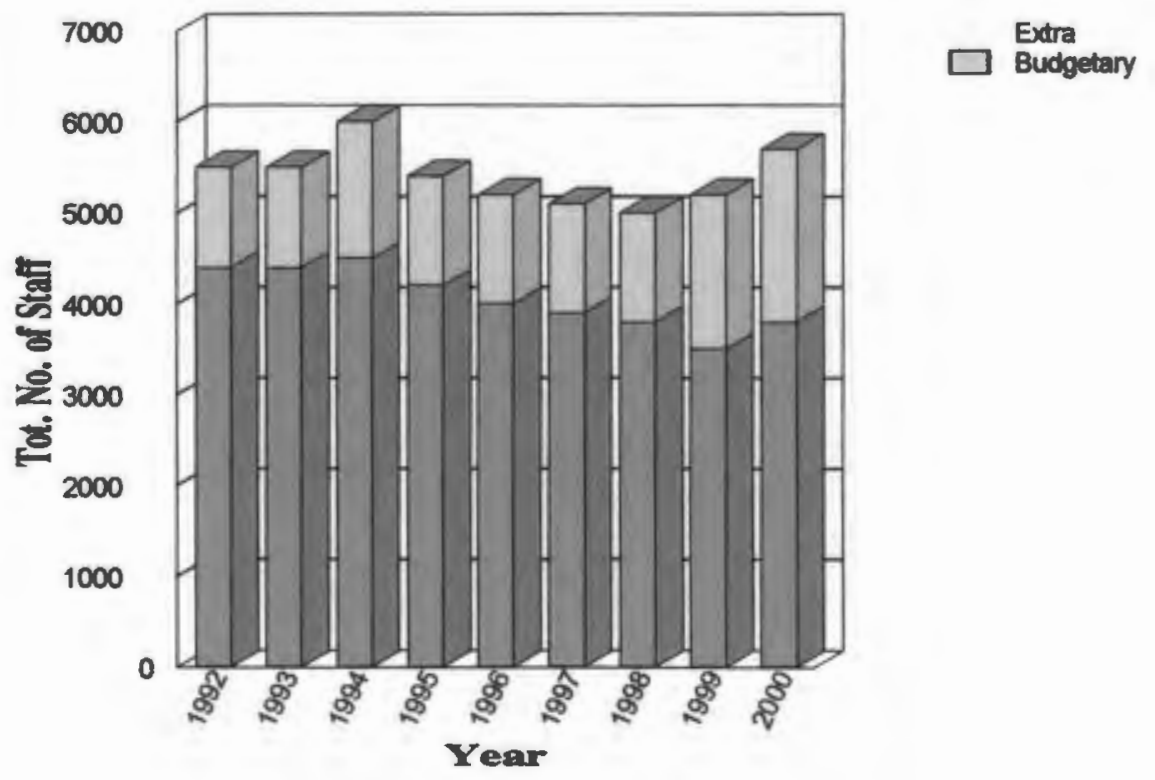

Source: UN Factlities Management Department

\section{Regular Budget Staff}

The bulk of UN Headquarter's staff is comprised of regular budget workers. More than two-thirds of the UN Headquarters staff are regular budget workers, while less than a third are extra-budgetary workers. Although employment levels for regular budget staff have experienced a downward trend since 1994, they have gone up slightly in 2000 to almost 1998 levels. As of 2000, approximately 3,880 of the UN Secretariat staff in New York City were permanent, regular budget workers. 
As shown in Figure 4-3, the UN Headquarter's regular budget staff has remained relatively constant throughout the last ten years. Employment levels for regular staff have only fluctuated by approximately 23 percent or 1,000 people since 1992. On average, employment levels have varied by 100 to 300 regular budget employees per year throughout the last ten years. The UN possessed its largest regular budget staff in 1994 (approximately 4,500 workers) and smallest in 1999 (approximately 3,500 workers).

\section{Extra-Budgetary Staff}

Approximately 1,820 people at the UN Headquarters are currently employed under extra-budgetary funds. Since 1992, the size of the UN's extra-budgetary staff has grown by approximately 72 percent. Although employment levels experienced a slight decline during the early 1990's and remained stable throughout much of the mid-1990's, employment levels for extra-budgetary staff have fluctuated by approximately 800 workers. The UN's extra-budgetary staff experienced its greatest increases in 1994 (approximately 36 percent) and in 1999 (approximately 41 percent). Since 1999, the UN's extra-budgetary staff has grown by more than 700 employees (approximately 58 percent).

\section{Forecast of Future Employment Levels within the $U N$}

Future employment levels at the UN Headquarters seat in New York City are difficult to forecast. As the UN Secretariat operates at an international scale, maintains field offices throughout the world, and organizes international peacekeeping missions, the future status of the UN Secretariat is highly dependent on the world's current events and political landscape. Currently, the UN organization has 191 permanent member states, several observer missions and liaison offices, and eighteen ongoing peacekeeping missions, as well as a total staff of approximately 14,600 employees scattered throughout the world. Approximately 39 percent, or about 5,700 UN employees are headquartered in New York City at UN Headquarters.

Although the UN Secretariat's regular budget staff is relatively static and fluctuates little from year to year, the UN's peacekeeping operations and extra budgetary workers are reflective of the world's current political environment. The size of the UN's peacekeeping staff is primarily dependent on the quantity and specific nature of the UN's current peacekeeping operations, as well as the level of civilian involvement within ongoing missions. Since the UN's inception in the mid 1940's, the UN's peacekeeping missions have greatly expanded and become more reliant on civilian staff (including UN extra budgetary staff). During the 1990 's, the number of peacekeeping missions increased by more than five times the number of peacekeeping missions in the 1980's and the size of UN headquarter's extra budgetary staff increased by approximately 400 employees to support ongoing peacekeeping operations (see Figure 4-3). Given the political and social climate in the world, this trend is expected to continue over the next two decades.

Assuming that the trend of the last decade will continue, staff levels can be expected to fluctuate by approximately 18 percent throughout the next decade, and average employment is estimated to increase by approximately four percent by 2010. Staff levels of the UN's extra budgetary workers at the UN Headquarters are best characterized as being cyclic. Although the UN's peacekeeping staff is dependent on current world events and the number and nature of ongoing missions, the size of the UN Headquarter's extra budgetary staff largely varies by approximately 1,000 workers within a ten year period, while the UN Headquarter's regular budget staff remains for the most part stable. It is expected that employment levels at UN Headquarters will continue to remain for the most part constant during the next ten to twenty years and fluctuate by approximately 1,000 workers per decade. Net employment, however, is estimated to increase by about four percent per decade, resulting in approximately 5,900 employees by 2010 and approximately 6,200 employees by 2020 . 


\section{B. The UN Programmes \& Funds in New York City}

Similarly to the UN Secretariat, the major UN programmes and funds headquartered in New York City are not expected to experience any major expansions, downsizing, or increases/decreases in current employment levels at the UN Headquarters. Currently, the United Nations International Children's Emergency Fund (UNICEF) and the United Nations Development Program (UNDP) have a combined total staff of approximately 2,000 people (including regular staff, consultants, and out-source [contract] personnel) in New York City.

Although the UNDP experienced a significant increase in staff levels within the last decade due to the creation of a subsidiary fund (the UNDP headquarters staff increased by approximately 50 percent during the late 1980's), the United Nations Development Fund for Women (UNIFEM), UNDP's headquarters staff is not expected to change significantly within the next 10-20 years. The UNDP largely operates as a decentralized organization through a unique network of field offices. Most of its services are delivered via local country and regional offices with 85 percent of the program's staff located at various local field offices across the globe. Currently, UNDP maintains operations in more than 150 countries, including 24 offices in Latin America and the Caribbean, 43 offices in Africa, 17 offices in the Middle East, 39 offices in Asia and the Pacific, and 24 offices in Europe and the Commonwealth of Independent States. UNDP projects are implemented in response to government requests and aim at aiding developing countries improve and efficiently use natural and human resources, as well as mobilize capital investments. It is predominately a hands-on, grass-roots level program. As mentioned within Task 3, UNDP currently occupies approximately 360,000 gsf of office space in Manhattan (160,000 gsf of office space in One UN Plaza; 180,000 gsf in 304 East $45^{\text {th }}$ Street; and 20,000 gsf in 336 East $45^{\text {th }}$ Street) and is expected to maintain an equivalent amount of office space through 2020. Approximately 55 percent (200,000 gsf) of this office space is commercially leased (owned by private entities).

UNICEF employment levels in New York City have for the most part remained constant throughout the last ten years. Although UNICEF experienced a significant increase (53\%) in staff levels during the late 1980 's, UNICEF does not anticipate any major growth at its headquarters in the next couple of decades. Like the UNDP, most of UNICEF's operations are carried out at the local and regional level. UNICEF maintains seven regional offices and more than 120 field offices in various countries throughout the world. It also administers programs within over 160 countries across the globe. UNICEF's work is predominately carried out via partnerships among local governments, various non-governmental organizations (NGO's), and local communities, where the UNICEF staff serve as educators, experts, advisors, and liaisons. In New York City, UNICEF currently occupies approximately 275,000 gsf of office space in Manhattan (180,000 gsf office space within $3 \mathrm{UN}$ Plaza and 95,000 gsf within 633 Third Avenue). More than 65 percent (approximately $180,000 \mathrm{gsf}$ ) of this office space is owned by UNDC, and less than 45 percent of (approximately $95,000 \mathrm{gsf}$ ) of this office space is commercially leased by UNICEF. Like UNDP, UNICEF is expected to maintain its existing office facilities through 2020.

Although UNDP and UNICEF will most likely expand their field operations and missions across the globe, both of these UN entities are not expected to experience any significant growth at their respective headquarter seats in New York City throughout the next two decades. They are expected to maintain their existing staff levels and continue to occupy the same amount of office space in 2010 and 2020. In total, UNDP and UNICEF are expected to occupy approximately 295,000 gsf of commercial (privately leased) office space and approximately $340,000 \mathrm{gsf}$ of UNDC office space. 


\section{The UN System's Patterns of Space Utilization}

As noted within Task 3, the UN System has almost always been in constant need of affordable and convenient high-quality office space, conference rooms, and meeting facilities. Since its inception in the mid-1940's, the UN System has grown significantly and its staff can no longer be contained within the 18acre, 1.3 million square feet (useable floor area) of the UN Headquarters campus. The UN's membership has more than tripled in size and its services, efforts, and peacekeeping operations have greatly expanded. The UN Headquarters campus and buildings, originally designed to accommodate up to 70 member states, are severely deteriorated and functioning well beyond their capacity. Although the UN Headquarters campus has undergone several physical modifications over the years, the UN Secretariat has been forced to seek and lease approximately 596,000 gsf of privately-owned (120,000 gsf) and/or UNDC-owned (476,000 gsf) office space in nearby facilities. The UN has also purchased the UNITAR building (located on the northwest corner of East $45^{\text {th }}$ Street and First Avenue), totaling approximately 22,600 square foot. In addition, almost all of the UN's specialized agencies and UN programmes and funds are located within additional facilities outside of the UN Headquarters. The entire UN System leases approximately 1.4 million sf of privately-owned (582,000 gsf) and/or UNDC-owned (819,000 gsf) office space in Midtown Manhattan (more than the total amount of useable floor area at UN Headquarters). Currently, there is no office space or conference/meeting facilities reserved for the UN's "Civil Society" (NGO's) at UN Headquarters.

After completing an extensive review of the physical needs of the UN Headquarters campus, the UN Secretary-General has proposed the implementation of a capital master plan, and it is under the consideration by the Member States. Although UN Headquarters is a superbly designed and wellconstructed landmark development, age and extended heavy usage have led to the degradation of the Secretariat Building and the conference/meeting facilities of the General Assembly and Conference Buildings. The UN's expanded membership, increased interaction with non-governmental organizations (NGO's) and the public, as well as technology advantages, have placed unprecedented burdens and new operations demands on the deteriorated headquarters complex. The UN campus is in dire need of major repairs, equipment replacements, and comprehensive refurbishing. Throughout the last fifty years, the UN buildings have never received fundamental upgrades to their security systems and operating systems (i.e mechanical and electrical systems). They are also no longer compliant with fire safety codes, environmental safety regulations, and handicap accessibility standards. They are also energy inefficient and contain some water-damage.

\section{United Nations Headquarters Capital Refurbishment}

During the $57^{\text {th }}$ Session of the UN General Assembly, which began September 2002, the UN SecretaryGeneral will propose a complete capital refurbishment project for the UN Headquarters campus, which the UN General Assembly will then decide a potential development plan. The proposed capital refurbishment plan, as currently contemplated, would substantially renovate the headquarters campus in a limited timeframe. The UN buildings would be installed with a full sprinkler system, a complete fire alarm system, and new heating, ventilation, and air conditioning systems. They would also be equipped with modern state-ofthe-art operating and security systems, and would conform to handicap accessibility standards. All asbestoscontaining material would be removed and any water-damaged material would be replaced. Technologic support spaces and data-distribution systems would be modernized and consolidated, and the conference/meeting facilities of the campus would be further upgraded with teleconferencing and video presentation equipment. In addition, the UN Headquarter's landscaping would also be improved. '

UN Gencral Asscmbly (6/28/00) Capital master plan: Report of the Secretary-General. 55th Scssion, Item 119: p. 11-3. 
Although the overall purpose of the UN capital master plan is to renovate and upgrade the headquarters campus, the proposed capital refurbishment has the potential to significantly expand the current capacity of the UN facilities without the construction of any new facilities or expansions to the existing buildings' envelopes. The proposed renovations would allow for more efficient use of existing space and would create more useable floor area from the existing floor area of the building envelopes. The proposed renovations would also include: the addition of three medium-sized meeting rooms (capacity 60 persons) in the first basement of the General Assembly Building; and provide for the construction of a centralized computer media center and broadcast area. ${ }^{2}$

The Secretary-General's current report offers two approaches to phasing the project. The First Approach would involve the construction of a swing space and consolidation building by the United Nations Development Corporation (UNDC) on the west side of Robert Moses playground, immediately south of the UN Headquarters campus, subject to appropriate state and local government approvals. The proposed building would be used temporarily for all meetings, as well as office space. However, in order to consider this Approach as a viable alternative, a suitable site for a comparable active recreational use replacement park for Robert Moses playground would have to be identified and set aside as public parkland. The City of New York and the UN have discussed the creation of a bicycle path and esplanade on the East River waterfront from East $41^{\text {st }}$ to East $48^{\text {th }}$ streets, as a possible means of mitigation. Under the First Approach, the proposed refurbishment work of the UN Headquarters campus would be completed in five years or less. After completion of the proposed refurbishment, the new building could potentially be used to consolidate many of the UN System's offices presently located in One UN Plaza and Two UN Plaza, as well as in various commercial premises, and the UN would have the option to purchase the new building. One and Two UN Plaza, as well as much of the UN System's current commercial office holdings would be vacated and be available for commercial rental in approximately 2010 .

The Second Approach would be a phased approach. The new meeting rooms in the basement of the General Assembly building would be created first, and serve as swing space for meetings. Swing space for office functions would be provided through a combination of short-term commercial leasing and the replacement of the two-story South Annex building with a 4-story building in the same location (on the UN Headquarters campus). In total, the UN would lease approximately $110,000 \mathrm{sf}$ of office space for the period of refurbishment. This approach would require six years or more to accomplish. After completion of the proposed refurbishment, the needed swing space would not be retained.

\section{Forecast of the UN System's Office Space Needs}

As the UN Secretariat's employment levels in New York City are cyclic and are expected to remain relatively stable and increase by less than eight percent ( 500 employees) over the next two decades, the total amount of office space occupied by the UN Secretariat is not expected to increase significantly by 2010 or 2020. Throughout the last several years, the UN Secretariat has maintained a zero nominal growth policy and has not expanded its office facilities. The UN Secretariat is expected to continue this zero-growth policy during the next twenty years and continue to occupy approximately 596,000 gsf of office space outside of the UN Secretariat building. Under the First Approach of the UN's capital refurbishment, UNDC would construct approximately $800,000 \mathrm{gsf}$ of swing space in the near future to accommodate the UN Secretariat's staff during the UN Headquarter's proposed refurbishment. ${ }^{3}$ Under the Second Approach, the

2 UN General Asscmbly (6/28/00) Capital master plan: Report of the Sectetary-General. 55th Session, Itcm 119: p. 13-15.

3 United Nations Facilitics Management Department, August 2001 
UN would lease approximately 110,000 gsf of office space swing space and construct 4-story building on the site of South Annex building (on UN Headquarters) to accommodate the UN Secretariat's staff during the UN Headquarter's proposed refurbishment.

Once the UN's capital refurbishment is complete, the UN Headquarters campus is expected to have ample available office space and conference facilities for the UN Secretariat's various departments by 2020 . The newly refurbished Secretariat Building will allow for the more efficient use of space and create more useable floor area for office space. Most of the UN Secretariat's minimal growth for the next two decades will be accommodated by the proposed renovations to the Secretariat Building. In addition, the UN will also have the option of retaining its swing space. Under the First Approach, the UN would only be expected to retain (i.e., continue to lease and ultimately purchase) its swing space if the UN were to vacate an equivalent amount of space in One and Two UN Plaza, as well as other commercial premises. This would allow One and Two UN Plaza to be available for commercial office rental in 2010.

The entire UN System within New York City is also not expected to grow significantly by 2020. As most of the UN's specialized agencies and UN programmes and funds are anticipated to maintain existing staff levels at the UN Headquarters seat, the UN System (including the UN Secretariat) is expected to continue to occupy approximately 1.4 million square feet of leased office space in Manhattan in CB6. More than 71 percent (approximately 1,000,000 gsf [800,000 gsf would be the proposed swing space]) of this leased space would be owned by UNDC and approximately 400,000 gsf would be commercially leased.

\section{II. PERMANENT MISSIONS EMPLOYMENT TRENDS AND SPACE UTILIZATION}

Currently, there are 191 member states of the UN, 187 of which have permanent representation (permanent missions) in the vicinity of UN Headquarters in Manhattan (see Table 4-2). Since the establishment of the UN in the mid-1940's, the number of UN member states and the number of permanent missions located in New York City has been steadily increasing. More than 130 nations have joined the UN since its inception in 1945, and approximately 99 percent of the UN's member states have established permanent mission offices in New York City.

\section{A. Member States Representation in New York City-1977-2000}

Throughout the last three decades, UN membership has increased significantly and the number of member states with commercial office space in New York City has greatly expanded (see Table 4-2). Since 1977, UN membership has increased by more than 28 percent (42 member states) and the New York City permanent mission community has grown by approximately 33 percent (47 permanent missions). Most of these newly established member states and permanent missions represent Caribbean and southeast Pacific island nations, as well as eastern European and Balkan countries.

Although the UN has for the most part experienced a gradual increase in membership since its inception in the mid-1940's, UN membership has grown substantially over the last 30 years. More than 20 percent of the its current member states joined during the late 1970's, 1980's, and 1990's, and approximately 25 percent of member states have established permanent missions in New York City since the late 1970's. One of the greatest increases in UN membership and in the influx of permanent mission offices in New York City was in the early 1990's, when approximately 26 nations joined the UN and 29 member states 
established permanent mission offices in New York City. This significant influx of member states can be attributed to the collapse of the former Soviet Union (USSR) and the fall of several communist regimes in eastern Europe (e.g. Yugoslavia and Czechoslavia). Over the last 25 years, UN membership has grown by approximately 1.25 percent per year. Since 1992, the rate of membership growth in the UN has declined significantly. Over the last 10 years, UN membership has only increased by an average rate of approximately 0.44 percent per year.

Table 4-2: Member Growth in the United Nations- 1977-2002

\begin{tabular}{|c|c|c|c|c|}
\hline Year & No. Member State & Percent Change & $\begin{array}{c}\text { Tot. No. of Permanent Missions } \\
\text { in Manhattan }\end{array}$ & Percent Change \\
\hline 1977 & 149 & $1.4 \%$ & 140 & $\mathrm{n} / \mathbf{a}$ \\
\hline 1981 & 157 & $5.4 \%$ & 148 & $5.7 \%$ \\
\hline 1990 & 159 & $1.2 \%$ & 154 & $4.1 \%$ \\
\hline 1994 & 185 & $16.3 \%$ & 183 & $18.8 \%$ \\
\hline 2000 & 189 & $2.2 \%$ & 186 & $1.6 \%$ \\
\hline 2002 & 191 & $1.1 \%$ & 187 & $<1.0 \%$ \\
\hline \multicolumn{2}{|c|}{ Percent Change (1977-2002) } & $28.1 \%$ & $\mathrm{n} / \mathrm{a}$ & $33.6 \%$ \\
\hline \multicolumn{5}{|c|}{ 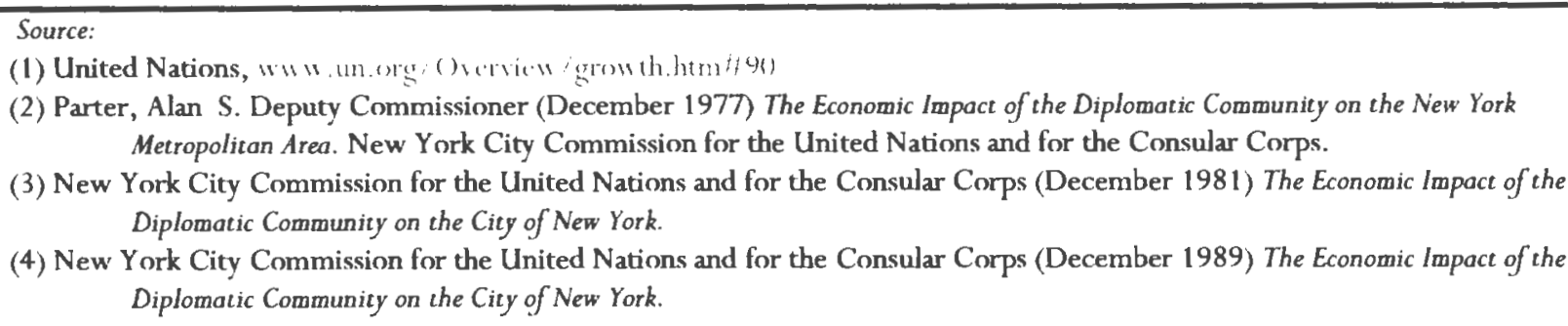 } \\
\hline
\end{tabular}

Projected Growth of Permanent Missions in New York City 2010 \& 2020

The future growth of permanent missions in New York City is difficult to predict with any great accuracy. Most of the current UN member states already maintain permanent mission offices in Manhattan, and most of the large independent nations of the world are already member states to the UN. Very few existing nations are not currently represented at the UN as member states or as observer missions or other entities. There are only four existing UN member states (approximately 1 percent) that do not have permanent representation (mission offices) near the UN Headquarters in Manhattan. In addition, there is only one remaining permanent observation mission and an observer entity that could potentially join the UN as member states.

Kiribati, Palau, and East Timor are the only three existing UN member states that do not have permanent representation at UN Headquarters in New York City, and Equatorial Guinea is the only UN member state that maintains a permanent mission outside of New York City in Mount Vernon, NY. Both Kiribati and Palau are small Pacific island nations with populations of less than 90,000 people and annual per capita incomes of less than $\$ 9,000$. They joined the UN in the mid to late-1990's and have not yet established permanent mission offices. However, it can be assumed that within the next 10 to 20 years, these two member states will most likely establish permanent mission offices near the UN in Manhattan. Given the 
small population of the two nations, both of these proposed mission offices would be expected to be small in size (less than 10,000 gsf) and possess minimum staff levels (less than 10 employees).

The provincial state of East Timor gained full independence on May 20, 2002 and joined the UN as a member state in October 2002. Most likely East Timor will establish a permanent mission office near the UN in Manhattan within the next 10 to 20 years. As East Timor has less than a million inhabitants and very low per capita incomes, East Timor's permanent mission office is also expected to be very small in size (less than $10,000 \mathrm{sf}$ ) with few staff members (less than 10 people).

The current mission office of Equatorial Guinea is located approximately 30 minutes north of the UN Headquarters just outside of New York City, in Westchester County. It can also be assumed that Equatorial Guinea will most likely decide to relocate its office facilities to Manhattan to be in closer proximity to the UN Headquarters seat and the other member states within the next 10-20 years. Equatorial Guinea's proposed Manhattan mission office would also be expected to be small in size and have a staff of approximately 10 people.

Although there is one permanent observer mission/nation (Holy See) and an observer entity (Palestine) to the UN that may elect to become UN member states in the future, these two observer entities currently maintain commercial office facilities to the UN in Manhattan, and would be expected to continue to occupy their existing facilities in the future.

It is difficult to predict which other nations or entities may join the UN and/or establish permanent mission offices at UN Headquarters due to the difficulty of predicting what political, social, or economic forces or occurrences could lead to the formation of new countries and/or the induction of new member states. It is also extremely difficult to determine how many additional nations may join the UN over the next couple of decades. Throughout the late 1970's and early 1980's, most of the UN's new member states were Caribbean island nations, southeast Asian nations, and a few African nations. During the early 1990's, the UN experienced one of it greatest increases in membership since its inception with the induction of numerous eastern European nations and Balkan countries. During the late 1990's, the UN continued to experience an influx of several southeast Asian nations. By the end of the 1990's, UN membership had expanded by 30 member states ( 19 percent).

Most likely, the UN will not experience the same rate or same type of growth in the next two decades, as it did during the early 1990's. The primary cause for the explosion in UN membership during the recent past was the collapse of the Soviet Union and the fall of other large communist nations. As there are few large nations in the world with unstable governments, the probability of a large nation dividing into smaller countries with independent governments is very low. Many of the remaining countries in the world that are not member states to the UN are small island nations in the southeast Pacific and in the Caribbean. Other areas or regions in the world that have the potential to become UN member states are recently independent nations or nations struggling to gain independence including, additional Balkan countries, the TransDneister Republic, Chechnya, Abkazia, Montenegro, Kurdistan, Kashmir, and others. Furthermore, civil strife in many regions of Africa could also lead to the formation of new independent nations.

While the number of UN member states will likely increase with the formation of new countries, the total number of permanent missions in New York City is not expected to increase significantly. Assuming that the UN will experience similar rates of growth over the next decade as it has over the past two and half decades, which is a very conservative assumption, UN membership can be expected to increase by approximately 3-8 percent by 2010, and approximately 6-16 percent by 2020 (see Table 4-3). Based on 
these conservative assumptions, approximately 5 to 15 new member states could be inducted into the UN by 2010 , and approximately 6 to 16 new member states between 2010 and 2020, for a total of 11 to 31 members by 2020. Almost all of these new member states are expected to establish permanent mission offices in New York City by 2020.

Table 4-3: Forecast of Member Growth in New York City

\begin{tabular}{cccc}
\hline Year & No. of New Members ' & Total No. of Members & Percent Change Per Decade \\
2000 & 30 & 189 & $19 \%$ \\
2010 & $5-15$ & $194-204$ & $3 \%-8 \%$ \\
2020 & $6-16$ & $200-220$ & $3 \%-8 \%$ \\
\hline
\end{tabular}

The projected rate of growth for new UN member states over the next 20 years is based on the historic trends of the past two decades. The projected number of new member states is an estimate that is derived from the rate of UN membership growth over the last 25 years $(1.25$ percent), as well as the last 10 years $(0.44$ percent).

\section{B. Employment within Permanent Missions}

Permanent missions in New York City are as diverse and unique as the individual countries they represent at the UN. They vary widely in size and in expenditures, with employment levels ranging from approximately 2 to 250 employees, and budgets ranging from less than 1.0 million to over 50.0 million dollars. The size of a particular permanent mission's office is largely dependent on and reflective of the operating budget of a mission office and the overall wealth of its representative nation. Most of the UN member states (approximately 86 percent) have permanent mission staffs of 5-40 employees. Very few missions have staffs with less than five employees, or staffs larger than 80 employees. Almost all of these employees are foreign residents and are natives of their respective countries.

Generally, permanent missions possess two types of employees, including general staff and diplomatic staff. The general or administrative staff of a permanent mission are the secretaries, bookkeepers, translators, advisors, and technical experts of a member state's mission. They represent the bulk of a mission's employment and vary greatly in number from mission to mission. Permanent missions with significant operating budgets typically have large administrative staffs, while missions with small operating budgets have smaller administrative staffs. The diplomatic staff of a permanent mission are a UN member state's ambassadors and other representative envoys, who are granted diplomatic immunity in the United States. They represent approximately $30-40$ percent of a permanent mission's staff.

Permanent Mission Employment and Staff Levels: 1977-1999

As the total number of permanent missions in New York City has been steadily increasing, the total number of people employed at permanent missions has also increased. Since the late 1970's, the total number of permanent mission employees (including foreign dignitaries) has increased by approximately 41 percent or 1,370 people, while the total number of permanent missions in New York City has increased by approximately 30 percent or 46 missions. Although the total number of permanent mission employees decreased by approximately nine percent in the late 1980's, employment levels for permanent missions went up during the early 1990's to surpass 1980 levels. As of May 1999, there were approximately 4,570 people employed at 186 permanent missions in Manhattan. On average, approximately 24 people were employed at a permanent mission office. 
Although the total number of people working for a permanent mission increased substantially over the last 25 years, almost all of the employment growth in permanent missions can be attributed to additional member states establishing offices at UN Headquarters. Most of the already established permanent missions in New York City experienced little growth, if any, between 1970 and 1999. Employment levels for individual permanent missions remained relatively stable. Since the late 1970 's, the employment levels of individual permanent missions have increased by less than seven percent, and the average number of employees per mission has fluctuated between 20 to 25 people (see Table 4-4). During the last 20 years, permanent mission employment has typically fluctuated by less than 500 people over a five year period.

\section{Forecast of Future Employment Trends for Permanent Missions 2010 \& 2020}

Like the UN Secretariat, the future employment level of permanent missions in New York City is difficult to predict. As the employment of permanent missions is highly dependent on the future membership and growth of the UN and the wealth of member states, the future status of permanent mission employment in New York City is ultimately dependent on the world's political environment. Throughout the 1990's, most of the employment growth of permanent missions was attributed to the significant increase in UN membership and the total number of countries establishing new permanent mission offices in New York City. Assuming that the trend of the 1990's and 1980's will continue, the existing staff levels of the current permanent missions are expected to remain relatively stable and increase little from year to year. Most of the current member states with permanent mission offices in New York City are expected to maintain their existing staff levels, or increase existing levels by approximately 7 percent. The average staff size of a permanent mission is also expected to remain between 20-25 people. As mentioned above, if UN membership continues to grow at existing levels, approximately 5 to 15 new member states could be inducted into the UN by 2010 , and approximately 6 to 16 additional member states between 2010 and 2020, for a total of 11 to 31 members by 2020. Most of these new UN member states are expected to be small in size and possess relatively few employees, less than the current average of 24 persons per mission.

\section{Table 4-4: Permanent Missions' Employment Growth in New York City}

\begin{tabular}{|c|c|c|c|c|c|}
\hline Year & $\begin{array}{l}\text { No. of Permanent } \\
\text { Missions in Manhattan }\end{array}$ & $\begin{array}{l}\text { Percent } \\
\text { Change }\end{array}$ & $\begin{array}{l}\text { Tot. No, of } \\
\text { Employees }\end{array}$ & $\begin{array}{l}\text { Percent Change } \\
\text { in Employees }\end{array}$ & $\begin{array}{l}\text { Avg. No. of } \\
\text { Employees/Mission }\end{array}$ \\
\hline 1977 & 140 & $\mathrm{n} / \mathrm{a}$ & 3,200 & $\underline{n / a}$ & 22.8 \\
\hline 1980 & 148 & $5.7 \%$ & 3,300 & $3.1 \%$ & 22.3 \\
\hline 1988 & 154 & $4.0 \%$ & 3,000 & $-9.1 \%$ & 19.5 \\
\hline 1994 & 183 & $18.8 \%$ & 3,800 & $26.7 \%$ & 20.8 \\
\hline 1999 & 186 & $1.6 \%$ & 4,570 & $20.3 \%$ & 24.5 \\
\hline $\mathrm{Net} C$ & Change (1977-1999) & $30.1 \%$ & 1,370 & $41.0 \%$ & 1.7 \\
\hline \multicolumn{6}{|c|}{$\begin{array}{l}\text { (1) Parter, Alan S. Deputy Commissioner (December 1977) The Economic Impact of the Diplomatic Community on the New York } \\
\text { Metropolitan Area. New York City Commission for the United Nations and for the Consular Corps. }\end{array}$} \\
\hline \multicolumn{6}{|c|}{$\begin{array}{l}\text { (2) New York City Commission for the United Nations and for the Consular Corps (December 1981) The Economic Impact of the } \\
\text { Diplomatic Community on the City of New York. } \\
\text { (3) New York City Commission for the United Nations and for the Consular Corps (December 1989) The Economic Impact of the }\end{array}$} \\
\hline
\end{tabular}


Although the total amount of employment for permanent missions has increased by approximately 43 percent $(1,370$ workers) over the past thirty years, the future employment level of permanent missions in New York City is not expected to increase to such a degree during the next 10 to 20 years. The four UN member states that do not currently have permanent representation in New York City would be expected to add less than 40 employees to the permanent mission workforce, and the new member state of Switzerland and the observer entities of Holy See and Palestine already maintain mission offices to the UN and would be expected to maintain their existing staff levels. While the number of permanent missions may increase with the induction of additional small island nations in the southeast Pacific and in the Caribbean, and with the formation and independence of new countries, the total number of permanent mission employees will not increase substantially. Most potentially new member states would not be financially well-off and very small in size. As a result, these nations would likely have few employees at their respective mission in New York City. The employment level of existing permanent missions is likely to remain relatively stable or exhibit a slight increase, as it has for the last 20 years. It is expected that the employment levels for permanent missions would increase by approximately 350 employees in 2010, and by approximately 400 employees between 2010 and 2020. Net employment for permanent missions is expected to be approximately 4,900 employees in 2010 and 5,300 employees in 2020 .

\section{Permanent Missions Patterns of Space Utilization}

As noted previously, permanent missions range in size from less than 1,000 gsf to more than 200,000 gsf. Although most permanent missions would prefer to occupy the highest quality, spacious office facilities in the closest proximity to the UN Headquarters, permanent missions occupy a wide variety of office space including, high-quality Class A facilities, commercial condominium space, affordable Class B facilities, residential apartment space, and converted-loft Class $\mathrm{C}$ office space. They are also scattered mostly throughout much of Midtown Manhattan, but a few missions are located within Downtown, Midtown South, and along the Upper East Side. Currently, approximately 53 percent of permanent missions occupy high-quality Class A office facilities. However, many permanent missions will sacrifice the quality of office space to locate near the UN.

\section{Permanent Missions' Space Utilization-1980-2000}

Throughout the last twenty years, permanent missions have predominately concentrated near or adjacent to the UN Headquarters complex in Manhattan Community Boards Six and Eight (CB6 and CB8). As shown in Table 4-5, the few missions that were located farthest from the UN in Community Boards 7 and 9, during the early 1980's, have since moved to either CB6 or CB8 along the east side of Midtown Manhattan during the 1990's. More than 70 percent of permanent mission offices have been located in CB6, and approximately 15 to 20 percent of permanent mission offices have been located in CB8, since the early 1980 's. Most of the newly established member states to the UN have also elected to locate their mission offices in CB6. Since the 1980's, the total number of permanent missions in CB6 has grown by approximately 33 percent ( 39 permanent missions) and total number of permanent missions in CB8 has decreased by approximately 13 percent ( 3 permanent missions). Approximately 510,000 square feet of office space in CB6 has been converted into permanent mission space since 1980. 
Table 4-5: Permanent Missions to the UN Referenced by Community Board-1980-2001

\begin{tabular}{|c|c|c|c|c|c|c|}
\hline \multirow{2}{*}{$\begin{array}{l}\text { Manhattan } \\
\text { Community } \\
\text { Board }\end{array}$} & \multicolumn{2}{|c|}{1980} & \multicolumn{2}{|c|}{1988} & \multicolumn{2}{|c|}{2001} \\
\hline & $\begin{array}{c}\underline{S E} \\
\text { Occupied }^{1}\end{array}$ & $\frac{\text { Percent of }}{\text { Total }}$ & $\begin{array}{c}\underline{S F} \\
\text { Occupied }^{t}\end{array}$ & $\frac{\text { Percent of }}{\text { Total }}$ & $\begin{array}{c}\text { SF } \\
\text { Occupied }^{I^{\prime}}\end{array}$ & $\frac{\text { Percent of }}{\text { Total }}$ \\
\hline CB6 & $1,100,000$ & $73 \%$ & $1,150,000$ & $71 \%$ & $1,610,000$ & $80 \%$ \\
\hline$C B 5$ & 100,000 & $7 \%$ & 110,000 & $7 \%$ & 100,000 & $5 \%$ \\
\hline$C B 7$ & 10,000 & $<1 \%$ & 10,000 & $<1 \%$ & 0 & $\mathrm{n} / \mathrm{a}$ \\
\hline$C B 8$ & 300,000 & $20 \%$ & 340,000 & $21 \%$ & 300,000 & $15 \%$ \\
\hline$C B 9$ & $\underline{0}$ & $\underline{n} / \mathbf{a}$ & 10,000 & $\leq 1 \%$ & $\underline{0}$ & $\underline{n} / \mathbf{a}$ \\
\hline Total & $1,510,000$ & $100 \%$ & $1,620,000$ & $100 \%$ & $2,010,000$ & $100 \%$ \\
\hline
\end{tabular}

Estimate of total square feet of commercial space occupied by the 148 missions is extrapolated from data collected on 66 permanent missions in New York City.

2 Estimate of total square feet of commercial space occupied by the 154 missions is extrapolated from data collected on 91 permanent missions in New York City.

3 Estimate of total square feet of commercial space occupied by the 187 missions is extrapolated from data collected on 166 permanent missions in New York City.

The majority of permanent missions that are located in CB6 have predominately concentrated in the residential neighborhood of Turtle Bay (see Table 4-6). However, the residential neighborhoods of Murray Hill, Tudor City, and Beekman Place have experienced a slight increase in the total amount of permanent missions since the early 1980's. During the last two decades, the residential neighborhood of Beekman Place experienced a 7 percent increase in the total amount of office space occupied by permanent missions, while the neighborhood of Turtle Bay lost approximately 12 percent of its mission office space. Approximately 56 percent of (86) permanent mission offices in CB6 are located within Turtle Bay, and approximately 16 to 19 percent of (25 and 30) permanent missions are located within Murray Hill and Tudor City, respectively.

The total amount of office space occupied by permanent missions has increased by approximately 500,000 gsf (33 percent) since 1980 . Although only 28 percent of permanent missions have remained within the same office facilities since 1988 and some of the larger UN member states have constructed or purchased new mission space, most permanent missions have experienced very little growth since the 1980's. The majority of permanent missions have not expanded significantly and occupy relatively the same amount of space as they did in the early 1980 's. The typical or average size of a permanent mission has fluctuated little and has remained at approximately 10,800 gsf (450 sf per employee). The average sizes of typical missions owned or leased by a foreign government have also remained relatively constant $(9,000$ gsf for a leased permanent mission, 14,000 gsf for a permanent mission owned by a foreign government). Most of the increase in permanent mission office space during the last 25 years was as a result of additional and new UN member states establishing missions in New York City. 


\section{Table 4-6: Permanent Missions to the UN in Community Board 6 Referenced by Neighborhood- 1980-2001}

\begin{tabular}{|c|c|c|c|c|c|c|}
\hline \multirow[t]{2}{*}{ Neighborhood } & \multicolumn{2}{|c|}{1980} & \multicolumn{2}{|c|}{1988} & \multicolumn{2}{|c|}{2001} \\
\hline & $\begin{array}{c}\text { SF } \\
\text { Occupied }^{\prime}\end{array}$ & $\begin{array}{c}\text { Percent of } \\
\text { Total }\end{array}$ & $\begin{array}{c}\text { SF } \\
\text { Occupied }^{I}\end{array}$ & $\begin{array}{c}\text { Percent of } \\
\text { Total }\end{array}$ & $\begin{array}{c}\underline{S F} \\
\text { Occupied }^{l}\end{array}$ & $\begin{array}{c}\text { Percent of } \\
\text { Total }\end{array}$ \\
\hline Turtle Bay & 740,000 & $67 \%$ & 690,000 & $60 \%$ & 880,000 & $55 \%$ \\
\hline Sutton Place & 0 & $\mathrm{n} / \mathrm{a}$ & 0 & $\mathrm{n} / \mathrm{a}$ & 10,000 & $<1 \%$ \\
\hline Murray Hill & 190,000 & $17 \%$ & 190,000 & $17 \%$ & 280,000 & $17 \%$ \\
\hline Kips Bay & 20,000 & $2 \%$ & 50,000 & $4 \%$ & 50,000 & $3 \%$ \\
\hline Tudor City & 140,000 & $13 \%$ & 210,000 & $18 \%$ & 280,000 & $17 \%$ \\
\hline Beekman & 10,000 & $\leq 1 \%$ & 10,000 & $\leq 1 \%$ & $\underline{110,000}$ & $\underline{7 \%}$ \\
\hline Total & $1,100,000$ & $100 \%$ & $1,150,000$ & $100 \%$ & $1,610,000$ & $100 \%$ \\
\hline
\end{tabular}

Estimate of total square feet of commercial space occupied by the 148 missions is extrapolated from data collected on 66 permanent missions in New York City.

2 Estimate of total square feet of commercial space occupied by the 154 missions is extrapolated from data collected on 91 permanent missions in New York City.

Estimate of total square feet of commercial space sccupied by the 187 missions is extrapolated from data collected on 166 permanent missions in New York City.

There has also been an increase in the number of UN member states that own their respective commercial office facilities since the early 1980 's. Approximately 37 percent of all permanent missions currently own their respective office facilities. As shown in Table 4-7, there has been an 13 percent increase in the amount of mission office facilities owned by a foreign government since 1980. Although some of the larger permanent missions (e.g. Nigeria, Turkey, Germany, Indonesia, and the Philippines) constructed or purchased new expanded office facilities in the recent past, the majority of commercial office space purchased by permanent missions during the 1980's and 1990's was relatively small in size (less than 10,000 sf.) and was commercial condominium space in buildings surrounding the UN Headquarters.

Table 4-7: Percentage of Permanent Mission Space Owned or Leased by a UN Member State

\begin{tabular}{ccc}
\hline Year & Percentage of Space Leased & Percentage of Space Owned \\
1980 & $76 \%$ & $24 \%$ \\
1988 & $69 \%$ & $31 \%$ \\
1999 & $63 \%$ & $37 \%$ \\
\hline
\end{tabular}


As the majority of permanent missions have predominately located near the UN Headquarters campus, most permanent missions are concentrated within the four office submarkets closest to the UN Headquarters in Midtown Manhattan (see Table 4-8). Since the 1980's, the majority of permanent missions have located within the UN Plaza, Grand Central, Plaza, and the Upper East Side office submarkets. Throughout the 1980's and 1990's, more than 380,000 gsf of office space in the UN Plaza submarket and approximately 140,000 gsf of office space in the Plaza submarket have been converted into permanent mission office space. As of December 2001, approximately 51 percent (94) of permanent missions were located within the UN Plaza office submarket. Most new UN member states have also established mission facilities within the UN Plaza submarket, with a few locating missions in the Plaza and Murray Hill submarkets. Since the 1980's, the UN Plaza submarket has experienced an influx of approximately 35 permanent missions.

Table 4-8: Permanent Missions to the UN Referenced by Manhattan Office Markets- 1980-2001

\begin{tabular}{|c|c|c|c|c|c|c|}
\hline \multirow{2}{*}{$\begin{array}{l}\text { Office } \\
\text { Submarket }\end{array}$} & \multicolumn{2}{|c|}{1988} & \multicolumn{2}{|c|}{1980} & \multicolumn{2}{|c|}{2001} \\
\hline & $\begin{array}{c}\underline{S F} \\
\text { Occupied }^{1}\end{array}$ & $\frac{\text { Percent of }}{\text { Total }}$ & $\underset{\text { Occupied }^{2}}{S E}$ & $\frac{\text { Percent of }}{\text { Total }}$ & $\begin{array}{c}S E \\
\text { Occupied }^{3}\end{array}$ & $\frac{\text { Percent of }}{\text { Total }}$ \\
\hline UN Plaza & 550,000 & $37 \%$ & 650,000 & $40 \%$ & 930,000 & $46 \%$ \\
\hline Plaza & 170,000 & $11 \%$ & 200,000 & $12 \%$ & 310,000 & $15 \%$ \\
\hline Grand Central & 430,000 & $29 \%$ & 350,000 & $22 \%$ & 390,000 & $19 \%$ \\
\hline Upper E. Side & 260,000 & $17 \%$ & 290,000 & $18 \%$ & 260,000 & $13 \%$ \\
\hline Murray Hill & 60,000 & $4 \%$ & 90,000 & $6 \%$ & 110,000 & $6 \%$ \\
\hline Gramercy Park & 20,000 & $1 \%$ & 20,000 & $1 \%$ & 10,000 & $<1 \%$ \\
\hline Midtown North & 10,000 & $<1 \%$ & 0 & $\mathrm{n} / \mathrm{a}$ & 0 & $\mathrm{n} / \mathrm{a}$ \\
\hline Upper W. Side & 10.000 & $\leq 1 \%$ & $\underline{20.000}$ & $1 \%$ & $\underline{0}$ & $\underline{\mathrm{n} / \mathrm{a}}$ \\
\hline Total & $1,510,000$ & $100 \%$ & $1,620,000$ & $100 \%$ & $2,010,000$ & $100 \%$ \\
\hline
\end{tabular}

Estimate of total square feet of commercial space occupied by the 148 missions is extrapolated from data collected on 66 permanent missions in New York City.

2 Estimate of total square feet of commercial space occupied by the 154 missions is extrapolated from data collected on 91 permanent missions in New York City.

Estimate of total square feet of commercial space occupied by the 187 missions is extrapolated from data collected on 166 permanent missions in New York City.

As more than 90 percent of office space in the UN Plaza, Grand Central, and the Plaza office submarkets is Class A, the majority of permanent missions have also occupied high-quality Class A office space throughout much of the 1990's. Approximately 53 percent (97) of permanent missions were located within Class A office facilities in the late 1990's. Less than 16 percent (30) of permanent missions were located in Class B office facilities and less than 7 percent (13) of were located within Class C facilities. The remaining 25 percent (46) of permanent missions were located within unclassified office facilities or commercial condominium space. 
Forecast of Future Space Utilization Patterns for Permanent Missions: 2010 \& 2020

Assuming that the utilization trends of permanent missions during the last twenty years will continue through the next two decades, the vast majority of the existing and projected UN member states are expected to occupy mission facilities in close proximity to the UN in CB6, and in the office submarkets of UN Plaza, Plaza, Grand Central, and Murray Hill. The total amount of office space occupied by permanent missions in New York City is not expected to increase significantly and permanent missions are not expected to have substantial additional office space needs in the next 20 years. Although it is almost impossible to determine the exact office space needs of individual missions, as they vary considerably in size, staff levels, and expenditures, the size of a typical or average permanent mission is expected to remain at approximately 10,800 gsf (approximately $450 \mathrm{gsf}$ per employee). Most of the current permanent missions are expected to occupy the same amount of space and will experience very little growth within the next couple of decades. Many of the current permanent missions are also expected to continue to occupy the same office facilities. As the majority of projected permanent missions are anticipated to be small nations with relatively low per capita incomes, the majority of projected missions are expected to privatelylease small office facilities (significantly less than 10,000 gsf) in the immediate vicinity of the UN.

If existing trends continue UN membership can be expected to increase by approximately 3-8 percent by 2010, and approximately 6-16 percent by 2020 . Approximately 5 to 15 new member states could be inducted into the UN by 2010, and approximately 11 to 31 new member states by 2020. Almost all of these new member states would establish some type of permanent mission office in Manhattan. In total, the amount of office space occupied by permanent missions in Manhattan is expected to increase by approximately 2 to 6 percent (40,000 gsf to 130,000 gsf) by 2010 and by approximately 5 to 14 percent ( 90,000 gsf to $280,000 \mathrm{gsf}$ ) by 2020 (see Table 4-9). Based on an expected increase of up to 130,000 square feet by 2010 and by 280,000 square feet by 2020, the maximum amount of office space occupied by permanent missions in Manhattan is expected to be approximately 2.14 million square feet in 2010 , and 2.29 million square feet in 2020 .

Table 4-9: Projected Square Feet of New Mission Space in Manhattan

\begin{tabular}{lccc}
\hline Year & No. of New Missions & Tot. SF Occupied by New Missions & Total SF Occupied by all Missions \\
\hline 2000 to 2010 & 5 to 15 & 40,000 to 130,000 sf & $2,050,000$ to $2,140,000$ sf \\
2010 to 2020 & 6 to 16 & 60,000 to 150,000 sf & $2,110,000$ to $2,290,000$ sf \\
\hline
\end{tabular}

Total square feet occupied by new permanent missions in Manhattan is based on the average size of a typical mission leased by a foreign government.

Almost all of the permanent missions currently located within the immediate vicinity of the UN in CB6, are expected to maintain their existing office facilities or relocate to similar facilities within the surrounding area. Most of the projected permanent missions are also expected to establish missions near the UN Headquarters in CB6. By 2020, if existing growth rates and utilization patterns continue, CB6 will experience a 7 to 20 percent increase in the total number of UN member states maintaining mission offices in their community board. In 2020, approximately 84 to 86 percent of (a maximum of 189) permanent missions in New York City will be located within CB6, and less than 20 percent of permanent missions will be located within either CB5 or CB8 (see Table 4-10). Over the next 20 years, permanent mission office space in CB8 and CB5 is expected to be maintained and up to 280,000 gsf of office space in CB6 would be 
converted into permanent mission space. Approximately 2.1 to 2.3 million gross square feet of office space in CB6 is expected to be occupied by approximately 165 to 189 permanent missions in 2020 .

Table 4-10:

Permanent Mission Office Space Referenced by Community Board in 2010 \& 2020

\begin{tabular}{l|c|c|c|c}
\hline \multirow{2}{*}{ Community } & \multicolumn{4}{|c}{2010} \\
\cline { 2 - 5 } Board & SFOccupied & Growth in SF & Percent of Tot. & Tot. Percent Change from 2001 \\
\hline CB6 & $1,650,000$ to $1,740,000$ & 40,000 to 130,000 & $81 \%$ & $1 \%$ \\
CB8 & 300,000 & 0 & $14 \%$ & $-1 \%$ \\
CB5 & 100,000 & $\underline{0}$ & $\underline{5 \%}$ & $0 \%$ \\
Total & $2,050,000$ to $2,140,000$ & 40,000 to 130,000 & $100 \%$ & \\
\hline
\end{tabular}

Estimate of total square feet of commercial space nccupied is based on 5 to 15 additional UN member states establishing permanent mission offices in Manhattan (for total of 194 to 204 missions) and the average size of a typical mission owned by a foreign governmental being approximately 14,000 gsf and the average size of a typical mission leased by a foreign government being approximately $9,000 \mathrm{gsf}$. Almost all of the new permanent missions in Manhattan are anticipated to be leased office space.

\begin{tabular}{|c|c|c|c|c|}
\hline \multirow{2}{*}{$\begin{array}{l}\text { Community } \\
\text { Board }\end{array}$} & \multicolumn{4}{|c|}{2020} \\
\hline & SFOccupied & Growth in SF & Percent of Tot. & Tot. Percent Change from 2001 \\
\hline CB6 & $1,710,000$ to $1,890,000$ & 100,000 to 280,000 & $82 \%$ & $2 \%$ \\
\hline CB8 & 300,000 & 0 & $14 \%$ & $-1 \%$ \\
\hline CB5 & $\underline{100,000}$ & $\underline{0}$ & $4 \%$ & $-1 \%$ \\
\hline Total & $2,110,000$ to $2,290,000$ & 100,000 to 280,000 & $100 \%$ & \\
\hline & $\begin{array}{l}\text { of total square feet of } \\
\text { ing permanent mission o } \\
\text { owned by a foreign gov } \\
\text { y a foreign government b } \\
\text { ipated to be leased office }\end{array}$ & $\begin{array}{l}\text { mmercial space } \\
\text { es in Manhattan (fo } \\
\text { mental being appr } \\
\text { approximately } 9, \\
\text { ce. }\end{array}$ & $\begin{array}{l}\text { ed is based on } \\
\text { of } 200 \text { to } 220 \\
\text { tely } 14,000 \mathrm{gst} \\
\text { f. Almost all of }\end{array}$ & $\begin{array}{l}31 \text { additional UN member states } \\
\text { ns) and the average size of a typical } \\
\text { ne average size of a typical mission } \\
\text { w permanent missions in Manhattan }\end{array}$ \\
\hline
\end{tabular}

The majority of permanent missions in CB6 are expected to occupy leased commercial office facilities within Turtle Bay in 2010 and 2020. Almost all of the permanent missions currently located within Turtle Bay are expected to maintain their existing facilities in the Turtle Bay neighborhood and most of the new UN member states are expected to locate their mission facilities in Turtle Bay. If current trends continue, a small percentage of permanent missions will also continue to locate within the predominately residential neighborhoods of Murray Hill, Beekman Place, and Tudor City.

UN member states are also expected to continue to purchase commercial office facilities near the UN Headquarters campus to serve as permanent mission space. If permanent missions continue to follow the same tenure trends over the next two decades as they did during the 1980's and 1990's, approximately 38 percent of permanent missions will own their respective office facilities (a maximum of 83 missions) by 2020. Although the majority of permanent missions (62 percent) will continue to occupy leased office facilities, some of the smaller permanent missions are expected to purchase commercial condominium space 
in buildings surrounding the UN to serve as mission space. In total, the number of permanent missions owned by a foreign government is expected to increase by approximately 5 percent.

If existing office space utilization patterns continue, the majority of permanent missions in 2010 and 2020 are expected to continue to locate near the UN Headquarters campus within the office submarkets of UN Plaza, Plaza, Grand Central, and Murray Hill. Almost all of the permanent missions (154) located within the UN Plaza submarket are expected to maintain their existing facilities. As the majority of permanent missions prefer to locate in the closest proximity to the UN Headquarters campus, there is expected to be a high demand for commercial office space in the UN Plaza office submarket.

\section{FOREIGN CONSULATE EMPLOYMENT TRENDS AND SPACE UTILIZATION}

Foreign consular offices represent their respective state in a host country, and are not connected to the UN. Originally developed to promote and secure international trade between two countries, consular offices have evolved to encourage and protect trade, tourism, and investment between a host country and native country. Currently, Manhattan hosts the largest consular community in the world, and is home to 99 foreign consulates (100 consulates within New York City).

\section{A. Consulate Representation in New York City- 1980-2001}

New York City's consular community has been in existence for over 200 years. It is the oldest consular community within the United States and one of the largest in the world. Consular offices for France, Spain, the United Kingdom, and the Netherlands were some of the first foreign consulates established in the US during the late 1700 's. By the beginning of the twentieth century, most of the US's major trading partners had established consular offices in Manhattan.

As shown in Table 4-11, since the late 1970's the Manhattan consular community has grown by approximately nine percent (eight consular offices). Although Manhattan's consular community experienced a slight decline in the late 1980's, when several African and Middle Eastern nations closed their consular offices, the Manhattan consular community is slowly expanding again (see Table 4-12).

Table 4-11: Growth in Foreign Consulates in Manhattan- 1977-2001

\begin{tabular}{lcc}
\hline Year & No. of Consulates in Manhattan & Percent Change \\
1977 & 91 & $\mathrm{n} / \mathrm{a}$ \\
1981 & 93 & $2.2 \%$ \\
1989 & 87 & $-6.4 \%$ \\
1994 & 92 & $5.7 \%$ \\
2001 & 99 & $7.6 \%$ \\
Percent Change (1977-2001) & $8.8 \%$ \\
\hline Source: Register of Foreign Consulates \& Assoc. Govermment Offices in NY(2001,1989, \& 1980$) \&$ \\
\multicolumn{3}{c}{ The Economic Impact of the Diplomatic Community on NY $1989,1981, \& / 977}$.
\end{tabular}




\section{Table 4-12: Consular Uses that Left New York City During the 1980's}

\begin{tabular}{ccl}
\hline Years & Total Number & $\begin{array}{l}\text { Foreign Consulates that Left NYC } \\
\text { Afghanistan, Ethiopia, Gambia Republic, Iran, Jordan, } \\
\text { Kuwait, Niger, Oman, Sierra Leone, Somalia, Suriname }\end{array}$ \\
$1989-1989$ & 11 & $\begin{array}{l}\text { Fiji, Kenya, Madagascar, Sudan, Zaire } \\
\text { St. Vincent \& the Grenadines }\end{array}$ \\
\hline Source: Register of Foreign Consulates \&Assoc. Government Offices in NY (2001, 1989, \& 1980)
\end{tabular}

Throughout the 1990's, the Manhattan consular community experienced a significant influx of southeast Asian countries including Singapore, Thailand, Malaysia, and China, and an increase in southeast Pacific island nations including, St. Lucia. After the collapse of the Soviet Union and the fall of many communist regimes in eastern European nations, many of the newly formed Balkan nations and eastern European countries, such as Uzbekistan, Romania, Bulgaria, the Ukraine, Russia, the Kyrgyz Republic, Slovenia, Bosnia and Herzegovina, and Belarus also established consular offices in Manhattan. Since 1989, the rate of consular growth has more than doubled. Over the last thirteen years, the Manhattan consulate community has expanded by approximately 1 percent per year.

\section{Projected Growth of Foreign Consulates in Manhattan 2010 \& 2020}

Like permanent missions, the future growth of consular offices in Manhattan is also difficult to predict with any great accuracy. Most likely, the addition of new consular offices in Manhattan will depend on US foreign trade, tourism, and investment interests. New York City is a world city that is home to numerous foreign companies, banks, and other various international offices. It is also home to many of the US's major financial markets, important service industries, banks, investing firms and other brokerage houses. Although many of the US's major foreign trading and investment partners already maintain consular offices in New York City or in the Washington D.C. area with jurisdictional coverage in New York City, the New York City consulate community has the potential to expand significantly in the future. Global trade is growing. The current international trade levels of the world are approximately twenty-two times the levels of trade in 1950. Only 99 of the 189 UN current member states have consular offices in Manhattan. There is also one existing consulate (San Marino) in New York State that does not maintain its consulate office in Manhattan. In addition, many of the seventeen foreign consulates that were closed during the 1980's have the potential of reestablishing their consular offices in the next couple of decades.

Most of the existing consular offices in Manhattan represent European Nations, Caribbean island nations, Asian countries, southeast Pacific nations, South and Central American countries, and a few African Nations. Many Middle Eastern nations and most African nations do not currently maintain consulate offices in New York City. In addition to the possible reestablishment of several Middle Eastern and African consulates closed during the 1980's, there is a strong likelihood that some of the other existing UN member states may establish consular offices in New York City in the next two decades. However, it is difficult to predict which particular nations or entities may establish consular offices in Manhattan due to the difficulty of predicting what political, social, or economic forces or occurrences will drive international financial markets, trading, and tourism.

Assuming that the New York City consulate community will experience similar rates of growth over the next twenty years as it has in the 1989-2002 period, the New York City consulate community can be 
expected to increase by approximately 10 percent by 2010 and approximately 20 percent by 2020 . Approximately 10 new consular offices could locate within New York City by 2010, and approximately 10 additional consular offices between 2010 and 2020, for a total of 20 consular offices by 2020 (see Table 4$13)$.

Table 4-13: Forecast of Consular Growth in New York City

\begin{tabular}{lcccc}
\hline Year & No. of New Consulates per Decade & Total No. of Consulates & Percent Change Per Decade \\
2001 & 7 & 109 & $8 \%$ \\
2010 & 10 & 119 & $10 \%$ \\
2020 & 10 & $10 \%$ \\
\hline \multicolumn{5}{l}{ The projected rate of growth for new foreign consulates over the next 20 years is based on the historic trends of the } \\
growth from 1989-2000 (about 1 percent per year).
\end{tabular}

\section{B. Employment within Foreign Consulates}

Like permanent missions, foreign consular offices are extremely diverse. They range in size, scale and budget, and possess staffs of 2 to 250 people. They also have two classifications of workers, including a diplomatic staff and a general administrative staff. The general administrative staff makes up the bulk of employment and represents approximately 60 to 70 percent of the overall staff at a consular office while the diplomatic community usually represents less than 40 percent.

\section{Foreign Consulate Employment and Staff Levels: 1980-2001}

As the number of consular offices in Manhattan increased by approximately nine percent since 1980, the total number of employees working at foreign consulates also increased. Since the late 1970's, the total number of foreign consulate employees (including foreign dignitaries) increased by approximately 53 percent or approximately 1,080 people, while the total number of foreign consulates increased by approximately nine percent or nine foreign consulates (see Table 4-14). Although the total number of consular employees decreased by approximately 24 percent in the mid to late 1980 's, employment levels for foreign consulates increased during the early 1990's to 1981 employment levels. In general, the New York City consulate community has grown by approximately 25 percent every 5 to 8 years. As of May 1999, there were approximately 3,100 people employed at 99 foreign consular offices in Manhattan. On average, approximately 31 people were employed at a foreign consulate office.

Although the total number of people working for a foreign consulate has increased significantly over the last 25 years, most of this employment growth in foreign consular offices can be attributed to additional foreign nations establishing new offices in Manhattan. Most of the established foreign consulates experienced very little growth, if any, between 1970 and 1999. The average employment levels at consular offices did increase by approximately 40 percent ( 10 people) from 1977 to 2000 but, this can be attributed to the influx of 17 foreign consular offices. Most these consular uses represented eastern European and Balkan countries, south east Asian nations, and Caribbean island nations. During the last 20 years, foreign consulate employment has typically fluctuated by less than 600 people over a five year period. 
Forecast of Future Employment Trends for Foreign Consulates 2010 \& 2020

Like the UN Secretariat and permanent missions, the future employment level of foreign consulates is difficult to predict. As the employment of foreign consular offices is highly dependent on the world economy, US foreign trade, tourism, and investment interests, and the wealth of future foreign consulates, the future status of foreign consulate employment in New York City is ultimately dependent of the world's political environment and financial market. Assuming that the trend of the 1990's and the 1980's will continue, the existing staff levels of the current foreign consulates are expected to remain relatively stable and increase little from year to year. Most of the current foreign consular offices in New York City are expected to maintain their existing staff levels, however, some consular offices may experience increased staff levels over the next two decades. If existing employment trends continue, the average staff size of a typical foreign consulate is expected to increase to about 34 people for the forecast period.

Table 4-14: Foreign Consulate's Employment Growth in Manhattan

\begin{tabular}{lccccc}
\hline Year & $\begin{array}{c}\text { No. of Consulates } \\
\text { in Manhattan }\end{array}$ & $\begin{array}{c}\text { Percent } \\
\text { Change }\end{array}$ & $\begin{array}{c}\text { Tot. No, of } \\
\text { Employees }\end{array}$ & $\begin{array}{c}\text { Percent } \\
\text { Change }\end{array}$ & $\begin{array}{c}\text { Avg. No. of } \\
\text { Employees/Consulate }\end{array}$ \\
1977 & 91 & $\mathrm{n} / \mathrm{a}$ & 2,020 & $\mathrm{n} / \mathbf{a}$ & 22.2 \\
1981 & 93 & $2.2 \%$ & 2,560 & $26.7 \%$ & 27.5 \\
1989 & 87 & $-6.4 \%$ & 1,950 & $-23.8 \%$ & 22.4 \\
1994 & 92 & $5.7 \%$ & 2,500 & $28.2 \%$ & 27.2 \\
1999 & 99 & $7.6 \%$ & 3,100 & $24.0 \%$ & 31.3 \\
\hline Net Change(1977-1999) & $9.1 \%$ & 1,080 & $55.1 \%$ & 9.1 \\
\hline
\end{tabular}

Source:

(1) Parter, Alan S. Deputy Commissioner (December 1977) The Economic lmpact of the Diplomatic Community on the New York Metropolitan Area. New York City Commission for the United Nations and for the Consular Corps.

(2) New York City Commission for the United Nations and for the Consular Corps (December 1981) The Economic Impact of the Diplomatic Community on the City of New York.

(3) New York City Commission for the United Nations and for the Consular Corps (December 1989) The Economic lmpact of the Diplomatic Community on the City of New York.

As mentioned above, if the foreign consulate community continues to grow at existing levels, approximately 10 new consular uses could establish commercial offices in Manhattan by 2010, and approximately $20 \mathrm{new}$ consulates by 2020 . If existing employment trends continue, it is expected that the employment levels for foreign consulates would increase by approximately 16 percent (500 employees) per decade. Net employment for foreign consulates is expected to be approximately 3,600 employees in 2010 and 4,100 employees in 2020 .

\section{Foreign Consulates Patterns of Space Utilization}

Similar to permanent missions, foreign consulates are extremely diverse and occupy a wide variety of office space. They range in size from approximately $1,000 \mathrm{gsf}$ to more than 100,000 gsf and reside within Class A, Class B, and Class $\mathrm{C}$ offices facilities, as well as within commercial condominium space. Currently, approximately 54 percent of consular offices occupy Class A office facilities in Midtown Manhattan. Foreign 
consular offices are slightly more dispersed throughout much of Manhattan. Unlike most permanent missions, many foreign consulates are located Downtown, central Midtown, and along the West Side of Midtown Manhattan.

Foreign Consulates' Space Utilization-1980-2001

Throughout the last twenty years, foreign consulates have predominantly concentrated within Manhattan Community Boards Five, Six, and Eight (CB5, CB6, CB8). Less than three percent of consulates were located within either CB1 in Downtown Manhattan or along the west side of Midtown Manhattan in CB4, during the 1980 and 1990's. As shown in Table 4-15, most the foreign consulates appear to be moving into CB6 and CB8, and out of CB7 and CB5. From 1980 to 2001, CB6 experienced a 22 percent increase in the amount of commercial office space occupied by foreign consular uses. Most of the newly established foreign consulates have elected to locate their offices in CB6, followed by CB8. Approximately 330,000 gsf of office space in CB6 has been converted into consular offices since 1980.

Table 4-15: Foreign Consulates Referenced by Manhattan Community Board- 1980-2001

\begin{tabular}{|c|c|c|c|c|c|c|}
\hline \multirow{2}{*}{$\begin{array}{l}\text { Manhattan } \\
\text { Community } \\
\text { Board }\end{array}$} & \multicolumn{2}{|c|}{1980} & \multicolumn{2}{|c|}{1988} & \multicolumn{2}{|c|}{2001} \\
\hline & $\begin{array}{c}S F \\
\text { Occupied }^{1}\end{array}$ & $\begin{array}{l}\text { Percent of } \\
\text { Total }\end{array}$ & $\begin{array}{c}S F \\
\text { Occupied }^{2}\end{array}$ & $\frac{\text { Percent of }}{\text { Total }}$ & $\begin{array}{c}S F \\
\text { Occupied }^{3}\end{array}$ & $\begin{array}{c}\text { Percent of } \\
\text { Total }\end{array}$ \\
\hline$C B 6$ & 360,000 & $38 \%$ & 430,000 & $47 \%$ & 690,000 & $60 \%$ \\
\hline$C B I$ & 10,000 & $1 \%$ & 30,000 & $3 \%$ & 20,000 & $2 \%$ \\
\hline CB4 & 20,000 & $2 \%$ & 20,000 & $2 \%$ & 30,000 & $3 \%$ \\
\hline$C B 5$ & 360,000 & $38 \%$ & 300,000 & $32 \%$ & 210,000 & $18 \%$ \\
\hline$C B 7$ & 50,000 & $5 \%$ & 10,000 & $1 \%$ & 0 & $\mathrm{n} / \mathrm{a}$ \\
\hline$C B 8$ & 150,000 & $16 \%$ & 140,000 & $15 \%$ & 200,000 & $17 \%$ \\
\hline Total & 950,000 & $100 \%$ & 930,000 & $100 \%$ & $1,150,000$ & $100 \%$ \\
\hline
\end{tabular}

Estimate of total square feet of commercial space occupied by the 89 foreign consulates is extrapolated from data collected on 36 consular offices in New York City.

Estimate of total square feet of commercial space occupied by the 87 foreign consulates is extrapolated from data collected on 40 consular offices in New York City.

Estimate of total square feet of commercial space occupied by the 99 foreign consulates is extrapolated from data collected on 86 permanent missions in New York City.

The majority of foreign consulates that are located in CB6 have predominantly concentrated in the residential neighborhood of Turtle Bay (see Table 4-16). However, the residential neighborhoods of Murray Hill and Tudor City have also experienced significant increases in the total amount of consular uses since the early 1980 's. During the last 20 years, consular office space within the residential neighborhoods of Murray Hill and Tudor City has more than doubled, while the neighborhood of Turtle Bay has experienced an eleven percent decrease in consular office space utilization. Approximately 54 percent (36 consulates) of foreign consulate office space in CB6 is located in Turtle Bay, and approximately 23 percent (13 consulates) and 15 percent (10 consulates) are located within Murray Hill and Tudor City, respectively. 
The total amount of office space occupied by foreign consulates has increased by approximately 200,000 gross square feet or 21 percent since 1980. Although approximately 75 percent of foreign consulates have relocated to new office facilities during the 1980's and 1990's and some of the larger foreign consulates within Manhattan have constructed or purchased new consulate space, most foreign consulates have experienced little space growth since the 1980's, in spite of the growth in employment (53 percent). The majority of foreign consulates have not expanded significantly and occupy relatively the same amount of space as they did in the early 1980's. The typical or average size of a foreign consulate has fluctuated little and has remained at approximately 11,600 gsf (370 gsf per employee). The average size of typical consulates owned or leased by a foreign government have also remained relatively constant $(9,000 \mathrm{gsf}$ for a leased consular office and 16,000 gsf for a consulate office owned by a foreign government).

\section{Table 4-16: Foreign Consulates in Community Board 6 Referenced by Neighborhood-1980-2001}

\begin{tabular}{|c|c|c|c|c|c|c|}
\hline \multirow[t]{2}{*}{ Neighborhood } & \multicolumn{2}{|c|}{1980} & \multicolumn{2}{|c|}{1988} & \multicolumn{2}{|c|}{2001} \\
\hline & $\begin{array}{c}\underline{S F} \\
\text { Occupied }^{I}\end{array}$ & $\frac{\text { Percent of }}{\text { Total }}$ & $\begin{array}{c}\underline{S F} \\
\text { Occupied }^{2}\end{array}$ & $\begin{array}{l}\text { Percent of } \\
\text { Total }\end{array}$ & $\frac{S F}{\text { Occupied }^{3}}$ & $\frac{\text { Percent of }}{\text { Tatal }}$ \\
\hline Turtle Bay & 235,000 & $65 \%$ & 230,000 & $53 \%$ & 370,000 & $54 \%$ \\
\hline Sutton Place & 0 & $\mathrm{n} / \mathrm{a}$ & 0 & $\mathrm{n} / \mathrm{a}$ & 10,000 & $1 \%$ \\
\hline Murray Hill & 75,000 & $21 \%$ & 80,000 & $19 \%$ & 160,000 & $23 \%$ \\
\hline Kips Bay & 10,000 & $3 \%$ & 20,000 & $5 \%$ & 30,000 & $4 \%$ \\
\hline Tudor City & 30,000 & $8 \%$ & 100,000 & $23 \%$ & 100,000 & $15 \%$ \\
\hline Beekman Place & 10,000 & $3 \%$ & $\underline{0}$ & $\underline{\mathrm{n} / \mathrm{a}}$ & 20,000 & $3 \%$ \\
\hline Total & 360,000 & $100 \%$ & 430,000 & $100 \%$ & 690,000 & $100 \%$ \\
\hline
\end{tabular}

Estimate of total square feet of commercial space occupied by the 89 foreign consulates is extrapolated from data collected on 36 consular offices in New York City.

2 Estimate of total square feet of commercial space occupied by the 87 foreign consulates is extrapolated from data collected on 40 consular offices in New York City.

3 Estimate of total square feet of commercial space occupied by the 99 foreign consulates is extrapolated from data collected on 86 permanent missions in New York City.

As many foreign governments have constructed or purchased commercial office buildings to accommodate both their permanent mission to the UN and their respective foreign consulate office, since the early 1980's, there has been a significant increase in the number of foreign governments that own their respectively consular office. Approximately 37 percent of all foreign consulates own their respective office facilities. As shown in Table 4-17, there has been a 15 percent increase in the total amount of consular office facilities owned by a foreign government since 1980 . Most of these newly constructed or purchased office facilities are relatively small in size (less than 16,000 gsf) and are commercial condominium space in Midtown Manhattan. The majority of consulates (63 percent or 62 consulates), however, continue to occupy leased office facilities. 
Table 4-17: Percentage of Foreign Consulates Owned or Leased by a Foreign Government

\begin{tabular}{ccc}
\hline Year & Percent of Space Leased & Percentage of Space Owned \\
1980 & $78 \%$ & $22 \%$ \\
1988 & $76 \%$ & $24 \%$ \\
1999 & $63 \%$ & $37 \%$ \\
\hline
\end{tabular}

As most foreign consulates were predominantly located in central and eastern Midtown Manhattan during the 1980's and 1990's, most consular uses were concentrated within the three office submarkets that comprise the eastern half of the Midtown North office market. Since the 1980 's, approximately 70 percent of foreign governments have maintained consular offices within the office submarkets of UN Plaza, Plaza, and Grand Central (see Table 4-18). More than 160,000 gsf of office space in the UN Plaza office submarket has been converted into a consular use since the early 1980's. Approximately 80,000 gsf of office space in Grand Central submarket has also been converted into consular uses. In addition, approximately $10,000 \mathrm{gsf}$ of office space in the Upper East Side office market has been converted into consular space. Most of the foreign governments that have had consulate office space in the Midtown South office markets and in the office submarkets along the west side of Manhattan in the early 1980's and 1990's have since relocated their respective offices to the office submarkets of UN Plaza and Grand Central. As of December 2001, approximately 31 percent of foreign consulates were located in the UN Plaza office submarket, and approximately 25 percent and 21 percent were located in the Grand Central and Plaza office submarkets, respectively. Most new foreign consular offices have established consulate facilities in the UN Plaza and Grand Central office submarkets.

As the majority of foreign consulates (approximately 75 percent) have occupied office space in the office submarkets of UN Plaza, Grand Central, and Plaza, most foreign consulates have occupied high-quality Class A office facilities during the 1980's and 1990's. Approximately 54 percent (54) of foreign consulates were located within Class A office facilities in the late 1990's. Less than 18 percent (18) of foreign consulates were located in Class B office facilities and less than 8 percent (8) of were located within Class C facilities. The remaining 20 percent (20) of foreign consulates were located within unclassified office facilities or commercial condominium space.

\section{Forecast of Future Space Utilization Patterns for Foreign Consulates 2010 \& 2020}

Assuming that the utilization trends of foreign consular uses during the last twenty years will continue through the next two decades, the vast majority of the existing and projected foreign consulates are expected to occupy commercial office facilities within Midtown Manhattan. As more than 52 percent of permanent missions do not have consular representation in New York City, the New York City consular community has the potential to expand significantly by 2020 . Although it is very difficult to determine the exact office space needs of individual consulates, as the vary considerably in size, staff levels, and expenditures, the size of a typical or average consulate is expected to remain at approximately $11,600 \mathrm{gsf}$ (approximately $370 \mathrm{gsf}$ per employee). Most of the current consular offices are also expected to occupy the same amount of space and will most likely experience very little growth within the next couple of decades. 
Table 4-18: Foreign Consulates Referenced by Manhattan Office Markets- 1980-2001

\begin{tabular}{|c|c|c|c|c|c|c|}
\hline \multirow{2}{*}{$\begin{array}{l}\text { Manhattan } \\
\text { Office Market }\end{array}$} & \multicolumn{2}{|c|}{1980} & \multicolumn{2}{|c|}{1988} & \multicolumn{2}{|c|}{$\underline{2001}$} \\
\hline & $\begin{array}{c}\text { SE } \\
\text { Occupied }^{I}\end{array}$ & $\begin{array}{c}\text { Percent of } \\
\text { Total }\end{array}$ & $\begin{array}{c}S E \\
\text { Occupied }^{1}\end{array}$ & $\begin{array}{c}\frac{\text { Percent of }}{\text { Total }} \\
\end{array}$ & $\begin{array}{c}\underline{S F} \\
\text { Occupied }^{l}\end{array}$ & $\frac{\text { Percent of }}{\text { Total }}$ \\
\hline UN Plaza & 160,000 & $17 \%$ & 210,000 & $23 \%$ & 320,000 & $28 \%$ \\
\hline Plaza & 320,00 & $34 \%$ & 290,000 & $31 \%$ & 270,000 & $24 \%$ \\
\hline Grand Central & 190,000 & $20 \%$ & 180,000 & $19 \%$ & 270,000 & $24 \%$ \\
\hline UPper E. Side & 140,000 & $15 \%$ & 110,000 & $12 \%$ & 150,000 & $13 \%$ \\
\hline Downtoun & 10,000 & $1 \%$ & 30,000 & $3 \%$ & 20,000 & $2 \%$ \\
\hline Midtown North & 70,000 & $7 \%$ & 60,000 & $7 \%$ & 60,000 & $5 \%$ \\
\hline Murray Hill & 30,000 & $3 \%$ & 40,000 & $4 \%$ & 50,000 & $4 \%$ \\
\hline Gramercy Park & 0 & $\mathrm{n} / \mathrm{a}$ & 0 & $\mathbf{n} / \mathbf{a}$ & 10,000 & $<1 \%$ \\
\hline Midtown South & 10,000 & $1 \%$ & 0 & $\mathrm{n} / \mathrm{a}$ & 0 & $\mathrm{n} / \mathrm{a}$ \\
\hline Upper W. Side & $\underline{20,000}$ & $2 \%$ & 10,000 & $1 \%$ & $\underline{0}$ & $\mathrm{n} / \mathrm{a}$ \\
\hline Total & 950,000 & & 930,000 & & $1,150,000$ & \\
\hline
\end{tabular}

Estimate of total square feet of commercial space occupied by the 89 foreign consulates is extrapolated from data collected on 36 consular offices in New York City.

2 Estimate of total square feet of commercial space occupied by the 87 foreign consulates is extrapolated from data collected on 40 consular offices in New York City.

3 Estimate of total square feet of commercial space occupied by the 99 foreign consulates is extrapolated from data collected on 86 permanent missions in New York City.

If existing trends continue, the Manhattan consulate community can be expected to grow by approximately 10 percent by 2010 , and approximately 20 percent by 2020 . Approximately 10 new foreign consular offices could be established within Manhattan by 2010, and approximately 20 new consular offices by 2020 . In total, the amount of office space occupied by foreign consular offices is expected to increase by approximately 16 percent ( $182,000 \mathrm{gsf})$ by 2010 and by approximately 32 percent (367,000 gsf) by 2020 (see Table 4-19). Based on an expected increase of up to 182,000 gross square feet by 2010 and 367,000 gross square feet by 2020 , the maximum amount of office space occupied by foreign consular uses in Manhattan is expected to be approximately 1.33 million square feet in 2010 , and 1.52 million square feet in 2020.

Table 4-19: Projected Square Feet of New Consular Office Space in Manhattan

\begin{tabular}{lccc}
\hline Year & No. of New Consulates & Tot. SF of New Consular Space & Total SF Occupied by All Consulates \\
2000 to 2010 & 10 & 182,000 & $1,332,000$ \\
2010 to 2020 & 10 & 367,000 & $1,517,000$ \\
\hline & Total Square feet occupied by new foreign consulates is estimated from the average size of a typical consulate leased by \\
a foreign government. & &
\end{tabular}


If existing utilization trends continue, almost all foreign consulates located within $\mathrm{CB} 6$ are expected to maintain their existing commercial office facilities or relocate to similar office facilities within the surrounding area. Although foreign consulates have the freedom to locate anywhere within the City and they are not directly related to the UN, most of the projected foreign consulates are also anticipated to establish commercial office facilities in CB6, followed by CB8. As foreign governments are increasingly establishing their respective consular offices near their respective permanent mission to the UN, many foreign consulates are (re)locating near the UN Headquarters campus in CB6 and in the southern end of CB8. By 2020, if existing growth rates and utilization patterns continue, CB6 would experience a 41 percent ( 26 consulates) increase in the total number of foreign consulates maintaining commercial offices in their community board and CB8 would have an influx of approximately 8 consulates. Over the next 20 years, foreign consular office space in $\mathrm{CB} 1$ and $\mathrm{CB} 4$ is expected to be maintained and up to 417,000 gsf of commercial office space in CB6 and 80,000 gsf of commercial office space in CB8 would be converted into consular space (see Table 4-20). CB5 is anticipated to lose approximately 130,000 gsf of consular office space. Approximately 1.12 million gross square feet of commercial office space in CB6 is expected to be occupied by approximately 89 ( 74 percent of) foreign consulates in 2020.

Table 4-20: Foreign Consulate Space Referenced by Community Board in 2010 \& 2020

\begin{tabular}{|c|c|c|c|c|}
\hline \multirow{2}{*}{$\begin{array}{l}\text { Manhattan } \\
\text { Community } \\
\text { Board }\end{array}$} & \multicolumn{4}{|c|}{2010} \\
\hline & SFOccupied' & Growth in SF & Percent of Tot. & Tot. Percent Change from 2001 \\
\hline CB6 & 892,000 & 202,000 & $67 \%$ & $7 \%$ \\
\hline $\mathrm{CB} 1$ & 20,000 & 0 & $2 \%$ & $0 \%$ \\
\hline CB4 & 30,000 & 0 & $2 \%$ & $-1 \%$ \\
\hline $\mathrm{CB} 5$ & 146,000 & $-64,000$ & $11 \%$ & $-7 \%$ \\
\hline $\mathrm{CB} 8$ & $\underline{244.000}$ & 44,000 & $\underline{18 \%}$ & $1 \%$ \\
\hline Total & $1,332,000$ & 182,000 & $100 \%$ & \\
\hline
\end{tabular}

Estimate of total square feet occupied is based on 10 additional foreign governments establishing foreign consular offices in Manhattan (for a total or 109 consulates) and the average size of a typical consulate owned by a foreign government being approximately $16,000 \mathrm{gsf}$ and the average size of a typical consulate leased by a foreign governument being approximately $9,000 \mathrm{gsf}$. Almost all of the new consular office space is anticipated to be leased space.

\begin{tabular}{l|c|c|c|c}
\hline $\begin{array}{l}\text { Manhattan } \\
\text { Comamunity }\end{array}$ & \multicolumn{3}{|c}{ 2020 } \\
\cline { 2 - 5 } Board & SFOccupied $^{1}$ & Growth in SF & Percent of Tot & Tot. Percent Change from 2001 \\
\hline CB6 & $1,107,000$ & 417,000 & $73 \%$ & $13 \%$ \\
CB1 & 20,000 & 0 & $1 \%$ & $-1 \%$ \\
CB4 & 30,000 & 0 & $2 \%$ & $-1 \%$ \\
CB5 & 80,0000 & $-130,000$ & $5 \%$ & $-12 \%$ \\
CB8 & 280,000 & 80,000 & $18 \%$ & $1 \%$ \\
Total & $1,517,000$ & 367,000 & $100 \%$ & \\
\hline
\end{tabular}

Estimate of total square feet occupied is based on 20 additional foreign governments establishing foreign consular offices in Manhattan (for a total or 119 consulates) and the average size of a typical consulate owned by a foreign government being approximately $16,000 \mathrm{gsf}$ and the average size of a typical consulate leased by a foreign government being approximately $9,000 \mathrm{gsf}$. Almost all of the new consular office space is anticipated to be leased space. 
The majority of foreign consulates in CB6 are expected to occupy commercial office facilities within Turtle Bay in 2010 and 2020. Almost all of the foreign consulates currently located within Turtle Bay are expected to maintain their existing facilities in the Turtle Bay neighborhood and most of the new foreign consulates are expected to locate their office facilities in Turtle Bay. If current trends continue a small percentage of permanent missions will also continue to locate within the predominately residential neighborhoods of Murray Hill and Tudor City.

Foreign governments are also expected to continue to purchase commercial office facilities in Manhattan to serve as consular space. If foreign consulates continue to follow the same tenure trends over the next decade as they did during 1990's, approximately 46 percent of consular uses will own their respective office facilities (a maximum of 55 consulates) by 2020. Although the majority of foreign consulates (54 percent) will continue to occupy leased office facilities, many of the smaller foreign consulates are expected to purchase commercial condominium space in Midtown Manhattan. In total, the number of consular uses owned by a foreign government is expected to increase by approximately 48 percent.

The majority of foreign consulates in 2010 and 2020 are expected to continue to locate in Midtown Manhattan within the office submarkets of Plaza, Grand Central, UN Plaza, and the Upper East Side. Almost all of the foreign consulates located within the UN Plaza, Grand Central, and Upper East Side submarkets are expected to maintain their existing facilities and most of the projected foreign consulates are also expected to located within these submarkets.

\section{v. Conclusions and Recommendations}

Permanent missions, consular uses, the UN Secretariat and the remainder of the UN System are expected to occupy approximately 3.8 to 3.9 million square feet of commercial office space in Manhattan by 2010 and approximately 4.1 to 4.3 million square feet by 2020 , versus 3.7 million square feet of cornmercial office space occupied by the international community today (see Table 4-21). Most of this commercial office space (approximately 52 percent) will be occupied by permanent missions to the UN, followed by foreign consular uses. Although the UN Secretariat will require approximately 800,000 gsf of swing space for its proposed capital refurbishment plan, the UN Secretariat is expected to maintain its zero nominal growth policy over the next twenty years. UNDC is expected to construct a 800,000 gsf office building (along the west side of Robert Moses playground) that will be used as swing space for the UN Secretariat for a period of five years. Once the UN's proposed capital refurbishment is completed, the UN is expected to occupy and retain its swing space. It is anticipated that the UN System would vacate its current office facilities in One and Two UN Plaza, as well as most of its commercial office facilities, and consolidate its office facilities within the proposed UNDC building. As such, the New York City international community is only expected to grow by 347,000 to 527,000 gsf or 9 to 14 percent by 2020 . 
Table 4-21: Existing Conditions and Projected Commercial Office Space Needs of the International Community in Manhattan in 2010 \& 2020

\begin{tabular}{lc}
\hline International Body & SF Occupied in 2000 \\
\hline UN Secretariat & 120,000 \\
UN System & 462,000 \\
Permanent Missions & $2,010,000$ \\
Foreign Consular Uses & $1,150,000$ \\
Total & $3,742,000$ \\
\hline
\end{tabular}

\begin{tabular}{l|c|c|c|c}
\hline \multirow{2}{*}{$\begin{array}{l}\text { International } \\
\text { Body }\end{array}$} & \multicolumn{2}{|c|}{2010} & \multicolumn{2}{c}{2020} \\
\cline { 2 - 5 } & SF Occupied & Growth in SF & SF Occupied & Growth in SF \\
\hline UN Secretariat & 0 & $-120,000^{1}$ & 0 & $-120,000^{1}$ \\
UN System* & $\mathbf{4 6 2 , 0 0 0}$ & 0 & 462,000 & 0 \\
Missions & $2,050,000-2,140,000$ & $40,000-130,000$ & $2,110,000-2,290,000$ & $100,000-280,000$ \\
Consulates & $1,322,000$ & $\underline{182,000}$ & $\underline{1,517,000}$ & $\underline{367,000}$ \\
Total & $3,844,000-3,934,000$ & $102,000-192,000$ & $4,089,000-4,269,000$ & $347,000-527,000$ \\
\hline
\end{tabular}

Excludes the UN Secretariat

After the UN's proposed capital refurbishment is completed, the new UNDC, $800,000 \mathrm{gsf}$ swing space building is expected to be retained by the UN System and used to consolidate many of the UN System's office facilities presently located in One and Two UN Plaza, as well as commercial premises. It is anticipated that the UN Secretariat will no longer occupy any commercial office facilities in 2010 or 2020. 
As mentioned previously, much of the international community prefers to locate near the UN Headquarters campus along the east side of Midtown in CB6 or CB8. If current utilization trends continue, the majority of the projected office space for the international community is expected to be accommodated by office facilities in CB6 and CB8 (see Table 4-22). In addition, some of the existing consular uses in CB5 are anticipated to relocate to CB6 or CB8. Approximately 122,000 to 212,000 gsf of office space in CB6 will be converted into permanent mission or consular-related office space by 2010 , and approximately 397,000 to $577,000 \mathrm{gsf}$ by 2020 . The maximum amount of commercial office space occupied by the UN, permanent missions, and/or foreign consular uses in CB6 is expected to be approximately 3.01 million square feet in 2010, and 3.46 million square feet in 2020 .

\section{Table 4-22: Existing Conditions and Projected Commercial Office Space Needs of the International Community in Manhattan in 2010 \& 2020}

\begin{tabular}{lc}
\hline Community Board & SF Occupied in 2000 \\
CB6 & $2,882,000$ \\
CB8 & 500,000 \\
CB5 & 310,000 \\
CB1 & 20,000 \\
CB4 & 30,0000 \\
Total & $3,742,000$ \\
\hline
\end{tabular}

\begin{tabular}{l|c|c|c|c}
\hline & \multicolumn{2}{|c|}{2010} & \multicolumn{2}{c}{2020} \\
\cline { 2 - 5 } & SF Occupied & Growth in SF & SF Occupied & Growth in SF \\
\hline CB6 & $3,004,000-3,094,000^{*}$ & $122,000-212,000^{*}$ & $3,259,000-3,459,000^{*}$ & $397,000-577,000^{*}$ \\
CB8 & 544,000 & 44,000 & 580,000 & 80,0000 \\
CB5 & 246,000 & $-64,000$ & 180,000 & $-130,000$ \\
CB1 & 20,000 & 0 & 20,000 & 0 \\
CB4 & 30,000 & 0 & 30,000 & 0 \\
Total & $3,884,000-3,934,000$ & $102,000-192,000$ & $4,089,000-4,269,000$ & $347,000-527,000$ \\
\hline
\end{tabular}

Estimate includes a net loss in commercial facilities occupied by the UN Secretariat in 2010 and 2020.

As shown in Table 4-23, there is more than 67 million square feet of commercial office space in CB6, in the office submarkets of UN Plaza, Plaza, Grand Central, Murray Hill, and Gramercy Park. Currently the international community occupies approximately 4.2 percent (approximately 2,882,000 sf) of the entire CB6 commercial real estate market. If the international community continues to maintain its existing growth rate and exhibits similar utilizations trends to the 1980's and 1990 's, the international community can be expected to occupy a maximum of 3.46 million square feet of office space and approximately 5.2 percent of the commercial real estate market in CB6 by 2020. With an increase in international community demand of about 1.0 percent (approximately $577,000 \mathrm{gsf}$ ) of CB6's office space capacity by 2020, it is 
reasonable to expect that office development will readily expand, if necessary, to meet this demand based on market forces alone.

Table 4-23: Available Office Space in CB6

\begin{tabular}{lcccc}
\hline Office Submarket & Total SF & Percent of Market in CB6 & Total SF in CB6 & Tot. SF Avail. in CB6 \\
UN Plaza & $1,800,000$ & $100 \%$ & $1,800,000$ & 150,000 \\
Plaza & $88,000,000$ & $25 \%$ & $21,000,000$ & $1,400,000$ \\
Grand Central & $50,000,000$ & $70 \%$ & $35,000,000$ & $3,200,000$ \\
Murray Hill & $9,000,000$ & $40 \%$ & $3,600,000$ & 210,000 \\
Gramercy Park & $19,000,000$ & $\underline{35 \%}$ & $\underline{6,500,000}$ & $\underline{560,000}$ \\
Total & $167,000,000$ & $\mathrm{n} / a$ & $67,900,000$ & $5,520,000$ \\
\hline
\end{tabular}

Source: GVA Williams Real Estate Corp. (9/27/2001) Market Research Tools. wนw. williamsgva.com

Currently, there is more than 1.5 million square feet of commercial office space under construction in the immediate vicinity of the UN Headquarters campus and seven major potential development sites that could accommodate commercial office development as-of-right under existing zoning regulations near the UN Headquarters campus. In total, approximately 1.11 million square feet of commercial office space could be developed as-of-right near the UN Headquarters which could potentially accommodate UN-related uses, permanent missions, and/or consular uses. The four former Con Edison sites, which are one the largest tracts of undeveloped land (soft-sites) within Manhattan, represent some of the most viable sites for UNrelated uses, permanent missions, and/or consular uses in the future. Located between three to seven blocks from the UN Headquarters, these four properties are in close proximity to the UN Headquarters campus and could potentially accommodate approximately 1.0 million square feet of office/conference space, in a concentrated area, as-of-right under current zoning regulations.

Based on historic trends it is reasonable to assume that office stock in CB6 will expand if necessary to accommodate the international community's future office space demands. Throughout the last twenty years, CB6's office inventory has grown by approximately 13 percent to approximately 67 million square feet. Office space vacancy rates within CB6 and Midtown have fluctuated since 1980, and have remained between 3 and 16 percent. Currently, there is approximately 5.5 million square feet (about 8 percent) of office space available in CB6 that could accommodate permanent missions, consular uses, and UN-related uses. Although there is less than 150,000 square feet of available office space in the immediate vicinity of the UN Headquarters campus in the UN Plaza submarket, there is more than 4 million square feet of available commercial office space in CB6 in the office submarkets surrounding UN Plaza that could accommodate permanent missions, consular uses, and UN-related uses. Space within the small 1.8 million square foot UN Plaza submarket, however, will likely continue to be tight, due to its immediate proximity to the UN. 


\section{APPENDIX A}

Inventors of Irailahle ()ficice space in Manhattan office Markets as of 1 )ecember 2001 


\section{APPENDIX A}

Inventory of Arailable Office Space in Manhattan Office Markets as of I )ecember 2001

\begin{tabular}{|c|c|c|c|c|}
\hline & Total Office Space (SF)* & Avail Oflice Space $(S F)^{*}$ & Percent Available & Average Asking Rent \\
\hline Midtown North & 182.9 & $1+.5$ & $7.94^{\prime \prime} 0$ & $\$ 58.5 t$ \\
\hline Midtown South & 71.0 & 8.0 & 11. ${ }^{7} 7^{\circ}$. & $s+1.1+$ \\
\hline Dountown & 811.? & 6.4 & $8.56^{\circ} \textrm{ }$ & $=1 .+8$ \\
\hline Total & $33+.1$ & 29.4 & 8.800 & $3+6.72$ \\
\hline
\end{tabular}

*hyuate lied are reprosented in nulliom,

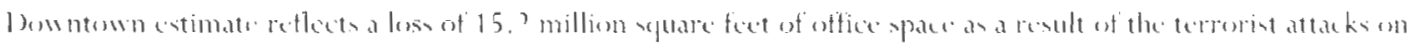

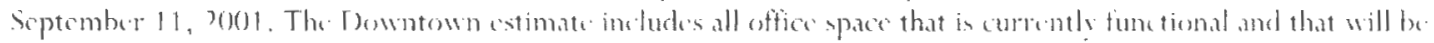
operational by late 2003 or carls 2004.

Wighted arerage anking rent.

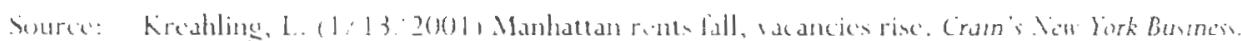




\section{APPENDIX B}

Inventory of . Wailable (ommercial ()tfice Space in Manhattan Communitr Bond 6 


\section{APPENDIX B}

Inventory of Available Commercial Office Space in Manhattan Community Board 6

(Data estimates are from the Second Quarter of 2001 \& reflect office inventories prior to September 11, 2001)

\begin{tabular}{|c|c|c|c|c|c|c|c|c|c|}
\hline \multirow[b]{2}{*}{$\begin{array}{l}\text { Real Estate } \\
\text { Market }\end{array}$} & \multicolumn{4}{|c|}{ Commercial Office Space } & \multicolumn{2}{|c|}{ Class A Office Space } & \multicolumn{3}{|c|}{ Avail. Class A Office Space } \\
\hline & Tot. SF & Tot. SF Avail. & $\%$ Avail. & $\begin{array}{l}\text { Avg. Asking } \\
\text { Rent }\end{array}$ & Tot. SF & $\%$ of Tot & Tot. SF & $\%$ Avail. & $\begin{array}{c}\text { Avg. Asking } \\
\text { Rent }\end{array}$ \\
\hline Manhattan & $349,335,665$ & $28,466,674$ & $8.15 \%$ & $\$ 49.02$ & $207,201,772$ & $59.31 \%$ & $13,137,626$ & $6.34 \%$ & $n / a^{\star}$ \\
\hline Downtown & $95,400,447$ & $7,738,982$ & $8.11 \%$ & $\$ 41.62$ & $53,817,935$ & $56.41 \%$ & $2,694,924$ & $5.01 \%$ & $\$ 46.48$ \\
\hline Midtown N. & $182,915,977$ & $13,587,038$ & $7.43 \%$ & $\$ 64.42$ & $130,964,955$ & $71.60 \%$ & $8,532,422$ & $6.52 \%$ & $\$ 69.27$ \\
\hline Grand Central & $49,695,167$ & $4,606,983$ & $9.27 \%$ & $\$ 60.52$ & $27,638,068$ & $55.61 \%$ & $2,519,540$ & $9.12 \%$ & $\$ 66.74$ \\
\hline Plaza & $87,853,462$ & $5,700,427$ & $6.49 \%$ & $\$ 71.22$ & $73,031,706$ & $83.13 \%$ & $4,323,127$ & $5.92 \%$ & $\$ 72.86$ \\
\hline U.N. Plaza & $1,847,465$ & 151,097 & $8.18 \%$ & $\$ 46.46$ & 785,467 & $16.67 \%$ & 7,524 & $0.96 \%$ & $\$ 60.00$ \\
\hline Midtown S. & $71,019,241$ & $7,140,654$ & $10.05 \%$ & $\$ 42.43$ & $21,418,882$ & $30.16 \%$ & $1,910,282$ & $8.92 \%$ & $\$ 45.69$ \\
\hline Gramercy Park & $19,260,169$ & $1,570,033$ & $8.15 \%$ & $\$ 42.59$ & $6,619,008$ & $34.37 \%$ & 288,138 & $4.35 \%$ & $\$ 43.60$ \\
\hline Murray Hill & $9,285,345$ & 858,088 & $9.24 \%$ & $\$ 41.70$ & $1,842,852$ & $19.85 \%$ & 204,343 & $11.09 \%$ & $\$ 44.71$ \\
\hline
\end{tabular}

\begin{tabular}{|c|c|c|c|c|c|c|c|c|c|c|}
\hline \multirow[b]{2}{*}{$\begin{array}{l}\text { Real Estate } \\
\text { Market }\end{array}$} & \multicolumn{2}{|c|}{ Class B Office Space } & \multicolumn{3}{|c|}{ Avail. Class B Office Space } & \multicolumn{2}{|c|}{ Class C Office Space } & \multicolumn{3}{|c|}{ Ayail, Class C Office Space } \\
\hline & Tot. SF & Tot. SF & Tot. SF & $\%$ Avail. & $\begin{array}{c}\text { Avg. Asking } \\
\text { Rent }\end{array}$ & Tot. SF & Tot. SF & Tot. SF & $\%$ Avail. & $\underset{\text { Rent }}{\text { Avg. Asking }}$ \\
\hline Manhattan & $108,714,177$ & $31.12 \%$ & $11,568,531$ & $10.64 \%$ & $n / a^{*}$ & $34,419,716$ & $9.85 \%$ & $3,760,515$ & $10.93 \%$ & $n / a^{*}$ \\
\hline Downtown & $29,603,961$ & $31.03 \%$ & $3,152,373$ & $10.65 \%$ & $\$ 39.98$ & $11,978,551$ & $12.56 \%$ & $1,891,685$ & $15.79 \%$ & $\$ 37.00$ \\
\hline Midtown $N$. & $44,566,293$ & $24.36 \%$ & $4,442,508$ & $9.97 \%$ & $\$ 59.74$ & $7,384,729$ & $4.04 \%$ & 612,108 & $8.29 \%$ & $\$ 50.26$ \\
\hline Grand Central & $17,866,073$ & $35.95 \%$ & $1,773,838$ & $9.93 \%$ & $\$ 53.92$ & $4,191,026$ & $8.43 \%$ & 313,605 & $7.48 \%$ & $\$ 47.91$ \\
\hline Plaza & $13,958,822$ & $15.89 \%$ & $1,316,708$ & $9.43 \%$ & $\$ 66.19$ & 862,934 & $98.00 \%$ & 60,592 & $7.02 \%$ & $\$ 63.30$ \\
\hline U.N. Plaza & $1,061,998$ & $57.48 \%$ & 143,573 & $13.52 \%$ & $\$ 45.75$ & 0 & $0.00 \%$ & 0 & $0.00 \%$ & $\mathrm{n} / \mathrm{a}$ \\
\hline Midtown S. & $34,543,923$ & $48.64 \%$ & $3,973,650$ & $11.50 \%$ & $\$ 41.74$ & $15,056,436$ & $21.20 \%$ & $1,256,722$ & $8.35 \%$ & $\$ 39.67$ \\
\hline Gramercy Park & $7,612,877$ & $39.53 \%$ & 847,083 & $11.13 \%$ & $\$ 44.04$ & $5,028,284$ & $26.12 \%$ & 434,812 & $8.65 \%$ & $\$ 39.08$ \\
\hline Murray Hill & $5,464,803$ & $58.85 \%$ & 551,417 & $10.09 \%$ & $\$ 41.18$ & $1,977,690$ & $21.30 \%$ & 102,328 & $5.17 \%$ & $\$ 38.47$ \\
\hline
\end{tabular}

* $\mathrm{n} / \mathrm{a}$ : Information is not available.

Source: GVA Williams Real Estate Corp. (9/27/2001) Market Research: Research Tools. www.williamsgra.com 


\section{APPENDIX C}

Summary of Commere ial office space Rented be the UN-Sistem in New Sork Cits 
APPENDIX C

Summary of Commercial Office Space Rented by the UN-System in New York City

\begin{tabular}{|c|c|c|c|c|c|c|c|c|c|}
\hline & Building Address & $\begin{array}{l}\text { UNDCSF } \\
\text { Occupied }\end{array}$ & $\begin{array}{c}\text { Tot. SF } \\
\text { Occupied }\end{array}$ & Cost per SF & $\begin{array}{l}\text { Bldg. } \\
\text { Class }\end{array}$ & $\frac{\text { No, of }}{\text { Stories }}$ & $\begin{array}{c}\text { Office } \\
\text { Submarket }\end{array}$ & $\begin{array}{l}\text { Manhatian } \\
\text { Comm. Board }\end{array}$ & $\frac{\text { CR6 }}{\text { Neighborhood }}$ \\
\hline \multirow{6}{*}{$\begin{array}{l}\text { UN } \\
\text { Secretariat }\end{array}$} & $I U N P T_{Z}$. & 176,126 & 176,126 & $\$ 22.00$ & A & 44 & UN Plaza & $\mathrm{CB} 6$ & Turtlc Bay \\
\hline & $2 U N P l \%$. & 300,000 & 300,000 & $\$ 22.00$ & $A$ & 44 & UN Plaza & CB6 & Turtlc Bay \\
\hline & $30+$ E. $75 \mathrm{St}$ & 0 & 64,527 & $\$ 22.00$ & A & 17 & UX Plaza & C.B6 & Turtlc Bay \\
\hline & 866 UN Pl\%. & 0 & 31,000 & $\$ 46.00$ & $A$ & 40 & UN Playa & CB6 & Turtlc Bay \\
\hline & $8282^{\text {nd }}$ Ave. & 0 & 25,000 & $\$ 34.00$ & $A$ & 21 & UN Plaza & $\mathrm{CB} 6$ & Turtle Bay \\
\hline & Total & 476,126 & 596,653 & & & & & & \\
\hline \multirow[t]{3}{*}{ WNICEF } & $3 U N P L E$. & 180,491 & 180,491 & 532.50 & A & 44 & UX Plaza & CB6 & Turtlc Bay \\
\hline & $6333^{\text {nt }}$ Ave. & 0 & 94,769 & $\$ 27.00$ & A & 41 & Grand Central & CB6 & Murray Hill \\
\hline & Total & 180,491 & 275,260 & & & & & & . \\
\hline \multirow[t]{4}{*}{ UNDP } & I UN Plx. & 162,838 & 162.838 & $\$ 22.00$ & $A$ & 44 & UN Plaza & CB6 & Turtlc Bay \\
\hline & 304 E. 45 St. & 0 & 179,473 & $\$ 22.00$ & $A$ & 17 & UN Plaza & CB6 & Turtle Bay \\
\hline & 336 E. $45^{\text {th }} \mathrm{St}$ & & 20,335 & $\$ 22.00$ & B & 15 & U.V Plaza & CB6 & Turtle Bay \\
\hline & Total & 162,838 & 362,646 & & & & & & \\
\hline \multirow{3}{*}{$\begin{array}{l}\text { UNFPA } \\
\text { UNOPS }\end{array}$} & 220 E. $425 \pi$ & 0 & 91,000 & 376.00 & $n / a^{2}$ & 37 & Grand Central & $\mathrm{CB} 6$ & Murray Hill \\
\hline & 405 Lexington Ave. & 0 & 76,000 & $\$ 43.00$ & A & 77 & Grand Central & CB6 & Murray Hill \\
\hline & Total & $\mathbf{n} / \mathbf{a}$ & 168,000 & & & & & & \\
\hline Overall Total & & 819,455 & $1,402,600$ & & & & & & \\
\hline
\end{tabular}

Source: Inited Nations Office of Facilities Monagement, August 200)! 
APPENDIX D

Arailable (office Ypace in the Vicinity of the United Nations 


\section{APPENDIX D}

\section{Available Office Space in the Vicinity of the United Nations}

\begin{tabular}{|c|c|c|c|}
\hline Office Building & Tot. SF Avail. & Avg. Asking Rent & Building Description \\
\hline 16003 Ave. & 14,464 & negotiable & Class $\mathrm{A}, 42$-stories, 1.0 million rsf \\
\hline 26053 Ave. & 156,569 & $\$ 58 / \mathrm{sf}$ & Class $A, 43$-stories, 1.4 million rsf \\
\hline 36223 Ave. & 92,138 & $\$ 45$ to $\$ 59 / \mathrm{sf}$ & Class $\mathrm{A}, 39$-stories, 1.0 million rsf \\
\hline 46303 Ave. & 28,376 & $\$ 36$ to $\$ 48 /$ sf & Class $\mathrm{A}, 23$-stories, 1.0 million rsf \\
\hline 56333 Ave. & 96,500 & negotiable & Class $\mathrm{A}, 41$-stories, 1.0 million rsf \\
\hline 66553 Ave. & 33,244 & $\$ 35$ to $\$ 60 / \mathrm{sf}$ & Class A, 28-stories, $0.6 \mathrm{rsf}$ \\
\hline 76663 Ave. & 65,544 & $\$ 58$ to $\$ 70 / \mathrm{sf}$ & Class $\mathrm{A}, 32$-stories, 0.7 million rsf \\
\hline 86753 Ave. & 45,291 & $\$ 58 / \mathrm{sf}$ & Class A, 31-stories, $0.6 \mathrm{rsf}$ \\
\hline 96853 Ave. & 154,770 & $\$ 40$ to $\$ 65 / \mathrm{sf}$ & Class A, 27-stories, 0.3 million rsf \\
\hline 107083 Ave. & 50,545 & $\$ 47$ to $\$ 53 / \mathrm{sf}$ & Class A, 35-stories, 0.6 million rsf \\
\hline 117113 Ave & 23,173 & $\$ 48$ to $\$ 55 /$ sf & Class $\mathrm{A}, 19$-stories, 0.8 million rsf \\
\hline 127333 Ave. & 9,220 & negotiable & Class $\mathrm{A}, 23$-stories, 0.5 million rsf \\
\hline 137473 Ave. & 50,002 & $\$ 52$ to $\$ 59 /$ sf & Class A, 38-stories \\
\hline 14205 Lex. Ave. & 20,054 & $\$ 37 / s f$ & 18-stories, 0.1 million rsf \\
\hline 15215 Lex. Ave. & 32,735 & $\$ 37$ to $\$ 40 / \mathrm{sf}$ & Not Available \\
\hline 16353 Lex. Ave. & 4,100 & $\$ 39$ to $\$ 45 / \mathrm{sf}$ & 15-stories, 71,000 rsf \\
\hline 17355 Lex. Ave & 7,120 & $\$ 39$ to $\$ 45 / \mathrm{sf}$ & Class A, 22-stories, 0.3 million rsf \\
\hline 18360 Lex. Ave. & 26,378 & negotiable & Class A, 24-stories, 0.3 million rsf \\
\hline 19369 Lex. Ave. & 23,198 & $\$ 41$ to $\$ 50 / \mathrm{sf}$ & Class A, 26-stories, 0.3 million rsf \\
\hline 20370 Lex. Ave. & 25,358 & $\$ 32$ to $\$ 46 /$ sf & Class A, 26-stories, 0.4 million rsf \\
\hline 21405 Lex. Ave. & 181,242 & $\$ 67$ to $\$ 89 / \mathrm{sf}$ & Class A, 77-stories, 1.2 million rsf \\
\hline 22441 Lex. Ave. & 37,439 & $\$ 52$ to $\$ 64 / \mathrm{sf}$ & 18-stories, 0.1 million rsf \\
\hline $23823 \mathrm{UN} \mathrm{Plz}$. & 5,055 & negotiable & Class B, 11 -stories, 0.2 million rsf \\
\hline 24866 UN Plz. & 7,887 & negotiable & Class A, 40 -stories, 0.3 million rsf \\
\hline 258002 Ave. & 55,000 & negotiable & Class A, 18-stories \\
\hline 268012 Ave. & 19,350 & negotiable & Class A, 22-stories, 0.2 million rsf \\
\hline 278662 Ave. & 10,000 & $\$ 53$ to $\$ 57 / \mathrm{sf}$ & Class A, 15-stories, $90,000 \mathrm{rsf}$ \\
\hline 288852 Ave. & 29,324 & $\$ 48 / \mathrm{sf}$ & Class $\mathrm{A}, 49$-stories, 1.0 million rsf \\
\hline 29261 Madison Ave. & 32,460 & $\$ 40$ to $\$ 42 / \mathrm{sf}$ & Class $\mathrm{A}, 30$-stories, 0.6 million rsf \\
\hline 30269 Madison Ave. & 5,744 & $\$ 36$ to $\$ 40 / \mathrm{sf}$ & 21 -stories, 0.1 million rsf \\
\hline 31275 Madison Ave. & 30,684 & $\$ 40$ to $\$ 51 / \mathrm{sf}$ & Class A, 42-stories, 0.5 million rsf \\
\hline 32295 Madison Ave. & 61,165 & $\$ 44$ to $\$ 48 / \mathrm{sf}$ & Class A, 45 -stories, 0.4 million rsf \\
\hline 3390 Park Ave. & 205,897 & $\$ 45$ to $\$ 60 / \mathrm{sf}$ & Class $\mathrm{A}, 81$-stories, 2.0 million rsf \\
\hline 3499 Park Ave. & 82,802 & negotiable & 25 -stories, $29,800 \mathrm{rsf}$ \\
\hline 35100 Park Ave. & 56,821 & negotiable & Class $\mathrm{A}, 36$-stories, 1.6 million rsf \\
\hline 36101 Park Ave & 103,370 & $\$ 75$ to $\$ 80 / \mathrm{sf}$ & Class A, 46-stories, 0.7 million rsf \\
\hline 37125 Park Ave & 54,695 & $\$ 52$ to $\$ 67 /$ sf & Class A, 24-stories, 0.6 million rsf \\
\hline 38205 E. $42 \mathrm{St}$. & 1,276 & negotiable & Class A, 20-stories, 0.7 million rsf \\
\hline 39220 E. $42 \mathrm{St}$. & 24,992 & $\$ 55 / \mathrm{sf}$ & Class A, 37-stories, $65,000 \mathrm{rsf}$ \\
\hline 40222 E. 41 St. & 166,446 & $\$ 65 / \mathrm{sf}$ & Not Available \\
\hline $41 \quad 124$ E. $40 \mathrm{St}$. & 4,900 & $\$ 27$ to $\$ 38 / \mathrm{sf}$ & 11 -stories, $49,000 \mathrm{rsf}$. \\
\hline 42202 E. 35 St. & 3,000 & negotiable & Not Available \\
\hline $43 \quad 314$ E. 34 St. & 14,000 & negotiable & Class B, 6-stories, $10,800 \mathrm{rsf}$ \\
\hline Total & $2,152,000$ & & \\
\hline
\end{tabular}

Source: Costar, Dec. 2001, Avail. office sp. in the submarkets of UN Plaza, Grand Central, \& Murray 